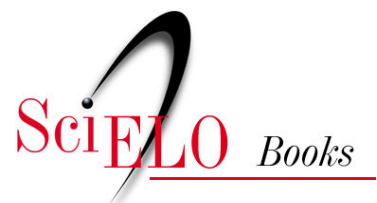

\title{
Um aprendiz de ciência
}

\author{
Carlos Chagas Filho
}

CHAGAS FILHO, C. Um aprendiz de ciência. Rio de Janeiro: Nova Fronteira; Rio de Janeiro: Editora FIOCRUZ, 2000. 279 p. ISBN 85-209-1082-3. Available from SciELO Books <http://books.scielo.org>.

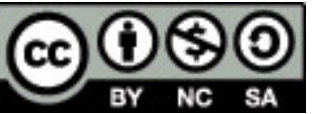

All the contents of this work, except where otherwise noted, is licensed under a Creative Commons Attribution-Non Commercial-ShareAlike 3.0 Unported.

Todo o conteúdo deste trabalho, exceto quando houver ressalva, é publicado sob a licença Creative Commons Atribuição Uso Não Comercial - Partilha nos Mesmos Termos 3.0 Não adaptada.

Todo el contenido de esta obra, excepto donde se indique lo contrario, está bajo licencia de la licencia Creative Commons Reconocimento-NoComercial-CompartirIgual 3.0 Unported. 


\section{Carlos Chagas Filho}

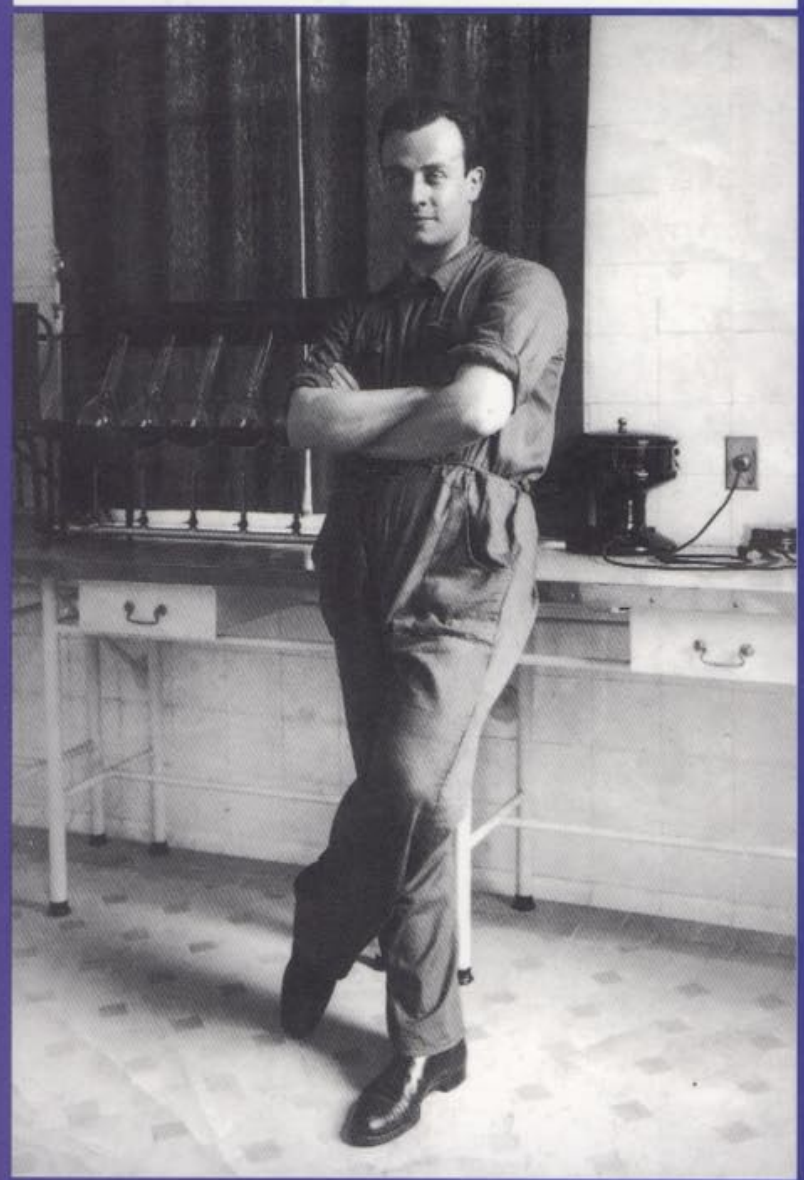

Um Aprendiz

\section{de Ciência}
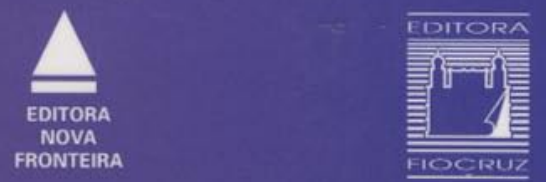


\section{Um aprendiz de ciência}


FUNDAÇ̃̃O OSWALDO CRUZ Presidente

Eloi de Souza Garcia

Vice-Presidente de Ambiente, Comunicação e Informação

Maria Cerilia de Souza Minayo

\section{EDITORA FIOCRUZ}

Rua Leopoldo Bulhões, 1480

Térreo, Manguinhos - CEP 21041-210

Rio de Janeiro - RJ - Brasil

Tels.: (21) 598-2701 e 598-2702

Telefax: (21) 598-2509 e 598-2700

E-mail: revedit@fiocruz.bre

amello@netflash.com.br

Coordenadora

Maria Cectlia de Souza Minayo

Conselho Editorial

Carlos E. A. Coimbra Jr.

Carolina M. Bori

Charles Pessanha

Hooman Momen

Jaime L. Benchimol

José da Rocha Carvalheiro

Luiz Femando Femeira

Miriam Struchiner

Paulo Amarante

Paulo Gadelha

Paulo Marchioni Buss

Vanize Macedo

Zigman Brener

Coordenador Executivo

Joäo Carlos Canossa P. Mendes
EDITORA NOVA FRONTEIRA S.A.

Rua Bambina, 25 - Botafogo - 22251-050

Rio de Janeiro - RJ - Brasil

Tel.: (21) 537-8770 - Fax: (21) 286-6755

http://www.novafronteira.com.br

E-mail: novafr2@embratel.net.br

Equipe de Produção

Leila Name

Regina Marques

Michelle Chao

Izabel Aleixo

Sofia Sousa e Silva

Marcio Araujo 
Carlos Chagas Filho

\section{Um aprendiz de ciência}

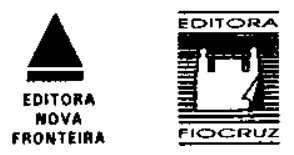


Copyright 2000 Casa de Oswaldo Cruz / Fiocruz

Todos os direitos reservados desta edição reservados à

FUNDAÇÃO OSWALDO CRUZ/EDITORA

EDITORA NOVA FRONTEIRA

\section{Fotos}

Com exceção de referências indicadas nas legendas, as fotos do caderno "Retratos" pertencem ao acervo particular de Anna Leopoldina de Mello Franco Chagas e ao fundo Familia Chagas do Departamento de Arquivo

e Documentação da Casa de Oswaldo Cruz/Fiocruz.

Coordenação executiva e preparação de originais

Paulo Gadelha

Revisão

Eduardo Monteiro

Shahira Mahmud A. Daoud

Mario Luis Grangeia

Índice onomástico

Isabel Grau

Projeto gráfico e tratamento de imagens

Femando Vasconcelos

CIP-Brasil. Catalogação-na-fonte

Sindicato Nacional dos Editores de Livros, RJ.

C424a Chagas Filho, Carlos, 1910-2000

Um aprendiz de ciência / Carlos Chagas Filho. - Rio de Janeiro : Nova Fronteira : Ed. da Fiocruz, 2000

ISBN 85-209-1082-3

1. Chagas Filho, Carlos, 1910-2000 - Biografia. 2. Cientistas - Brasil - Biografia. 3. Ciência - Brasil - História. I. Título. 
Para Annah 



\section{Sumário}

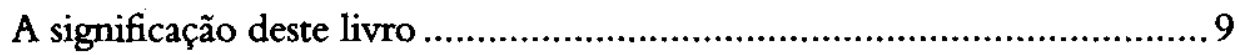

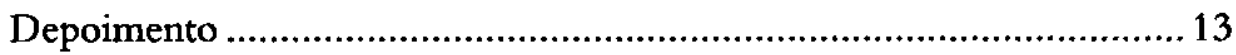

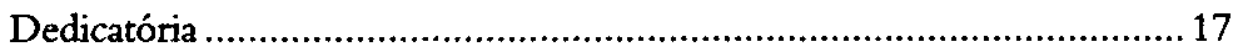

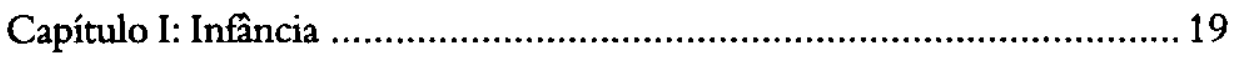

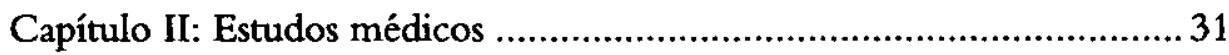

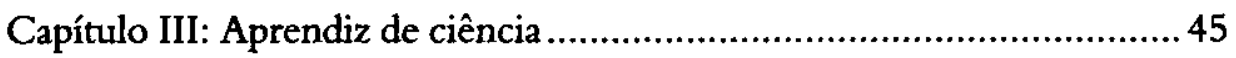

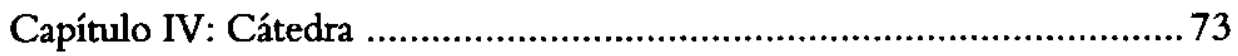

Capítulo V: Instituto de Biofisica Carlos Chagas Filho ............................93

Capítulo VI: Direção da Faculdade de Medicina ................................... 139

Capítulo VII: Ciência e cultura: criação do CNPq,

Conferências das Nações Unidas e Embaixada do Brasil na Unesco ....... 145

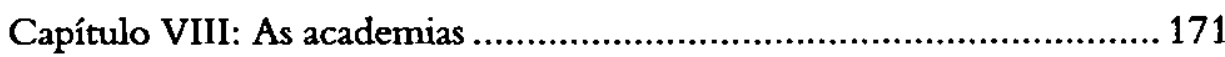

Capítulo IX: Lembranças afetivas: viagens, carnaval e Annah ................ 189

Capítulo X: Concentração, alegria e otimismo …………………......... 197

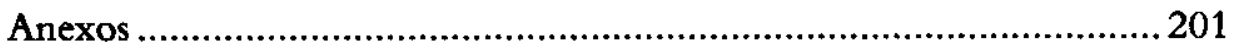

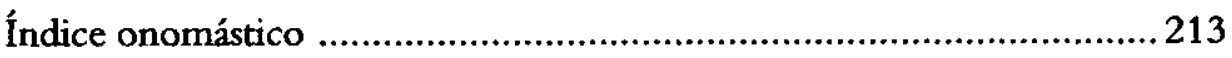





\title{
$A$ significação deste livro
}

\author{
Josué Montello
}

A denominar a si mesmo um aprendiz de ciência, no título deste seu de uma obra autobiográfica, no enunciado de seu título, deve realçar os próprios méritos com um traço de modéstia, já que é ele, no texto evocativo, a personagem central.

Um dos grandes mestres do período clássico português, dom Francisco Manoel de Melo, associou a condição de aprendiz à nobreza lusitana, e daí a peça que, no entender de outro mestre, Teófilo Braga, teria inspirado, em parte, o teatro de Molière: $O$ fidalgo aprendiz.

O aprendiz, no caso de Carlos Chagas Filho, teria, assim, uma conotação superior, própria da condição humana, se não estivesse associado, no campo específico, à própria condição de todos aqueles que, por força da vocação $\mathrm{e}$ da aplicação especializada, souberam ajustar o pendor pessoal ao tirocínio da própria vida.

Diz-nos o velho Domingos Vieira, no seu copioso Tesouro da língua portuguesa, que, na corte de dom João IV, para ser elevado à condição de fidalgo aprendiz, era preciso saber "danças e bailados novos, como a galharda e a pavanada".

Nosso Carlos Chagas Filho, se buscou na condição de aprendiz de ciência o abrigo de sua própria natureza, acertou na expressão adequada, ao reconhecer que a ciência, como domínio do saber especializado, implica necessariamente a preparação gradativa, de que emerge, com a plenitude do 
saber, o cientista completo, seguindo o caminho que o levaria à glória dos nomes internacionais. Que outros se contentassem com o saber individual, no campo restrito das experiências pessoais.

Carlos Chagas Filho, mais do que o cientista que se limita ao renome restrito, cioso de seu próprio saber, fechado em si mesmo, fez-se o mestre de gerações sucessivas, e com isto continua a preparar, à revelia da idade e das limitações que o tempo impõe a todos nós, outros cientistas, outros mestres, com o mesmo empenho. Direi mesmo: com idêntica devoção.

Quem consulta o Anuário da Academia Brasileira, relativo ao período compreendido entre 1993 e 1997, pode constatar esta evidência: aos seis livros publicados por Carlos Chagas Filho, entre 1973 e 1989, correspondem as vinte e três publicações que vieram a lume sob os cuidados de seu estímulo e a responsabilidade de seu renome internacional.

A mais recente dessas publicações, Science for Development in a Solidarity Framework, sob a chancela da Academia Pontificia de Ciência, então presidida por nosso patrício, em Roma, diz bem de seu desempenho no plano político superior.

Mais do que um puro homem de ciência, no campo de suas especialidades, é ele, hoje, com o seu saber, com as suas glórias, com a sua devoção às grandes causas do mundo contemporâneo, um benemérito da humanidade.

Certa vez, em Paris, convidado para assistir a uma de suas conferências, fui ao endereço indicado, no cair da tarde. Realizava-se ali, em sala próxima, outra conferência, e havia uma multidão que enchia os corredores, estendendo-se para outras dependências do prédio.

Pensei, de mim para mim, que se tratava dos audientes do outro conferencista, enquanto ia pedindo licença, degrau a degrau, para tentar alcançar o local em que ouviria Carlos Chagas Filho. E tive esta surpresa confortadora: toda aquela multidão estava ali, não para ouvir o outro orador, e sim atraída por nosso patrício.

Senhor da língua alheia, e mestre de sua ciência, Carlos Chagas Filho estava ali como estaria no Rio de Janeiro, ou em São Paulo, ou em outro ponto de sua pátria, com o mesmo saber, a mesma fluência, a mesma visão objetiva da ciência contemporânea, dando a nós, seus patrícios e seus admiradores, a oportunidade de nos orgulharmos dele, mais uma vez, como testemunhas de sua glória. 
Apresentado por Maurice Druon, em Paris, na Academia Francesa, a Louis de Broglie, ouvi do famoso criador da mecânica ondulatória as mais altas referências a Carlos Chagas Filho, nosso antigo embaixador junto à Unesco. Bem mais tarde, quando me coube ser um de seus sucessores no mesmo posto, recolhi, com o meu orgulho de brasileiro, e de seu confrade na Casa de Machado de Assis, as mais desvanecedoras alusões ao seu saber e ao seu prestígio, como um dos líderes da instituição, enquanto representou ali o nosso país. Não foi apenas um diplomata, com seu tato e sua experiência, na sucessão, ali, de outro mestre: Paulo Carneiro. Foi ele próprio individualizado por sua personalidade inconfundivel.

$\mathrm{O}$ duque de Broglie, num de seus últimos livros, Certitudes et incertitudes de la science, em 5 de julho de 1963, em Paris, teve a oportunidade de reconhecer, com a claridade de seu saber e de suas experiências, que as aplicações da ciência contemporânea iriam proporcionar a todas as sociedades humanas as iniciativas mais importantes, correspondentes a dois séculos de conquistas aceleradas. $\mathrm{E}$ acrescentamos: a que ele próprio, com seu saber e a sua imaginação, iria associar as conquistas que o levariam ao Prêmio Nobel.

E é ainda o mesmo duque de Broglie, no prefácio ao livro de um mestre do jornalismo em língua francesa, Luc Durtain, Les grands figures de la science franfaise, quem reconhece que "evocar as grandes figuras dos grandes sábios é um dos modos mais vivos e mais ajustados à realidade histórica para que sigamos, ao longo das idades sucessivas, o progresso das ciências".

Carlos Chagas Filho, ajustando-se pessoalmente à compreensão da ciência contemporânea, legou-nos duas obras imperecíveis: primeiro aquela em que recompôs o itinerário científico de Carlos Chagas, seu pai, a quem deveu, além da própria vida, o exemplo supremo que fez de seu filho uma das figuras patrimoniais da ciência brasileira, e agora, como remate provisório (porque há de ter continuação), a lição suprema de suas próprias experiências, ao longo de toda uma vida benemérita, reunidas neste volume.

Mais do que um livro evocativo, Um aprendiz de ciência, na obra de Carlos Chagas Filho, é bem uma síntese autobiográfica, com a qual, à maneira de Jean-Jacques Rousseau, no prefácio de Les confessions, irá comparecer diante de Deus, daqui a muitos anos. 



\title{
Depoimento
}

\author{
Paulo de Góes Filho
}

$\mathrm{O}$

$s$ laços que me ligam ao professor Carlos Chagas Filho são antigos e permaneceram estreitos ao longo de toda a minha vida. Ao me solicitar este depoimento, acredito que o professor Chagas tenha pensado no trabalho que realizei para minha dissertação de mestrado em antropologia social, no Museu Nacional, e que versou sobre o instituto que hoje leva seu nome.

Para mim, a figura de Carlos Chagas Filho parecia incorporar todos os atributos que definiam o "tipo ideal" de cientista, sendo freqüente a prática de consultá-lo ou convocá-lo para "representar" a comunidade em ocasiões em que se desejava homenageá-la, como, por exemplo, no episódio de comemoração dos trinta anos do CNPq, em 1981.

A escolha do Instituto de Biofisica Carlos Chagas Filho, da Universidade Federal do Rio de Janeiro, foi fruto, por sua vez, de uma série de fatores, alguns ligados a minha própria biografia, outros relacionados à facilidade de acesso à instituição e aos informantes. Por essa razão, no processo de construção de meu objeto precisei dedicar um considerável esforço de "desnaturalização" e de "dessubstancialização". Esta era a contribuição que poderia fazer a partir de meu trabalho antropológico para resgatar o trabalho de uma vida que mudou a ciência brasileira, sem cair no elogio fácil e no discurso consagrador. Meu depoimento é, portanto, fruto de um trabalho que, se confirmou toda a minha admiração por Carlos Chagas Filho, não tem aí seu ponto de partida. 
Foi no decorrer de uma longa pesquisa que fui progressivamente percebendo a grande diversidade e complexidade do Instituto de Biofisica, a riqueza da trajetória de seus pesquisadores, a multiplicidade das interseções com outros segmentos da sociedade, a criatividade das invenções de Chagas, sua presença na criação do campo científico no Brasil, ou seja, um conjunto de fatores que a tornavam uma instituição singular.

O Instituto de Biofísica mantém nos últimos cinqüenta anos uma incontestável posição de liderança na maior parte dos movimentos (a criação do Conselho Nacional de Pesquisas, em 1951, a reforma universitária e a instituição de pós-graduação no Brasil, entre outros) que permitiram que o campo científico ganhasse autonomia no Brasil e que a produção e a reprodução acadêmicas obtivessem amplo reconhecimento social.

O principal papel do instituto foi o de mobilizar apoios, governamentais e não-governamentais, vencer resistências internas e externas dentro do espaço em que deveria legitimar-se e sobretudo, por intermédio de seu fundador, o professor Carlos Chagas Filho, criar categorias que hoje constituem tradições da ciência brasileira, mas que nem sempre estiveram ali.

Numerosos princípios que aparecen hoje como naturais aos cientistas brasileiros são, na verdade, o resultado de hábeis criações do professor Chagas. Entre estes assomam como mais significativos aqueles que tornaram indissociáveis o ensino e a pesquisa, impuseram a "necessidade" de se criar uma ciência "nacional" de "padrão internacional" e separaram a produção científica de sua utilidade imediata, transformando a "qualidade" e a "excelência" da produção nos únicos critérios legítimos de reconhecimento.

Ao longo de minha pesquisa para dissertação de mestrado, que intitulei $O$ Brasil no biotério: o Instituto de Biofisica Carlos Chagas Filho e o jeito brasileiro de fazer ciência, pude perceber numerosas estratégias inovadoras que foram fruto da dedicação e da inteligência desse pesquisador exemplar.

Transcendendo as regras aparentemente rígidas do "mundo da ciência" pude constatar, no caso estudado, como puderam ser incorporados a esse espaço outros "estilos de vida" percebidos aos olhos do senso comum como pertencentes a dimensões da "cultura" brasileira estranhas ao campo científico.

Hoje, são recorrentes as representações que associam à "comunidade científica" uma única forma legítima de aquisição de prestígio, fundada em critérios objetivos de qualidade e competência. 
Entretanto, as relações entre o corpo de pesquisadores do IBCCF e os mais diversos segmentos da sociedade brasileira, particularmente suas elites, foram um traço marcante para a caracterização do grupo que ao longo dos anos integrou o instituto. Entretanto, imputar exclusivamente a esta associação o prestígio do instituto seria uma interpretação ingênua. A estratégia foi inversa: foram os investimentos ali realizados na incorporação ao Brasil das regras que se consagravam internacionalmente, e que pouco a pouco tornavam o campo científico uma dimensão privilegiada do mundo internacional, que deram a essa instituição seu caráter singular.

Essas estratégias de conversão ao mundo da ciência de distintos tipos de capital, a par do prestígio científico pessoal do professor Chagas, resultaram no que hoje é a ciência brasileira no que tem de melhor.

O equilibrio resultante do uso discriminado, nos momentos apropriados, de distintos tipos de capital através daquelas estratégias que se mostrassem potencialmente mais eficazes foi fundamental, tanto na gênese quanto na consolidação da instituição. $O$ professor Chagas, em inúmeras situações, usou de seu prestígio e de sua rede de relações para trazer ao mundo da ciência apoios e recursos que sem seu empenho, e muitas vezes sacrificio pessoal, jamais ali chegariam. E não foi só o instituto que se beneficiou dessa atitude. Durante a década de setenta a Academia Brasileira de Ciências, por exemplo, sobreviveu graças a uma dotação do governo federal que o professor Chagas obteve em troca da aceitação do cargo de embaixador junto à Unesco.

O êxito do instituto não resultou "naturalmente" e "exclusivamente" da adoção por seu fundador de uma "fórmula" racionalmente preconcebida ou foi a conseqüência de um projeto integralmente articulado. Na verdade, foi a permanente avaliação e percepção das condições sociais que se apresentaram em cada conjuntura específica que orientou as decisões tomadas por Carlos Chagas Filho, gerando as condições de possibilidade para que o processo de conversão dos vários tipos de capital ao campo científico se realizasse com êxito.

O outro conjunto de questões que pautou meu trabalho teve como referência a dimensão "nacional" dessa experiência, sobretudo na medida em que a aquisição de prestígio no campo científico é fortemente influenciada por representações que atribuem, tanto no "discurso científico", quanto no "discurso nativo" sobre a ciência, a precedência do caráter "universal" e 
"supranacional" do conhecimento científico sobre seu caráter local e nacional. A articulação entre essas duas dimensões, pude perceber, pelo menos na tradição brasileira, implicou significativos investimentos na valorização de um terceiro espaço, a interseção entre duas dimensões - nacional e internacional. Nesse sentido, a valorização por Chagas do "intercâmbio" e a importância dos postos internacionais em sua trajetória revelaram como foi central esse papel na reconfiguração das fronteiras do "mundo da ciência".

Com base nessas observações sobre o Instituto de Biofisica e sobre os estilos de vida de seus pesquisadores, é possível supor que a "ciência" feita ali se impôs, ao longo dos anos, como modelo, tornando-se paradigma do "jeito brasileiro de fazer pesquisa".

Foi por meio desses princípios que se tornou possível criar as bases para o reconhecimento de uma ciência nacional baseada na utilização de modelos autóctones.

Nas palavras do próprio professor Chagas:

Foi por isso que escolhi como modelo de trabalho o peixe-elétrico. Se não tivesse sido o peixe, o modelo que eu escolheria seria a preguiça. Não sei quando, mas certamente bem no começo de meu trabalho, é que surgiu esse tipo de orientação, que cada vez mais se enraíza em mim, de que nos países subdesenvolvidos devemos usar as técnicas mais avançadas em modelos autóctones...

É essa lição que devemos manter viva para que possamos manter vivo o exemplo do professor Carlos Chagas Filho. 


\section{Dedicatória}

Tão é fácil escrever a sua própria biografia. A tendência natural é 1 contar só os fatos positivos e os momentos felizes, deixando de lado todas as dificuldades que permeiam o caminho de cada um. Certamente, foi com esse espírito que escrevi Um aprendiz de ciência.

Em verdade, minha vida transcorreu sem grandes tropeços e sem maiores obstáculos. É claro que tive para me ajudar o nome ilustre de meu pai, que me abriu portas, me facilitou transpor oceanos e foi maravilhoso indicador do caminho que desejei seguir.

Quero sublinhar o que devo a minha mulher, Annah, sem cuja compreensão, incentivo e companheirismo eu nada teria feito.

Tive, também, no momento em que comecei a crescer, a inestimável ajuda de Guilherme Guinle.

Desejo, ainda, assinalar o auxálio que me foi prestado por Werther Duque Estrada Bastos, que me ensinou a dissecar o poraquê, o que deu origem à linha principal de meus trabalhos, e por Marcelo Damy de Souza Santos, que me mostrou como lidar com substâncias radioativas e preparou, para a minha utilização, o contador de Geiger-Müller, com o qual realizei as minhas primeiras pesquisas sobre a fosforilação no órgão elétrico, em colaboração com Moura Gonçalves.

Muitos outros colegas do Instituto de Biofisica e da universidade, aos quais agradeço, fizeram, também, com que minha vida científica fosse e eu aqui tiro a imagem de uma frase de Prigogine - o desenrolar de uma 
grande estória, na qual a Sherazade foi o desejo de contribuir para a ciência brasileira.

Quero citar, especialmente, o nome de José Carneiro Felippe, que me indicou brilhantemente as trilhas que me levaram à compreensão, ainda que modesta, dos meandros da fisica moderna, e o de René Wurmser, admirável mestre que me mostrou os caminhos da biologia moderna.

A todos eles dedico este livro, o qual não teria sido possível não fosse Lêda Serrano do Carmo, que, com extraordinária dedicação e minúcia, deu-me o necessário apoio nesta empreitada.

Dedico, também, esta biografia ao Instituto de Manguinhos, onde se formou a minha vontade de ser cientista. Os exemplos que ali perscrutei deram-me o modelo que procurei seguir e permitiram-me formular uma série de perspectivas no campo do desenvolvimento científico e de sua implementação. Foram eles fundamentais para a criação do Instituto de Biofisica.

À estrela d'alva, que tantas vezes iluminou o caminho que me levava de Manguinhos à estaçãozinha da estrada de ferro e que continua, poeticamente, a iluminar meus passos.

Agradeço, ainda, a Anna Margarida Chagas Bovet a colaboração dada na revisão deste livro, e ao meu amigo Darcy Fontoura de Almeida a leitura e a correção que fez destas páginas.

Um agradecimento especial a Paulo Gadelha, que muito me estimulou a publicar a pequena estória de minha vida, e aos funcionários da Casa de Oswaldo Cruz que se ocuparam da publicação do livro. 


\section{I}

\section{Infância}

$\mathrm{O}$

Rio de Janeiro onde nasci, em 1910, e passei a minha infância e adolescência era, então, uma cidade deliciosamente calma, sem o tumulto que hoje tanto nos preocupa. Assim é que, já nos anos trinta, quando comecei a minha vida profissional, ia, em menos de quarenta minutos, de minha casa na rua Paissandu até a estação da Leopoldina, onde tomava o trem para o Instituto Oswaldo Cruz. Primeiro, seguia no ônibus da linha Guanabara-Clube Naval, onde se fazia a baldeação para a linha Clube Naval-Leopoldina. Tomava lugar, em geral, no andar superior, pois os ônibus desta linha tinham dois andares, como os de Londres, de onde a concessionária Light \& Power os havia importado. Era uma cidade tranqüila o nosso Rio, assim como era tranqüila a vida das crianças e dos adolescentes de então. As festas infantis eram raras e eu só me lembro de ir à casa do marechal Souza Aguiar, nosso vizinho na rua Paissandu, $e$ às reuniões nas casas de meus primos, especialmente dos que moravam na rua Marquês de São Vicente. Nas idas a Copacabana, raríssimas, tomava-se o bonde que, lenta mas eficazmente, nos transportava para o bairro que, na época, era quase um subúrbio. Passava-se pelo Túnel Novo. Ipanema era mais longe e o bonde atravessava o Túnel Velho. Ia-se, uma vez por ano, à casa de uma prima de minha mãe. Fazíamos uma espécie de piquenique e, no fim da tarde, permitiamme molhar os pés nas águas, as mais das vezes muito frias - assim delas me lembro -, do mar. A casa ficava na esquina ainda não delineada da atual Farme de Amoedo. Raras eram as residências ao longo da praia e só em parte separadas da areia pelo asfalto da avenida, hoje a Vieira Souto. 
Meus dias começavam cedo. Meu pai vinha me acordar já recendendo a cigarro. Logo depois surgia a Fräulein Elza Dingues, minha governanta alemã, e, em seguida, eu ia ver minha mãe. Logo que podia, desvencilhavame da Fräulein e ia brincar com minha imaginação, no pomar, saltando de árvore em árvore, de jamelão a abacateiro, tentando imitar as façanhas de um herói épico que encontrava nas páginas do folhetim Coração Leal. Tentava, como ele, proteger os índios da perseguição sanguinária dos brancos invasores. Creio que essa fantasia infantil foi a semente de muitas das lutas que travei mais tarde.

Meu irmão Evandro, cinco anos mais velho, foi, desde o princípio, objeto da minha maior admiração. Mas eu o via pouco, pois ele saía de casa muito cedo, a princípio para ir ao colégio, e, com o passar do tempo, à faculdade ou ao hospital. Meu único companheiro de divertimentos era o Diomedes, filho da Maria, a simpática cozinheira de meus avós Fernando e Maria Lobo. Era um garoto forte, um pouco mais velho do que eu, mas sempre disposto a me acompanhar nas travessuras e a ser meu "pau-mandado". Depois que crescemos, perdi-o de vista completamente, até que um dia, pelos anos quarenta, vim a encontrá-lo em frente ao cinema Guanabara. Lá estávamos, vários amigos, entre os quais Occhialini, Vinicius de Moraes, Plínio Sussekind da Rocha e Otávio Faria, para assistir a uma fita considerada verdadeira obra de arte pelos grandes cinéfilos da época, todos contrários ao cinema falado, opinião da qual eu não partilhava. Essa fita deveria ser uma obra-prima, se levássemos em conta a grande maioria dos filmes norte-americanos, únicos que aqui chegavam, e que, em sua maior parte, cantavam as glórias das armadas ianques na região do Pacífico; desenhavam, ainda, uma imagem irreal da vida universitária norte-americana, e nada tinham a ver com a sucessão do grande filme de David Griffith $O$ nascimento de uma nasão. Aproximei-me do Diomedes, então, e como o achei extremamente alcoolizado, disse-lhe: "O que é isso, Diomedes?" Olhou-me com um olhar muito vago e fez a seguinte reflexão: "Oh! Gente, eu que sou o fisionomista, e o senhor é que está me reconhecendo!" Alguns dias depois, apareceu no meu escritório no antigo edificio da Faculdade de Medicina, na Praia Vermelha. Não sei como descobriu o meu endereço, mas queria me ver para pedir desculpas pelo estado em que eu o encontrara. Estava admiravelmente bem vestido, e vendo que eu apreciava o seu trajar, disse-me: "Eu vou me regenerar porque agora me amiguei com 
a costureira que tem um ateliê na rua da Passagem." Vinha me visitar constantemente e contou-me que, na sua ascensão social, tirara a mãe das atividades domésticas. Assim foi por muitos anos, com periodicidades várias, mas sempre bem trajado e dizendo que estava trabalhando com eficiência. Mais ou menos cinco anos depois deixou de aparecer. De vez em quando sua imagem me vinha à mente na lembrança de uma passagem infantil, ou na semelhança com um preto que eu via na rua. Um dia apareceu-me uma senhora modesta. Pedindo desculpas por me perturbar, vinha informar-me de que era a viúva do Diomedes - com quem se casara no civil e no religioso -, morto num desastre de trânsito na Cidade Nova. Lembro-me de como meu coração se confrangeu: era mais uma etapa da minha vida infantil que desaparecia. Perturbou-me, por muito tempo, a idéia de que eu não dera ao Diomedes a atenção e o auxílio que nossa amizade exigia.

Quando comecei a freqüentar o colégio, era a Fräulein que me preparava para a caminhada que fazia da rua Paissandu à rua Soares Cabral. Nos dois primeiros dias, duas coisas me preocuparam. A primeira, a presença da governanta, pois já me achava grande demais para ter que sair à rua acompanhado. A segunda, a mochila nos ombros, na qual eram colocados os meus livros e a merenda. Desusada na época, chamava a atenção de todos os que me viam no longo trajeto: rua Paissandu, rua Ipiranga, rua do Rozo hoje Coelho Neto - , rua Guanabara, que ainda não se chamava Pinheiro Machado, Álvaro Chaves e parte da rua Soares Cabral.

Lembro-me da primeira vez que entrei no Curso Lyra. Fui levado, imediatamente, à presença da diretora: dona Hermínia Lyra da Silva. Dona Hermínia era uma grande dama: a voz suave deixava seu interlocutor à vontade; o fino perfil e o cabelo grisalho davam-lhe o feitio de um medalhão antigo, mas o que transparecia de sua pessoa era uma expressão de bondade que nunca esquecerei. Fiquei rubro de vergonha e mal sabia o que dizer. Dona Hermínia chamou um veterano, Antônio Ferreira Jacobina, para ser o meu guia. Levou-me ao pequeno recreio, onde conheci os meus primeiros amigos: Carlos Alberto Rocha Faria, Arthur Pizzarro, Álvaro Nunes Pereira e Mário Van Erven. Graças à intermediação de Antônio Jacobina, fui recebido de braços abertos e integrado à "turma". Alguns dias mais tarde, sentados na beira da calçada, fui informado por eles dos mistérios da vida, que me eram totalmente desconhecidos. 
A volta do colégio era diferente. Saía com Carlos Alberto Rocha Faria, passávamos pelo Fluminense, que ainda não tinha construído o seu estádio, e tomávamos a rua Paissandu na sua embocadura, em frente ao Palácio Guanabara. Vínhamos sempre pelo lado ímpar, passando pelo campo de futebol do Clube de Regatas do Flamengo e, em seguida, pelo portão do Clube de Tênis Paissandu, reduto dos funcionários britânicos da Light, e, logo depois, o grande jardim que circundava a casa de José Carlos Rodrigues, alugada para residência do embaixador da França. Cem metros adiante, parávamos na quitanda do seu Antônio, onde comprávamos deliciosas mariolas, que já se perderam na memória de muitos cariocas. Ali, Carlos Alberto e eu nos separávamos: seguia ele para a rua Senador Vergueiro, onde morava, e eu atravessava a rua, o que na época não oferecia perigo, para entrar no número 148 da Paissandu, que, como descrevi no livro $\mathrm{Meu}$ pai, era uma casa de dois andares construída no meio de um jardim, no fundo do qual um frondoso pomar permitia saborear mangas, abacates, jamelões e outras frutas brasileiras. De um dos lados, uma longa e agradável varanda onde as plantas e as orquídeas, em seus xaxins, todas tão do agrado de minha mãe, competiam, na alegria de suas cores, com os ornados ladrilhos de fabricação portuguesa que decoravam o piso. Entre a casa e o pomar, uma grande área cimentada, que me permitia, primeiro, andar de velocípede, depois, de bicicleta e, por fim, treinar tênis enviando a bola à parede da larga cozinha onde dois fogões de lenha facilitavam a minha mãe exercer maravilhosamente sua atividade culinária. Nossa casa foi visitada por inúmeros cientistas estrangeiros que, na vinda ao Rio, não dispensavam a visita a meu pai, que lhes oferecia sempre um almoço apetitoso na ampla sala de jantar.

O ensino no Curso Lyra era excelente, ministrado, sobretudo, pelas sobrinhas de dona Hermínia, uma das quais dona Minote - naquele tempo os alunos ainda não chamavam as professoras de "tia" - , a quem eu recorria nas horas dificeis por que passam os alunos que, muitas vezes, não têm tempo de preparar suas lições. Fui um bom aluno, mesmo porque a Fräulein me ensinara disciplina mental quando me alfabetizara, tarefa não exercida por minha mãe, que ainda não se refizera da gravíssima gripe espanhola que a acometera. As aulas que mais me fascinavam eram as de canto, nas quais interpretávamos as canções infantis francesas, o que me facilitou, enormemente, o aprendizado dessa língua. Essas aulas me possibilitaram, alguns 
meses depois, e com a ajuda de um dicionário, a leitura do livro da condessa de Ségur Jean qui grogne et Jean qui rit, no seu texto original. Com que esforço! Eu estava preparado para tais empreendimentos porque a Fräulein já me fizera ler e traduzir do alemão, minha primeira língua, o livro de Goethe $O$ sofrimento do jovem Werther. Foram duas duras experiências que me permitiram mais tarde, na estada no Colégio Rezende, fazer a análise lógica da Confederação dos Tamoios.

No Curso Lyra havia uma aula de história natural na qual se falava de plantas e bichos, da natureza, enfim. Talvez tenha sido esta a minha primeira iniciação às ciências, completada pela minha longa permanência, de manhã cedinho, no pomar da casa da rua Paissandu, onde aprendi a conhecer, num diálogo solitário com a natureza, as plantas, o verde e os pequenos animais que por lá passavam.

Do Curso Lyra fui para o ginásio no Colégio Rezende, uma das grandes instituições de ensino secundário do Rio de Janeiro. Dava-se ao ensino, nessa casa, a maior atenção, e a qualidade do mesmo seguia os moldes do que se fazia no Colégio Pedro II.

Aquele contato inicial com a natureza veio a ser reforçado com a minha primeira estada no campo, numa pequena fazenda em Sobragi, perto de Juiz de Fora. Sobragi era um sonho de calmaria e beleza campestre. Nosso passeio principal era ir à beira do Paraibuna para tentarmos fisgar um lambari - tarefa dificil nas águas um tanto revoltas da região. Desse modo, à grande alegria na pesca de um peixe se juntava aquela de ver a passagem dos comboios na linha férrea situada na outra margem do rio.

Era o sítio propriedade de meu tio Otávio Barbosa Carneiro, casado com Aurora, irmã de minha mãe. Otávio Carneiro aparece-me, cada vez mais, como um homem excepcional. Magro, alto, com um pequeno cavanhaque, tinha no olhar uma extrema suavidade, que podia mascarar a sua extraordinária força de vontade. Era um positivista ortodoxo e, durante muito tempo, freqüientador do Templo da Humanidade. Amigo de Teixeira Mendes, nem por um momento deixou de lado a ortodoxia do seu pensamento comtiano, demonstrando, entretanto, uma grande compreensão pelos que não partilhavam de suas idéias. Assim é que permitiu que seus sete filhos fossem batizados, seguindo os desejos de minha tia Aurora. Foi neutra, também, a sua posição de combate a alguns dos seus companheiros de fé religiosa à 
vacinação obrigatória, tanto no tempo de Oswaldo Cruz como no de meu pai. Empreendedor, começou sua vida trabalhando, sob a direção de Trajano de Medeiros, nas oficinas de construção de vagões para a Estrada de Ferro Central do Brasil, e foi, mais tarde, o responsável pela construção do primeiro grande arranha-céu da cidade, o edificio do jornal $A$ Noite, no início da avenida Rio Branco.

Coube-lhe organizar a companhia de navegação do São Francisco e uma usina termoelétrica, fornecedora de eletricidade para a cidade de Pirapora. A Viação São Francisco mantinha dois barcos que faziam, regularmente, a viagem entre Pirapora e Juazeiro, na Bahia. Verificando os trabalhos da companhia, Otávio Carneiro fez, um dia, uma viagem a Juazeiro. Na volta, adoeceu gravemente. Astrogildo Machado, seu concunhado, seguiu para Pirapora na tentativa de salvá-lo. Tudo em vão.

Trazido para o Rio, Otávio Carneiro teve um sepultamento extraordinariamente comovente, o qual seguiu, exatamente, as normas da religião da Humanidade. Seu corpo, velado em sua casa da rua Marquês de São Vicente, 300, dela saiu ao som da "Ave-Maria" de Gounod. Nunca esquecerei a emoção que tive vendo desaparecer um grande homem e assistindo ao desespero dos amigos e de meus primos e primas, ainda todos pequenos. Sua última lembrança para mim foi o envio, na véspera da minha formatura, de um volume: Conseil aux médecins, escrito por Audifret. Livro comtista, nada sectário, tendo sido escrito antes da era pasteuriana.

Otávio Carneiro sentia em si a necessidade do progresso. A fazenda de Sobragi, tentativa onerosa, tinha como finalidade principal a adaptação do gado holandês, leiteiro por excelência, às condições climáticas brasileiras, resultando num aumento de produção de leite. Meu tio queria, também, tentar a criação do cavalo percherão, extremamente útil para o transporte de cargas. Ainda mais, desejou utilizar Sobragi para a criação de pôneis, muito populares na Argentina, e de grande utilidade nas pequenas propriedades. Para realizar os seus ideais, Otávio Carneiro trouxe para Sobragi, como capataz, o peão argentino Palamoni, que salvou minha vida em um episódio cuja lembrança até hoje me faz estremecer. É que, para me ensinar a andar a cavalo, amarrou-me à sela encilhada em um pequeno pônei. Este, sob o comando do capataz, começou a andar calmamente. De súbito, porém, a barrigueira cedeu, a sela rodou e eis-me de cabeça para baixo, amarrado ao cavalo! Até hoje 
tremo ao pensar na sensação que então senti. Salvou-me a extraordinária força do argentino que, com um murro na testa do animal, o fez parar por instantes, o que deu tempo para que me desvencilhassem da situação em que me encontrava.

O idealismo de Otávio Carneiro estendeu-se, ainda, ao desejo de criar grandes plantações de mamona, com o fim de obter óleos vegetais que pudessem servir de combustivel. O retorno de Sobragi era sempre tristonho. Deixava a liberdade - ainda que supervisada, de longe, por minha tia Aurora, pelos capatazes e pela Nica, ama de meus primos - para a vida regrada da rua Paissandu e do Colégio Rezende.

Foi no Colégio Rezende que eu aprendi, realmente, a disciplina do estudar, o que fez desabrochar e fortalecer o meu espírito. Para lá seguia, pela manhã, em torno das nove e quinze, no bonde da linha Humaitá-Largo do Machado, que dez minutos depois me deixava na rua Bambina, onde ficava o colégio. Voltava para casa mais ou menos às cinco horas da tarde, mas o tempo ali passado era magnificamente aproveitado. Tínhamos aulas com professores de grande nomeada, como João Ribeiro e Silva Ramos, de história geral e português, respectivamente, e com professores mais jovens, dois dos quais marcaram muito a minha formação: Ruy Fioravanti, mais tarde professor do Pedro II, e Paulo Gama, que deixou o colégio para ser promotor numa cidade de Minas Gerais. Eram moços de grande instrução e repetidores da matéria dada pelos professores titulares, entre os quais dona Silvia Rezende e o professor Niemeyer, com quem tive aulas de latim durante três anos.

Algumas considerações devem ser feitas. A primeira, relativa ao cuidado com que era ensinado o português, com aulas de gramática e análise lógica diárias. Silva Ramos vinha às quintas-feiras e discutia conosco a qualidade de nossas redações, ora feitas sobre um tema por ele recomendado, ora de livre escolha. Na sua prosódia portuguesa, corrigia-nos o estilo e, quando necessário, os erros gramaticais. $O$ ensino era admirável, feito numa grande intimidade com o notável mestre que, um dia, deu a seguinte resposta a um estudante mais petulante que lhe perguntara quando iria nos ensinar gramática: "Gramática, meu caro menino, não se ensina, aprende-se!"

Éramos quatorze alunos, entre os quais se distinguiam: Maria Eugenia Serra, que, logo depois de formada, tirou o primeiro lugar no concurso para funcionário do Banco do Brasil; Marina Moscoso, que conseguiu realizar uma 
brilhante carreira no Itamarati; Reinaldo e Alberto Cruz Santos, grandes companheiros; Horácio de Carvalho, o de maior distinção entre nós todos e que residia numa linda mansão em frente ao colégio; Fernando Gusmão Lobo, o mais brilhante da turma; Higas Chagas Pereira, o mais popular, pois era um bom futebolista, chegando a jogar no primeiro time do Flamengo como meia-esquerda - denominação da época -; e Silvia Vaccani, tão bonita quanto excelente aluna de matemática.

A segunda consideração que desejo fazer é que não havia provas parceladas e, para obtermos os doze certificados de exames preparatórios necessários à matrícula na universidade, tínhamos que prestar exames no Colégio Pedro II, onde as bancas eram amedrontadoras para os alunos estranhos à instituição. Íamos cedo para a rua Larga, onde fazíamos os exames escritos. A seguir, duas horas de intervalo, que podiam ser gastas no cinema "poeira", cujo proprietário nos deixava entrar sem que tivéssemos que pagar o bilhete inteiro. Depois do almoço, tinham início as provas orais, que se prolongavam, muitas vezes, até às tantas, findo o que um inspetor vinha colocar, no quadro da entrada, o resultado da média dos dois exames, sendo quatro o grau mínimo de aprovação. No entanto, a seriedade dos exames era, certamente, a mola - a "virada" - que nos fazia estudar ao chegar o fim do ano.

No colégio a vida era muito agradável. Dois recreios de meia hora pareciam-nos curtos demais, porém, na grande maioria, tínhamos tanto interesse pelo estudo que voltávamos às pressas, interrompendo, muitas vezes pela metade, a pelada que estávamos jogando. Uma das nossas maiores distrações era espreitar a casa vizinha. Tínhamos sido informados de que nela morava uma senhora lindíssima, que aqui fixara residência depois da passagem de uma trupe de teatro. Ficávamos um grande tempo do recreio olhando por cima do muro para ver se a vislumbrávamos. Isto nunca aconteceu. $\mathrm{O}$ mais que chegamos a ver foi o seu cachorrinho de estimação. Muitos anos mais tarde, vim a conhecer a senhora Champlinska, pois assim se chamava nossa vizinha, num baile de fim de Carnaval no Palace Hotel. Vi-me, subitamente, dançando com uma gordinha simpática de cabelos ruivos. Não sei por que perguntei-lhe se era ela a Champlinska. Perguntou-me como eu a tinha reconhecido. Disse-lhe que tinha sido uma inspiração e que, durante anos, eu a havia espreitado por cima do muro do colégio, mas que só agora conseguia vê-la, o que lhe provocou uma gargalhada. 
Saíamos do colégio sem tumulto, cada um para o seu lado. Não havia a confusão que hoje vemos a porta de quase todos os colégios, produzida pelo amontoado de automóveis que vão buscar os alunos, ou então, dos ônibus que levam as crianças de volta às suas residências.

Fiz os "preparatórios" em quatro anos, sendo o exame de português sempre o mais dificil. As matemáticas eram divididas em três anos: no primeiro, aritmética; no segundo, álgebra; e no terceiro, geometria e trigonometria. Isto nos permitia um estudo muito mais tranqüilo do que aquele que se faz hoje, com o sistema de círculos que se repetem com raios de maior extensão. O que sei é que nós, secundaristas, saíamos do colégio muito bem preparados para enfrentar o exame vestibular na universidade. Não me consta a existência, na época, dos "cursinhos", hoje espalhados por toda a cidade.

Nossas férias eram bianuais: as de São João e de São Pedro, que duravam uma semana, e as grandes férias de verão. Além disso, numerosos feriados, muitos dos quais desapareceram do calendário escolar, como o 14 de julho, Dia da Tomada da Bastilha, e o 19 de novembro, Dia da Bandeira. Essas constantes interrupções não nos prejudicavam porque a recuperação era rápida, pois que passávamos quase todo o dia no colégio. Estudávamos, também, à noite, quando nossa atenção não era absorvida, como hoje em dia, pelos canais de televisão. Para a grande parte dos estudantes, quase todos de classe média, aquela era uma etapa importante da vida.

No Colégio Rezende, uma boa porcentagem de alunos tinha situação econômica diversa. Dona Marieta Rezende, sua diretora e administradora, de elevadas qualidades, estabelecera critérios diferentes para a cobrança das mensalidades, pagas de acordo com a situação financeira de cada família. Desse modo, havia muitos que freqüientavam o colégio gratuitamente. Dona Marieta, prima distante de minha mãe e irmã de Leonidas Rezende, com sua mentalidade progressista e inovadora, queria estender a todos os beneficios de uma educação acima da média. Tínhamos por ela um grande respeito e, também, medo, quando convocados à sua sala. Esse medo, no entanto, se dissipava, pois, apontando os erros que havíamos cometido, Marieta Rezende - fazia sem provocar humilhações e com um carinho quase maternal. Até hoje me admiro com o fato do nome de Marieta Rezende não ter sido consagrado pelas autoridades educativas do Rio de Janeiro para a denominação de um colégio público, tal a qualidade que caracterizou a vida dessa professora. 
$\mathrm{O}$ ambiente do Colégio Rezende, onde tive as primeiras aulas de fisica e química, foi, sem dúvida, um fator de extraordinário progresso para o menino da rua Paissandu.

Foi durante o curso secundário que passei a gozar as férias de verão na Fazenda da Tartária, perto de Oliveira. Na primeira vez fui acompanhando minha avó Mariana Cândida e ali demoramos alguns dias. Depois, seguimos para Oliveira. Há, dessa viagem, um episódio curioso. Ali chegando, vovó Mariana resolveu que eu deveria fazer a primeira comunhão, pois encontravase residindo na casa-grande - que havia sido de meu bisavô e, na ocasião, pertencia a tio Henrique - monsenhor Aureliano Mourão, que batizara meu pai. Tive que confessar pela primeira vez. Aguardei numa salinha contígua àquela em que monsenhor Aureliano estava confessando os penitentes. Como monsenhor era muito surdo, os penitentes tinham que referir os seus pecados em voz altíssima, com o que completei a "formação" que se havia iniciado na calçada da rua Soares Cabral...

Na Tartária e em Oliveira, onde tinha a grande liberdade de visitar meus tios e com eles me entreter, foi que eu realmente aprendi a conviver com as gentes e conhecer a hospitalidade do povo brasileiro. Transcrevo, aqui, uma carta que me foi enviada por minha prima Francisca Vivas de Castro, de quinze anos, bisneta de meu tio Henrique, por ocasião das comemorações, em Oliveira, do $90^{\circ}$ aniversário da descoberta da doença de Chagas:

Caros primos professor Carlos Chagas e dona Annah:

Como no tempo de seu bisavô, professor Carlos Chagas, também hoje a Tartária se preparou para receber tão ilustres hóspedes. Assim como antigamente, foram acesos os fornos, achas de lenha foram trazidas do mato, secadas e rachadas para que o fogão lançasse suas chamas nos fundos de nossas panelas e os quitutes e quitandas estivessem fresquinhos e deliciosos à mesa de nossos visitantes. Tudo isto faz parte da centenária tradição mineira de hospedagem. As toalhas foram tiradas dos baús, lavadas e engomadas, perfumadas com alfazema e capim-de-cheiro. O café foi torrado e moído, os ovos foram colhidos fresquinhos, o fubá moído no velho "moinho d'água". Licores e doces foram feitos das mais saborosas frutas do pomar. As vassouras vasculharam cada canto do velho casarão e nenhum grão de poeira ficou a salvo. Até nossas flores e 
plantas receberam rega especial. Tudo para que jamais a tradição de boa hospedeira deixasse de existir na Tartária.

O casarão ainda é o mesmo de sua infância, caro professor; mais envelhecido em sua estrutura física, de difícil conservação, mas sob seu telhado colonial, no abrigo de suas velhas paredes o mesmo calor humano de gerações descendentes de capitão Carlos. Nosso velho assoalho de tábuas largas e centenárias ainda conserva o som dos passos fortes do capitão Carlos, de meu bisavô, seu tio Henrique e de meu avô Leopoldo, do andar macio de sua avó Mariana, o ruído dos pezinhos a correr do menino Carlos Chagas e os passos educados da criança carioca, os seus passos, professor Carlos Chagas Filho.

O célebre e eterno "mingau da Tartária" ainda é servido à nossa mesa, feito do leite fresquinho de nossas vacas, tirado pelos nossos retireiros. Tudo igual e tão diferente: não mais os velhos lampiões e lamparinas, não mais os carros de bois e os cavalos. Tudo muda, só não pode mudar o coração dos homens. Neste deverá haver sempre os sentimentos de hospitalidade, de respeito e temor a Deus, de reverência e saudade aos nossos antepassados, de garra para enfrentar o futuro.

Seguindo talvez os seus passos e os de seu pai, Carlos Chagas, meus dois irmãos Leopoldo e Max estão estudando medicina. Meus pais lutam para manter a velha Tartária de pé, para fazê-la produtiva e auto-sustentável, o que não tem sido fácil. Papai na lida diária do fazendeiro e Mamãe tentando disfarçar na casa, as velhas manchas do tempo com flores, paninhos de crochê e tantos mimos mais. Esta é a nossa vida, queridos professor e dona Annah. Ainda ouvimos de nossos empregados a velha saudação: "Vamos apiá, a casa é de vanceis"; nossos morros e colinas ainda estão "lá em riba"; nossos passarinhos ciscam no terreiro e, pela manhã e tarde, trinam em nossas velhas mangueiras e jaboticabeiras. O "João de Barro" continua fazendo sua casinha, mantendo a entrada de costas para a chuva.

Tudo igual, só os homens mudam...

Hoje a Tartária revive seus dias de glória. Já cedinho nossas portas e janelas se abriram à brisa suave de nossos campos, e os raios mornos do sol de inverno aqueceram todos os aposentos para que, quando vocês chegassem, nossas paredes emanassem o mesmo calor que há tantas gerações aquece o velho casarão. 
Bem-vindos à nossa Casa, queridos professor e dona Annah, que este momento não seja apenas um momento de saudade, mas sim a certeza de que as velhas tradições mineiras aqui ainda estão preservadas. Que as almas daqueles que nos precederam e iniciaram a história da família Castro, muitas vezes alegre, outras vezes dolorosa, estejam hoje na Paz do Senhor Deus e que Ele lhes permita verem, nem que seja por um breve instante, a alegria deste momento.

Como representante da última geração dos Castro, sinto-me orgulhosa em saudá-los.

Que esta seja a primeira mas não sua última visita à nossa Casa e que a proteção de Deus esteja sempre com vocês.

Francisca Vivas de Castro

A religiosidade de meus parentes, aliada à beleza das procissões da Semana Santa e das visitas aos cruzeiros - implantados sempre num ponto alto das fazendas - começou também a penetrar na minha alma e me fez pensar na existência do além do cotidiano da Terra. Nessas longas caminhadas, muitas vezes comecei a meditar sobre a beleza que trazem ao homem suas crenças e suas esperanças, coisa que existe até hoje como componente essencial de minha alma. 


\section{II}

\section{Estudos médicos}

M inhas últimas férias em Oliveira foram no início de 1926. Dali fui chamado por meu pai, pois deveria prestar exames para a Faculdade de Medicina do Rio de Janeiro. Meu pai percebera que, com a Reforma Rocha Vaz, o programa do mesmo se tomara muito mais complexo, e temia que eu não estivesse bem preparado. Eu deveria, pelo menos, rever alguns pontos da matéria, principalmente aqueles relativos à fisica e à química. Ingenuamente, eu achava que o que sabia era suficiente e, nos quinze dias que faltavam para o exame, só aceitei receber, de Paulo Cameiro, umas aulas de química. Foi o que me salvou, pois as perguntas com que tive que lidar, na prova escrita e na oral, eram muito mais dificeis do que eu pensara, e a matéria mais complexa do que a que eu aprendera para os exames do Pedro II. Na Reforma Rocha Vaz, que então se implantava, as várias matérias do exame vestibular não eram mais feitas em uma só banca, mas sim em bancas separadas de fisica, química e história natural. Nas provas escritas, com exceção da de química - graças aos ensinamentos de Paulo Cameiro -, não me saí bem. Assim mesmo consegui classificar-me em $87^{\circ}$ lugar, numa turma de pouco mais de duzentos alunos.

Matriculado na faculdade, minha primeira e grande preocupação foi escapar dos primários e lamentáveis trotes com que os veteranos se divertiam à custa dos calouros. Lembro-me, até hoje, da gritaria de alguns alunos mais velhos procurando "o filho do Carlos Chagas", enquanto estava eu escondido num desvão do anfiteatro de fisica, ajudado pelo Magalhães, velho funcionário da Praia Vermelha. 
Iniciado o curso começou o desapontamento. Os professores, embora competentes, limitavam-se a permanecer no edificio da Praia Vermelha pouco além do tempo despendido nas aulas, o que restringia o contato com os alunos. Exceção seja feita ao ensino de anatomia, professada no Instituto Anatômico, na rua Santa Luzia. Embora o material cadavérico para as aulas oficiais fosse relativamente escasso, aquele cedido às aulas dos livres-docentes era, no entanto, abundante; de qualquer modo, podia-se trabalhar com facilidade e dissecar à vontade. Já na cadeira de biologia e parasitologia, que também fazia parte do currículo do primeiro ano, havia apenas dois microscópios, e tínhamos que formar, com graves inconveniências, filas enormes para observarmos, por somente alguns momentos, uma preparação. Em compensação, o professor titular da mesma disciplina, Pacheco Leão, na sua bonomia e grande capacidade didática, era uma atração para nós todos. Diretor do Jardim Botânico, onde residia, recebia-me com freqüência, às tardes, para percorrermos juntos parte do grande parque vegetal. Tal convivência foi importante porque supriu, em muito, as falhas do meu conhecimento biológico. Encantador no falar, Pacheco Leão fascinava-me, ainda, com as estórias que me contava sobre a Bacia Amazônica, que bem conhecera em companhia de meu pai.

Outro curso que nos animava, no segundo ano, era o de histologia: a abundância de microscópios, quase individuais, e de cortes histológicos, fazianos sentir mais perto dos objetivos que nos haviam levado à Faculdade de Medicina. Penso que, enquanto alguns dentre nós tinham uma verdadeira vocação para a medicina clínica, era eu mais fascinado pelos microscópios e pela observação do funcionamento de tecidos e órgãos. Foi a falta de uma faculdade de ciências no Rio de Janeiro e no Brasil o que me levou à escolha da Faculdade de Medicina.

A permanência na faculdade era muito agradável. Seu amplo pátio nos permitia uma convivência alegre, muitas vezes chistosa, com os colegas, e o café, na saída dos fundos, era outro ponto de reunião. Além do mais, freqüientemente jogávamos uma pelada no saguão de entrada, interrompida pela chegada do Magalhães, que, com o porteiro João Pedro, formava a dupla de nossos guardiães e, ao mesmo tempo, protetores e vigilantes da integridade da casa. Fiz, nesse período, grandes amizades, entre as quais cito, apenas, Almir Castro, Walter Oswaldo Cruz, Emmanuel Dias, Haroldo de Freitas e Tito 
Enéas Leme Lopes. Alguns destes me acompanharam pelo resto da vida e, nas minhas lembranças, se confundem com outros como Lozir Vianna, Eudoro Villela, Joaquim de Oliveira Neto e Pedro Nava, que tanto a enriqueceram. Walter, Emmanuel e eu estávamos ligados, também, por laços de amizade familiar. Meu pai trabalhara com Oswaldo Cruz, de quem fora discípulo, e Ezequiel Dias fora seu companheiro nos primeiros tempos de Manguinhos. Os três decidimos usar nossos dias livres, que eram muitos, pois com freqüência nos atínhamos a algumas das aulas práticas, deixando de lado as aulas teóricas, para fazermos um primeiro estágio no Instituto de Manguinhos. Falamos com o velho Chagas, que aceitou nossa idéia e nos encaminhou ao laboratório clínico do Hospital de Manguinhos, solicitando a José Guilherme Lacorte que supervisionasse nossa formação laboratorial. Tudo ali era simpático, até mesmo a longa caminhada que muitas vezes tivemos que fazer da Estação do Amorim até o hospital.

Além de José Guilherme Lacorte, o corpo de pesquisadores do hospital era constituído por Eurico Villela, seu diretor e velho companheiro de trabalho de meu pai, que o trouxera de Belo Horizonte para o Rio, e Álvaro Lobo Leite Pereira. Eurico Villela, cuja fisionomia era marcada pelas amplas sobrancelhas que quase mascaravam a profundidade do olhar, era não só um apurado clínico como um experimentado conhecedor das técnicas laboratoriais. De aspecto severo, escondia, no entanto, uma grande suavidade no seu convívio diário. Álvaro Lobo Leite Pereira, sempre jovial e sorridente, era por igual competente e capaz de pôr em função novas técnicas de bioquímica recém-trazidas do exterior. Quando ali chegamos, Álvaro Lobo ocupava-se da determinação de iodo nas regiões ricas em chagásicos, com o fito de estabelecer o possível relacionamento do hipoiodismo com o freqüente bócio observado nos doentes de mal de Chagas. Era afável e respondia com interesse a todas as nossas curiosidades.

José Guilherme Lacorte, muito simpático, embora taciturno, foi realmente o primeiro mestre que tive nas artes científicas. Começou por ensinar-me a reconhecer os vários vidros do laboratório e como devem ser lavados, utilizando-se soluções sulfocrômicas. Em seguida, o manejo das balanças de precisão, pois ainda não haviam as elétricas, como hoje, e a boa medida era feita pelo método da dupla pesagem. Logo após veio a preparação dos esfregaços de sangue e a contagem percentual dos vários tipos de leucócitos. 
A fórmula de Schilling, assim conhecida, era, então, uma novidade. Isto sem falar na hematimetria e na leucocitometria. O hematócrito também não ficou esquecido. Todo esse ensinamento me iniciou no método quantitativo e me serviu, mais tarde, para ministrar, durante dois anos, um curso de princípios de hematologia na cadeira de anatomia patológica. Considero o tipo de iniciação que me foi dado, com pequenos exercícios que partem da preparação adequada do material a ser utilizado e com o aprendizado elementar do método quantitativo, o caminho ideal para dar início ao noviciado prático de um cientista.

No Hospital Oswaldo Cruz, mais tarde Hospital Evandro Chagas, ao mesmo tempo que freqüentava o laboratório, ocupei-me do serviço de ambulatório, no qual tive, inicialmente, a supervisão de Álvaro Lobo. Às segundas, quartas e sextas-feiras, examinávamos, aproximadamente, trinta doentes, na maioria acometidos de verminoses e malária, cujo diagnóstico laboratorial era-me fácil fazer. A vida dessas gentes nos obrigava a levar mais tempo do que o comum na anamnese dos doentes, isto porque já se sentia a importância das condições sociais na evolução de uma doença. Foi nessa ocasião que começou a se formar, em mim, a idéia de que, ao lado do aspecto pastoriano das doenças, há um fator social e somatopsíquico cujo desconhecimento pode tornar a doença crônica. Essa idéia levou-me, muitas vezes, a internar doentes cujo tratamento poderia ter sido ambulatorial, a fim de que pudessem eles receber carinho e, no hospital, alimentação mais adequada do que a que receberiam em casa. Essa experiência me levou, bem mais tarde, quando diretor da Faculdade de Medicina, a fazer com que os alunos, antes de se empenharem nas disciplinas clínicas, fossem obrigados a visitar continuadamente familias de doentes da Ilha do Governador, pois à concepção holística da doença deve-se somar o conhecimento das condições sociais de suas vidas, realizando-se, assim, uma síntese do que deve ser a relação médicopaciente, afastando aquele de uma especialização restritiva.

Durante o tempo em que freqüentei o hospital, Emmanuel Dias começou a trabalhar em tripanossomíase americana, e Walter Oswaldo Cruz em hematologia, particularmente em anemia verminótica. Os dois tornaram-se internacionalmente conhecidos por seus trabalhos. Nos últimos anos em que estive no hospital, juntou-se a nós um jovem estudante de medicina, Haiti Moussatché, que, trabalhando mais tarde com Miguel Ozorio de 
Almeida em um dos laboratórios centrais do instituto, tornou-se, em pouco tempo, um cientista de invulgar prestígio. Dentre os discípulos de meu pai, o mais moço era Gilberto de Freitas, que acompanhou Chagas até o momento de sua morte e se tornou um dos meus grandes amigos.

$\mathrm{O}$ ambiente do hospital era fértil para aqueles que ali conviviam. Particularmente alegre era a hora do almoço, quando nos reuníamos todos, e ao qual compareciam, além de meu pai, alguns dos maiores nomes do instituto. Era uma hora de debates em que fervilhavam idéias muitas vezes contraditórias, mas sempre estimulantes para o surgimento de novos conceitos e a abertura de novas hipóteses de trabalho científico. Para os meus dezessete anos, esses contatos eram extremamente importantes e me permitiam enfrentar o dilema de ser, ao mesmo tempo, filho do diretor e irmão de um jovem que crescia na sua produção científica e no conceito de seus pares. Recordo-me, por exemplo, das discussões sobre o bacteriófago, cuja realidade havia sido posta em dúvida, mas que meu pai defendia com ardor, secundado por um especialista no assunto, José da Costa Cruz, certamente um dos maiores microbiologistas que conheci e freqüentemente convidado para almoçar conosco. Lembrome, ainda, de uma acesa discussão provocada pelo discurso de posse de meu pai, na Faculdade de Medicina, sobre a necessidade da associação da pesquisa ao ensino. Alguns pesquisadores presentes consideravam, ingenuamente, e contrariando os conceitos de Chagas, que o ensino pode ser prejudicial à pesquisa, esquecendo-se de que uma distribuição de tempo bem equilibrada não anula o pesquisador, mas, ao contrário, pode alargar o raio do círculo de seus conhecimentos e de sua capacidade de reflexão.

Foi com pesar que deixei o Hospital Evandro Chagas. É que, trabalhando no Pavilhão Carlos Chagas do Hospital São Francisco de Assis, comecei a interessar-me pela anatomia patológica. $\mathrm{O}$ serviço de necropsia obrigatória desse hospital estava instalado num pequeno prédio ao lado do pavilhão e era ligado, diretamente, à seção de anatomia patológica de Manguinhos.

Com a ida de Eudoro Villela para a França, no usufruto de uma bolsa concedida pela Fundação Oswaldo Cruz - criação infelizmente efềmera de Salles Guerra, que não deve ser confundida com sua atual homônima - um lugar de auxiliar de autópsias surgiu no quadro do Hospital São Francisco de Assis. Pleiteando-o, passei, assim, a trabalhar no lugar de Eudoro Villela, na seção de anatomopatologia, e em Manguinhos. Minha tarefa era árdua, pois 
iniciava o trabalho às sete e meia para que o serviço de abertura de cadáveres estivesse pronto quando chegassem, para o diagnóstico final, os clínicos do hospital e os patologistas do Instituto Oswaldo Cruz: Osvino Pena, Magarinos Torres, Burle de Figueiredo e Azevedo Penna, todos verdadeiros titãs na especialidade. A minha chegada tão cedo ao necrotério era penosa porque, além de jogar basquetebol, à noite, pelo menos três vezes por semana, eu não dispensava passar pelo Café Lamas - velho café querido! - antes de ir para casa, todas as noites.

Os mestres de Manguinhos eram realmente extraordinários e embasbacavam-nos, a todos que assistíamos ao trabalho, pela precisão com que podiam ligar a lesão anatômica ao quadro clínico. $O$ mais fino, nesse sentido, era Osvino Pena, que, ao mostrar a discrepância entre o diagnóstico por eles elaborado e o achado anatômico encontrado na fria mesa de mármore, nunca deixou mal nenhum dos clínicos. Porções das peças anatômicas eram enviadas aos laboratórios de Manguinhos, onde comecei a trabalhar, para que o exame macroscópico fosse confirmado microscopicamente. Foi um período de extraordinário aprendizado, que me fez compreender a importância da relação entre forma e função, ou seja, estrutura e ação, para a boa interpretação dos fenômenos biológicos normais ou patológicos.

Se minha preparação clínica - feita com Eurico Villela na $12^{2}$ enfermaria do Hospital São Francisco e complementada pelo curso de Genival Londres - era apenas satisfatória, a preparação cirúrgica era muito deficiente. Para supri-la, de acordo com meu pai, resolvi passar as férias de verão em Juiz de Fora, onde morava um de meus colegas mais chegados, Maurício Duarte. Naquela mais do que aprazivel cidade fiquei morando na casa do doutor Antônio Augusto Teixeira, na rua Santo Antônio, casado com minha tia Juanita, deliciosa figura feminina, uma das irmãs mais moças de minha avó Mariana. Tia Juanita era um exemplo singular da mãe brasileira, daquelas que Agassiz tão bem descreve no relatório de sua viagem ao Brasil. Religiosa, ia à missa diariamente, e nunca percebi, no seu rosto pleno de bondade, nenhum traço de impaciência ou de irascibilidade.

Antônio Augusto Teixeira era o varão típico da velha Minas Gerais. A voz grossa e o aspecto severo não lhe tiravam os sentimentos de compreensão e amizade com que cercou o sobrinho, no qual encontravam-se, por certo, traços do estabanamento de um jovem carioca. Tempos mais tarde, quando, 
de madrugada, passava de carro pelas cidades de Minas Gerais, ao ver, contrastando com a maioria das casas já de luzes apagadas as bibliotecas de luzes acesas, nas quais provectos varões de idade avançada liam, lembrava-me sempre de sua figura debruçada sobre os livros, em sua biblioteca. $\mathrm{O}$ casal tinha seis filhos. Das três meninas, uma tornou-se freira. O mais velho, Carlos, veio a ser um médico ilustre e um dos fundadores da Escola de Medicina de Juiz de Fora. O mais moço, Antônio, meu coetâneo, tornou-se advogado eminente no foro juiz-forano. José de Castro Teixeira veio para o Instituto Oswaldo Cruz, onde se dedicou, com brilho, à virologia, tendo sido um dos pesquisadores mais diretamente ligados a meu pai.

Para Juiz de Fora levei preciosas descrições e observações de meu pai, que ali passara, intercorrentemente, uma parte da sua adolescência, quando sua avó possuía a Fazenda Bela Vista, no Piau, para depois vir morar na cidade. Com isto quero dizer que já conhecia um pouco das tradições da terra.

Tia Juanita deu-me total liberdade, da qual não abusei. A única coisa que me pediu é que não passeasse na rua onde se instalara o Colégio "Gramberi". Receava que os prosélitos da Igreja Reformada, que haviam instalado magnífico educandário na cidade, me atraíssem para os esportes que ali se realizavam, afastando-me, assim, de Roma. Logo que me arrimei fui procurar Hermenegildo Villaça, o grande médico da cidade, e depois seu filho, João Villaça. Obtive, desse modo, permissão para freqüientar o prontosocorro.

João Villaça era um médico de qualidades excepcionais. Uma de suas facetas, que é a marca dos grandes homens, era a simplicidade no trato, qualquer que fosse o nível social de seu interlocutor. De fina educação, tinha todos os gestos e a elegância de movimentos que devem ser as características de um bom cirurgião. Ao lado de sua impecável técnica, mostrava uma base sólida. Treinado em patologia durante dois anos no Instituto de Manguinhos, Carlos Chagas tudo fizera para vê-lo ingressar em seus quadros. Em vão. Sua inclinação era a prática médico-cirúrgica, e a mística de sua vida, a cidade de Juiz de Fora, onde se instalou logo ao voltar do estágio na Alemanha.

Guardo, dessas temporadas, a lembrança do carinho com que ali fui tratado por Almada Horta, grande amigo de meu pai, e do enternecimento que me davam as tertúlias literárias, nas quais a figura principal era a de Belmiro Braga. 
Voltei, ainda algumas vezes, ao convívio da gente de Juiz de Fora. Gente fina e discreta. Não posso esquecer, por exemplo, umas férias de São João que passei na Fazenda São Felipe, linda propriedade do cunhado de Maurício Duarte, onde se misturavam o cultivo da terra e a criação bovina. Foram quatro dias de incomparáveis festejos e de alegria sem exageros.

No final do quinto ano médico, um episódio veio modificar a minha orientação profissional, direcionada para a anatomia patológica das doenças tropicais. É que fui assistir a uma conferência do professor francês FauréFremiet, do Colégio de França. Falou ele sobre "a cinética do desenvolvimento", apresentando fenômenos biológicos não só analisados matematicamente como, também, interpretados à luz de conhecimentos físicos e químicos. Fiquei deslumbrado, pois tomei conhecimento de que os fenômenos que eu estudava, macro e microscopicamente, na análise morfológica que fazia, podiam ser aprofundados em uma nova dimensão. Esta seria realmente a que poderia explicar o que a aparência morfológica nos ensinava. Concluí que ali estava o caminho que eu queria seguir. Levei algumas semanas refletindo sobre a atitude a ser tomada: passar da patologia médica ao estudo da essência dos fenômenos celulares. Fui ver meu pai e, pela primeira vez, achei-o alquebrado, pois estava sofrendo de um surto de alergia que lhe atacava, regularmente, as mãos. Um pouco narcisicamente, achei que ele ficaria desapontado com o que seria, na verdade, um abandono da ciência médica tropical. Não foi assim que Chagas reagiu ao meu pedido, considerando-o razoável. Pediu, apenas, que eu fosse passar algum tempo no hospital de Lassance para estudar, em contato próximo, os aspectos essenciais de uma parte das moléstias que assolam o nosso país. Organizou-se, assim, uma pequena expedição, na qual me acompanharam Emmanuel Dias, a auxiliar de farmácia Maria dos Impossíveis, e Raul Avelar, que ajudava meu pai em vários misteres e que bem conhecia Lassance e as regiões vizinhas. Para lá partimos, no princípio de janeiro, e nos instalamos no pequeno hospital onde moramos durante os seis a oito meses que ali ficamos. Ajudou-nos, enormemente, em nosso trabalho, o guia original da região, conhecido como "Caburé", cujo apelido nunca soube compreender, pois era ele um homem de seus quarenta anos, de bela prestância, que nada tinha de cafuzo e que se parecia muito com um dos grandes astros do cinema americano de então, Ronald Colman. 
O hospital era um pequeno prédio de um só andar, cinco cômodos, a cozinha e dois banheiros. Um dos cômodos servia de sala de exames, e uma parte de um dos banheiros, de laboratório. Nossas camas eram protegidas por cortinados e, à noite, freqüentemente ouvíamos o bater dos Triatoma infestans, barbeiros invasores de domicílios, contra o filó. Os pés de nossas camas de ferro eram mergulhados em potes de vidro, cheios de soluções tóxicas, impeditivas da subida, para a cama, dos numerosos escorpiões que à noite apareciam. Certa vez, Maria dos Impossíveis, ao tentar pegar um vidro na prateleira de sua farmácia, recolheu o braço com um desses terríveis animais agarrado a um de seus dedos. Foi, certamente, o caso clínico mais dificil com que me defrontei durante a minha estada em Lassance, pois, malgrado o emprego de soro antiescorpiônico produzido pelo Instituto Ezequiel Dias, nada aliviou a dor e o sofrimento de minha auxiliar.

Os dias eram longos. Eu era acordado entre quatro e cinco horas da manhã pelos primeiros doentes que chegavam vindos, muitos deles, de longas distâncias. Gente muito simples, uns mais bem vestidos do que os outros e, apesar das condições sociais muitas vezes precárias, eram eles de grande asseio pessoal; as mulheres vinham sempre acompanhadas pelos maridos. Para minha surpresa, falavam o português sem grandes erros, lentamente, para que cada palavra fosse bem ouvida. Todos tinham um traço de solidariedade com seus compadres e parentes. $O$ diagnóstico não era dificil: verminose, malária e doença de Chagas. As mais das vezes, tinham os chagásicos corações extremamente aumentados - os corações bovinos. Como possuíamos um bom laboratório, um razoável equipamento de raios $\mathrm{X}$ portátil e um eletrocardiógrafo de funcionamento regular, podíamos completar os diagnósticos. Uma vez por semana procedíamos a uma reação de Wasserman com amostras de sangue coletadas durante a mesma. O almoço era seguido de uma pequena sesta, depois da qual partíamos para caçar animais vespertinos. Nos dias em que não caçávamos, ou depois da volta da caçada, dedicávamo-nos aos exames de laboratório e à discussão dos casos vistos. Seguia-se o jantar, servido entre seis e seis e meia, o que nos permitia receber, bem cedo, os sanfoneiros e violonistas que nos encantavam até em torno das dez horas.

A caçada era indispensável para a nossa boa manutenção, já que carne só vinha de Curvelo uma vez por semana. Foi um tempo de cardápios 
extraordinários: codornas, perdizes, jacus, além de rechonchudos leitões presenteados pelos pacientes que atendiamos e que traziam, também muitas vezes, galinhas novas, com as quais o cozinheiro preparava deliciosos pratos ao molho pardo.

Lassance era uma cidade de menos de dez mil habitantes, e as brigas, raríssimas. $\mathrm{O}$ mais importante na minha atividade eram as excursões que fazíamos ao redor de Lassance e que tinham por fim verificar o estado de saúde da população rural e esparsa, seja em pequenas localidades, seja em choças isoladas. Noventa por cento dos habitantes dessas choupanas eram malarientos crônicos ou em estado agudo, e quase todos com ancilostomose. O diagnóstico era, em geral, feito com o auxílio de um microscópio portátil, mas o exame do sangue em gota pendente levou-me semanas para aprender. Uma das experiências invulgares que tive passou-se numa das mais longas excursões. Vendo, ao longe, um grupelho de choupanas, para lá me dirigi mais apressadamente, malgrado as advertências do Caburé, às quais não dei atenção. Ali chegando, percebi a razão de sua preocupação. Tratava-se de uma pequena colônia de hansenianos. Segui com eles a rotina de sempre e encontrei, além da doença maldita, o mesmo quadro mórbido reinante em Lassance: anemia, malária, verminoses etc. A única dificuldade que tive foi ter que saborear o café que, gentilmente, me ofereceram em pequenas latas amassadas pelo uso constante. Consegui fazê-lo sem mostrar a menor dificuldade. O café, aliás, era uma cocção de ervas secas do local, que nada tinha a ver com o sabor do mesmo. A doença os tinha marginalizado. Daí a alegria com que nos receberam.

Muitas vezes as excursões se prolongavam por dois ou três dias, o que nos obrigava a arranchar ao relento, já que nos era impossível aceitar a hospedagem nas casas da região, todas elas provavelmente contaminadas pelo barbeiro. Noites inesquecíveis, em que o calor de uma pequena fogueira protegia-nos do frio que assalta o Planalto Central à noite. A conversa se prolongava até tarde. Mas o melhor nesse entretenimento era o Caburé. Contava-nos estórias de fantasmas, mulas-sem-cabeça, feitiçarias e golpes de mau-olhado. A conviç̧ão que punha no seu relato era total, principalmente nas estórias em que, em encruzilhadas, o gênio das trevas aparecia. Felizmente, para mim, o cansaço da longa caminhada diária me dominava quando eu já estava prestes a acreditar no que ele contava. 
Uma das recordações mais extraordinárias que tenho dessas excursões é aquela em que, chegando depois de uma longa viagem, à tardinha, às margens do rio das Mortes, que passa perto de Lassance, o tropel de nossos cavalos fez com que se levantasse um bando de araras que multicoloriram o céu. Eram cem? Eram mil? Não sei dizê-lo. Georges Bernanos, durante sua estada na vizinhança de Pirapora, assistiu ao mesmo espetáculo. Penso que a ele se referiu em uma de suas cartas a amigos. Dizia ele ser impossivel existir um espetáculo tão lindo e tão surpreendente. De outra feita, chegando à margem de um afluente do rio das Mortes, o cavalo que eu montava retesou-se e, empacado, desobedeceu ao meu comando de ir adiante. A causa de sua reação era uma surucucu que passava na beira do regato. Vi, então, como os animais podem sentir presenças que escapam, totalmente, ao homem.

Ao redor de Lassance, multiplicavam-se propriedades agropecuárias, cujos proprietários viviam, muitas vezes, em Curvelo, talvez mais longe. A vida desses donos de terra não era fácil, e as fazendas, ainda que bem mantidas, não apresentavam as mesmas comodidades das que visitei em outras regiões de Minas Gerais. Lembro-me da simplicidade do vestuário do maior latifundiário e criador de gado da região, que se tornou meu paciente. Suas botinas, por exemplo, eram feitas com a carapaça de tatu pregada numa sola de madeira.

Lassance tinha a rua principal, que acompanhava o leito da estrada de ferro, e pequenas ruas que a ela afluíam. Na avenida Afonso Pena, como era denominada, encontravam-se o mercado principal da cidade, uma farmácia, um açougue, um armarinho, o colégio e, mais ainda, muitas das casas dos "notáveis": o juiz de direito, a professora, a residência citadina de alguns dos fazendeiros, o posto policial e uma pequena capela. Duas ruas se destacavam pelo grande movimento: a do "Tiro" e a da "Faca", cujos nomes verdadeiros nunca cheguei a conhecer. Nelas, a grande maioria das casas era constituída por albergarias, ou então bordéis. Nesses locais permaneciam, por alguns dias, os boiadeiros que traziam manadas do interior da Bahia para o abate, em Curvelo. A parada em Lassance servia ao descanso dos peões e, ainda, para o fortalecimento do gado, pois as invernadas que circundavam a cidade eram de boa qualidade, permitindo, em pouco tempo, a engorda da boiada cansada. Os bordéis prestavam homenagem aos visitantes da cidade, que compareciam como convidados de honra aos bailes de sábado. 
Tinham esses convidados o privilégio de conservar as suas armas, não sendo obrigados a depositá-las em um baú posto na entrada das casas, o que acontecia com todos os outros freqüentadores. Os homenageados não podiam dançar e a eles cabia a conta da cerveja consumida durante a noitada que terminava, impreterivelmente, à meia-noite. A esses bailes vinham os homens da avenida Afonso Pena, nunca acompanhados de suas mulheres, às quais era proibido o convívio com as rameiras. O comércio na cidade era baseado, principalmente, no sistema de escambo: leite por verduras, ovos por carne, e outros, já que o dinheiro era muito escasso. Uma nota, mesmo de valor pequeno, era uma posse valiosa, e as moedas, brincadeira de colecionador. Um exemplo que posso dar da importância relativa do dinheiro passou-se durante uma caçada que fiz. Íamos em busca de uma onça-preta que estava atacando bezerros pelas fazendas da vizinhança. Numa noite de vigília, quando esperávamos o quase amanhecer, iluminados por uma pequena fogueira na serra do Cabral, me contou Sinhô José, o "onceiro" que nos acompanhava, que havia ele trocado de mulher, mas fora obrigado a recompensar seu comparsa na barganha com dez mil-réis, já que sua nova companheira era de cor branca, e a outra, índia. Em verdade, uma grande parte da sociedade lassanciana era machista, do que dá prova o episódio contado, o que era comum nas cidades brasileiras, mesmo nas de maior porte, como nos é referido por F. Biard no seu livro Deux années au Brésil (1862).

Em Lassance, não foi o contato com a natureza primitiva, nem com a força de seus elementos - as trovoadas, a chuva espessa - tampouco a beleza das noites crivadas de um sem-número de estrelas, entre as quais fulgia, de quando em vez, uma estrela cadente, o que mais me encantou. Foi a gentileza dos homens e das mulheres que lá encontrei. Simpáticos, evocadores das palavras de Deus, tinham na sua simplicidade alguma coisa de evangélico. Se pareciam gente de pouco riso, tinham como próprio cimento da comunidade uma solidariedade que, as mais das vezes, vencia as dificuldades intergrupais. A falta de ociosidade era uma das características daquela gente afeita a toda espécie de obstáculos materiais. De madrugada saíam para os seus afazeres rurais e só depois do sol se pôr é que as pequenas baiúcas se enchiam para o prazer de uma pinga, sempre excelente, de fabricação local ou oriunda das cidades do vale do São Francisco e raramente absorvida com exagero. 
A vida terminava cedo, e às oito horas as luzes eram apagadas. Aqui e acolá havia uma rixa, muitas vezes seguida de um trocar de tiros de velhas garruchas - e não de revólveres, como se vê nos filmes de bangue-bangue - a indicar que os tempos modernos ainda não se haviam integrado aos hábitos da cidade. No hospital, ouvíamos os tiros disparados no centro ou em seus arredores. Como caminha com facilidade o som nas terras despovoadas e de mato rasteiro! Se houve feridos em algumas dessas rixas e por certo que sim -, nunca fui procurado por nenhum. É que nós, do hospital, éramos considerados como autoridade e, portanto, seríamos obrigados a tomar providências junto ao posto policial, sempre alheio a essas disputas. $\mathrm{Na}$ verdade, não estávamos preparados para atos cirúrgicos de maior extensão.

Foi, sem dúvida, em Lassance que aprendi a conhecer as gentes e a apreender melhor o que é a vida. O contato com os pacientes, a simplicidade da linguagem e a sinceridade dos sentimentos do povo que ali conheci foram da maior valia para a formação da minha própria personalidade. Agradavam-me, sobretudo, nesse convívio simples, as numerosas referências que os menos moços faziam a meu pai, que ali vivera por dois anos, pelo menos duas décadas antes. Falavam como se ele ali estivera na véspera. Cada um tinha um caso de um parente que meu pai tratara e, do episódio, guardava a recordação da dedicação, do zelo e da preocupação de Chagas com os seus pacientes. Outros, que com ele haviam caçado, elogiavam sua boa pontaria, sua infatigabilidade e a generosidade com que distribuía o butim que, com maestria, havia obtido. Nunca cheguei a caçar com meu pai, mas sei quanto se sentia remoçado e revigorado nas longas horas que passava espreitando o alçar vôo de uma perdiz ou de uma codorna, açodadas pela chegada intempestiva dos cães caçadores. $O$ convívio com a população de Lassance trazia-me à lembrança os colonos e os tropeiros com quem tantas vezes me entretive na Fazenda da Tartária.

O calor humano dos habitantes de Lassance tornou amena a minha permanência de quase um ano, interrompida por duas vindas ao Rio: para prestar exames nos cursos equiparados, ministrados por livres-docentes dentre outros, Genival Londres, Maurity Santos, Artidonio Pamplona -, e também para uma supervisão, por parte de meu pai e de Evandro, do que eu lá havia apreendido. Sem dúvida, foi uma experiência de clínica que 
ficou em minha memória para sempre e deu-me mais confiança no atendimento que me cabia fazer no ambulatório do Hospital Evandro Chagas. Parti de Lassance certo de que estava mais preparado para a vida e convencido de que deveria realizar o meu desejo de ingressar, o mais rápido possível, no estudo das ciências básicas que servem à medicina. 


\section{III}

\section{Aprendiz de ciência}

hegado ao Rio, retomei uma parte da rotina que deixara. Substituí o basquetebol pelo "frontão" - pelota basca - no campo da rua Visconde de Rio Branco, onde conheci personalidades diferentes. Eram os pelotários profissionais. Tinham uma concepção de vida muito diversa da grande maioria das pessoas com quem até então eu convivera. Uns eram useiros e vezeiros em trapacear, outros corriam atrás da pelota com toda a seriedade e eram insuscetíveis às trapalhices vantajosas que thes eram oferecidas pelos aficionados do jogo. Dois deles tornaram-se meus amigos: Ramuntcho e Taccolo, ambos bascos. Várias vezes - seja com Emmanuel Dias, seja no automóvel que meu irmão me emprestava - após uma passada rápida no mercado da Praça Quinze, onde comprávamos peixe, íamos para a Barra da Tijuca. Lá, qualquer um dos dois preparava o peixe na grelha e temperava à moda das terras de Espanha. Um dia, procuraram-me no hospital. Iam embarcar para Xangai, paraíso dos pelotários, com um substancial contrato no bolso. Graciosamente, convidaram-me a ir com eles.

A grande atração profissional no Rio era o Pavilhão de Doenças Tropicais. Cheio de vida, pairava entre os que o freqüentavam um entendimento que poucos grupamentos médico-sociais terão tido. De lá, de acordo com a combinação feita com meu pai, seguia para Manguinhos a fim de iniciar a minha formação científica em matérias básicas. Muitas vezes, quando não havia autópsia, eu gazeteava a enfermaria para ver se alcançava, na Leopoldina, o chamado "trem das professoras", em que "iam todas sedutoras para a escola 
trabalhar", como cantam Benedito Lacerda e Cristóvão de Alencar numa canção divulgada pela voz de Sílvio Caldas.

Levava comigo para o laboratório o longo aprendizado adquirido nas mesas de autópsias e a minha admiração pelos que ali me haviam ensinado: Osvino Pena, provavelmente o mais brilhante dos patologistas brasileiros, Magarinos Torres, um operário de seu trabalho científico, Burle de Figueiredo, sempre preciso, ainda que pouco detalhista, e Azevedo Penna, o mais moço e com o qual, por esta mesma razão, tinha mais intimidade e mais facilidade em solicitar-lhe informações, mesmo que banais.

Deixando a anatomia patológica, sem me esquecer da necessidade de ligar função e forma, fui estagiar em Manguinhos no laboratório de José da Costa Cruz, cientista com vestigios de sua formação secundária ecoando na simpática prosódia portuguesa adquirida no seu curso de humanidades, feito em Lisboa. Paraense e lisboeta, tornara-se um carioca típico. Costa Cruz era personalidade do mais alto valor, do que dá testemunho a confidência feita, muitos anos mais tarde, pelo belga Jules Bordet, nobelista de fama pelos seus trabalhos sobre imunologia, que me disse ter sido ele o melhor dos alunos que haviam passado pelos seus laboratórios. Ante a minha perplexidade, continuou: "Neste número estão incluídos todos os estrangeiros, e, ainda, os meus compatriotas." Costa Cruz trabalhava numa metade do pequeno edificio do relógio, que hoje abriga a Casa de Oswaldo Cruz, cuja outra metade fora destinada ao Serviço da Peste, onde trabalhava Henrique de Aragão. Seu laboratório, destacado centro da microbiologia no Brasil, era relativamente pequeno. A presença de seu chefe, de um ou mais estagiários, e a minha, tornavam-no uma colméia pequena para as suas abelhas, todas dominadas pelo carisma de Costa Cruz. Muito cordial, procurava, nas horas vagas, entreter-se comigo discutindo problemas variados que iam da filosofia, em que eu era muito pouco valoroso, até religião, passando pelos temas que começavam a preocupar o mundo intelectual e a sociedade: o freudismo, difundido no Brasil pela obra de Porto-Carrero e pelos artigos admiráveis de Medeiros de Albuquerque, e o marxismo, ainda enquistado em certos núcleos que formavam as células iniciais do futuro partido. Provavelmente, pela minha formação "centrista", em que os valores clássicos da sociedade brasileira eram prestigiados, nunca me aproximei do comunismo, malgrado a profunda admiração que partilhava com os jovens da minha geração, por Luiz Carlos 
Prestes, que, com a sua "coluna da liberdade", atravessou o Brasil de cabo a rabo, lutando pelos oprimidos e enfrentando o "oficialismo". Também estabeleceu-se, entre mim e o freudismo, uma certa hesitação, que persistiu por muito tempo. É que, na ocasião, já havia eu obtido boa informação dos mecanismos que regulam a atividade do sistema nervoso central e não compreendia como as hipóteses freudianas podem se coadunar com os progressos da biologia moderna. Pouco a pouco, começam a se estabelecer laços cientificamente significativos entre o corpo e a mente, o que já era intenção de Sigmund Freud, como podemos ver seja no Projeto para uma psicologia cientifica (1895), seja em O ego e o id (1923), quando ele fala "do misterioso salto do corpo à mente".

Costa Cruz também gostava de discutir literatura e, naturalmente, o seu forte eram os mestres portugueses. Nas discussões, permitia-me opor a minha ignorância ao seu conhecimento, sem se irritar ou me deixar em situações ridículas. Nossas controvérsias continuavam, freqüentemente, no caférestaurante Heim, na rua da Assembléia. No fim de alguns meses, ele me havia ensinado as técnicas habituais da microbiologia, a formação de colônias, a separação de gêneros pelo aspecto de suas colônias, e as várias técnicas de fermentação que permitem identificar espécies. Tínhamos um relacionamento extremamente agradável, do que dá prova o fato de que, alguns anos depois, quando se desenvolviam as técnicas modernas da biologia do pós-guerra, no Instituto de Biofisica, pediu-me que o acolhesse na Praia Vermelha, o que fiz com o maior prazer. Ocupava-se, então, da cristalização de proteínas biológicas, começando pelo bacteriófago. Infelizmente, a sua colaboração durou pouco tempo porque, rapidamente, uma apendicite aguda o levou.

O meu afastamento da microbiologia foi orientado pelo próprio Costa Cruz, que um dia me chamou ao seu gabinete e me disse que, naquele momento, a microbiologia era uma ciência quase esgotada e que só poderia sobreviver quando a ela fossem aplicados os métodos que a biologia começava a absorver da fisica e da química. Falou-me da necessidade de encontrar sistemas que permitissem uma observação mais profunda da morfologia das bactérias. Esse sentimento, dizia ele, nascia da frustração que tinha em não poder identificar o bacteriófago, embora sabendo da sua existência. Costa Cruz foi um dos primeiros pesquisadores, fora do círculo limitado do Instituto Pasteur, que admitiram a existência do vírus descrito por d'Hérelle, cujas características 
e ação antibactericida eram dele bem conhecidas. Esses estudos levaram-no a pesquisar, com cuidado, as propriedades gerais dos vírus através do bacteriófago. $O$ seu tratamento do assunto era atraente. Uma vez levei Enrico Fermi ao laboratónio de bacteriófagos, visita durante a qual - estamos em 1935 - Costa Cruz fez a Fermi uma exposição sobre as propriedades do vírus e, particularmente, do bacteriófago. Essa exposição modificou completamente o programa de visita de Fermi ao Instituto Oswaldo Cruz, em vista do tempo durante o qual os dois cientistas conversaram. Fermi tinha um compromisso para realizar uma conferência na Academia Brasileira de Letras e, era óbvio, iríamos chegar atrasados àquela reunião, muito mais mundana do que científica. Enrico Fermi olhou as horas marcadas no topo do edifício do qual saíamos e disse-me, um pouco preocupado: "Você há de me desculpar a perturbação do horário prefixado. É que os vírus são, por certo, alguns dos sistemas de maior interesse que se encontram na natureza. Se eu tivesse que começar de novo, certamente iria me dedicar ao seu estudo." Tais palavras indicam a extraordinária visão de um cientista que já havia, na ocasião, produzido a desaceleração dos nêutrons, a contribuição decisiva que, nas mãos de outros, permitiu a eclosão do engenho nuclear.

Repensando as palavras de Costa Cruz, resolvi deixar o laboratório de microbiologia e procurei estagiar no laboratório de Miguel Ozorio de Almeida, cuja excelência experimental só era superada pelos seus conhecimentos de matemática, fisica e química. Dedicava-se ele ao estudo do sistema nervoso central, à relação entre superfície tegumentária do tônus muscular e à crioepilepsia.

Ao contrário de Costa Cruz, Miguel Ozorio era esguio, alto, marcado o seu rosto muito menos pela barba, que sempre usou, do que pela vivacidade do seu límpido olhar azul-claro. Convidado por Chagas, viera para Manguinhos, deixando, assim, o laboratório particular que dividira, inicialmente, na rua Almirante Tamandaré e, depois, na rua Machado de Assis, com seu irmão Álvaro Ozorio. Esse laboratório, que foi criado e subsidiado por Cândido Gaffré, sucede, na lista de laboratórios de fisiologia, àquele que, meio século antes, Louis Couty, preparador no Colégio de França, e João Batista Lacerda, haviam fundado no Museu Nacional.

O laboratório da rua Machado de Assis, que eu tive a oportunidade de freqüientar já no seu ocaso, era um centro de vivência científica e intelectual. 
Entre outros freqüentadores, Amoroso Costa, Fernando Laboriau, Paulo Galvão, Antônio Silva Mello, Otávio Couto e Silva e Branca Fialho participavam das tertúlias nas quais os mais variados problemas científicos, sociais e muitas vezes históricos eram discutidos. Ali surgiu o trabalho de Álvaro Ozorio $A$ determinaşão do metabolismo básico no homem tropical, importante sob dois aspectos: o primeiro diz respeito à íntima relação de um ser humano com o seu ambiente, relação essa na qual procurou-se determinar as leis fisicas que regulam a transmissão do calor de um corpo qualquer ao meio que o circunda. $O$ segundo é o da criação de um conceito fundamental para o nosso país: o emprego de modelos nacionais estudados pelas técnicas as mais avançadas, o que, de um modo geral, significam técnicas intemacionais. Esse conceito define e determina o que se deve chamar "a ciência nacional". Isto não significa nenhum tipo de xenofobismo ou de estreito nacionalismo, mas é o melhor caminho para o desenvolvimento natural e social de nosso país.

Foi observando o cuidado com que Miguel preparava o seu arranjo experimental e a atenção com que acompanhava o desenvolver de uma experiência que cheguei à conclusão de que podemos distinguir, na investigação científica, duas fases de igual importância. A primeira é o arranjo experimental que, na sua simplicidade - o que torna mais fácil a execução da experiência -, determina o seu aspecto estético. A segunda é o cuidado a dar aos mínimos detalhes, o que garante a qualidade da mesma e a sua reprodutibilidade. É a reunião dessas duas características que torna perene qualquer experimentação.

Miguel Ozorio chegava ao laboratório no seu automóvel e, no seu invulgar desejo de precisão, dava-nos conta do tempo que havia levado de sua casa, na estrada do Açude, Alto da Boa Vista, até Manguinhos. Procurava todos os dias melhorar a sua performance, o que também fazia nas suas experiências quotidianas. Nestas, a perfeição, a elegância e a economia dos gestos provocavam sempre a minha admiração. Lembrando-me delas com freqüiência, penso num pequeno ensaio de Paul Valéry que descreve, na beirada do Sena, a perfeição com que um decaído encadernador de livros preparava os que lhe haviam sido entregues. Nem um gesto a mais. Nem um ornamento que desse assimetria à cobertura do volume, tampouco a menor sombra de desordem na reposição do material usado. Mais tarde, vim a encontrar no ateliê de Cândido Portinari e, depois, no de Glauco Rodrigues, a mesma 
limpeza e a mesma ordem que Valéry presenciara na pequena oficina das bordas do Sena. $O$ ensaio de Valéry fez-me estabelecer uma distinção na realização experimental. De um lado, a precisão; do outro, a elegância. Foi ainda naquele laboratório que tive a oportunidade de conhecer, conviver e tornar-me amigo de Mário Viana Dias e Haiti Moussatché.

Alguns meses depois, um pequeno episódio arrefeceu o meu entusiasmo por Miguel Ozorio, arrefecimento que durou muito pouco tempo. Miguel dera-me para ler e comentar um artigo seu sobre a teoria elétrica da excitação dos nervos. $\mathrm{O}$ artigo era muito mais matemático do que fisico e eu o deveria ter recusado, dada a minha incompetência. Aceitei, no entanto. Li-o com o maior cuidado e, no fim de algum tempo, levei-o de volta e tive a coragem de indicar o que pensei serem erros. Miguel nada disse e agradeceu-me o interesse. Alguns dias depois, íamos para a cidade - Miguel Ozorio, Carneiro Felippe e eu, no Ford que Miguel apelidara de "Nêutron" - , quando, sentado no fundo, ouvi Miguel quase sussurrar a Felippe: "Você sabe, eu sou um indivíduo muito liberal. Entreguei um artigo meu ao Carlinhos para que ele fizesse os comentários e ele encontrou vários erros, que na verdade não o eram. Eu não me incomodei nada com isto e não mudei meu relacionamento com ele." Esse episódio me fez procurar um outro orientador, mas, ao mesmo tempo, foi para mim uma lição modelar: a de discutir com os meus companheiros mais moços os erros que eu cometera. Não me era fácil deixar a companhia de Miguel Ozorio, que muito me atraía, e não sabia como resolver o impasse. A solução veio do próprio Miguel Ozorio, que, disposto a fazer uma longa viagem pela Europa, aconselhou-me a trabalhar, na sua ausência, com Carneiro Felippe.

José Carneiro Felippe era, por assim dizer, um recém-chegado a Manguinhos. É que meu pai desejava estender a ação do instituto à fisiologia e à fisico-química. Para a fisiologia, escolheu Miguel Ozorio de Almeida. Para a fisico-química, a escolha recaiu sobre Carneiro Felippe, uma das pessoas de maior conhecimento científico e cultural que conheci. Surgiu a escolha de Felippe de uma viagem de Chagas a Belo Horizonte, onde o encontrou à frente do laboratório de análises fisicas e químicas que organizara naquele estado. Depois de várias entrevistas, Chagas convenceu o ilustre governador de Minas Gerais, Raul Soares, a abrir mão do seu auxiliar, pois o laboratório já estava organizado e em pleno funcionamento rotineiro. Carneiro Felippe, 
que tinha grande interesse por questões biológicas, aceitou o convite. Fora ele aluno laureado da Escola de Minas de Ouro Preto e, após a graduação, voltara para sua cidade natal, São João del Rei, ocupando-se da extração e venda de minérios. Ao mesmo tempo, seu interesse pelo progresso científico e sua formação básica na escola fundada por Gorceix permitiam-lhe acompanhar os grandes progressos da fisica e da mineralogia, realizados no primeiro quartel do século XX. Sua aparência frágil era acompanhada de um constante pigarro, conseqüência, certamente, de ser fumante inveterado e, muitas vezes, de cigarros de marca comercial. Freqüentemente, no entanto, preparava-os com suas próprias mãos, usando fumo forte enrolado em folha de palha, numa constância igual apenas àquela com que ingeria café, fortíssimo, permanentemente requentado em bule disposto sobre um bico de Bunsen. Carneiro Felippe era de uma simplicidade só comparável à sua capacidade intelectual. Foi ele quem completou a minha preparação científica: ensinoume a manejar microscópios complexos, instrumentos de determinação do indice de refração, as técnicas habituais de dosagem química, inclusive a determinação elementar dos componentes de uma substância, e, mais do que tudo, iniciou-me no método quantitativo e na análise estatística dos resultados experimentais obtidos. Tentou, ainda, introduzir-me no que, para mim, era um misterioso mundo: o da epistemologia. Muitas vezes passei os fins de semana em Manguinhos na sua companhia. Dormíamos nos quartos adrede construídos por Oswaldo Cruz, no terraço do edificio central, para que os pesquisadores da instituição nela pudessem pernoitar. Esgotado pela fadiga do dia, embalavam-me os ruídos do silêncio que conhecera nas noites do sertão e que também povoam os espaços vazios dos grandes edificios. Seriam, provavelmente, a contração ou a dilatação de paredes e de portas, mas tinham um tom misterioso, que me servia de acalanto. Aos domingos, à tarde, quando a estrela-d'alva apenas despontava, tomávamos a pé o caminho da estação. Nunca deixei de me assombrar com a maneira precisa com que Carneiro Felippe identificava uma planta ou um arbusto durante a caminhada. Apontando-me o céu, informava-me das características das várias estrelas, cujo brilho já vencia o lusco-fusco do entardecer, da sua posição dentro de uma constelação e, muitas vezes, de sua proximidade da Terra. De vez em quando parava, perguntando-me se eu conhecia tal ou qual poeta clássico. Antes que pudesse responder, repetia-me, na sua voz clara e na sua dicção 
mineira, um soneto ou uma ode da poética portuguesa ou brasileira. Pareciame estar na presença de um grande vulto da Renascença. Entre nós estabeleceuse uma relação de mestre e aluno como as que existiam outrora. Depois de passar com ele o dia em Manguinhos, bem tarde da noite, às vezes depois do cinema ou do basquetebol, ia eu à casa de Carneiro Felippe, na rua Visconde de Caravelas, onde nos entretínhamos discutindo ciência. Subia diretamente para a sua biblioteca e ali começavam os seus ensinamentos, que iam até o sol raiar. Foi assim que, utilizando um método preponderantemente histórico, ensinou-me o mestre a teoria dos quanta, a história da radioatividade e os princípios básicos que caracterizam as radiações corpusculares ou ondulatórias, os princípios da física atômica, os rudimentos da teoria da relatividade. Um dia perguntou-me como eu definiria a ciência. Disse-lhe que, para mim, a ciência era a busca do conhecimento por métodos particulares que caracterizam cada disciplina científica. Ponderou-me, nessa ocasião, que o homem primitivo também seria um cientista, ao que respondi positivamente, mas que a ciência só se desenvolveu quando instrumentos materiais ou convencionais, como no caso da psicanálise, foram se aperfeiçoando. Acordei com Felippe o conceito de que a ciência é uma parte da filosofia, aquela que cuida do meio em que vive o homem, das relações entre os seres vivos e da sua evolução. Por ser, na verdade, uma emanação através do consciente de intuições do inconsciente $e$ da alma do ser humano, a ciência, por isso mesmo, se conjuga, no quadro das realizações humanas, com a arte e todos os momentos de criatividade.

A convivência com Carneiro Felippe ensinou-me, também, que o cientista deve ser um homem de um só objetivo, o conhecimento, mas que não pode, de modo algum, deixar que esta busca, bem como a linha que a ele leva, se despregue de fatos, ocorrências e informações, os quais muitas vezes se situam longe da linha-mestra. $O$ pesquisador que assim proceder não passará de um simples pantomimeiro e nada dará de contribuição verdadeira a essa extraordinária realização do espírito humano que é a ciência. Desse modo, Carneiro Felippe, ao me dar as bases de um conhecimento técnico que me permitiram até mesmo a realização extremamente complexa de um aparelho de medição de $\mathrm{pH}$, medição essa hoje tão simplificada que pode ser manejada pelo menor dos principiantes, mostrou-me a importância do encontro da ciência com as outras atividades do espírito humano. Não é demasiado afirmar que, ao lado de meu pai, foi Carneiro Felippe quem me indicou as veredas da pesquisa científica. 
Minha vida era preenchida por intensa agitação, pois, além das atividades de formação médica, no Hospital São Francisco de Assis, e de iniciação cientifica, em Manguinhos, o basquete e a pelota basca, entre outros esportes, serviam ao desenvolvimento do meu corpo. Além do mais, havia a parte cultural. É dessa época a leitura de dois livros muito diversos, mas de fundamental importância na minha formação: Jean Christophe, de Romain Rolland, que me mostrou o que mais tarde Bernanos fortaleceu, isto é, a imperiosa necessidade de não aceitar tabus e prepotência. $O$ outro, contraface dessa medalha, Em busca do tempo perdido, de Proust, principalmente na descrição do que se passava nos salões dos "Guermantes", ensinou-me a procurar sempre colocar as pessoas nas dimensões do seu próprio mundo, e quebrou discriminações, ensinando-me o respeito a comportamentos muitas vezes rechaçados. Estava longe da Mme. de Ségur e de Jules Verne. Os novos autores levaram-me ao caminho de Mauriac, Green, Rosamund Léman, Maurice Baring, Thomas Mann, Hermann Hesse, e aos escritores americanos que formam o ciclo de ouro do pós-guerra de 1914-1918.

$\mathrm{O}$ mundo da música invadiu-me sob vários aspectos. Pequeno, ouvira minha avó Maria Lobo tocar no violão os clássicos da música erudita. Era uma brava violonista. Minha desabrida paixão pelos grandes vultos da Revolução Francesa forçava-me, cada vez que ela se dispunha a tocar violão, a pedir que encerrasse seu recital enchendo o salão com os vibrantes acordes da Marselhesa. E mais: completava meu prazer ouvir meu irmão que, além de vários instrumentos, também tocava violão $e$, com voz afinada, cantava toadas sertanejas. As minhas alegrias musicais eram exaltadas, mais ainda, pela minha participação, na qualidade de comparsa, nas óperas levadas à cena no Teatro Municipal. As temporadas eram fabulosas. Os grandes cantores operísticos de passagem pelo Rio demoravam-se, ora na ida, ora na vinda do Teatro Colón, de Buenos Aires. Entre as óperas inesquecíveis cito A Traviata, de Verdi, com Claudia Muzio e Miguel Fleta, de cujas árias mais importantes lembro-me até hoje e tento cantarolar. Quando se montou um excepcional espetáculo em comemoração à posse de Washington Luís como presidente da República, um dos trechos escolhidos foi aquele em que a Traviata recebe a sociedade parisiense. Nele se celebra a alegria com a famosa estrofe que começa com o verso "libiame nei aliete calice che la belleza infiora". Enverguei, para o meu encanto, um uniforme de mordomo para 
servir champanhe aos convidados da Dama das Camélias. Pude, assim, estar perto dos grandes artistas que transformaram aquele evento numa noite extraordinária e única para mim. É que eu já me havia esquecido do medo com que, aos sete anos de idade, assistira, levado por meu avô Fernando Lobo, ao Mefistófeles, e as dificuldades que encontrara em Wagner se haviam esmaecido.

Nas várias oportunidades que tive de ir ao Municipal, assisti, ainda, a Carmen, de Bizet, com Gabriella Besanzoni Lage, cuja voz, de tão forte, fazia estremecer os cristais que adornavam o palco, e a L'elisir d'amore, cantado por Tito Schipa, além das óperas em que eu entrava de penetra ou, então, misturava-me ao coro. Certa vez, por estar minha mãe doente, fui com meu pai a uma temporada wagneriana. Ouvir todo o $O$ anel dos Nibelungos, de Wagner, foi dificil, mas certamente constituiu uma das sementes da minha posição anti-hitleriana, a qual me levou, logo depois do golpe de Munique, a uma rixa num pequeno bar da rua da Lapa, $O$ Túnel, conflito iniciado pelo próprio dono do estabelecimento, um alemão de vastas proporções, ofendido por ter eu cantado, com voz forte, uma canção antihitleriana, na qual dizia-se que em Berlim estavam os loucos: "Nach Berlin wo die verükten sind".

Ao lado das óperas, era assíduo aos concertos. No Municipal, assisti aos maiores musicistas da época, sendo Brailowsky o meu favorito. Nunca me esqueci da primeira vez em que o ouvi tocar a Appassionata.

$\mathrm{O}$ teatro de comédias era menos procurado por mim. Nele dominava a presença de Leopoldo Fróes, mais tarde seguido por Procópio Ferreira. Fróes, com a sua prosódia portuguesa, era um artista admirável: simples nos gestos, forte na expressão e muito insinuativo na entonação. Em companhia de colegas, ia ao que hoje chamam de "musicais", no Teatro Recreio: um misto de comédia musical e muito de chanchada. A recordação mais viva que guardo daqueles momentos vem de ter assistido à estréia de Sílvio Caldas, ali cantando a bela canção Formosa.

Os grandes sucessos anuais eram a vinda de Chabi Pinheiro - que lotava o enorme Teatro Lírico pela presença maciça da colônia portuguesa, ainda extremamente numerosa e rica na cidade - ou de uma trupe francesa, às vezes de teatro leve, outras de comédia dramática. Esta última teve, durante a Segunda Guerra, uma revivescência com os espetáculos de Louis Jouvet e 
Madeleine Ozeray e, nos anos cinqüenta, pelas várias turnês da companhia de Jean-Louis Barrault e Madeleine Renauld. Estes tornaram conhecida do público brasileiro a poesia de Paul Claudel, que aqui viveu como ministro plenipotenciário da França nos últimos anos da guerra de 1914-1918.

Assinalo, ainda, pela influência que exerceram em mim, os sucessivos espetáculos de Berta Singerman. Declamadora de excepcional qualidade, também lotava o Teatro Lírico. Levou-me a apreciar a arte declamatória genuína e a me entusiasmar por certos poetas de língua espanhola, alguns latino-americanos, como Ruben Dario e Amado Nervo, cujos versos sabia de cor. Um dos poemas de Amado Nervo, "Cobardia", é uma bela lição de desprendimento, assim como "Los caballos de los conquistadores", de Dario, o maior épico da conquista da América Latina pelos aventureiros espanhóis. A admiração que tenho por esse poema não perturbou a posição anticolonizadora que tem sido a minha. Continua ela a mesma, pautada, entretanto, por certos conceitos fundamentais, entre os quais o de que uma nação que não sabe impedir um sistema de colonização, qualquer que ele seja, não merece ser uma nação.

Minhas atividades culturais não me afastaram, por um momento sequer, do meu desejo de apreender o que pudesse no meu estágio de formação, em Manguinhos. No laboratório de Carneiro Felippe encontrava-me constantemente com outros cientistas do instituto que iam procurá-lo para discutir hipóteses e resultados. Sem participar diretamente desses colóquios, a eles assistia como ouvinte. Muitas vezes Carneiro Felippe vinha rediscutir comigo os assuntos debatidos, certamente com o objetivo de dar oportunidade ao desenvolvimento do meu pensamento. Entre os interlocutores mais freqüentes de Carneiro Felippe encontravam-se Alcides Godoy e Astrogildo Machado.

Godoy tinha trabalhado em vários assuntos, mas naquele momento interessava-se, principalmente, pelo desenvolvimento da microscopia óptica, que, admitia ele, podia se desenvolver com novas tecnologias. Godoy tinha tido uma formação invejável porque, logo no princípio de sua carreira, fora enviado por Oswaldo Cruz para um longo estágio no Instituto de FísicoQuímica criado por Wilhelm Ostwald, em Leipzig. Com sólido apoio do governo imperial alemão, Ostwald, em conjunto com, entre outros, os eminentes cientistas Jacobus van't Hoff e Svante Arrherius, dera origem a algumas das principais raízes da fisico-química moderna. Alcides Godoy era 
extremamente brilhante, e a tal ponto que, muitas vezes, era dificil acompanhá-lo. Seu pensamento corria mais depressa do que o lápis ou o giz com que desenhava um esquema no papel ou, em seus cursos, no quadro-negro. Tinha uma perfeita noção da separação entre a ciência básica e a aplicada, mas considerava que o interfluxo entre elas deveria ser constante. Astrogildo Machado, ao contrário do ser ebuliente que era Godoy, caracterizava-se como um indivíduo calmo e extremamente cuidadoso na evolução do seu pensamento. Pesquisador de talento, era muito ligado à aplicação dos conhecimentos adquiridos, mas não em sua busca para a utilização na prática. Vê-lo pesar ou preparar uma solução era um espetáculo, tal a precisão com que o fazia. Godoy e Machado foram os autores da vacina contra o carbúnculo sintomático, e Godoy, aquele que, precedentemente, havia criado a vacina contra a peste da manqueira.

Nesse período, resolvi me inscrever no curso de aplicação do Instituto de Manguinhos. Curso excelente, ainda que moroso. Era lecionado pelas principais figuras do Instituto Oswaldo Cruz. E, se havia disciplinas mais concentradas, outras, pela sua própria natureza, eram lecionadas em tempo mais extenso. É o caso da bacteriologia, na qual tive como professor João Carlos Nogueira Penido. A preparação era muito segura porque semeávamos os vários microorganismos em um dia, esperávamos o seu crescimento vinte e quatro horas depois e aí começavam as reações químicas, principalmente de fermentação, necessárias à sua identificação. Penido tinha acompanhado algumas das missões de Manguinhos ao interior do país, o que o tornava um excelente companheiro para o aperitivo, que tantos de nós tomávamos ao voltarmos do instituto. Encantavanos com a série de estórias que tinha acumulado nessas excursões.

De todas as disciplinas, a microscopia foi a mais dificil para mim, ministrada por Godoy com grande precisão e, às vezes, como eu pensava, com teoria. Foi durante o curso que conheci um dos grupos mais fortes do instituto: o da zoologia médica, em que ponteavam Cesar Pinto, excelente didata, e o entomólogo Ângelo Moreira da Costa Lima, figura singular das ciências brasileiras. A seriedade de sua atitude professoral era trocada, no laboratório, por uma deliciosa bonomia em que se misturavam informações preciosas sobre a biologia dos insetos. Extremamente simpático, nunca se estabeleceu, entre nós, qualquer obstáculo que pudesse ter nascido da diferença de idades ou da minha posição, muitas vezes dificil, de filho do diretor. 
Outro professor excepcional pelo seu conhecimento era Aristides Marques da Cunha, cujo prognatismo dava-lhe um ar de grande simpatia. Lecionava protozoologia de uma maneira extraordinariamente interessante. Se, na primeira aula, a bitonalidade de sua voz provocou o riso entre alguns de nós, deixou, mais tarde, de ser percebida, tal a qualidade de sua preleção, a minúcia de suas demonstrações microscópicas e o interesse suscitado pelas questões que nos propunha. Durante anos foi, para mim, um prazer ir ao seu laboratório para explorar-lhe o conhecimento e a verve.

Seduziu-me, desde logo, a personalidade de Lauro Travassos. Lauro tinha uma figura impressionante: alto e corpulento, voz clara e forte, e entradas profundas separavam o cabelo partido ao meio. Sob o aspecto de um morfologista que a muitos parecia arraigado, era, na verdade, um conhecedor da biologia dos animais, que tão bem descrevia, e um trabalhador inveterado. Grande parte do seu tempo era empregada no interior do país para a busca de material de estudo e, por isso mesmo, a pessoa que melhor podia traduzir, para nós, os hábitos da gente camponesa. Foi um grande "mestre", formando escola do maior valor. Destaco, entre seus discípulos mais próximos, Teixeira de Freitas, Herman Lent, Souza Lopes e Sebastião de Oliveira.

Outro zoologista pelo qual nutri a maior admiração foi Gustavo de Oliveira Castro. Sua pouca produtividade, nascida da sua extensa curiosidade pelo mundo animal e vegetal, era compensada por uma erudição biológica, geral e especializada, que o tornava uma extraordinária fonte de informação para todos nós, estudantes, que dele nos aproximávamos. Dessa erudição dei-me conta quando prestei exames na disciplina de helmintologia. Haviam me dito, sem base, que Lauro Travassos me visaria caso eu não estivesse bem preparado. Passei uma semana com Gustavo de Oliveira Castro, quer no instituto, quer no laboratório de biologia animal do Ministério da Agricultura, situado na avenida Maracanã, revendo os métodos de diagnóstico de vermes. Fui muito feliz na prova, pois, dos dez exemplares dos quais deveria dar o gênero e a espécie, só errei um. Naturalmente, helmintologista mal preparado que era eu, não consegui identificar a espécie mais fácil.

É dificil traçar o perfil de um cientista a partir dos numerosos pesquisadores a que me referi. Devo, entretanto, salientar como fundamental a preparação básica que era a deles. Não uma preparação especializada ao detalhe, mas um conhecimento amplo do capítulo geral a que pertencia a disciplina que 
seguiam. De outro lado, quero fazer referência especial à persistência com que todos seguiam, ou para melhor dizer, perseguiam a hipótese de trabalho que os havia guiado no início de uma experimentação. Além do mais, diga-se que, malgrado divergências especiais, e certamente as houve, um esprit de corps a todos movia na defesa da instituição onde mourejavam. Certamente, uns seriam mais inteligentes do que outros. A alguns, uma intuição mais forte lhes facilitava o caminho, mas essas diferenças não se faziam sentir senão para aquele que as procurasse com esforço. Do mesmo modo, talvez alguns fossem mais vaidosos do que outros, mas, de maneira geral, a vaidade, sempre existente, justificava-se pela contribuição dada ao conhecimento científico.

Havia também, comum a todos, um grande poder de crítica, aplicado, de um modo geral, sem exageros, sem preferências, aos trabalhos de amigos ou não. Esse poder de crítica parecia-me sempre exagerado em relação aos trabalhos não originários de Manguinhos. Tomei conhecimento desse espírito de reserva nas ocasiões em que, levado por Carneiro Felippe ou Costa Cruz, ia almoçar na mesa à qual se sentavam, sempre, Astrogildo Machado, Júlio Muniz, o mais acerbo de todos, e Miguel Ozorio, o mais gracioso.

$\mathrm{O}$ almoço era servido no caramanchão cuja limpeza e aprazibilidade causavanos admiração. Muitos dos pesquisadores, entretanto, traziam de casa sua marmita e, assim, não compareciam ao caramanchão ou o faziam raramente. Um deles era Adolpho Lutz, por todos respeitado e admirado, e do qual se contavam episódios extraordinários de argúcia e hilariantes casos de esquecimento. Um desses, por exemplo, dizia do seu comparecimento ao instituto, durante os áridos verões que lá vivíamos, vestido com roupas de inverno. Acontecera que um termômetro doméstico havia-se quebrado e, na sua miopia, Lutz verificara apenas a presença de temperaturas baixíssimas na coluna de mercúrio e sua rígida disciplina suíça obrigara-o a seguir as indicações do termômetro. Durante anos meu pai ia buscá-lo na rua do Matoso para levá-lo a Manguinhos. Acompanhei-o várias vezes nessa missão, e era agradável ver Adolpho Lutz de longe, já fora do portão, consultando seu relógio de bolso, para verificar se não estávamos atrasados. Durante anos, também, meu pai levava o almoço de Lutz, pois minha mãe o preparava para ambos.

Outra figura fascinante, mas que pouco freqüentava o caramanchão, era Costa Lima, sempre de macacão azul, destoante das batas brancas usadas. Seu 
pequeno laboratório era constantemente o ponto de encontro, em torno das dez horas, para um cafezinho fresco. Costa Lima era um admirável causeur, ainda que muitas vezes a sua conversa descambasse para o picaresco. Era o que mais cedo chegava ao instituto, o que nos permitia fazer blague dizendo ser ele um passageiro usual do "trem das professoras". $\mathrm{Na}$ verdade, Costa Lima chegava cedo ao laboratório para dar início a uma atividade febril que só terminava a horas avançadas da tarde, o que lhe permitiu classificar insetos que vinham de todas as partes do mundo para o seu diagnóstico. Assim, pôde realizar seu sensacional trabalho Insetos do Brasil, em que os mesmos são descritos morfologicamente e analisados do ponto de vista do comportamento biológico. Ia eu conversar sempre com ele e não me lembro de ter deixado o seu laboratório sem ter apreendido alguma coisa de ciência ou de como se faz ciência.

Um outro exemplo do que era a vida de Manguinhos e a severidade com que os neófitos podiam ser tratados ocorreu com Gomes de Faria De alta estatura e olhos amendoados, Gomes de Faria era uma verdadeira enciclopédia científica. Foi ele quem primeiro me ensinou os elementos de enzimologia em aulas paralelas às do curso do instituto. Sua projeção científica era de tal ordem que foi convidado por Fonseca Costa a criar um departamento de bioquímica e fermentação no Instituto Nacional de Tecnologia. Freqüentemente ia vê-lo para discutirmos sobre o que eu estava fazendo. Era muito severo nas críticas, o que foi de grande proveito para mim. Lembro-me, de uma feita, que trabalhei todo o fim de semana em preparações de figados de amarelentos, tentando obter uma nova coloração para a identificação dos lipídios na célula hepática. Num domingo, à tarde, achei que havia obtido as preparações ideais e, imbuído do meu sucesso, levei uma das lâminas para Gomes de Faria examiná-la. Expliquei toda a técnica usada e, por fim, coloquei minha preparação no microscópio. Gomes de Faria observou-a durante algum tempo; levantou-se, pegou a lâmina, quebrou-a ao meio, colocando na cesta de lixo os dois pedaços. Virou-se para mim, que estava com os olhos cheios de lágrimas, e disse: "Não se incomode, meu caro, com o que fiz. Você ainda tem que aperfeiçoar muito o seu método para poder apresentá-lo a alguém." Semanas mais tarde, consegui uma preparação melhor e vi como tinham sido justas as suas observações, as quais, de modo abrupto, fizeram com que eu recomeçasse o trabalho. 
Pensando em todos esses mestres com os quais convivi, mais se solidificou, em meu espírito, o conceito de que a ciência busca a verdade. Esta se faz seja por um contato permanente entre o pesquisador e o objeto inquirido, seja, como nas ciências históricas, com uma separação entre os mesmos, no tempo e no espaço. É óbvio que esse conhecimento se torna válido pela aplicação de métodos que, muitas vezes de caráter geral, apresentam aspectos específicos na abordagem de tal ou qual hipótese. Diga-se, aliás, que essa busca de conhecimentos a partir de uma "informação" é a base da hipótese a ser perseguida. Essa informação tem várias fontes, muitas das quais se passam na esfera do subconsciente, mas, qualquer que seja o ritmo da busca desses conhecimentos, deve-se levar em consideração que não pode ela se firmar somente na procura de uma possível verdade, em que a hipótese inicial se transformou, ou então ser formulada a sua busca em condições que não correspondam à realidade contingencial em que vive o pesquisador. Isto poderia ser expresso de uma maneira mais simples, dizendo-se que a busca do conhecimento por meio de uma hipótese deve-se abrir para horizontes imprevisíveis na formulação inicial do processo, isto é, não se deve querer buscar o que se deseja, e sim o que a realidade nos fornece. Mesmo nos países em condições econômicas precárias, o trabalho a ser realizado deve levar em consideração as mesmas condições. Isto exige, por parte do pesquisador ou dos grupos de pesquisa, uma análise cuidadosa das suas possibilidades experimentais e intelectuais, para que não haja desperdício material e enfraquecimento do potencial humano.

Desse tempo de Manguinhos guardo, com especial carinho, a recordação das minhas idas à biblioteca. Dirigida por Overmeer, que Oswaldo Cruz trouxera da Holanda, a biblioteca era um assombro de riqueza bibliográfica. Nela permanecia longas horas examinando revistas de fisica, química e biologia, que só ali podiam ser encontradas. Cito, como exemplo, os Annalen der Physik. Neles encontravam-se os mais significativos artigos que haviam provocado algumas das principais revoluções científicas de todos os tempos, como a que se processou, por exemplo, antes da Segunda Guerra Mundial, na fisica teórica e experimental. Esses artigos me interessavam muito, não só porque me preparavam para melhor compreender as conversas com Carneiro Felippe, como também me davam um baseamento histórico indispensável ao conhecimento mais perfeito de qualquer disciplina científica. Overmeer 
verificava com cuidado se eu não estava surnupiando, para levar para casa, um exemplar da biblioteca, e só depois de ter constatado que eu, disciplinadamente, não o fazia (mesmo porque, simples estagiário e, mais tarde, assistente, não tinha tal direito), mostrou-se extremamente cordial, auxiliandome a encontrar muitos dos volumes que eu procurava. Por causa do seu espírito disciplinador e, talvez ainda, pela pouca facilidade no manejo do português, pintava-se Overmeer como um aterrador guarda de livros. Era, sim, um protetor dos mesmos e, estou certo, se não fosse sua vigilância e seu rigor, a biblioteca do Instituto Oswaldo Cruz não teria se transformado na grande instituição que todos admiramos.

Quero também assinalar a extraordinária assistência que me deu um dos varões mais completos que conheci: Joaquim Venâncio. Natural de uma fazenda de minha avó, veio cedo para o Rio e meu pai o empregou com acerto no Instituto Oswaldo Cruz. Desde o primeiro dia em que fui a Manguinhos, Venâncio me mostrou todos os detalhes do prédio e acompanhou-me por toda a parte. Era uma espécie de babá que me protegeu durante anos. Pouco a pouco tornou-se um conhecedor dos variados animais que eram utilizados nas experiências dos pesquisadores. Trabalhando com Adolpho Lutz, dele se conta que podia reconhecer a espécie de uma rã pelo seu coaxar. A pessoa de Venâncio é a demonstração das possibilidades imanentes que existem em todas as camadas sociais de nosso país.

Em Manguinhos, eram de excepcional valia os serviços auxiliares iniciados por Oswaldo Cruz, que havia trazido artesãos do maior quilate, até da Europa. A mecânica de alta precisão, a indústria de vidro, a capacidade de projetar circuitos elétricos, e tudo o mais que compõe a infra-estrutura de um estabelecimento científico era provido do que de melhor se possa imaginar. Direi, ainda, que esses artesãos pertenciam a grupos familiares que deram ao mundo científico nacional um exemplo de capacidade e de desprendimento. Certamente, uma das alavancas que asseguraram a ascensão científica do instituto foi o auxílio dado aos seus pesquisadores pelo grupo de técnicos, especialistas de variados matizes, que ali labutaram e, até mesmo, ali se formaram. Não há instituição científica que possa viver sem esse grupo de colaboradores nunca bem compreendido por nossas autoridades governamentais, que sempre lhe negaram a remuneração compatível com a qualidade do seu trabalho. 
A dificuldade de dar aos técnicos e auxiliares um nível adequado de salário e até um tratamento mais humano, no dia-a-dia, foi uma das constantes preocupações que tive durante minha vida. No entanto, os resultados obtidos eram sempre frustrados pela rigidez das normas burocráticas e administrativas e que sufocam a vida da pesquisa no Brasil. Disto resultou sua evasão para o setor particular. Eu mesmo tive a amarga experiência de preparar técnicos auxiliares, até mesmo enviando-os ao estrangeiro, para vê-los, depois, deixarem o Instituto de Biofisica atraídos por outras entidades que lhes garantiam condições que a universidade não podia assegurar. Acho que uma das grandes diferenças entre a nossa ciência e a do mundo industrializado é que, em nosso país, não se oferecem as condições econômicas e sociais que os artesãos científicos merecem.

A perfeição que testemunhei no preparo de soro antipestoso, ou no trabalho de vidraria - que deu origem às fábricas de ampolas no Brasil - , era absoluta. Também assim era a mecânica fina, que se podia ali fazer com o auxílio de Júlio Grimaldi. Com ele consegui, nos albores da minha carreira experimental, construir o pequeno difrator de elétrons destinado a estudos cristalográficos. Foram estes descontinuados quando fui forçado a me preparar para o concurso da Faculdade de Medicina. Qualidade artesanal como a que havia em Manguinhos só vim a encontrar, muito mais tarde, quando comecei a conhecer os laboratórios do Primeiro Mundo.

Havia um laço de afeição e amizade entre pesquisadores, técnicos e artesãos. Entretanto, só raramente figuravam estes últimos como co-autores dos trabalhos publicados, quando muitas vezes o eram. Tal reconhecimento eu vi na Grã-Bretanha, onde os principais trabalhos de Archibald V. Hill eram assinados, também, pelo extraordinário mecânico que the preparou os minúsculos pares termoelétricos e construiu os galvanômetros ultra-sensíveis, que permitiram a determinação da quantidade de calor produzida no nervo pela passagem do impulso nervoso.

A perplexidade pela morte de meu pai, em 1934, fez-me refletir sobre a permanência, ou não, na instituição que considero a minha alma mater. Não que eu gozasse de privilégios especiais por ser filho de Carlos Chagas $O$ único, talvez, tenha sido o meu contrato para auxiliar de assistente - sem prejuízo para nenhum outro pretendente - obtido pelas normas que levavam a essa contratação, pelo estágio científico ali realizado e pela aprovação no curso, ao 
que se poderiam juntar minha atividade no Hospital Evandro Chagas, em Manguinhos, e meu trabalho positivo no Serviço de Anatomia Patológica do Hospital São Francisco de Assis. Creio que, de um modo geral, a minha contratação foi bem aceita, pois que não houve pronunciamentos contra a mesma. Dedicava meu tempo, quase integralmente, ao instituto, interrompido apenas três vezes por semana para dar aula de hematologia, normal e patológica, no curso de anatomia patológica da Faculdade de Medicina, ministrado por Leitão da Cunha. As aulas iam de meio-dia e meia a uma e meia, o que me obrigava a ir ao instituto pela manhã, seguir para a praia de Santa Luzia, no chamado Instituto Anatômico, e retornar a Manguinhos. Isso só podia ser feito graças às facilidades do tráfego na época e graças ao fato de ter podido comprar a linda Fiat conversível, minúscula, conhecida como "Balilla", tipo 514, com o dinheiro que havia ganho em 1931 com o Prêmio Dona Antonia Chaves Berchon des Essarts, e mais seis contos de réis, emprestados por um tio. Embora de segunda mão, o carro custou-me doze contos de réis.

Quero ainda me referir às características de duas figuras com quem muito convivi. Magarinos Torres era o "operário" da ciência. Sentava-se à sua mesa e, com a paciência de um monge, estudava, lâmina por lâmina, os resultados histológicos de autópsias praticadas nos dias anteriores. Era um homem simples, mas de extraordinária compostura científica. Raramente eu o vi voltar atrás na conclusão de um diagnóstico, mas se tivesse que fazê-lo o faria cem vezes, pois admitia, com facilidade, os seus erros - um exemplo que seguíamos - ainda que escassíssimos e, na maioria, resultantes do descuido com que a preparação histológica havia sido feita por mim ou por outro qualquer dos seus ajudantes.

Em oposição à economia de palavras com que Torres nos explicava um quadro macroscópico ou um detalhe de uma preparação, Osvino Pena era um expositor extraordinário. Alto, cabelos bem implantados, deixando, todavia, aparecer a sua larga testa, tinha a voz de um tribuno. Falava com simplicidade, embora nela se percebesse sua extraordinária erudição; fazia-o, entretanto, sem jactância. Profundo conhecedor de fisiopatologia, muitas vezes o ouvi, ao redor da mesa de necropsia, explicar aos clínicos presentes, deixando-os perfeitamente à vontade, as razões dos erros cometidos no diagnóstico a que haviam chegado. No entanto, não magoava ninguém. Eram pequenas dissertações nas quais 
recordava a fisiologia normal e os mecanismos de sua perturbação patológica. Deixava-me sempre atônito pela simplicidade e qualidade de suas exposições.

No Setor de Anatomia Patológica trabalhei, ainda, com duas grandes figuras: Burle de Figueiredo e Penna de Azevedo. Burle de Figueiredo distinguia-se pela simplicidade de suas explicações e pela qualidade das preparações histológicas que ele próprio fazia, introduzindo sempre métodos novos. Elegante, sem exageros, me encantava voltar de Manguinhos a seu lado, na sua Lancia conversível. Aproveitávamos a carona para discutir os aspectos mais interessantes das atividades do dia. Penna de Azevedo, mais moço do que os outros, tornou-se o bom companheiro a quem eu recorria a cada dúvida que me aparecia. Sempre cortês, Penna de Azevedo tinha grande paciência para esclarecer e entretinha-se comigo na explicação do seu importante trabalho sobre a tripanossomíase americana.

Os estudos médicos continuaram numa divisão imperfeita entre as aulas da faculdade, sempre marginalizadas, e os trabalhos no São Francisco e em Manguinhos, os quais assumi com toda a regularidade.

A vida, dividida entre o instituto e a faculdade, ainda me dava tempo para o lazer. Ao esporte sempre dei preferência e, durante certo tempo, dediqueime ao remo, que deixei por ter que me levantar muito cedo para chegar à garagem do Clube de Regatas Guanabara. O cinema era quase uma ocupação, mas devo confessar que nunca fui capaz de guardar o nome dos diretores, o que me caracterizava como um amador - aquele que se lembra de um filme pelo nome do ator principal. Houve momentos em que me dediquei seriamente ao bilhar. Jogava sinuca num salão da rua São José, defronte à estação de bondes, hoje ocupada pelo Edificio Avenida Central. Muitas vezes deixei o salão bem passadas as doze horas da noite. Eram meus companheiros vários colegas, mas o grande jogador, sem dúvida, era Walter Oswaldo Cruz, também campeão de xadrez.

Politicamente, o último ano da faculdade foi muito agitado. A população do Rio, influenciada por líderes de alta expressão oratória, como Maurício de Lacerda, que haviam substituído líderes mais velhos, como Irineu Machado e até mesmo Paulo de Frontin, mostrava-se cada vez mais contrária a Washington Luís. Este, na expressão demagógica de muitos, nada mais era do que a representação da plutocracia paulista. De outro lado, o movimento da Aliança Liberal arrancava mais simpatias pela imagem que se formara de Antônio 
Carlos de Andrada e Silva, então governador de Minas, e Getúlio Vargas, que havia abandonado a pasta da Fazenda do governo Washington Luís para ser governador do estado do Rio Grande do Sul. Minha casa, sempre muito visitada por mineiros de grande quilate, era um centro de discussões sempre favoráveis à Aliança Liberal e ao doutor Getúlio Vargas.

Nós, estudantes, várias vezes saímos às ruas em manifestações de desapreço ao governo. Ocupada a avenida Rio Branco, éramos, depois de um semnúmero de discursos, as mais das vezes inflamados e sem muito conteúdo, contidos pela Polícia Montada. Salvavam-nos da espadeirada os donos das casas de comércio que, sabiamente, se protegiam com portas semicerradas. A maioria dos jornais era oposicionista e estava a auxiliar o movimento antigovernista. Apporelly, o Barão de Itararé, lançava, semanalmente, um jornalzinho, $A$ Manha, que fazia o gáudio dos oposicionistas.

No dia 24 de outubro de 1930 tive uma experiência única. Acordei de madrugada com uma zoeira incrivel. Minha avó, guerreira de quatro costados, já estava na janela da frente quando ali cheguei. Eram tanques do Exército que iam ao Palácio Guanabara para depor Washington Luís. Vesti-me às pressas e saí correndo na mesma direção. Por um acaso feliz encontrei, na esquina de Paissandu com Guanabara, o tenente Mena Barreto, que comandava um batalhão revoltado. Conhecia-o do tempo em que tirei a minha carteira de reservista. Simpatizara comigo na ocasião do exame oral imposto aos estudantes de medicina que haviam vaiado um batalhão do Terceiro Regimento, sediado na Praia Vermelha. As reprovações eram freqüentes e eu não sei como consegui responder às perguntas que me foram feitas. Isto me deu um certo prestígio com os oficiais examinadores e Mena Barreto não se esquecera de mim. Convidou-me para entrar, o que fiz subindo até o andar nobre do palácio. Ali encontrei vários políticos da situação, que pareciam em desespero. Alguns deles eu conhecera na minha própria casa. Sobressaía, entre os agitados políticos que ali estavam, a calma de Otávio Mangabeira, que parecia estar aconselhando a todos que tivessem uma atitude mais ponderada. Como eu o conhecia, trocamos algumas palavras. Perguntoume o que eu estava fazendo lá. Contei-lhe o episódio que ali me levara e o seu conselho foi simples: "Logo que puder, volte para a sua casa porque o ambiente aqui pode se tornar violento." Não segui o conselho de Mangabeira e continuei perambulando pelos salóes quase vazios do palácio. Alguns estavam 
fechados e eu sabia que era o local onde Washington Luís, com alguns dos seus ministros e poucos amigos, havia se refugiado. Num certo momento, ouviu-se um rumor vindo do exterior do edificio: as tropas se movimentavam, pareceu-nos a todos. Na verdade, o que acontecia era que as tropas que fechavam a entrada do palácio estavam abrindo espaço para a chegada do cardeal Leme, que se propunha a intermediar uma solução para o conflito. Depois de muita discussão resolveu-se que, na companhia do cardeal, Washington Luís iria para a fortaleza de Copacabana. Eu, já meio enfarado do que via, fui-me retirando, mas não sem assistir a uma das cenas mais emocionantes da minha vida. Encontrava-me no meio da escada que desce ao térreo, a do lado esquerdo de quem olha para o palácio, quando vi Washington Luís aparecer acompanhado do cardeal e de um certo número de pessoas. Encostei-me na parede para deixar o cortejo passar. Notei, logo de início, um fato impressionante que mostrava o desagrado de Washington Luís. Caminhava sempre um passo à frente do cardeal Leme, com quem não trocou palavra. Mais ainda: no patamar que divide a escada em dois lances, um jovem oficial de Marinha, creio que ajudante-de-ordens do presidente, dele se aproximou e quis se ajoelhar para beijar a sua mão. Com energia, mas discretamente, Washington Luís evitou o episódio e sussurrou ao referido oficial palavras que muito o sensibilizaram e o levaram às lágrimas. Em seguida, Washington Luís desceu o resto da escada e entrou no carro que já o esperava e em cujos estribos se aboletaram quatro oficiais do Exército. A tristeza do episódio tão dramático foi tal que me dirigi logo para casa, onde relatei a minha avó tudo o que tinha visto. Ela, no seu exagero florianista, sorria de satisfação com o que eu lhe contava.

Meu entusiasmo pela revolução durou pouco. É que meu pai, que estava na Europa em missão junto ao Comitê de Higiene da Liga das Nações, regressou antecipadamente ao Rio (novembro de 1930). Fomos todos esperálo no cais e qual não foi nossa surpresa quando não o vimos descer junto com minha mãe e os outros passageiros. Um médico da Saúde dos Portos chegou, apressadamente, para nos dizer que meu pai havia descido na lancha da Polícia Militar e tinha ido diretamente para a Quarta Delegacia Auxiliar. Seguimos todos para casa, onde algumas horas depois chegou meu pai, muito cansado e bastante magoado. Fora ele liberado por Afrânio de Mello Franco, ao qual um amigo comum avisara do ocorrido. A prisão de Chagas, ainda que 
temporária, era injustificada, não só pela probidade de sua vida, como também pelo fato de que Chagas se havia mostrado, desde cedo, ardente adepto da Aliança Liberal. É bem claro que, em momentos de perturbação social, denúncias se acumulam para prejudicar inimigos. No caso de meu pai, ao que se apurou, ainda que imprecisamente, fora a denúncia de um médico que o levara a ser considerado suspeito e perigoso pelo governo revolucionário. Esse médico, membro da Academia de Medicina, não podia perdoar meu pai por ter ele, como diretor do Departamento Geral de Saúde Pública, mandado fechar seu consultório, no qual era associado a um charlatão alemão que prometia a cura da hanseníase. O episódio, sem dúvida, marcou muito a vida de meu pai. Todos nós ficamos extremamente constrangidos e sem meios de levantar o protesto que desejávamos. Na verdade, Getúlio Vargas não manifestava, na ocasião, grande entusiasmo por meu pai. É que um dos companheiros deste, escolhido para um cargo importante na direção do Departamento Geral de Saúde Pública, levara meu pai a exonerá-lo do cargo de confiança, por causa dos repetidos pronunciamentos contra o governo de Artur Bernardes. Afastado da função que tinha, malgrado a sua capacidade, passou a exercer a assessoria do governo do estado do Rio Grande do Sul e, portanto, ligado diretamente ao novo presidente da República. Certamente tinha ele influenciado Vargas em relação a meu pai. Logo depois de sua subida ao poder, Getúlio Vargas quis substituir o velho Chagas na direção do Instituto Oswaldo Cruz, pretendendo nomear, para o mesmo, um eminente cirurgião de São Paulo, doutor Sérgio Meira, que chegou a vir ao Rio, na companhia de alguns de seus conhecidos, para visitar o Instituto de Manguinhos. Foi Luiz Simões Lopes, a que tudo indica, quem o demoveu do propósito.

Passavam-se os dias e formou-se um movimento estudantil contra o qual me opus e que, na verdade, me tornou impopular. É que os estudantes de medicina e de outras entidades de ensino médio e superior haviam obtido, do novo governo, um decreto que permitiria ao aluno passar de um ano para o outro sem a prestação de exames. Isto nada mais era do que a repetição, numa analogia sem base, do decreto promulgado logo depois da epidemia de gripe espanhola. Eu me opus à nova "promoção por decreto". Meu pai, entretanto, pediu-me que não prestasse exames para não me indispor com meus colegas. 
Iniciado o ano de 1931, renovei o meu estágio em Lassance, mas a partir de junho, quando retornei ao Rio, comecei a me preocupar com o fim do ano, que marcaria o término da minha carreira acadêmica. Creio que esse sentimento tomou conta de todos os meus colegas de turma - e será assim mesmo, nos dias atuais -, ainda que, na ocasião, o mercado de trabalho médico fosse de mais fácil acesso do que é hoje.

Essa sensação de incerteza sobre o futuro mais se agravava à medida que o tempo corria, tanto mais que, numa homenagem que me pareceu descabida, resolveram meus colegas, e o conseguiram, que a nossa formatura fosse realizada no dia 31 de outubro, data que marcava o primeiro aniversário da revolução vitoriosa. Eu deveria ser o mais calmo, pois tinha garantida a minha presença como estagiário no Instituto Oswaldo Cruz, assim como acontecera, cinco anos antes, com meu irmão Evandro, que pôde abrir a porta de sua carreira profissional sem qualquer dificuldade. Meu caso era uma exceção, mas a situação para muitos de meus colegas poderia parecer duvidosa.

Não me emocionei no dia da formatura. Ao contrário, achei a solenidade um pouco oca, tendo em vista que o discurso do nosso paraninfo, o professor Juvenil da Rocha Vaz, me pareceu medíocre. Rocha Vaz fora, no governo Bernardes, um dos grandes homens da medicina, tendo exercido, além da clínica numerosa, várias funções significativas. Foi, simultaneamente, diretor da Faculdade de Medicina, reitor da Universidade do Brasil - como então se chamava a Universidade Federal - e mentor do Conselho Hospitalar. Tinha em mãos um grande poder. Exercia suas atividades com critério, mas sem grandes iniciativas, penso. Era professor da Faculdade de Medicina, nomeado em conseqüência da reforma, em 1925, que levou o seu nome. Fizemos parte, assim, da sua primeira turma de alunos. Com ele discuti inúmeras vezes, porque não aceitava a sistemática e rígida utilização da biotipologia que Viola criara na Itália e da qual Nicola Pende, endocrinologista de renome, era o grande arauto. Pende era um viajante que, sob as ordens de Benito Mussolini, percorria o mundo e, particularmente, a América Latina, para difundir as idéias de Viola e as excelências da medicina italiana protegida pelo ditador fascista. Com Rocha Vaz tive vários pequenos entreveros, no período em que tentei mostrar a ele a impossibilidade de ajustar os doentes de moléstias infecciosas, como doentes de febre tifóide, aos paradigmas da biotipologia. Creio que Rocha Vaz nunca se agastou com as minhas críticas 
à biotipologia, exageradas como a de qualquer jovem. Pelo contrário, foi extremamente cortês quando fiz o meu concurso para catedrático. Era ele o diretor da faculdade.

Muito interessante e de boa qualidade intelectual foi o discurso do nosso orador, Luís Novelli. Calmo, com idéias bem construtivas e em muito bom português, Novelli esteve bem acima e longe dos vários discursos de doutorandos, todos eles rebarbativos, e muitas vezes insolentes, com caráter de plataforma política e não de exposição de idéias.

À formatura seguiu-se um baile realizado no Automóvel Clube, na rua do Passeio. Envergávamos o traje a rigor, para alguns quase um suplício e, com dificuldade, mantinha-se a gravata preta no lugar. A grande maioria, entretanto, estava muito bem posta e parecia ser o smoking o traje de todos os dias. As moças eram lindas. Vinham de todos os cantos da cidade e de vários pontos do país. Vestidos novos, cores as mais variadas, faziamme lembrar a descrição de Proust em uma passagem de Em busca do tempo perdido. Cada um dos formandos trouxera sua mulher ou sua namorada, ou aquela dama especialmente convidada para a grande noite. Eu me fiz acompanhar de uma das moças mais finas do Rio, filha de um professor da faculdade, o que permitiu a muitos dos meus colegas pensar que ela fosse a minha noiva. Noite estupenda! A alegria do baile e a ofuscante beleza das moças fizeram com que muitos de nós, senão a totalidade, esquecêssemos que o "amanhã" representaria, na verdade, o começo de uma nova vida.

Esse período final na faculdade foi marcado por encontros importantes para mim. Com Freud, por exemplo, cuja obra foi-me dada a ler por Branca de Almeida Fialho. Li com garra os dois primeiros volumes, os que tinha, mas ficou-me da leitura um misto de admiração e de desconfiança. Admiração comum a todos os que lêem, com atenção e sem preconceitos, os livros do extraordinário neurofisiologista, psiquiatra e filósofo vienense. Desconfiança que persiste em pequena dose, até hoje, pelo fato de não encontrar uma base organicista naquelas maravilhosas páginas que havia lido. Este é um tema presente com freqüência no meu pensamento e, até mesmo, em discussões familiares, e flutua no meu espírito a vontade de saber como fazer a ponte entre o conhecimento do psiquismo e os avanços da biologia moderna. Dele tiro um conceito que me diz que não se deve 
rejeitar, por princípio, o que não lhe agrada, seja por preconceitos, idéias diferentes, ou sentimentos que nada têm a ver com o racionalismo científico.

O outro encontro foi com o marxismo. Não consegui absorver certos princípios fundamentais que vieram depois a se popularizar. Também nunca soube nem pude tomar uma atitude antimarxista irredutivel. Ao contrário, muitas vezes procurei me ajustar a certas verdades da teoria marxista que são tão óbvias que não podem ser, de modo algum, rechaçadas. Porém, o que mais me atraía no marxismo era o apoio dado à ascensão sócio-econômica dos desprotegidos e dos marginalizados. Nunca fui influenciado, na minha posição, por motivos religiosos, porque a minha completa adesão ao catolicismo veio muito mais tarde, por influência das aulas de frei Secondi e da leitura de Santo Tomás de Aquino.

Tive, também, a ajudar-me na formação do meu espírito, alguns amigos de preciosa convivência que vieram completar o que meu pai, Evandro e Hélio Lobo me haviam ensinado. Além de Almir Castro e Tito Leme Lopes, meus colegas de turma, vim a conhecer e conviver com Álvaro Vieira Pinto, Plínio Sussekind da Rocha e outros. Com eles tomei conhecimento de pontos de filosofia - que eu não havia apreendido - , de história e, principalmente, de poesia, música e literatura, completando, assim, a minha personalidade. Mais tarde, seria ela burilada pelos meus mestres de Manguinhos e por personalidades como Bernanos, René Wurmser, Odilo Costa, filho, Afrânio de Mello Franco, meu sogro, e Virgílio de Mello Franco, entre outros.

Logo depois de nossa formatura, um movimento político de grande envergadura, a revolução de São Paulo contra o regime imposto por Getúlio Vargas ao Brasil, tomou conta do meu espírito. Em nossa casa, a começar por minha avó Maria, a guerreira, todos nos filiamos à corrente pró-paulista. Por causa disso e das minhas posições muito fortes a favor de São Paulo, ao que se sabe, discutiu-se muito, de novo, no Palácio Guanabara, a exoneração de meu pai da direção do Instituto Oswaldo Cruz. Em determinado dia, fiquei horas no Café Amarelinho com um grupo que eu não conhecia, esperando o momento em que nos seriam fornecidas armas para tomar o Ministério da Educação. O governo, mal informado, pensou que fosse meu pai o envolvido no movimento. Fui, com centenas de estudantes, espadeirado numa manifestação na avenida Rio Branco. Estava eu tão fascinado pelo movimento que, um dia, levei ao embaixador Ciro de Freitas Vale o meu 
anel de formatura, que fora de meu pai, para ser entregue àqueles que recolhiam recursos para assegurar a vitória das forças paulistas. Data de então, creio, o deslumbramento que tenho por São Paulo, sua gente e suas instituições.

Encerrado o episódio, a vida voltou ao que era, e as minhas atividades continuaram a se dividir entre Manguinhos e a Faculdade de Medicina. Nesta eu havia mudado de direção. Deixara a cadeira de anatomia patológica e conseguira minha transferência para a de física biológica, onde fui carinhosamente recebido por Francisco Lafayette Rodrigues Pereira, seu titular. Diferentes em muitos aspectos, Leitão da Cunha, meu primeiro chefe, e Lafayette tinham, entretanto, traços comuns. Ambos eram extremamente atentos às atividades de suas cátedras, as quais exerciam com extrema pontualidade. A diferença entre eles encontrava-se no trato dado aos seus amigos e interlocutores; enquanto Leitão da Cunha, extremamente cerimonioso, mantinha-os a uma certa distância - com ráíssimas exceções Lafayette era de uma irresistivel bonomia, simples, acessível, e um grande apreciador de conversas. Ao sair da faculdade, na Praia Vermelha, ia para a cidade onde, primeiramente, fazia ponto na Livraria Odeon, fornecedora da grande biblioteca particular que mantinha em sua casa no início da rua Voluntários da Pátria. Depois, ia a um café na esquina da avenida Central com a rua São José, onde encontrava-se com vários amigos e, inclusive, discípulos, para um inesgotável bate-papo, aos quais trazia sua contribuição contando casos da história da faculdade, de sua passagem por Minas Gerais, ou da história das ciências. Sua extraordinária erudição era devida, penso, ao longo tempo em que exerceu, logo depois de formado, as atividades de radiologista em São João del Rei. Nesta cidade fez amizade com José Carneiro Felippe, que havia terminado o curso na Escola de Minas de Ouro Preto. Ali fora residir com o intento, logo fracassado, de se tornar um comerciante de minérios de ferro. Em São João del Rei, Lafayette preparou o seu concurso para professor na Faculdade de Medicina, que certamente deixou eco na história da faculdade. Com um único adversário, Miguel Ozorio de Almeida, as opiniões da sociedade médica eram de que o jovem especialista interiorano não podia competir com um dos mestres mais renomados do nosso mundo intelectual. Foi assim, com surpresa, que o voto da congregação - que na ocasião era elemento votante no julgamento dos concursos - consagrou Francisco Lafayette. Este, franzino, com a voz embaçada por uma rouquidão 
que existiu até o seu falecimento, esteve sensacional na sua exposição oral, tratando de um assunto que parecia muito dificil a todos, "o segundo princípio da termodinâmica", com uma simplicidade e uma inteligibilidade que a todos encantou. Essas características eu as encontrei nas múltiplas vezes em que conversamos no laboratório, em sua casa, ou até no café da cidade, quando me fizeram compreender a teoria da relatividade e os novos avanços sensacionais da fisica atômica. Ao assumir a cátedra, Lafayette soube que o professor de fisiologia não se interessava por instalar uma sessão experimental em sua cátedra e recusara um donativo vultoso na ocasião. Lafayette resolveu utilizar essa doação e, no seu desprendimento, embarcou acompanhado da mulher, dona Odette, às suas próprias custas, para a Europa, onde comprou todo o material que enriqueceu extraordinariamente o acervo do seu laboratório.

Minha atividade inicial consistiu, essencialmente, em dar o curso de fisica aos alunos do curso de farmácia, anexado à Faculdade de Medicina, o que me foi de extremo proveito, pois aprendi a dar aulas, uma constante preocupação em toda a minha vida, tarefa que procurei melhorar a cada dia. Devo dizer que muito aprendi com meus alunos, pois o verdadeiro processo de ensino é a reciprocidade com que mestres e alunos se entretêm.

Nos anos a que acabo de me referir dei início à atividade de pesquisa. No fim de algum tempo publiquei o meu primeiro trabalho, muito simples, sobre o que se chamava "condução elétrica nuclear". Deixou muito a desejar, pois não realizei as contraprovas indispensáveis à grande maioria dos trabalhos experimentais, senão à sua totalidade. Tive um momento de imensa alegria e emoção - que todo iniciante deve sentir - ao vê-lo citado, com imerecida ênfase, em um tratado alemão de bioeletricidade. 


\section{IV}

\section{Cátedra}

$\mathrm{F}^{\mathrm{m}}$ fevereiro de 1936, fui chamado ao telefone, em Manguinhos. Recebi assim a notícia que me estarreceu: Francisco Lafayette havia morrido. Sabia que a sua situação pulmonar se havia agravado, mas estava longe de pensar em um desfecho mortal. Não me lembro de como caminhei do telefone, situado no edificio central, ao laboratório. Mais tarde, passado aquele primeiro momento de choque e emoção, julguei que seria apropriada a indicação de Miguel Ozorio, em plena forma, para substituí-lo. Telefonei para Branca Fialho e ela se entusiasmou, evidentemente, com a idéia, que fracassou porque a congregação da Faculdade de Medicina recusou-se a validar o concurso de Miguel Ozorio, feito vinte anos antes. Os argumentos que dei a Pedro Pinto, o professor mais influente no Conselho Técnico-administrativo, de nada valeram. Disse-me ele que haveria concurso e que eu deveria me preparar para o mesmo. Aliás, minha inscrição só era permitida porque eu havia, meses antes, prestado o concurso de livre-docente e, assim, podia, pelo regulamento, concorrer sem ter completado seis anos de formado. Todos os meus amigos insistiram para que eu me preparasse para o concurso; resolvi, pois, encarar seriamente essa hipótese e fiz um plano de estudos que pôde ser executado graças ao fato de as provas só terem sido realizadas quase dois anos depois do falecimento de Francisco Lafayette.

Para preparar-me em exercícios práticos de fisica, freqüentei, quase diariamente, o laboratório de fisica da Escola Politécnica, onde tive como professor Joaquim da Costa Ribeiro, um dos mais nobres homens que 
encontrei na vida. Foram noventa e dois exercícios, em parte repetidos no laboratório da Praia Vermelha. Para dominar o setor de eletricidade e medidas elétricas, ancorei-me na pessoa de Francisco de Oliveira Castro e freqüentei, durante mais de um mês, o laboratório de medidas elétricas que Oliveira Castro havia montado, para satisfação de Marinho de Azevedo, professor da disciplina na Escola Politécnica.

Estudava pelo menos cinco horas por dia, entrando, muitas vezes, noite adentro. Morávamos na rua Jardim Botânico, 230, em uma casa muito aprazivel, que se tornou um centro de atração para muitos amigos. Assim é que, quase diariamente, ali iam ter Vinicius de Moraes, Manuel Bandeira, José da Frota Moreira, Almir Castro e outros mais. Discutiam, conversavam, tocavam violão e cantavam, enquanto eu me aferrava aos livros. Foi esta a parte mais dificil da minha preparação. Metia-me no escritório, no andar superior, mas não podia deixar de ouvir o ruído da conversa dos amigos na sala de visitas. Às vezes, uma canção entoada por Vinicius atravessava com facilidade as paredes e o chão, e isso era mais do que uma razão para que eu perdesse o compasso com o que estudava. Entretanto, eram sempre momentos de encanto e, até hoje, escuto a voz carinhosa e quente de Vinicius pedindo "à Lua branca de fulgores e de encanto" que enxugasse as suas lágrimas de poeta. Era-me dificil retornar ao estudo e só depois de alguns minutos é que a concentração tomava conta de mim.

Nessa ocasião, organizei uma biblioteca de livros especializados que muito me ajudaram. Na sua realização tive o grande auxílio do senhor Eric Eichner, dono da Livraria Alemã, de uma só porta de entrada, na rua da Alfândega. Encomendou da Europa os livros de que eu necessitava e, principalmente, permitiu-me acumular uma conta de quatorze contos, que só pude saldar recebendo atrasados de quase um ano do Instituto Oswaldo Cruz. A minha prova oral foi considerada muito boa e baseou-se na repetida leitura de um tratado francês sobre hidrodinâmica. Há, dessa época, um episódio muito interessante. Entrava eu na Faculdade de Medicina com vários livros debaixo do braço, quando me deparo com Pedro Pinto. Depois de uma amena troca de palavras, Pedro Pinto virou-se para mim e disse: "Vou lhe dar um conselho, que tiro de Santo Agostinho: eu só temo o homem de um só livro." Conselho prudentíssimo que me fez concentrar no estudo de três ou quatro dos dez volumes que havia adquirido. 
Houve grande dificuldade na escolha da banca do concurso, pois foram declarados suspeitos Miguel Ozorio de Almeida e Baeta Vianna, sob a alegação de serem meus amigos. Afinal, com seis candidatos, fez-se o concurso, durante o qual houve turbulências, pois um dos candidatos, meu companheiro na cátedra, acusou a mesa de me proteger, assegurando que os pontos listados para o sorteio eram assuntos de minha preferência.

Minha prova oral teve numerosa assistência. Na véspera, havia eu feito um ensaio geral, em casa, com a presença de Carneiro Felippe, que se mostrou muito preocupado, pois eu havia gasto mais de hora e meia, quando o tempo estipulado era de cinqüenta minutos não prorrogáveis. Ajudaram-me na preparação da prova oral Pedro Nava e Paulo de Carvalho, mais tarde professor de farmacologia. A eles coube a feitura dos dezesseis quadros que exibi durante a prova. Encerrei-a exatamente aos cinquienta minutos, com o último dos desenhos preparados. Carneiro Felippe exultou com a precisão que consegui dar ao assunto tratado.

Na prova escrita também fui feliz e apresentei o assunto com a concisão que se encontra no livro Thermodynamics, de um autor inglês, E. Guggenheim. Terminadas as provas, tive que esperar três dias para saber o resultado, pois, pela nova regulamentação seguida por Leitão da Cunha, presidente da banca, os resultados só poderiam ser divulgados em sessão pública da congregação, especialmente convocada para tal. Felizmente, um encontro fortuito com Fróes da Fonseca revelou-me o resultado que me indicava para professor catedrático. Era o princípio de uma nova fase da minha vida.

Alguns dias depois, a congregação se reuniu em sessão pública e confirmou, por unanimidade, o resultado do concurso. Transcorridos os trâmites burocráticos, tomei posse da cátedra. Como já trabalhava na cadeira, foi-me muito fácil assumir o controle do laboratório. Os assistentes que serviam com Francisco Lafayette pediram demissão em conseqüência da nova Constituição, promulgada por Getúlio Vargas, que proibia acumulações de cargos. Eu mesmo solicitei, imediatamente, rescisão do contrato que me ligava ao Instituto Oswaldo Cruz. Contra essa minha decisão opuseram-se vários amigos, entre os quais meu irmão Evandro. A razão principal dessa oposição é que não se poderia jamais pesquisar na universidade e que eu me esterilizaria no simples exercício de atividades didáticas. Meu requerimento de dispensa do Instituto de Manguinhos só foi entregue, por Evandro, na véspera da data 
limite para que os funcionários que acumulavam cargos apresentassem a sua opção. Evandro passou-me vários telegramas para Paris, onde eu me encontrava, só tendo desistido do seu intento de não entregar o meu pedido depois de uma longa conversa telefônica em que eu lhe expus a minha firme decisão de assumir a cadeira na faculdade. Impeliam-me nesse sentido, entre outros, dois motivos principais: a possibilidade de discutir com alunos a matéria ao meu encargo e, principalmente, a intenção de implantar a pesquisa fundamental na universidade, segundo o modelo de atividade que aprendera no Instituto Oswaldo Cruz. Essa implantação fora ensaiada, anteriormente, por Pinheiro Guimarães e Álvaro Ozorio de Almeida, mas sem continuidade.

No dia 23 de novembro de 1937 tomei posse e pronunciei um discurso simples, no qual enunciava as linhas gerais do que seria a minha conduta como titular.

Ao entrar como professor para a Faculdade de Medicina, meu objetivo principal, como já enunciei, era associar o ensino à pesquisa, tornando-a rotineira no lindo e ameno edifício da Praia Vermelha. Trazia para a universidade o que havia aprendido com os mestres de Manguinhos. Além da preparação básica de um convívio extremamente agradável, a noção fundamental de que só pode pesquisar aquele a quem a pesquisa distrai. Ai daquele cientista que não tem o sentido lúdico que o trabalho científico teórico ou experimental traz! Esteriliza-se, este, no meio do caminho e transforma a sua vida seja num desastre intelectual, seja numa amargura sem fim. Penso que aqueles pesquisadores que cedo vão atrás da suposta glória que a administração pode trazer, glória essa que nada mais é do que a sensação falaciosa do poder, só o fazem porque perderam a expressão lúdica que deve acompanhar a pesquisa científica ou, então, por desencontros com a realidade experimental, que thes trouxe o desânimo, impedindo-os de continuar sua trajetória, muitas vezes de brilhante início.

A primeira medida administrativa que tomei foi a de chamar Tito Enéas Leme Lopes para ser meu assistente e chefe de laboratório. A segunda foi a de manter o jovem Lafayette Rodrigues Pereira como participante das atividades a serem desenvolvidas. Tito Enéas Leme Lopes era realmente uma personalidade de exceção. Profundo conhecedor das matérias com que teria que lidar, associava à inteligência rara uma extraordinária capacidade didática $\mathrm{e}$ uma comunicabilidade em que se confundiam sua bonomia e generosidade. 
Ficou ao meu lado até morrer. A sua popularidade com os alunos era total e era a ele que estes levavam as suas dificuldades intelectuais e, até mesmo, problemas de ordem pessoal.

Decidida essa primeira fase de organização da cátedra, achei que, dados os progressos científicos alcançados durante a guerra - muitos dos quais ainda não divulgados em nosso país - , e não tendo eu a preparação para realizar o que desejava, tomei a decisão, de comum acordo com minha mulher, de ir me aperfeiçoar no Velho Mundo. Razões econômicas me levaram a escolher a Europa por ter garantida a hospedagem em Paris na casa de meu cunhado, Afrânio de Mello Franco Filho, então servindo na Embaixada Brasileira e, em Londres, dispúnhamos de um convite do British Council.

Como não havia nenhum sistema prático para obter recursos para viagens de aperfeiçoamento, fui obrigado a vender o automóvel que eu havia comprado, como já disse, com a soma que me fora concedida pelo Prêmio Dona Antonia Chaves Berchon des Essarts, e, como diz Dorival Caymmi em uma de suas canções, "vendemos tudo o que tínhamos": umas poucas ações e alguns objetos de valor. Além disso, Afrânio de Mello Franco presenteou Annah com soma aproximada de dez mil francos. Assim, com o que conseguimos, tomamos o navio inglês da Royal Mail, o S.S. Highland Patriot, acompanhados de Dorinha Campos, amiga da nossa família, e sua governanta, uma professora inglesa, Miss Helen Saville. Nosso destino era Cherbourg, depois de uma parada em Lisboa, o que deu início ao meu encantamento pelas terras de Portugal. De Cherbourg tomamos o trem que nos levou à Gare Saint Lazare, onde nos esperavam Afrânio e Gemina Enquanto nossa bagagem, de pouca monta, era levada diretamente para a rua André Collede-Boeuf, residência de meus cunhados, um táxi nos levou ao rond point dos Campos Elísios, que subimos a pé, lentamente, ouvindo as detalhadas explicações de Afrânio. Não quis ele que eu chegasse a Paris sem imediatamente sentir o amálgama das culturas e civilizações que se misturam ao sentimento gaulês. Fomos até o Arco do Triunfo. De lá, então, tomamos outro táxi e seguimos para a casa onde iríamos morar, muito perto do Sena e fazendo parte do $16^{\text {me }}$ arrondissement. A impressão que me deu Paris, de imediato, foi a de deslumbramento, impressão que se acentuou durante os meses em que ali estive. Chegados à rua André Colle-de-Boeuf, conversamos até altas horas com os nossos anfitriões. 
No dia seguinte acordei cedo, pois pretendia, desde logo, mergulhar na vida científica parisiense. Telefonei para o professor René Wurmser perguntando-lhe se poderia ir vê-lo e apresentar-lhe uma carta de recomensdação, que me fora dada por Miguel Ozorio. Wurmser, que posteriormente veio a se tornar um dos meus maiores amigos e, em muitos aspectos, meu mentor científico, marcou-me uma entrevista para o mesmo dia. Procurei, ainda pelo telefone, o professor Henri Piéron, que havia conhecido no Rio e que era grande amigo dos Ozorio de Almeida. Gentilmente, Piéron marcou um encontro para o dia seguinte.

Naquela mesma manhã saí para andar um pouco pela cidade. Afrânio me ensinara como utilizar o metrô. Estudando o mapa de Paris, resolvi descer na Estação Concorde, atravessar a ponte e percorrer todo o Boulevard Saint Germain, para chegar ao Instituto de Biologia Físico-Química. Situado ao lado do Panthéon, na rua Pierre Curie, ali trabalhava Wurmser. Nessa trajetória, fui respirando Paris e imaginando onde teriam vivido todos os personagens de Em busca do tempo perdido, ou quais seriam as casas que Proust freqüentara. Não podia nem imaginar que, mais tarde, nos anos sessenta, iria residir numa delas. Essas divagações fizeram com que chegasse atrasado, meia hora, ao escritório de René Wurmser, mas o tempo perdido foi tempo ganho, pois pareceu-me que naqueles vinte ou trinta minutos de caminhada eu me integrara à vida parisiense.

$\mathrm{Na}$ esquina do Boulevard Saint Michel havia um restaurante muito simpático: entrei e almocei. Posteriormente, isto se tornou um hábito, pois do Institut de Biologie Physico-Chimique à Rotisserie Perigourdine era um passo. Passei pelo Panthéon, deixando de lado o Jardim do Luxemburgo. Cheguei à rua Pierre Curie e logo me deparei com a entrada do Instituto de Biologia Físico-Química. René Wurmser me esperava e, com gentileza, acedeu à minha participação nos trabalhos do instituto, nos quais o meu grande interesse era o de ter melhor conhecimento dos potenciais de oxirredução. Levou-me ao laboratório onde eu deveria iniciar minhas atividades e no qual trabalhava Sabine Filitti Wurmser, sua mulher, que também amavelmente me recebeu, mostrando minha mesa ao lado da sua. Formou-se entre nós, imediatamente, uma amizade profunda, que avançou pelos anos afora, amizade extremamente valiosa e que deu nova dimensão à minha vida científica. Logo depois, fui conversar com Wurmser e formular o meu programa 
de trabalho. Indiquei-lhe o que eu não sabia e ele estabeleceu o roteiro que eu deveria seguir para dominar o conceito e as técnicas de determinação dos potenciais de oxirredução.

Penso que René Wurmser, homem de profundo conhecimento científico e valioso humanista, me aceitou porque eu era originário de um país de pouco desenvolvimento científico, para o qual deviam convergir o auxílio e os interesses dos países de maior importância política e social. A necessidade de auxiliar o desenvolvimento científico dos países menos evoluídos foi, sem dúvida, uma das marcas de toda a minha ação internacional e o que me levou a aceitar a posição de secretário-geral da Conferência das Nações Unidas sobre Ciência, Tecnologia e Desenvolvimento Social para os Países em Desenvolvimento, realizada em 1963, depois de um ano de preparação em que vivi em Genebra.

Minha estada no Instituto de Biologia Físico-Química não podia ter sido mais atraente. Estava bem aparelhado e com verbas de custeio amplas, patrocinadas principalmente por Edmond de Rothschild, e a congenialidade dos seus pesquisadores e do pessoal técnico, até mesmo do concièrge, deixoume perfeitamente à vontade e como se estivesse em casa, desde o primeiro dia. Além da esplêndida biblioteca, pude participar de reuniões quinzenais, às quais compareciam, com frequiência, as maiores expressões da ciência francesa, como madame Curie ou Langevin ou, então, intelectuais e filósofos de grande valia, como Paul Valéry. Também no instituto assisti às conferências de Meyerhoff, Szent-Gyorgyi e Haldane, tendo tido, assim, oportunidade de conhecer alguns dos cientistas europeus de maior renome no período de entre-guerras.

Estávamos no dia 14 de dezembro de 1937 e marcou-se para o dia 2 de janeiro o início do meu estágio no Instituto de Biologia Físico-Química, depois de uma rápida excursão que faríamos à Itália.

No dia seguinte fui me encontrar com Henri Piéron, de novo com carta de Miguel Ozorio. Piéron tinha estado no Brasil e conhecia muito bem os Ozorio de Almeida. Era ele professor de fisiologia das sensações na Faculdade de Ciências da Universidade de Paris, localizada na Sorbonne. Ao contrário de Wurmser, porém igualmente afável, era um homem de grande estatura, com uma linda cabeça onde se destacavam seus olhos amendoados e a pequena barba sempre muito bem tratada. Combinei com ele de acompanhar 
o seu curso e dividir o meu tempo entre o laboratónio de Wurmser e o laboratónio de Alfred Fessard, no Collège de France.

Alfred Fessard foi dos primeiros fisiologistas a utilizar os amplificadores eletrônicos, os registradores eletromagnéticos e os oscilógrafos de raios catódicos, para estudar as propriedades eletrogênicas dos nervos e dos tecidos. Realizava, além do mais, uma reunião científica semanal, e a primeira a que assisti, na ocasião, tinha como objeto de estudo o peixe-elétrico, Torpedo mamorata. Em companhia de Daniel Auger, os trabalhos eram realizados na Estação de Biologia Marinha de Arcachon, no golfo de Biscaia, mas seu laboratório tinha todo o equipamento para o trabalho com nervos periféricos. Nesse seminário, decidiu-se uma grande parte do meu destino científico, pois ali aprendi a importância que o estudo da bioeletrogênese animal tem para o conhecimento de diversos mecanismos da biologia.

Foi fácil contatar Alfred Fessard, que já conhecia o Brasil por ter vindo passar algumas semanas no convívio dos irmãos Ozorio de Almeida. Aceitou, imediatamente, a idéia de me receber, uma vez por semana, no seu laboratório na Fundação Singer-Polignac, no Collège de France, onde comecei a trabalhar com os instrumentos de registro dos potenciais bioelétricos, seja com oscilógrafos mecânicos, seja, principalmente, com oscilógrafos de raios catódicos. Fessard ensinou-me, também, os princípios fundamentais da ampliação de potenciais elétricos com válvulas eletrônicas. Desse convívio, do qual participou também Denise Albe-Fessard, nasceu uma amizade profunda e uma colaboração que se realizou, com frequiência, nas sucessivas vindas do casal francês aos laboratórios da Praia Vermelha. Também pude seguir o curso de bioeletrogênese que Fessard professava no Collège de France.

Essa primeira permanência naquele país completou-se com uma longa visita ao Instituto Pasteur, acompanhado pelo eminente professor Émile Marchoux, que havia sido aluno de Pasteur, e conhecera rapidamente Oswaldo Cruz. Marchoux, eminente tropicalista, visitara o Brasil no início do século, a convite do governo Rodrigues Alves, para estudar a situação da febre amarela em nossa cidade. Guardara de nosso país uma extraordinária recordação e por duas vezes se referiu à intimidade com que fora recebido, ele e a senhora Marchoux, pela viúva do marechal Deodoro, que os convidara para jantar. Lembrava-se, com emoção, que essa velha dama brasileira mantinha na mesa, admiravelmente bem posta, o lugar que o marechal ocupara. 
Com Marchoux percorri todo o instituto, detendo-me, particularmente, nas reminiscências existentes ainda do relacionamento de Pedro II com essa instituição, que recebera ajuda de nosso imperador. Foi, ainda com ele, que visitei e me ajoelhei junto ao túmulo de Louis Pasteur. A emoção que senti na época, e que hoje ainda sinto, impediu-me, naquele instante, de fazer qualquer comentário com Marchoux. Ainda em sua casa, pois que residia em um apartamento em prédio situado no próprio campus da instituição e mandado construir por Émile Roux, tomei conhecimento de alguns hábitos franceses de então. Nada de aperitivos, pois o vinho que se tomava à mesa não podia ter o seu sabor modificado. O menu era abundante e variado, tomando-se, entre o prato inicial e a came, um pouco de sorvete, o chamado coupe normande. Antes da sobremesa, um prato de ervilhas com pequenas porções de presunto. As frutas eram servidas depois dos doces. O mesmo se deu nas casas em que fui recebido no período entre as duas guerras. Émile Marchoux apresentou-me a algumas figuras centrais do instituto, adjetivando-me sempre com a declaração de ser eu filho do "le grand Chagas". Assim conheci, entre outros, Metchinikov, D’Hérelle e Ramon. Lembro-me, também, de um jovem pasteuriano esguio, de olhos azul-claros, um sorriso um pouco sarcástico, então iniciante na carreira na qual obteve o Prêmio Nobel: André Lwoff.

Acertei com Fessard, como disse anteriormente, que tão logo voltasse da Itália, nos primeiros dias de janeiro, iria procurá-lo.

Nossa viagem à Itália foi rápida. Fomos diretamente a Nápoles. Infelizmente nevava, coisa raríssima. Em Roma, a estada foi esplêndida e compensou totalmente o receio que eu tive de visitar um país fascista. Não sei por que, já que não tinha nenhuma missão oficial, fui procurado, logo ao chegar, por um representante do governo que tentou, à viva força, estabelecer um programa de visitas. Indiquei-lhe que estava em viagem de turismo e que gostaria, apenas, de visitar o professor Nicola Pende. No dia marcado, apareceu-me no hotel, cedo, um representante do Ministério da Educação, que me levou em carro de luxo, precedido de uma bateria de motocicletas, ao serviço do professor Pende. Encontrei-o numa mesa enorme no fundo de um grande salão. Quando me aproximei, ele levantou o braço esquerdo e me saudou à moda de Mussolini. Eu fiquei atônito, sem saber o que dizer. Vendo o meu embaraço, Pende, como para se desculpar, disse: "Qui si saluta alla romana". A conversa, depois, foi amável e ele mostrou interesse 
em levar à Itália um certo número de profissionais brasileiros, e enviar ao Brasil alguns dos seus assistentes, para melhor difusão das suas concepções biotipológicas.

Outra visita que fiz foi a Fermi, que gentilmente nos convidou para jantar. Eu o tinha conhecido por ocasião da viagem que fez ao Brasil, e a sua amabilidade se transformou na maneira cordial com que me levou ao seu laboratório e para jantar em sua casa. Algumas de suas frases relativas ao estabelecimento de um intercâmbio com o Brasil me pareceram vagas e produziram em mim uma certa confusão, que só veio a dissipar-se quando, alguns meses mais tarde, após o recebimento do Prêmio Nobel, Fermi e sua mulher se exilaram nos Estados Unidos, deixando a Itália para sempre. Voltando à França, iniciei meus trabalhos.

A estada em Paris foi extraordinária. Eu trabalhava o dia inteiro, interrompido apenas pelo esplêndido almoço na Perigourdine, seguido sempre de uma caminhada pelo quarteirão. As noites eram, também, plenas. Afrânio e Gemina faziam questão que saíssemos para irmos com eles ao teatro ou a um pequeno café concert. Faziam sucesso, no teatro, peças de Montherlant e outros, mas a grande atração, pela excelência imbatível do espetáculo, era a Comédie Française. Foi nessa ocasião que assisti, pela primeira vez, a Cyrano de Bergerac e, até hoje, me emociono ao lembrar das tiradas românticas ou poéticas, sempre admiravelmente apresentadas. Digo, aliás, que cada vez que assisto ao Cyrano, a emoção se repete.

$\mathrm{Na}$ música popular o grande sucesso era Charles Trenet e, num pequeno teatro da avenida Wagram, começava a ser conhecida a extraordinária Edith Piaf. O hábito de ir aos pequenos café concerts permaneceu em nós. Madeleine Renaud e Jean-Louis Barrault afastavam-se do teatro clássico, possivelmente em busca de maior aproximação com o povo. Em um deles, fui "apresentado" a Jacques Prévert, quando Dany Dauberson cantou Feuilles mortes. Mistingue, Georges Ullmer e outros que vieram a se tornar famosos despontavam na noite parisiense. A saga dos caramujos, mais tarde, completou o nosso apreço pela música popular francesa, que encantava as platéias do Cassino Atlântico, no Rio, por vários artistas gauleses, o principal talvez tendo sido Jean Sablon.

Depois de alguma indecisão, pois eu desconhecia os cientistas com os quais deveria me entreter na Inglaterra, decidimos, Annah e eu, aceitar o convite do British Council. Felizmente o fizemos, pois a nossa estada foi 
extremamente proveitosa. Ficamos alojados num apart-hotel, o Atheneum Court, em Piccadilly. No dia seguinte à nossa chegada, tive o primeiro contato com a ciência inglesa, por intermédio de Sir Frederich Donnan, que nos havia convidado para jantar em sua casa de três andares, muito simpática, no Woburn Square, perto do University College, onde Donnan ainda professava. $\mathrm{Na}$ primeira vez que fui a Londres, logo depois da Segunda Guerra Mundial, fui ver a casa de Donnan. Estava completamente destruída pelo bombardeio dos V2.

O jantar foi extremamente agradável, dele participando Eugene Guggenheim, também do University College. Surpreendi-o quando dei a entender que conhecia seu livro sobre termodinâmica, que me havia sido de grande valia na preparação do concurso. Pelo espanto que demonstrou, verifiquei que Guggenheim mal podia acreditar que um jovem cientista do Terceiro Mundo conhecesse o volume por ele publicado apenas alguns meses antes.

No dia seguinte fui ao Kings College e ali conheci Maurice Wilkins, que me falou, para meu maior interesse, dos avanços recentes da microscopia óptica. Mais tarde, convidei-o para vir ao Brasil e o seu curso sobre "microscopia de reflexão" foi extremamente bem sucedido.

Uma das visitas mais importantes a que já me referi foi ainda no University College, foi a Archibald V. Hill, famoso pela determinação da quantidade de calor que é produzida em um nervo no momento da passagem de um impulso nervoso. Para fazê-lo, obtivera a colaboração de um técnico de laboratório que preparava os pares termoelétricos e o galvanômetro, de grande sensibilidade, utilizado no trabalho. Hill, reconhecendo a contribuição que fora dada por seu técnico, colocou também o seu nome nas publicações. Este é um exemplo que deve estar presente em todos aqueles que se dedicam à pesquisa científica. Hill, muito alto, tinha uma personalidade bastante atraente, marcada, principalmente, pelo seu olhar de um azul-celeste inesquecível e por um sorriso sempre constante em suas conversas. A sua contribuição ao esforço de guerra fez com que Sua Majestade lhe outorgasse uma das mais altas distinções que se concedem a um cidadão britânico: o de Companion of Honour.

Sem dúvida, entretanto, o clímax da minha estada na Inglaterra foi a minha curta viagem a Cambridge e sua famosa universidade. Havia eu 
escrito a Edgard Adrian manifestando o desejo de visitar o Departamento de Fisiologia que ele ali dirigia. A resposta veio rápida, pedindo que eu marcasse a data em que poderia estar em Cambridge a fim de reservar, imediatamente, lugar no hotel. Cheguei a Cambridge, não sei por que, bastante emocionado, emoção acrescida pelo fato de Adrian ter vindo nos esperar na estação. Era ele já avançado na idade, extremamente simpático, cabelos quase totalmente brancos, escorridos, e fumava, de vez em quando, um cachimbo certamente mais velho do que ele. No mesmo dia levou-me ao departamento e me pôs a par do método de trabalho ali adotado. Considerava que uma instituição universitária era essencialmente uma unidade de pesquisa, o que exigia tempo integral para os seus quadros. A expressão "tempo integral" nunca fora por eles utilizada, pois que seria difícil admitir que um pesquisador tivesse outra atividade senão aquela que se passasse num laboratório. Decidiu a universidade que, para combinar ensino e pesquisa, fosse adotada uma fórmula pela qual o pesquisador usaria um tempo variável para ensino - de um a três meses e o restante seria dedicado, exclusivamente, ao trabalho científico. Aprendi logo o que já estava no meu espírito. É que o pesquisador precisa de tempo de lazer e da convivência com os seus colegas e companheiros de trabalho. Por isso mesmo, na Cambridge que visitei, algumas horas eram gastas no almoço e no jantar, não obrigatório, mas a ser comparecido, pelo menos, uma vez por semana.

Adrian convidou-me para, no dia seguinte, jantar no University College, do qual veio a ser Master. A data é fácil de ser lembrada, pois coincide com a iníqua invasão da Áustria pelas tropas de Hitler: 11 de março de 1938. Terminado o jantar, um episódio emocionou a todos os presentes. É que o Master do College, então um eminente matemático, levantou-se e comunicou o acontecimento. Um jovem professor veio à frente da mesa em que estávamos, tentou dizer umas palavras, mas não conseguiu pronunciá-las e caiu em prantos, retirando-se às carreiras. Tratava-se de um brilhante professor austríaco que gozava de um ano sabático em Cambridge. Adrian virou-se para mim, pôs sua mão no meu braço e disse, com a voz embargada: "This means war!" Durante alguns segundos a sala foi tomada por um grande murmúrio que, pouco a pouco, foi esmaecendo. As faces de todos, concentradas, indicavam a preocupação que a notícia causara. Sob um grande silêncio foi servido o Porto pós-prandial e, lentamente, a sala se esvaziou. 
Adrian, que foi feito mais tarde lorde com direitos sucessórios, pela contribuição dada ao esforço de guerra, disse-me, ainda: "É o momento de nós nos unirmos no combate ao nazismo."

Uns dias mais tarde, terminado o descanso que se fazia depois do almoço, Adrian me informou que gostaria que eu o acompanhasse a um seminário sobre estatística; ele compreenderia muito pouco do que o orador queria dizer, por ser o mesmo neozelandês, de prosódia de dificil compreensão pelos britânicos, mas considerava o assunto da maior importância. Assim, fui com ele ao seminário. A sala cheia e o orador, uma pessoa de pequena estatura, rechonchudo, hermético na sua apresentação, era muito amável no entretenimento. Tratava-se de Ronald Fischer, um dos responsáveis pela criação da estatística de pequenas amostras. Geneticista, verificara as dificuldades de utilização da estatística clássica nas suas experimentações genéticas, nas quais predominavam as pequenas amostras. Como Adrian, não entendi quase nada do que Fischer havia exposto, mas os exemplos dados convenceramme da importância dos métodos por ele apresentados e que nada mais eram do que o desenvolvimento das idéias de um pesquisador da indústria produtora de cerveja, Student, que publicara seus artigos com esse pseudônimo, porque só assim podia fazê-lo. Foi daí que começou o meu interesse pela estatística de pequenas amostras. No dia seguinte fui à Livraria Cambridge, de fazer inveja às melhores que tenho visitado. Adquiri os livros de Fischer e outros mais que tratavam do mesmo assunto.

Depois das visitas indispensáveis aos museus londrinos, à Royal Society e à Royal Institution, eu, cheio de entusiasmo pela ciência inglesa e pelos admiráveis espetáculos teatrais, voltei com Annah a Paris, onde ficamos ainda duas semanas para, finalmente, tomar de volta, em Cherbourg, o mesmo navio que nos tinha levado.

No Rio, encontramos alguns amigos nos esperando e o aviso de que haveria uma reunião da congregação a se realizar naquela mesma manhã. Deste modo, fui diretamente do cais do porto para a Praia Vermelha. A sessão era presidida por Raul Leitão da Cunha, e o assunto em pauta, um abaixoassinado dos professores pedindo aumento de vencimentos. Depois de uma rápida discussão foi votada a moção; votei contra aqueles que haviam sido meus professores, e quando me levantei para expressar minha opinião, Leitão da Cunha voltou-se para mim e, solenemente, me disse: “O jovem professor 
está consciente de que é o único voto contra?" Respondi-lhe que sim e a moção foi aprovada antes de encerrada a sessão. Aloysio de Castro disse, então, algumas palavras elogiando a minha atitude. Certamente ela desagradou a muitos dos professores presentes, não só por ser eu muito moço - tinha então vinte e sete anos - como, também, porque lhes pareceu um desafio de um aluno aos velhos mestres que o haviam sempre tratado com muito carinho. Uma das razões do meu voto era que não desejava pedir um favor a quem já era ditador no país e também porque pareceu-me que não podia eu pedir aumento de vencimentos na primeira ocasião em que me manifestava publicamente, tendo escolhido a carreira do magistério e dela conhecendo todas as vantagens e desvantagens, entre as quais, o baixo salánio.

Assumindo a cátedra, duas preocupações tomaram conta de mim. A primeira, a de encontrar elementos para compor o corpo docente que deveria me acompanhar. A segunda, a de encontrar um tema de pesquisa que correspondesse, de um lado, aos meus interesses científicos, focalizados, na ocasião, principalmente nas transformações de energia que se passam no organismo vivo; e, de outro lado, que fosse bastante amplo para que nele se utilizassem as várias técnicas que eu havia apreendido na Europa $\mathrm{e}$ pudesse dar ao laboratório, que eu estava ampliando, um aspecto multidisciplinar.

Como já visto, o primeiro ponto foi solucionado com o convite que fiz a Tito Enéas Leme Lopes para vir trabalhar comigo, e o pedido a Baeta Vianna para que, caso pudesse, me indicasse dois nomes para exercerem funções de assistentes. Este atendeu logo ao meu pedido e me indicou José Moura Gonçalves e João Batista Veiga Salles, que viriam preencher minha deficiência no domínio da bioquímica. Baeta Vianna solicitou-me, também, que recebesse no laboratório Oromar Moreira, que estava se preparando para o concurso de professor catedrático da Faculdade de Medicina de Belo Horizonte. Oromar fez a sua tese sobre oxirreduções no ano e meio que passou conosco, encantando a todos por sua simpatia e bonomia mineira.

Não foi dificil, para mim, contratar os novos colegas, pois os assistentes que tinham servido a Francisco Lafayette Rodrigues Pereira haviam todos pedido demissão devido ao artigo da Constituição de 1938, que proibia a acumulação de cargos. Naquela ocasião, seria impossível viver com a remuneração de assistente de ensino superior. Obtive de Luiz Simões Lopes, 
criador e presidente do Dasp (Departamento Administrativo do Serviço Público), a criação de uma função de técnico especializado. Para essa função, foram nomeados os que eu pretendia tornar assistentes. Dos companheiros de Francisco Lafayette mantive, apenas, o doutor Carlos Feio, já próximo da aposentadoria, e, como monitor, o filho de Francisco Lafayette, como mencionei anteriormente. Enéas Leme Lopes trabalhava, na época, como fiscal das cooperativas de leite em Guaratinguetá. Fora meu colega em todo o curso médico e eu conhecia sua prodigiosa cultura, bem como o seu desejo de ajudar os que o cercavam. Dizem que Tito, ao receber meu convite, embarcou no primeiro trem que partia para o Rio, deixando aberta a casa e nela os seus pertences. Era uma inteligência fora do comum, não só pela profundidade de suas inferências em relação ao que via ou lia, como ainda pela extraordinária mobilidade de sua mente. Havia em Tito, além do mais, um aspecto juvenil que guardou por toda a vida. A sua capacidade didática era muito acima do comum, e foi graças a ele que pude manter, em perfeita continuidade, um curso composto de setenta e dois assuntos distribuídos em quase noventa aulas.

Além disso, organizei para os alunos, que eram geralmente avessos a qualquer fórmula ou raciocínio matemático, um curso sobre estatística de pequenas amostras, realizado por Almir Castro. Seguido pelos outros companheiros de trabalho, a aplicação da estatística de pequenas amostras tornou-se uma rotina, no laboratório. Esse estudo foi completado, mais tarde, pelo conjunto de aulas ministradas por Giorgio Mortara, um exilado italiano que então trabalhava no Serviço de Estatística Nacional.

A colaboração dada à minha atividade por Moura Gonçalves foi inestimável. De um modo geral, era ele particularmente importante por-sua disciplina de trabalho, coragem de atitudes e capacidade expositiva. Coube-lhe, entre muitas outras realizações, a montagem de uma instalação ótica de eletroforese, com a qual realizou trabalhos de significativa importância. Mais tarde, Moura Gonçalves foi convocado para a Faculdade de Medicina de Ribeirão Preto.

Veiga Salles teve, também, papel relevante na formação do grupo inicial do instituto. Convidado para uma instituição científica em São Paulo, sua permanência no Rio foi relativamente curta. Tempos depois, perdeu a vida num desastre automobilístico, lá mesmo, em São Paulo. 
Duas aquisições, da mais alta significação, vieram enriquecer o quadro do instituto: a de Hertha Meyer e a de Aristides Azevedo Pacheco Leão.

Hertha Meyer foi convidada a participar do nosso trabalho porque desejava eu obter, no laboratório, a cultura do Trypanosoma cruzi para vários tipos de pesquisa, entre os quais o da observação dos potenciais elétricos produzidos em corações normais e em corações onde o $T$. cruzi fora cultivado. Já havia eu abordado o assunto, convidando para trabalhar conosco João C. Machado, que instalou a nossa primeira câmara de cultura de tecidos com uma perfeição e metodologia impecáveis. Com a morte de seu irmão, Astrogildo, foi ele ajudar os sobrinhos no estabelecimento da indústria de vacinas para a febre aftosa e o carbúnculo sintomático, até então fabricadas em Manguinhos, mas dele desalojada por imposição do Dasp, que não permitia o recolhimento do produto da venda à tesouraria do instituto. Ficara, assim, desativado o laboratório de cultura de tecidos do Instituto de Biofisica.

O destino me ajudou, então, quando Eudoro Villela, que trabalhava no Instituto Oswaldo Cruz, informou-me da presença de Hertha Meyer como subempregada no laboratório de febre amarela, mantido pela Fundação Rockefeller no Instituto de Manguinhos, onde não podia exercer seus dons naturais de pesquisadora. Hertha Meyer trabalhara com Albert Fischer no Instituto Kaiser Wilhelm, em Berlim, Dahlem. Convidei-a, imediatamente, para trabalhar no Instituto de Biofisica e, graças ao auxilio que Evandro Chagas obteve de Guilherme Guinle, seu laboratório foi instalado em condições bastante satisfatórias. Rapidamente começou a produzir e os primeiros registros elétricos de corações embrionários em cultura de tecidos foram obtidos. O trabalho, apresentado na primeira reunião da SBPC Sociedade Brasileira para o Progresso da Ciência - , realizada em Campinas, foi muito apreciado e abriu as portas para o auxílio que Guilherme Guinle passaria a dar ao nosso instituto, depois de 1940.

Novembro de 1940 marca um hiato na minha vida. É que no dia 8 desse mês, dia a dia, dezesseis anos depois da morte de meu pai, estava eu no meu laboratório quando fui chamado por meu amigo Paulo Lacaz. Perguntou-me ele se eu sabia que um avião da Vasp, em rota para São Paulo, havia caído na enseada de Botafogo. Eu recebi a notícia sem me comover, mas alguns minutos depois, raciocinando, pensei que possivelmente alguma coisa grave havia acontecido, pois era raro que Lacaz me procurasse. Saí apressadamente, 
trêmulo, guiando o carro com dificuldade, sem querer pensar no pior, e fui para casa. Quando ali cheguei já me esperavam alguns amigos. Evandro se encontrava no avião que fora abalroado por um pequeno monomotor usado pela Shell, para propaganda. Eu havia estado com meu irmão na véspera, a seu chamado, no bar do Hotel Central, onde o encontrei na companhia de Valério Konder. Nada me disse da viagem que iria fazer, no dia seguinte, para se despedir da filha Tatiana, pois, duas semanas mais tarde, iria passar mais tempo do que o habitual nos Estados Unidos. Dificil para mim descrever o que senti. Uma das minhas preocupações maiores foi procurar saber se nossa mãe já tinha tido conhecimento da tragédia. Fui com Annah à rua Senador Correia, onde ela morava, e ali a encontrei terrivelmente abalada. Ainda vivia o golpe da morte de meu pai e, agora, tiravam-lhe o primogênito.

Evandro exercia, então, uma função de extraordinária significação para o Brasil. No hospital do Instituto Oswaldo Cruz, hoje Hospital Evandro Chagas, criara o Serviço de Medicina Tropical, que denominou "Serviço de Estudo das Grandes Endemias". Com uma atividade inesgotável, Evandro conseguira, sem recursos do governo, estabelecer mais de dez postos de estudos das doenças que assolam o Brasil, concentrando-se, particularmente, em malária, esquistossomose e doença de Chagas. Viajava por todo o Brasil, tendo recebido um auxílio substancial, em matéria de transporte, da Força Aérea Brasileira. O grande Guilherme Guinle, durante toda a atividade do Serviço de Estudo das Grandes Endemias, atendeu às despesas decorrentes da mesma, que atingiam, no momento da morte de Evandro, quatrocentos contos de réis mensais.

A personalidade de Evandro atraiu muitos jovens de todos os pontos do Brasil ao estudo das doenças tropicais. Era Evandro uma figura fascinante. De pequena estatura, o que marcava seu rosto era a penetração dos seus olhos azuis e a sua facilidade de comunicação. Por onde passava deixava sempre a marca da sua presença, seja no meio médico, seja no social, sendo de assinalar o interesse com que era procurado pelas moças mais bonitas de cada cidade que visitava. Assim foi, praticamente, em todas as capitais de nossos estados. No Pará, a sua ação foi tão importante que, sob a sua influência, criou-se o Instituto de Patologia do Norte, que depois da sua morte passou a denominarse Instituto Evandro Chagas. A sua atividade era realmente incessante. Em uma das fases de sua vida passou meses em Fortaleza, acompanhando a 
campanha contra o mosquito gambiae, que, vindo da África, ameaçava, com grande perigo, invadir todo o território brasileiro. A campanha foi empreendida pela Fundação Rockefeller, mas Evandro foi um dos coadjuvantes, hoje pode-se assim dizer, daquela mais do que benemérita instituição. A convivência social com Evandro era extraordinariamente agradável: sabia apresentar, no momento correto, a anedota apropriada. Discorria, sem nenhum vestígio de egocentrismo, numa voz que nunca se elevava, a não ser em momentos justos. Além disso, não transmitia "disse-que-disse" e nem trazia à conversa o nome daqueles que - e infelizmente foram muitos - o combatiam aberta ou sorrateiramente. Nas suas vivências fora do Rio, principalmente, era um excelente conviva, pois, para arrematar qualquer serão, empunhava um violão e cantava as modinhas mais em voga na época. Cientificamente, tinha grande valor. Disse-me Salomão Adler, por ocasião do Primeiro Congresso sobre Doença de Chagas, que Evandro era, sem dúvida, um grande parasitologista. Afirmou-me, também, que a Leishmania que Evandrodescrevera em doentes com leishmaniose visceral, no Ceará, era realmente uma espécie nova e que cabia a Evandro ter tido a oportunidade, e eu diria a coragem, de assim a apresentar. Evandro conhecia muito bem os vaivéns do método experimental, que aprendera pela experiência e observação, muito mais do que pela leitura de livros e tratados.

A morte de nosso pai marcou-nos, a ambos, de maneira profunda, embora Evandro tivesse, certamente, muito mais relacionamento científico com ele do que eu, em consequiência da diferença de idade: ele era cinco anos mais velho. Nós tínhamos por nosso pai uma extraordinária amizade e admiração, pois víamos nele a imagem do que desejávamos ser.

Evandro era o natural substituto de meu pai por todos os títulos científicos e acadêmicos. Bastaria citar, além dos trabalhos publicados, a sua tese de livredocência sobre $A$ forma cardíaca da doença de Chagas e seu trabalho no Hospital São Francisco de Assis, onde, ainda estudante, dava cursos de radiologia e eletrocardiografia para médicos, cursos esses de larga procura pois, à sua competência e experiência, Evandro juntava uma extraordinária capacidade didática. Além do mais, era um clínico notável e, em várias ocasiões, me admirei de seus diagnósticos, feitos à cabeceira do doente, muitas vezes contestando os chefes de enfermaria. Fez-se, entretanto, para substituir meu pai, uma conspiração que o impedisse de alcançar a cátedra. Um exemplo 
desse ardil pode ser observado no seguinte fato: dirigi-me ao diretor da Faculdade de Medicina para perguntar-lhe, cordialmente, a razão pela qual não se havia dado a Evandro, depois da morte de meu pai, a chefia interina da cátedra, já que o curso equiparado, que ministrava às tardes, tinha tanta freqüência - e, na maioria, assistido pelos mesmos alunos - quanto aquele dado por meu pai, pelas manhãs. A resposta que obtive foi que Evandro tinha levado uma vida de boêmio e que ninguém poderia garantir o seu comportamento como professor, informação essa que lhe fora dada por um dos maiores amigos de meu pai. Formou-se, assim, uma banca relativamente medíocre, que deu a cátedra a um respeitável professor de grande conceito moral e pessoal, mas de pouco comércio com a ciência e com as doenças tropicais. Pôde-se perceber a diferença entre os dois candidatos pelas provas do concurso. As de Evandro foram de uma superioridade esmagadora, juízo que não é só meu, mas de todo mundo que lhes assistiu. Pequenos fatos mostram, ainda, a flagrante parcialidade, tão comum nos concursos aos quais vim a assistir na minha faculdade. Um dos examinadores, ao ser interrogado por um amigo por qual razão tinha dado, na prova oral, menor nota a Evandro do que ao candidato vencedor, respondeu com a simplicidade de um beócio: "É que para o Evandro foi sorteado um caso de doença de Chagas, que ele tinha obrigação de saber muito bem." $O$ resultado nada mais fez do que dar mão forte à cabala que se organizara, não só contra Evandro, mas, também, a favor do seu único adversário.

Citarei, dentre os jovens que se inspiraram em Evandro no estudo das doenças tropicais, por exemplo, Wladimir Lobato Paraense, que se tornaria, dentro de pouco tempo, grande malacologista, dando contribuição significativa ao estudo da esquistossomose; Leonidas e Maria Deane; e, ainda, Felipe Nery Guimarães, que viria a ser, mais tarde, diretor do Instituto Oswaldo Cruz. Antônio Couceiro, do Recife, foi um dos chamados por Evandro, mas chegou ao Rio depois da morte de meu irmão. Passou então a fazer parte do grupo de pesquisadores que se abrigaram junto ao Instituto de Biofisica da UFRJ.

A morte de Evandro trouxe modificações ao Serviço de Estudo das Grandes Endemias. Foi necessário, primeiro, encontrar o substituto de meu irmão. Seus companheiros consideraram que eu seria o candidato natural. As circunstâncias me levaram a aceitar o cargo e, assim, vi-me trabalhando das 
oito ao meio-dia, no Serviço de Estudo das Grandes Endemias, para garantir a sua atividade e, a partir das quatorze horas, na Praia Vermelha, no instituto que eu havia criado e que já tomara um certo desenvolvimento.

Dois objetivos se antepunham ao meu trabalho. Um deles era a necessidade de manter, financeiramente, o Instituto de Biofisica. $O$ outto, o de incluir no Serviço Público Federal, vale dizer, no Instituto Oswaldo Cruz, os que assim o desejassem. Conversando com Guilherme Guinle, ficou assentado que ele continuaria a manter o serviço até o momento em que o mesmo fosse absorvido pelo governo federal. Para integrar os rapazes que ali trabalhavam fui me entender com Luiz Simões Lopes. A receptividade que teve o meu pedido foi a maior possível, o que era de se esperar de um homem com a visão e o interesse pelo serviço público, ao qual se sacrificara, inteiramente, Simões Lopes.

Outro aspecto na vida de Evandro é dado pela sua extraordinária capacidade de enfrentar problemas, por mais complexos que fossem. Assim é que a criação do Serviço de Estudo das Grandes Endemias encontrou natural antagonismo por parte de muitos pesquisadores do Instituto Oswaldo Cruz. Era novidade e, como tal, merecia uma análise, de cabo a rabo, para ser aceita. Além do mais, trazia ela para a casa elementos desconhecidos e, em geral, bem jovens, desfazendo a pretensão de muitos que já ali trabalhavam. Ainda mais, era um desafio científico, pois que os assuntos a serem abordados eram todos do interesse de vários laboratórios. Evandro conseguiu vencer todos os obstáculos. Cardoso Fontes, então diretor do Instituto de Manguinhos, dera a Evandro apoio a uma iniciativa que não era do agrado de todos os funcionários do Instituto Oswaldo Cruz, e Simões Lopes criara as condições para enquadrar os companheiros de Evandro no serviço público. Ao fim de quatro meses após a morte de meu irmão, pude ir a Guilherme Guinle para lhe dizer que as suas responsabilidades no projeto que tanto the devia estavam terminadas. Naquele momento, Guilherme Guinle disse-me: "Se agora minhas responsabilidades com seu irmão ficam suspensas, quero me dedicar, do mesmo modo, ao seu trabalho no Instituto de Biofisica." Foi-me dificil saber como agradecer-lhe. Creio que a minha gratidão se manifestou através do meu olhar. O oferecimento de Guilherme Guinle era a garantia de que eu poderia pesquisar na universidade. 


\section{V \\ Instituto de Biofisica Carlos Chagas Filho}

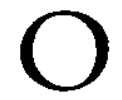

Instituto de Biofisica só passou a existir oficialmente com o decretolei $n^{\circ} 8.393$, de 17 de dezembro de 1945 . Sua criação deu-se de um modo todo especial: tendo sido Raul Leitão da Cunha nomeado ministro da Educação e Saúde, chamou-me ao seu gabinete para me perguntar o que eu achava que deveria ser feito por nossa universidade. Respondi-lhe que a primeira coisa seria o estabelecimento do tempo integral, particularmente para as cátedras fundamentais. A seguir, propus a ele que se organizassem institutos de ensino e pesquisa nas várias disciplinas básicas. Era este um assunto que eu havia discutido com professores da Universidade de São Paulo, sendo que, na ocasião, fui uma minoria esmagada. Leitão da Cunha perguntou-me quais os institutos que deviam ser criados imediatamente. Física, química e matemática seriam os primeiros, com a responsabilidade de neles se ministrar o ensino dessas matérias para todos os cursos da universidade. Perguntoume, ainda, o ministro, se eu poderia me ocupar da criação do Instituto de Física. Respondi-lhe, de imediato, que não teria eu a competência necessária, mas que havia na universidade um professor capaz de fazê-lo: Joaquim da Costa Ribeiro. Leitão da Cunha tomou nota e, virando-se para mim, perguntou: "E para você, o que devo fazer?" Disse-lhe sem pestanejar: "Criar o Instituto de Biofísica, que terá a função de implantar a pesquisa na Faculdade de Medicina e trazer para o nosso meio os métodos fisicos que despontaram nos centros maiores depois da Segunda Guerra Mundial, e o desenvolvimento dos métodos eletrônicos." Leitão da Cunha aquiesceu imediatamente, como 
também aquiesceu à minha proposta de incluir, na universidade, o Instituto Oswaldo Cruz e o Museu Nacional. O ministro pediu-me que obtivesse o apoio dos membros dessas duas instituições ao que eu propunha. Foi assim que pude começar a trabalhar com grande independência administrativa como diretor do Instituto de Biofisica era membro do Conselho Universitário - e recursos necessários ao planejamento que havia feito.

O desafio era mais do que tentador, pois ia realizar o sonho de ver a pesquisa básica ser exercitada na Faculdade de Medicina. Dois problemas, entretanto, surgiram para serem resolvidos imediatamente. $O$ primeiro, o do potencial humano, então inexistente. O segundo, o do equipamento do laboratório com as novas técnicas físicas e bioquímicas que havia visto e aprendido, algumas delas, na minha viagem à Europa. Em seguida, havia o problema da escolha de um tema de pesquisa que reunisse um certo número de características e, principalmente, a de ser um modelo encontrado, se possível, somente no Brasil. Isto para pôr em ação a minha idéia de que, em países como o nosso estamos no início da década de quarenta - , a pesquisa chamada "nacional" deve tratar de um assunto característico do país, ainda que usando a melhor colaboração técnica e intelectual do estrangeiro.

Quanto à formação de pessoal, era-me fácil compreender que, com a guerra, o avanço técnico e científico dos países do Primeiro Mundo havia aumentado consideravelmente. Quantos foram os instrumentos que, na minha curta viagem à Europa eu só havia visto em livros e revistas! Para a constituição do núcleo de jovens pesquisadores que se juntaram a mim e que, realmente, permitiram a formação do Instituto de Biofisica, procurei, em nosso país, encontrar alguns dos elementos de que necessitava. Tive então a surpresa agradável de ver o instituto ser procurado por inúmeros estudantes de medicina e de outras disciplinas, os quais se juntaram ao pequeno núcleo formado por Tito Leme Lopes, Moura Gonçalves, José Veiga Salles e Oromar Moreira. Todos os companheiros do primeiro grupo tiveram projeção na comunidade científica e muitos deles vieram a ser titulares, seja na nossa universidade, que ainda se denominava Universidade do Brasil, seja em outras. Creio que a atração pelo instituto nascia do fato de estar ele muito perto do centro da cidade, único campo em que podia competir com o Instituto Oswaldo Cruz. Creio, ainda, que o nome de meu pai exerceu influência nessa procura e, por fim, a minha 
relativa mocidade, talvez, o que me permitiu uma grande convivência com alunos pouco mais moços do que eu.

Preocupei-me, também, com o ensino ministrado em aulas teóricas três vezes por semana - e aulas práticas dadas para pequenas turmas. Ao mesmo tempo, interessei-me pela modificação dos métodos de ensino, com a possível utilização dos novos métodos de comunicação. Estava eu influenciado pelas palestras às quais assistira de um educador francês, L. Dieuzaide, que realizara, na França, experiências do mais alto interesse. Para tanto, chamei de Brasília o livre-docente de biofísica Luiz Carlos Lobo. Assim foi feito o projeto do Núcleo de Tecnologia Educacional para a Saúde (Nutes) que, localizado inicialmente numa das salas do nosso instituto, na Praia Vermelha, foi posteriormente instalado no Edificio do Centro de Ciências Biomédicas, no Fundão. $O$ Nutes deu origem a um projeto patrocinado pela Organização Pan-Americana de Saúde, destinado a levar aos países latino-americanos, por meio do Centro Latino-Americano de Tecnologia, Educação e Saúde (Clates), as vantagens metodológicas obtidas aqui no Rio.

Quanto ao tema de pesquisa, o tempo de escolha foi mais longo. Sabia que o grupo de Aristides Leão iria trazer para o laboratório o estudo do sistema nervoso central, capítulo assim resolvido. Entre modelos abundantes em nosso país, cogitei do bicho preguiça e dos vaga-lumes, extremamente abundantes em alguns pontos do país, porém já utilizados em laboratórios de projeção, como os de Newton Harvey, da Universidade de Princeton. A preguiça é de dificil manutenção em cativeiro e foi preterida pelo peixeelétrico do Amazonas, o chamado poraquê, para o estudo do qual o Jardim Zoológico de Nova York havia organizado recente expedição ao Amazonas. Essa expedição fora subsidiada por um milionário americano, B. Baruch, que tinha sido informado de que, do órgão elétrico do poraquê, poder-seiam tirar substâncias de ação contra a impotência sexual. $O$ ministro da Agricultura de então, Fernando Costa, por coincidência ou por informação cuja origem desconheço, chamou-me, um dia, ao seu gabinete e prometeume recursos bastante amplos para que eu estudasse o vaga-lume. Tal oferecimento, de grande valia, mostrava, sem dúvida, o alto interesse de Fernando Costa pela exploração de riquezas brasileiras. Levei algum tempo estudando a bibliografia existente sobre o assunto e cheguei à conclusão de que, provavelmente, a escolha seria decepcionante, face ao que se estava 
fazendo em países mais bem apetrechados. Ainda mais que, na época, a importação do moderno equipamento produzido durante a guerra era de dificil acesso.

O poraquê parecia-me ideal para o estudo das transformações energéticas em seres vivos. Tendo em vista o que observara em Paris, nos seminários de Auger e Fessard sobre o Torpedo, uma oferta decidiu o que deveria fazer. Veio ela do empresário Joaquim Rôla, que, na ante-sala do Cassino da Urca, de sua propriedade, mantinha um aquário repleto de poraquês, com a finalidade de mostrar ao público, muitas vezes embasbacado, a facilidade na produção de eletricidade por animais. Prometeu-me fornecer aqueles de que eu necessitava e, mais ainda, apresentou-me ao senhor Bernardo Maiman, que, ictiologista amador, trazia do vale amazônico peixes que serviam como atrações circenses. Com essa ajuda, via eu o caminho que desejava seguir. Electrophorus electricus - condutor de eletricidade, como o apelidou Lineu - era um espécimen biológico que me permitiria estudar, ao lado da transformação bioquímica em energia elétrica, aspectos extremamente interessantes da bioquímica, bioestrutura e biologia celular, em estudo comparativo com outros animais, principalmente aquáticos. A multiplicidade de possibilidades de linhas de pesquisa que o animal oferece traz, ainda, a oportunidade de uma investigação multidisciplinar, que é o caminho mais certo para o desenvolvimento científico, infelizmente perturbado, hoje, pela especialização linear.

O outro campo de atividade com que tive que me defrontar foi o da formação de pessoal. Dois caminhos tinha eu a seguir: o primeiro, o da formação em nossos próprios laboratórios, daqueles que o desejassem. $\mathrm{O}$ segundo, o envio ao estrangeiro do maior número possível de moços e moças cuja experiência é hoje denominada, com freqüência, de "iniciação científica". Infelizmente, na ocasião não haviam fontes financeiras em nosso país para esses estágios no estrangeiro. Tive, então, a ajuda da Fundação Rockefeller, que só se alargou, mais tarde, com o Conselho Britânico, também muito restrito em suas possibilidades, e, finalmente, o Serviço Cultural do Ministério das Relações Exteriores da França, aquele que mais socorreu o instituto, principalmente quando, em Paris, foi assumido por Louis Joxe e madame Gabrielle Mineur, que veio a ser adida cultural da França no Brasil, e que aqui exerceu uma incomparável atividade de cooperação entre os nossos países. 
Uma terceira etapa consistiu em fazer vir, para estagiar em nosso instituto, o maior número de cientistas, de bom ou melhor calibre, dos países desenvolvidos. Esta foi, aliás - e não o esqueçamos - a política de Oswaldo Cruz, trazendo para trabalhar em Manguinhos von Prowazeck, Max Hartmann, G. Giemsa e Hermann Düerck. Seguindo essa orientação, o instituto recebeu mais de duzentos visitantes, na sua quase totalidade cientistas de notório saber e grande congenialidade.

Dos primeiros visitantes a estagiar conosco por mais tempo cito René Wurmser e sua mulher, Sabine Filitti Wurmser, os quais, deslocados de Paris para Lyon pela ação inconseqüente e maldosa da Gestapo, aqui vieram passar um pouco mais de dois anos, até que o governo do general De Gaulle mandou buscá-los para que auxiliassem as tropas independentes francesas no seu esforço de guerra. A colaboração dada pelo casal Wurmser ao nosso desenvolvimento é incalculável. Partilharam conosco todos os problemas e nos ajudaram a vencer as vicissitudes.

Ao chamar cientistas estrangeiros para estagiarem no Instituto de Biofísica, nunca me preocupei com o tempo que aqui deveriam ficar, mas sempre com a qualidade daquilo que vinha escrito nos contratos. Certamente, a de Wurmser foi a mais longa permanência, e a mais curta foi a de Fritz Lipmann. Este passou oito dias nos laboratónios da Praia Vermelha, mas foi o suficiente para configurar, a todos os que ali foram ter nas longas aulas-conferências que Lipmann pronunciou, a significação exata dos ligamentos fosfóricos ricos em energia e do modo de transmissão da mesma de molécula para molécula. Parece-me que ficou satisfeito com os contatos feitos e com o nivel de conhecimento encontrado, dizendo-me mesmo que receberia em seus laboratórios, com a maior satisfação, um dos meus mais brilhantes companheiros de trabalho, Maury Miranda.

Dentre as iniciativas tomadas nessa ocasião, assinalo a criação de um laboratório de radiobiologia e um de citoquímica. A necessidade de um laboratório de radiobiologia era iminente pelo fato de se dar um fundamento científico mais exato à radioterapia, e pelo desenvolvimento que as pesquisas com energia nuclear haviam tomado. Estamos, ainda, na época do assombro e horror causados pelas explosões de Hiroshima e Nagasaki, e do atraso nos conhecimentos básicos que pudessem se contrapor, por menor que fosse o efeito, à terrível destruição produzida pelas armas nucleares. A primeira 
medida tomada nesse sentido foi o convite feito a Raymond Latarjet, um jovem e já ilustre pesquisador francês, para vir ao Brasil. Latarjet aqui esteve durante três meses e, terminado seu estágio, convidou, para minha alegria, um dos jovens que se ensaiavam na ciência, Luiz Renato Caldas, a estagiar no Instituto Curie, de Paris. Luiz Renato Caldas cursava, na ocasião, o segundo ano médico, mas teve coragem bastante para aceitar o desafio e interromper, por quase um ano e meio, o seu curso na Praia Vermelha. A estada de Caldas em Paris deu-se em momento extremamente oportuno, pois abria-se à ciência moderna a era da biologia molecular e os pesquisadores do Instituto Pasteur, Jacques Monod, François Jacob e André Lwoff, trabalhavam em íntima colaboração com a equipe do Instituto Curie. Mais tarde, para acompanhar o desenvolvimento da chamada biologia moderna criou-se, no Instituto de Biofisica, uma seção de radiobiologia, que lhe foi entregue. Desde esse momento, estudos sobre o bacteriófago tornaram-se rotina na instituição. Este setor ampliou-se com a criação de um laboratório de fotobiologia, onde foram estudados os efeitos terapêuticos do ultravioleta no herpes e a ação bacteriotóxica do corante que tinge as águas do rio Negro.

Luiz Renato Caldas deu um grande impulso à radiobiologia em nosso país. Moço, não poupou suas energias, dividindo-as, sabiamente, entre o Hospital dos Servidores, onde ingressou por concurso, em primeiro lugar, e o Instituto de Biofisica, no qual passava a maior parte do tempo. Pelas condições especiais da disciplina, Caldas foi um dos poucos pesquisadores da Biofísica a dividir suas atividades em duas etapas: a da pesquisa fundamental, que exercia no Instituto de Biofisica, e a da aplicação dos conhecimentos obtidos, aqui e além-mar, na radioterapia do câncer.

A regra do tempo integral ou exclusivo é essencial para o desenvolvimento científico de uma instituição de pesquisa. Houve instituições dessa ordem, no Brasil, que tiveram as maiores dificuldades no seu próprio desenvolvimento ou, então, tiveram o seu trabalho esmorecido porque não conseguiram as condições necessárias para implantar, nos seus quadros, o tempo integral, conquista da ciência que de nenhum modo pode ser menosprezada. Essa dificuldade se acentuou ainda mais quando, à medida que o país se desenvolveu, instituições públicas ou particulares vieram procurar, nos quadros científicos, os elementos necessários à sua evolução, e tornou-se gravíssima quando a nova Constituição, promulgada em 1938, proibiu, como já dito, de 
maneira a mais vigorosa, qualquer tipo de acumulação de cargos. Tão saudável disposição só poderia ser realizada se os salários dos pesquisadores tivessem sido elevados, de forma que não lhes fizesse falta a fração que o dispositivo de desacumulação retirava dos seus estipêndios mensais. Essa situação não alcançou o Instituto de Biofísica, apenas começante, mas descontrolou algumas das melhores instituições de pesquisa e atingiu, profundamente, as universidades, cujo corpo docente possuía, em grande parte, professores que acumulavam outros cargos. Este é um exemplo de uma medida que, sendo indispensável, teve um efeito que custou a ser saneado, e só o foi quando o Conselho Nacional de Pesquisas, graças à ação de Simões Lopes e do almirante Álvaro Alberto, criou bolsas complementares de tempo integral e novos dispositivos legais vieram tornar possível alguns casos de duplo emprego.

Durante esse tempo, o Instituto de Biofisica foi crescendo, principalmente no setor de pessoal. Muitos dos jovens que foram procurá-lo resolveram permanecer em seus laboratórios. Verifiquei, então, como tinha sido proficua a transformação do laboratório em instituto, pois, para vários deles, pude encontrar situações que, embora não fossem ideais, eram equiparáveis às bolsas do Conselho Nacional de Pesquisas, sem dúvida um dos alicerces da edificação do instituto e um dos elementos-chave do desenvolvimento da ciência brasileira, a partir dos meados do século XX.

Quando senti que poderia me afastar do instituto por algum tempo, resolvi fazer uma segunda viagem de aperfeiçoamento ao estrangeiro. Essa viagem foi de extraordinánia significação para mim. Ampliei na França, na Itália e na Inglaterra o meu universo cultural e apreendi como evoluiu a ciência moderna, assim chamada aquela que se desenvolveu, sobretudo durante e após a Segunda Guerra Mundial. Sem dúvida, essa viagem, embora curta, pois fiquei apenas cinco meses na Europa, deu-me uma nova dimensão da significação da ciência e da tecnologia no mundo moderno e um conceito de como elas devem se desenvolver.

Foi o que tentei fazer no Instituto de Biofisica. Criei o instituto movido por razões que cada vez me parecem mais claras. Para poder pesquisar na universidade, precisava eu de certa liberdade administrativa, o que a nova situação institucional me dava tirando parte do peso burocrático que existe em qualquer atividade ligada ao Estado. Com o instituto, podia me mover muito mais facilmente dentro da universidade. Além do mais, e possivelmente 
de maneira primordial, teria eu independência para dirigir-me às fontes doadoras de recursos, tais como o Congresso Nacional, as fundações estrangeiras, ministérios e personalidades de visão. A criação do instituto causou, em muitos círculos, apreensão, e algumas tentativas de cópia da minha iniciativa foram ensaiadas. $\mathrm{Na}$ verdade, não era ela, propriamente, uma inovação, pois já existia na universidade um Instituto de Radioterapia e, ao mesmo tempo, uma situação especial dada à clínica obstétrica, na maternidadeescola. Achei melhor não entrar em polêmica e a única pretensão que se realizou foi a de que o diretor do instituto pertenceria ao Conselho Universitário.

Foi essa uma época em que realizei, auxiliado por vários dos meus amigos, muitas das minhas idéias sobre pesquisa, universidade e sociedade. $\mathrm{Na}$ universidade, por exemplo, como já mencionado, chamei a atenção de Leitão da Cunha, então ministro da Educação, para a criação de institutos básicos de ciência, que foram implantados. Obtive, também, a inclusão do Museu Nacional na nova instituição, criando-se a categoria de Instituição Nacional. Infelizmente, tal iniciativa gorou em relação ao Instituto Oswaldo Cruz. Embora vencido, não fiquei convicto. $O$ episódio pode ser relatado, pois é curioso. Para incluir o Instituto de Manguinhos na universidade, o ministro Leitão da Cunha solicitou-me que obtivesse um documento no qual a maioria dos pesquisadores do Instituto Oswaldo Cruz se mostrasse de acordo com a idéia. Isto foi executado sem dificuldade e a transferência foi feita e, logo em seguida, desfeita, em face de um novo abaixo-assinado firmado, na sua grande maioria, pelos mesmos signatários do primeiro, pedindo que o ato fosse revogado. O que aconteceu. Consegui, ainda, um regulamento para o Instituto Oswaldo Cruz, com a criação de departamentos especializados. Não que eu quisesse comandar o Instituto de Manguinhos, mesmo porque já recusara, por três vezes, um convite presidencial para presidi-lo. É que a minha formação dentro do espírito do Instituto de Manguinhos a ele me ligou, definitivamente, e de forma inapagável. Chego algumas vezes a crer que, se o meu pensamento e a minha emoção se fixam no desenvolvimento do Instituto de Biofisica, uma grande parte do meu coração permanece do outro lado da avenida Brasil, no Instituto Oswaldo Cruz.

$\mathrm{Na}$ criação do Instituto de Biofisica não houve, da minha parte, o menor desejo de engrandecimento, ou de me sobrepor à atividade de meus outros 
colegas universitários. Conduziu-me, nessa operação, o desejo de implantar na universidade, marcada pelo interesse intelectual dos jovens e das jovens que a procuravam, as novas técnicas que havia visto na Europa e que ainda não eram correntes no Brasil, muitas delas podendo trazer, até mesmo, modificações conceituais nos modelos institucionais que as caracterizavam.

Não foi dificil a formação de pessoal necessário. A verdade é que, como já disse, começaram a aparecer rapidamente candidatos a um estágio nos laboratórios do instituto. De outra parte, eu mesmo quando encontrava provas de vestibular de excepcional qualidade, convidava o aluno a procurar-me e comigo discutir a validade de um aprendizado científico e, até mesmo, de uma carreira científica. Os que aceitavam o meu oferecimento recebiam uma pequena ajuda mensal, sob a égide de monitoria. $\mathrm{O}$ aluno aceito depois da entrevista, quase sempre feita comigo, era encaminhado a um dos pesquisadores do instituto, que assumia, então, a tarefa de ser orientador. Além do mais, o instituto ministrava um curso especial para os monitores no qual aprendiam as técnicas comuns no laboratório de pesquisa, começando pela lavagem de vidros. Antes do término, tinham eles obrigação de fazer o cálculo estatístico das medidas realizadas. Aos que se destacavam nesse estágio, a ida ao estrangeiro, para o aperfeiçoamento, era-lhes facilitada.

Se não houve muita dificuldade no encontro de candidatos às monitorias $\mathrm{e}$ à construção da base científica de sua formação, a escolha de um modelo biológico recaiu, como já disse, no Electrophonus electricus (L.), pelo número de mecanismos biológicos diversos nele encontrados. $\mathrm{E}$ ainda, porque a missão de Coats, Cox e Nachmanson, pesquisadores norte-americanos do Jardim Zoológico de Nova York e da Universidade de Columbia, subvencionados por uma fonte privada para estudar o E. electricus na Bacia Amazônica, havia publicado um longo artigo sobre os aspectos macroscópicos da atividade do poraquê. A leitura desse artigo serviria de guia para a comparação com os resultados que obtivéssemos. $\mathrm{Na}$ verdade, assim foi. Não conseguíamos encontrar a velocidade de transmissão nervosa que aqueles autores citavam e que estavam em profundo desacordo com aquela que era considerada normal pelos neurobiologistas da época. Aqueles pesquisadores partiram do pressuposto de que a descarga elétrica iniciava-se no limite anterior do órgão principal, quando, na realidade, ela se deflagra no terço médio, propagando-se o fenômeno excitatório para a frente, ou seja, para a cabeça, e para a extremidade posterior. 
Na primeira vez que fiz uma exposição sobre os trabalhos realizados no instituto, a assistência, composta por pesquisadores do Departamento de Fisiologia do University College, em Londres, local da minha preleção, deu sinais evidentes de regozijo por eu ter encontrado um engano na referida publicação. Por isso mesmo, quase todas as questões que me foram formuladas ao término da minha exposição referiam-se a essa omissão dos articulistas.

O peixe-elétrico, portanto, tornou-se uma das três linhas-mestras da pesquisa do Instituto de Biofisica. Uma outra foi o estudo da chamada depressão alastrante, ou Leão's spreading depression, como é conhecida mundialmente. Esse fenômeno foi descoberto por Aristides Azevedo Pacheco Leão, que ingressou no quadro do instituto logo depois de sua chegada dos Estados Unidos, onde trabalhou num dos mais famosos centros de fisiologia da América do Norte: a Universidade de Harvard. Aristides Leão, sem dúvida um dos maiores cientistas que conheci, era extremamente simples e culto, grande estimulador da pesquisa entre os jovens e excepcional professor de fisiologia geral e comparada, sobre a qual discorria com facilidade e profundidade, $o$ que só o conhecimento e a reflexão podem trazer. Tinha, além do conhecimento real do seu campo de trabalho - a eletrobiologia - , uma esplêndida erudição e vasta capacidade criativa em todo o domínio da biologia básica e da ecologia. Integrado ao instituto, Leão rapidamente organizou o seu laboratório, cercado de seus discípulos, entre eles Hiss Martins Ferreira, Eduardo Oswaldo Cruz, Romualdo José do Carmo, Carlos Eduardo Rocha Miranda e Gustavo de Oliveira Castro, os quais rapidamente transformaramse em chefes de escola. Desenvolveram-se trabalhos sobre bioeletrogênese no músculo cardíaco embrionário. Esta linha, conseqüência do interesse em estudar a eletrogênese cardíaca, trouxe ao Brasil, por seis meses, o professor Brian Hoffman, da Universidade do Estado de Nova York.

Muitos foram os pesquisadores estrangeiros que estagiaram nos laboratórios de eletrofisiologia do instituto. Destaco a presença de Jan Bures, da República Tcheca; Wade Marshall, do National Institutes of Health (NIH), EUA; Tsuneo Tomita, da St. Marianna University, Japão; e Charles Nicholson, da Universidade de Nova York, EUA. Bures, cujo laboratório tem estudado a depressão alastrante durante várias décadas e que publicou um importante livro de revisão sobre mecanismos e aplicação do "fenômeno de Leão", visitou o Brasil, patrocinado pela Unesco. 
A messe de atividades científicas do grupo permitiu a realização de um significativo simpósio internacional, organizado por Romualdo José do Carmo, que resultou na publicação de um volume, Spreading Depression, pela SpringerVerlag, em 1992. Aristides, falecido em dezembro de 1993, deixou um grande número de discípulos espalhados no Brasil e além-mar, como testemunha Jan Bures, representando a Academia de Ciências da República Tcheca, na homenagem póstuma que a Academia Brasileira de Ciências lhe dedicou, em abril de 94:

I feel to be an old alumnus of Leão's invisible college, of the informal scientific community the members of which are scattered all over the world, but are nevertheless unified by the mysterious spell of a challenging problem, by the strong bonds formed in the joint pursuit of knowledge.

Isto é uma indicação de seu valor e do seu reconhecimento como cientista pela comunidade científica internacional. Aristides era um artífice experimental de qualidade insuperável. Suas experiências, simples e facilmente reproduzíveis, apresentaram resultados de extraordinária significação para o conhecimento do funcionamento do cérebro. Não só descobriu o fenômeno da depressão alastrante como, já aqui no Brasil, descreveu todas as suas principais características. Consiste a depressão alastrante de um apagamento reversível da atividade elétrica espontânea do córtex, causada por estimulação local, que invade, lenta e sucessivamente, as regiões circunjacentes - donde o nome depressão alastrante - e pode passar de um hemisfério para o outro. Provavelmente está ligada aos mecanismos íntimos de certos fenômenos patológicos que ocorrem no cérebro, como, por exemplo, a epilepsia jacksoniana e a enxaqueca. Alterações físico-químicas, que ocorrem no momento de sua produção, são estudadas, cuidadosamente, não só aqui no Brasil, mas em vários laboratórios espalhados pelo mundo, e podem trazer contribuição de grande valia para o conhecimento dos fenômenos psicossomáticos. Aristides Azevedo Pacheco Leão teve decisiva influência na projeção internacional do Instituto de Biofísica como instituição de excelência.

A terceira linha a que quero me referir é a do cultivo do tripanossoma em cultura de tecidos. Foi graças ao estímulo e à subvenção material que Evandro Chagas me deu que resolvi, ao assumir a cátedra, criar um grupo em torno desse assunto, já que era de interesse do Serviço de Estudo das Grandes Endemias. Hertha Meyer trabalhou no instituto como líder do 
laboratório de cultura de tecidos até o seu desaparecimento, em 1990, aos oitenta e dois anos, sem descanso ou férias prolongadas. Tornou-se uma pesquisadora de renome internacional e o seu trabalho permitiu à UFRJ conceder-lhe o título de Doutor Honoris Causa, primeiro título honorífico do seu curriculum vitae. A assiduidade de Hertha Meyer ao trabalho, no qual punha toda a sua dedicação e inteligência, foi certamente um grande estímulo a todos os jovens que passaram a estudar e trabalhar no Instituto de Biofisica.

Outro fator decisivo no desenvolvimento inicial do instituto foi o da presença, em seus laboratórios, do casal René Wurmser. Quando da minha viagem à Europa, logo depois de empossado na cátedra, conheci René Wurmser, como já relatei, no Instituto de Biologia Físico-Química, em Paris. Com ele trabalhei durante três meses. Wurmser, um varão de excepcionais qualidades, tinha uma personalidade tão forte que transparecia através de sua simplicidade. Havia feito uma carreira brilhante. Mobilizado durante a Primeira Guerra Mundial, fez parte do Corpo Expedicionário Francês que foi combater nos Dardanelos. Na volta à França, foi chamado a trabalhar na Sorbonne para, logo depois, fazer parte da extraordinária missão francesa que foi criar a Universidade de Estrasburgo, composta de um grupo de excepcional capacidade científica e qualidade humana. O governo francês enviou esse grupo à Alsácia, já agora desocupada, para dar maior prestígio à presença francesa nas províncias que os alemães, pelo Tratado de Versalhes, foram obrigados a devolver à França. Já em Estrasburgo, Wurmser começou seus trabalhos sobre fotossíntese, ali determinando o fator de transformação de energia trazida pelos fotões ao processo de fotossíntese. Wurmser foi um dos principais autores da trans-formação pós-pasteuriana que a biologia francesa experimentou após a guerra. Sua estada no Brasil, bem como a de Sabine, sua mulher, foi um sucesso. Serviu para a introdução da nova metodologia criada no após-guerra, assim como para a formação de novos cientistas, pois ambos eram bons orientadores e muito generosos na apreciação dos jovens aprendizes de ciência. E ainda deram vigor ao campo da biologia moderna entre nós. A presença do casal Wurmser no Rio de Janeiro, interrompida várias vezes para idas a São Paulo e a Minas Gerais, trouxe-nos benefícios incalculáveis. A afeição que dedicavam à terra francesa, berço de René e pátria adotada por Sabine, de origem romena, fez com que ambos vivessem os férvidos dias do fim da guerra numa intensidade angustiante, ainda que 
vivida com a certeza da vitória. Lembro-me da emoção de ambos, que era a de nós todos, antinazistas, no dia do desembarque das tropas aliadas na Normandia. Era a jogada final, da qual sairia ou a vitória da justiça e da razão, ou a destruição da liberdade. Por coincidência, passamos a noite na casa de minha mãe, com a qual morava minha avó, Maria Lobo, oitenta anos já passados, porém, a mais segura da vitória dos aliados, o que fazia com que ficasse com seu rádio ligado, até bem passada a hora da meia-noite, ouvindo a última emissão, em português, da BBC de Londres e pondo-se, assim, em contato com as últi-mas notícias da batalha que ocorria no continente europeu.

René Wurmser foi recebido com calor pela comunidade acadêmica brasileira. A sua modéstia e simpatia envolventes, bem como a vontade de prestar serviço, fizeram dele amigo de numerosos companheiros. Disto tenho conhecimento pelas visitas em que o acompanhei, a São Paulo e a Belo Horizonte. Tornou-se amigo de Georges Bernanos, com o qual passou vários fins de semana, em Paquetá, quando Bernanos deixou Barbacena para vir morar no Rio, segundo ele, para ficar mais perto da guerra. Wurmser admirava, profundamente, a francofilia do povo brasileiro, que os arroubos integralistas do governo não tinham conseguido arrefecer. Um dos episódios que talvez mais o ligaram ao Brasil passou-se quando de nossa volta de Belo Horizonte, onde havíamos ido participar de uma reunião científica. Ao pararmos em um pequeno restaurante em Itabira, para jantar fora de hora, o garçom começou a falar francês conosco. Wurmser, surpreso, perguntou-lhe como aprendera aquela língua. $O$ rapaz, timidamente, informou-lhe que nunca havia saído de Itabira, mas que aprendera francês porque a considerava uma língua de inigualável beleza. Bernanos, que estava conosco, e os Wurmser foram tomados de um irresistível choro convulsivo. Tempos mais tarde, quando Bernanos tomou o pequeno vapor que o levaria a Londres, fui acompanhá-lo até o cais. Ao voltar, pesou-me o coração. Sabia que perdia um sólido apoio, de todos os pontos de vista.

Alguns meses mais tarde, fiz de novo o caminho do cais, para levar o casal Wurmser ao navio que também tomaria o rumo da Inglaterra, onde René iria trabalhar no grupo de cientistas que se juntara ao general De Gaulle para combater a ocupação da França pelas tropas hitlerianas. Wurmser contoume, depois, a tensão em que ali viveram, sob a ameaça constante dos engenhos V1 e V2. 
A presença de René Wurmser no instituto abriu caminho para a minha intenção de trazer ao convívio dos meus colegas os grandes nomes da ciência internacional, o que foi uma linha seguida pelo Instituto de Biofisica, como já mencionei. Durante a guerra, essa comunicação internacional era bastante dificil, direi mesmo, quase impossível. Alguns cientistas americanos percorrendo a América Latina se detinham no Rio e era já o instituto que os acolhia. Um dos que mais tempo se demoraram em nossos laboratórios foi Keith Porter, da Universidade de Harvard, que foi ao laboratório de Hertha Meyer para verificar, de visu, a cultura de plasmódios em cultivo de tecidos. Nossa expectativa era sondar a possibilidade de uma cultura mais abundante que permitisse a obtenção de estudos avançados sobre a capacidade de formação de anticorpos nos animais de experiência, o que seria um caminho para a obtenção de uma vacina antimalárica - tanto mais necessária quanto essa endemia aumentava em todo o mundo e, particularmente, nas regiões asiáticas, para onde a guerra se havia estendido. Os plasmódios haviam se tornado resistentes a uma série de produtos químicos de uso habitual. $O$ fim da guerra determinou a cessação dessa linha de trabalho.

De um certo momento em diante, tornou-se fácil a obtenção de recursos para trazer ao Rio eminentes cientistas de maior ou menor projeção internacional. As fontes, como já dito, foram a Rockefeller Foundation, responsável pela vinda do casal Wurmser; o governo francês, por meio do Departamento Cultural do seu Ministério do Exterior; o British Council; a Unesco; e Guilherme Guinle. Evidentemente que, com a criação do Conselho Nacional de Pesquisas, tornou-se muito mais fácil o intercâmbio com os centros científicos do mundo.

Uma boa contribuição ao desenvolvimento do Instituto de Biofisica foi a estada, entre nós, de Giuseppe Occhialini. Quando o Brasil entrou em guerra contra os aliados de Hitler, a Universidade de São Paulo teve que romper o contrato de trabalho que tinha com Occhialini. Conhecedor do fato, comuniquei-me com este e ofereci-lhe as condições, que não eram faustosas, para trabalhar no instituto. Occhialini aceitou e, durante o período de quase um ano em que esteve conosco, foi mais do que um esplêndido companheiro. Habilíssimo experimentador, bom físico teórico, a sua exuberante maneira de ser e de viver deu aos nossos laboratórios impulsos em todas as direções. Occhialini era, além disso, um grande curioso, o que 
caracteriza o cientista de alto nível. Rapidamente tomou conta de muitas das nossas atividades e, com sua iniciativa e inventividade, utilizou uma grande parte da aparelhagem que havia caído em desuso, guardada nos grandes armários que ocupavam o maior espaço do nosso departamento. Seu interesse científico, naquele momento, era a obtenção de emulsões fotográficas capazes de observar reações nucleares de pouca energia. Para isso, Occhialini mobilizou, praticamente, todo o pessoal auxiliar do instituto. Entretanto, seu charme, sua graciosa ironia e o sorriso que sublinhava a extraordinária limpidez dos seus olhos verdes tornaram possível uma convivência perfeita, que nunca se deteriorou. Sua ansiedade pelo que se passava na Europa e o seu enraizado antinazismo tiravam toda a tranqüilidade que um momento de calma pudesse lhe dar. Sua carreira científica foi brilhante e sustenta-se que pelo menos um Prêmio Nobel dado a um cientista inglês foi conseqüência do trabalho de Occhialini, quando de sua passagem pela Inglaterra. Conta-se, também, que nessa admirável nação de grande projeção científica, como é hábito colocar-se, depois do nome, iniciais qualificativas do currículo ou de uma honraria concedida pelo governo de Sua Majestade, Occhialini passou a se assinar Giuseppe Occhialini A.U.F., em um deboche, evidentemente, pelo sistema adotado, pois as iniciais A.U.F. indicariam as palavras Atleta da Universidade de Florença. Era a sua agulhada no establishment acadêmico inglês. Occhialini teve atuação brilhante no Departamento de Física da Universidade de São Paulo, onde o conheci e onde trabalhavam Marcelo Damy de Souza Santos, Gleb Wataghin, Paulo A. Pompéia, entre outros de grande mérito. Foi ali que se iniciou Cesar Lates. O Departamento de Física atingira, rapidamente, desde a sua formação no momento da criação da Universidade de São Paulo, um alto nível científico e prestígio internacional e prestou uma colaboração extraordinária ao Instituto de Biofísica. Interessado pela aplicação de radioisótopos, mas com conhecimento apenas livresco das técnicas utilizadas, fui àquele departamento aprender aquilo de que precisava. Marcelo Damy me orientou e me mostrou como se preparava um contador Geiger, tendo me fornecido os primeiros que vim a utilizar e dando-me o projeto do controle elétrico do contador. Além do mais, emprestou-me uma fonte de radioberílio, com a qual pude preparar quantidades mínimas de radiofósforo, até que um acordo com Robley Evans permitiu-me receber radioisótopos dos Estados Unidos. As 
mínimas quantidades de radiofósforo obtidas em trabalho realizado por Moura Gonçalves permitiram determinar a fonte de fosforilação da fosfocreatina. Com a chegada de radioiodo produzido no ciclotron do MIT, o instituto pode iniciar estudos sobre funções tireoidianas. Em experiência extremamente fina, Antônio Couceiro pode retirar, de um só folículo, a secreção ali contida.

Os trabalhos em radioisótopos que marcam o início da utilização dessa técnica em nosso país tiveram boa repercussão no estrangeiro. Assim é que, em uma conferência feita no Colégio de França, eu os apresentei na presença de pesquisadores de alto padrão, entre os quais Jolliot Curie. Em conseqüência desses trabalhos, o instituto desenvolveu um laboratório de auxílio aos serviços de clínica médica, nos quais a utilização da técnica de radioisótopos, praticamente do radioiodo, tornar-se-ia corrente. O incremento da técnica foi devido à entrada, para o quadro do instituto, de Eduardo Penna Franca, o segundo graduado em química a ingressar numa instituição que, pelo conservadorismo de nossas universidades, devia ser destinada somente aos diplomados em medicina, já que o Instituto de Biofísica estava ligado à Faculdade de Medicina. Ao mesmo tempo, foi-me concedido um auxílio pela Fundação Rockefeller para a realização de um curso intensivo de treinamento na técnica de radioisótopos. Entrei em contato direto com o professor J.D.Cooper, da Universidade de Chicago, que veio auxiliar, no instituto, a organização do curso. Teve o mesmo grande êxito, tendo uma parte das vinte vagas sido reservada para pesquisadores da América Latina. $O$ curso repetiu-se durante os sete anos subseqüentes. A atividade comandada por Eduardo Penna Franca estendeu-se a vários centros hospitalares do Rio de Janeiro. Mais do que isso, permitiu a utilização dessa importante técnica en muitos dos projetos de pesquisa realizados no instituto.

Uma outra iniciativa foi a da criação de um laboratório de eletrobiologia celular, que complementaria as pesquisas sobre a atividade cardíaca em células em cultivo. Para tanto, foram concedidos, pelo doutor Augusto Trajano de Azevedo Antunes, presidente da Caemi (antiga Cia. Mineração e Metalurgia, atual Cia. Auxiliar de Empresa de Mineração S.A.), quatrocentos contos de réis, com os quais foram enviados, aos Estados Unidos, Antônio Paes de Carvalho e Walmor Carlos de Mello, sendo que este último fixouse naquele país, na qualidade de professor de fisiologia da Faculdade de Medicina de Porto Rico. 
O estudo do Electrophorus electricus foi um dos temas que deram prestígio ao instituto. Permitiu ele o desenvolvimento de várias técnicas. Depois de serem estudadas as características anatômicas do animal escolhido como modelo biológico de grande interesse - conforme dito anteriormente estudo do qual participou o então professor de anatomia da Escola Nacional de Agronomia, W. Duque Estrada Bastos, passou-se primeiro à análise citológica do sistema eletrogênico, para depois serem estudados os mecanismos determinantes da descarga. Um universo extremamente pouco explorado, que foi se desvendando graças a um trabalho científico do qual participaram inúmeros pesquisadores do instituto, devendo ser sublinhada a participação de Aida Hasson Voloch, Antônio Couceiro, Lauro Sollero, professor de farmacologia da Faculdade de Medicina, Anna Francisca Falcato Ribeiro, Manuel da Frota Moreira, Alberto Barbosa Hargreaves, Maury Miranda e outros mais, já que aos iniciantes de atividade científica no instituto era quase obrigatório o trabalho com um tema originário da atividade do Electrophorus electricus. Assim, pouco a pouco, foi estudada a estrutura do órgão elétrico, que serviu à introdução das técnicas de citoquímica no instituto, suas principais enzimas, a comparação, sob vários aspectos, de sua estrutura com a dos músculos, na procura da origem embriogênica do mesmo, servindo, também, o órgão elétrico para a introdução, no instituto, das técnicas de estudo do citoesqueleto. Além do mais, estudando a eletroplaca isolada, Richard Keynes e Hiss Martins Ferreira mostraram a importância do mecanismo de movimentação do sódio na produção da descarga elétrica. Uma parte da atividade com esse modelo biológico serviu, ainda, para o estudo da transmissão neuroefetuadora. Nesse setor, uma experiência de curarização do órgão elétrico mostrou uma dissociação entre a paralisação da capacidade de produzir a descarga e a curarização muscular. Essa experiência mostrava a possibilidade de o órgão elétrico do poraquê ser uma boa fonte para a identificação e caracterização do receptor da acetilcolina. Para isso, obtive, no Instituto Pasteur de Paris, um curare radioativo. Este se associa ao transmissor do impulso nervoso que, no caso da eletroplaca, é a acetilcolina. Também o órgão elétrico serviu para pôr em prática o uso da microscopia eletrônica, embora essa técnica tenha sido desenvolvida, principalmente, para estudar as características submicroscópicas do Trypanosoma cruzi, trabalho iniciado por Hertha Meyer, ainda com o primeiro microscópio Phillips adquirido. 
O órgão elétrico serviu também para experiências do efeito da desnervação nas estruturas íntimas das células. Mais ainda, desenvolveu-se toda uma nova linha de pesquisa: a da utilização de fărmacos radioativos para o estudo da sua ação e distribuição. A utilização de um curare radioativo permitiu inicialmente mostrar que um fărmaco injetado no organismo pode ser encontrado em tecidos onde não exerce atividade. Permitiu, também, a localização, pela radioatividade nas eletroplacas, dos complexos formados pelo curare com o receptor (a substância receptora), confirmando a proposição feita por A.J. Clark da existência de receptores. Em relação aos nossos trabalhos com a acetilcolina, Daniel Bovet escreveu um depoimento que também mostra a ambiência de fraternidade que sempre existiu no Instituto de Biofisica. Daniel Bovet assim se expressa:

Velletri 8.8.88

Cher Carlos,

Merci de ton précieux message. Cela a été interessant et émouvant d'évoquer avec toi la période quasi cinquantenaire de ces recherches sur l'acetylcholine et les curares qui ont si profondément marqué la neurophysiologie et la biologie contemporaine.

En evoquant nos collègues de cette époque, j'y vois de plus ou moins génereux, des génereux et des méchants.

Est-ce en raison du caractère fondamental et abstrait des problèmes soulevés, il me semble que plusieurs de ceux qui avec toi se sont attachés a ce problème ont été singulièrement peu génereux.

Toi et ton groupe avez representé une exception. Je me souviens et aime d̀ evoquer la generosité de tes invitations et de l'hospitalité que j'ai regue d Rio. Malgré la distance et la geographie, Rio a, grace d̀ toi, representé dans cette aventure du cholinergique le point de rencontre et d'échanges que ni Londres, ni New York, ni Paris n'ont su être.

Cela sera passionant que tu le racontât.

L'été ici est splendide, mais nous réjouissons tandis que vous êtes au travail.

A toi et aux tiens, Filomena et moi envoyons toutes nos amitiés.

Daniel Bovet

Seria impossível descrever todas as atividades científicas do instituto, que procurou sempre acompanhar o progresso científico, seja o que se faz através de novos conceitos e abre novas perspectivas, seja o que exige novas técnicas e novos instrumentos. É o caso, por exemplo, da biologia molecular, que vem se infiltrando em várias das atividades do instituto. 
O grupo de Marcello Barcinski realiza estudos imunológicos de grande interesse. A variação da patogenicidade de diferentes raças de agentes patogênicos tem sido estudada, com resultado extremamente interessante, por técnicas imunológicas.

Outro caso exemplificador é o da introdução da genética. Deu-se ela depois que foi verificado o aumento, estatisticamente provado, de modificações cromossômicas em indivíduos habitantes de terras de alta radioatividade ambiental, como as praias onde existe areia monazítica, e em indivíduos submetidos a uma alta radiação, como os pilotos que voam em grandes altitudes. $\mathrm{O}$ instituto, para tanto, criou um laboratório de citogenética e chamou, para o seu quadro, um grande especialista: José Carlos Cabral de Almeida, cujas qualidades de pesquisador e clínico logo se afirmaram e que vem desenvolvendo trabalhos de repercussão internacional. Formou-se, em sua volta, um grupo de jovens da mais alta qualidade científica, o que torna a citogenética estudada no Instituto de Biofisica conhecida internacionalmente.

Esse exemplo indica como o instituto, ao lado do desenvolvimento do conhecimento, interessa-se por problemas práticos, aos quais a ciência pode dar importante contribuição. No campo das ciências básicas, o instituto tem mais de mil e duzentas publicações feitas em revistas científicas nacionais e internacionais do mais alto padrão. Ao mesmo tempo, tem sido chamado várias vezes para resolver problemas de ordem prática. É o caso da pesquisa de doping em cavalos de corrida e da determinação, pelos raios $\mathrm{X}$, de fraturas na estrutura de grandes condutores hidráulicos. Do mesmo modo, nossa instituição se ocupa da contaminação, por metais pesados, das águas que se avizinham aos garimpos da Bacia Amazônica. Essa linha de pesquisa tem tido a maior repercussão nacional e internacional. $O$ instituto acompanhou, também, a contaminação radioativa da atmosfera no momento das explosões nucleares, realizadas experimentalmente pela França, no Pacífico, e a sua ligação com os problemas ambientais torna-se cada vez mais intensa. Citemse, ainda, estudos feitos por Luiz Renato Caldas, relativos a um pigmento que se encontra nas águas do rio Negro e que tem uma ação bactericida nítida.

Numerosos foram os pesquisadores estrangeiros - americanos, franceses, ingleses, italianos, alemães, espanhóis, portugueses, japoneses, australianos, dinamarqueses, belgas, holandeses, suecos, russos e latino-americanos que ilustraram a atividade do instituto, fazendo seminários, pronunciando 
conferências ou participando de trabalhos experimentais. Há cinco anos, a lista dos mesmos era da ordem de, aproximadamente, trezentos pesquisadores.

A atividade de aproximação do instituto com a comunidade científica internacional fez-se, ainda, pela realização de simpósios ou colóquios. Da lista dessas reuniões citarei, inicialmente, aquela que tratou dos mecanismos de curarização, em 1957, fazendo-se a parte de debates no Museu Nacional. Essa reunião deu origem àquela sobre bioeletrogênese (1959), realizada no Hotel Glória, com o que se inaugurou o hábito de se fazerem reuniões científicas nos hotéis em que se hospedam a maioria dos participantes. Desejo citar, ainda, a que estudou os vários aspectos da tireóide, trazendo ao conhecimento da comunidade científica os progressos interdisciplinares dos estudos sobre essa glândula, organizada por Luiz Carlos Lobo.

Essas reuniões internacionais são organizadas com a participação ativa de um dos pesquisadores do instituto, tendo como finalidade trazer ao público trabalhos ali realizados, pôr em contato os nossos cientistas com altos valores de cada campo tratado e, em menor grau, obter informações detalhadas dos laboratórios estrangeiros, onde nossos pesquisadores, jovens ou menos jovens, possam estagiar para formarem seu espírito ou aprender novas técnicas de trabalho. Esse intercâmbio, que completa a formação final de nossos pesquisadores no estrangeiro, foi essencial para o desenvolvimento do potencial científico humano que o instituto apresenta hoje.

Uma das preocupações das direções do instituto tem sido a formação de técnicos nos vários níveis laboratoriais. Infelizmente, algumas das tentativas iniciais fracassaram pela impossibilidade de serem mantidos, no quadro do instituto, os técnicos de certo nível, devido aos baixos salários pagos pelo governo. Quando iniciamos o uso do oscilógrafo de raios catódicos, por duas vezes tivemos técnicos treinados por nós, os quais, em pouco tempo, foram levados à indústria privada, com pagamentos salariais que não poderíamos enfrentar. Acredito, também, que na grande maioria de nossas instituições científicas, pelo menos até agora, os técnicos não fazem parte do que seria um quadro de paracientistas e seus nomes não chegam às publicações, que, provavelmente, não teriam sido feitas sem a sua colaboração. Nas atividades realizadas pelo Instituto de Biofísica, foi decisivo o auxílio prestado, entre outros, por Augusto da Silva e Wilton Batista de Paula, que recebiam o magro salário de servente. 
A criação da atividade de pós-graduação na universidade deu, ainda, um maior impulso à pesquisa no instituto. Nasceu essa atividade em nossa universidade graças à vinda ao Brasil de um diretor da Fundação Ford: Alfred Brown. Convidou-me, este, para um almoço na sede da representação da entidade à qual pertencia. Disse-me que a fundação pretendia passar a auxiliar a pesquisa em nosso país e perguntou-me o que eu achava que deveria ser feito. Respondi-lhe que, para mim, o ideal seria que a Fundação Ford ajudasse a Universidade Federal do Rio de Janeiro a implantar um sistema de pós-graduação, associando, ao mesmo, o Instituto Oswaldo Cruz, a Faculdade Nacional de Filosofia e o Museu Nacional, instituições essas onde encontrar-se-iam pesquisadores de qualidade. Depois de longas tratativas, o projeto foi realizado na universidade, graças à ação de Moniz de Aragão e Paulo de Góes, que participaram de uma comissão, organizada por Pedro Calmon, a meu pedido: a Comissão de Pós-Graduação e Pesquisa, e que deu origem à sub-reitoria com o mesmo nome. A verba inicial foi distribuída entre vários pesquisadores das instituições citadas, inclusive ao Instituto de Biofísica. Apenas um pesquisador, que não pertencia à universidade, declarou que não desejava receber recursos originários dos Estados Unidos. Todos os demais deram apoio à idéia e foram extremamente eficientes na instalação do sistema de pós-graduação, no Rio de Janeiro. À pós-graduação veio juntar-se o Conselho Nacional de Pesquisas, criado anteriormente, e, mais tarde, a Financiadora de Estudos e Projetos - Finep.

A pós-graduação permitiu a multiplicação de esforços no setor da pesquisa, trazendo aos nossos laboratórios, dentro das possibilidades de cada um, alunos de excelente qualidade no espírito e na ação. $O$ número de trabalhos cresceu, bem como o de teses, que têm a validade enriquecida pela boa apresentação geral do assunto escolhido para o projeto de pesquisa. Estas, para serem submetidas à apreciação de uma comissão, têm que ser originais. Esse critério foi também o adotado pelo instituto quando apresentou à Faculdade de Medicina, nos idos dos anos cinquienta, teses de doutoramento em medicina, julgadas, da mesma forma, por uma comissão de cinco examinadores, dois dos quais fazendo parte da congregação da faculdade, o que reviveu, com o caráter mais condizente e com o rigor de uma tese de doutorado, uma velha tradição daquele estabelecimento. Esse título foi obtido por vários dos pesquisadores atuais do instituto. Entre os doutores assim formados cite-se o 
nome de Jorge Braun Cantillo, da Argentina. Do mesmo modo, antes da criação da pós-graduação, o instituto procurou fazer com que seus pesquisadores obtivessem, por concurso, o título de livre-docente, sendo que doze assim o fizeram.

Entre os laboratórios do instituto que prestam serviços à comunidade científica do Rio de Janeiro, especial referência deve ser feita ao Centro de Microscopia Eletrônica, inicialmente organizado por Hertha Meyer e Raul Dodsworth Machado - este oriundo dos laboratórios do Ministério da Agricultura e especialista em óptica - e, posteriormente, desenvolvido de forma extraordinária, em pessoal e instrumental, por Wanderley de Souza.

Ao lado da atividade de pesquisa, o instituto desenvolve uma vasta ação de ensino. Pela disposição atual, cabe ao instituto ensinar as disciplinas de biofisica, fisiologia e parasitologia para todos os cursos da universidade que as tenham em seus currículos. Isto faz com que passem pelos anfiteatros e laboratórios da instituição, em média, quatro mil e quinhentos alunos de graduação por ano. Além desses, como o instituto mantém cursos de pósgraduação, mais de duzentos alunos de mestrado e doutorado freqüentam os seus laboratórios. A eles acresçam-se os estagiários de iniciação científica, em torno de cem, e, mais recentemente, os alunos do curso de formação à pesquisa biomédica.

Assim, o instituto vem desenvolvendo sua atividade dentro das normas que devem definir qualquer que seja a boa evolução social e econômica de um país. A universidade deve ser uma instituição de pesquisa, e, porque pesquisa, ensina, abordando os problemas essenciais de cada região e abrindo horizontes para o mundo, sem qualquer tipo de discriminação. Dessa forma, o Instituto de Biofísica contribui, decisivamente, para a cultura que deve ser o traço determinante da identidade de uma nação.

A atividade de pesquisa foi, também, incrementada pelas freqüentes viagens que fiz ao exterior, nas quais procurei conhecer o que de melhor se fazia, seja conceitualmente, seja tecnicamente, dentro dos campos de reflexão desenvolvidos no instituto. As viagens, de certo modo, complementavam a vinda ao laboratório dos cientistas que se reuniam para simpósios e em cursos especiais, como, por exemplo, o curso de perspectivas da biofísica, professado por vários pesquisadores de nomeada, entre os quais Severo Ochoa, Bernard e Alberte Pullman e John Eccles. O congresso sobre "curare 
e substâncias curarizantes" permitiu a vinda aos nossos laboratórios do casal Daniel Bovet e Filomena Bovet-Nitti, ambos do Istituto Superiore di Sanità, de Roma, e, assim, uma abertura para a ciência italiana em plena renovação do após-guerra. Em um trabalho no qual colaborou Daniel Bovet, publicado nos Anais da Academia de Ciências de Paris, indiquei ao mundo científico a importância do órgão elétrico do poraquê para o reconhecimento e a identificação do receptor colinérgico.

$\mathrm{Na}$ minha ida aos Estados Unidos para participar do comitê assessor de pesquisas da Organização Pan-Americana de Saúde, ou ainda à Suíça, onde fazia parte do Comitê de Pesquisas da Organização Mundial de Saúde, foime permitido tomar conhecimento íntimo da conexão entre as ciências básicas e os problemas de saúde. Do mesmo modo, foi-me extremamente útil o fato de ter sido eleito para secretário da Primeira Conferência para a Aplicação da Ciência e da Tecnologia ao Desenvolvimento, organizada pela ONU (19621963). A ela se seguiu a minha participação no Comitê das Nações Unidas para a Aplicação da Ciência ao Desenvolvimento. Essas duas últimas puseramme em contato com os problemas do crescimento científico dos países em desenvolvimento. Assinalo que o fato de tomar parte nesses colegiados só é significativo quando o seu participante dedica-se ao trabalho, analisa relatórios de atividades, deixando de lado o que se poderia chamar de "turismo científico", tão ao gosto de certos pseudocientistas, apadrinhados pela política reinante em seus países de origem. Essas incursões sempre foram curtas, pois era grande a minha ansiedade de voltar à Praia Vermelha.

Realizei duas viagens mais longas. Quando fui a uma reunião do Comitê da Organização Pan-Americana de Saúde, aproveitei para visitar alguns dos Iaboratórios da costa nordeste dos Estados Unidos. Devo acentuar a visita que fiz a Detlev Bronk, em Filadélfia, ao laboratório de Newton Harvey, em Princeton; ainda, ao Instituto de Macromoléculas, de Ephraim Katchalsky, em Brooklyn, e ao Centro Médico da Universidade de Columbia, no qual trabalhava David Nachmanson, com o qual estabeleci uma amizade muitas vezes tumultuada por discordâncias científicas. $\mathrm{Na}$ Universidade de Harvard visitei o Centro de Pesquisas Biomédicas. De cada uma dessas visitas, que se prolongavam às vezes por mais de três dias, tirei enorme partido. Foi uma experiência muito válida para o desenrolar da minha atividade científica, já que um dos grandes fatores de impedimento da pesquisa em nosso país era 
a distância que nos separava dos grandes centros de ciência do hemisfério norte e, também, de certos países distantes do hemisfério sul, como a Austrália e a Índia. Isto torna muitas vezes inviáveis, ainda hoje, nossos projetos de pesquisa, nos quais a troca de informações é sempre um fator valioso de progresso. À distância junta-se, ainda, a incompreensão da importância da ciência para o desenvolvimento social, o que é um dos traços da "incultura" nacional.

A outra viagem, do maior interesse para os trabalhos que se desenvolviam no Instituto de Biofísica, me levou a permanecer quase dois meses no Istituto Superiore di Sanità, onde, na companhia de Daniel Bovet, familiarizei-me com os despolarizantes de membranas, alguns dos quais, por isso mesmo, têm ação curarizante. Pude, assim, comparar a eletrogênese do Torpedo com a do Electrophorus electricus (L.).

A participação na Primeira Conferência Geral da Associação Internacional das Universidades, de cujo primeiro conselho fiz parte, permitiu-me, pela comparação que pude fazer entre os vários modelos universitários de todo o mundo, alargar a minha idéia do que deva ser realmente uma universidade, preocupada, de um lado, com os problemas nacionais, e atenta, do outro, com o que se passa nas universidades de outros países. Isto é condição indispensável para que se possa contribuir para a cultura nacional.

$O$ desenvolvimento científico do Instituto de Biofísica fez-se não só pelo interesse que os jovens e menos jovens que o procuraram - e ainda o procuram - tinham pelo conhecimento científico, quanto pelo estabelecimento quase-obrigatório do tempo integral, com o qual se desenvolveu a ciência nos países de proeminência científica e na época já implantado na novel Universidade de São Paulo (USP). Escrevi "quase-obrigatória" porque, em alguns casos, raríssimos, permiti atividades fora do instituto, mas que eram de interesse para nossa instituição. A acumulação de funções era a conseqüência dos baixos salários oferecidos aos professores e pesquisadores.

Para resolver o problema dos membros do Instituto de Biofisica e da comunidade científica em geral tomei duas iniciativas, ao longo do tempo. A primeira foi a solicitação feita à Fundação Rockefeller de bolsas complementares para os pesquisadores da universidade. A fundação aceitou imediatamente a proposta, concedendo as bolsas pedidas. Essa iniciativa foi, entretanto, interrompida pela própria fundação, devido ao protesto pela extrema lentidão com que, dentro da universidade, eram repassados os 
montantes já concedidos pela organização americana aos beneficiários. A atitude da Fundação Rockefeller foi a natural conseqüência do grande protesto feito por um dos beneficiados, inclusive por meio dos jornais.

A segunda iniciativa que tomei foi a de solicitar ao presidente do Dasp, Luís Simões Lopes, que aquela organização, que dominava o cenário administrativo do país, determinasse o meio pelo qual as instituições universitárias e científicas pudessem estabelecer, para seus quadros, o sistema de trabalho em tempo integral. Luís Simões Lopes aceitou, com entusiasmo, a minha proposta, que não chegou a termo devido às várias denúncias de que membros do corpo docente não compareciam aos seus laboratórios, por dias a fio. O problema, entretanto, foi resolvido inicialmente com a criação do Conselho Nacional de Pesquisas, no qual, sob a direção de Álvaro Alberto, foram criadas as bolsas de complementação, que exigiam atividade em tempo integral. Pena que essa medida não tenha sido tomada no momento em que foi promulgada a Constituição de 1938 e a proibição de qualquer tipo de acumulação tivesse afastado de suas atividades muitos de nossos melhores pesquisadores, os quais não tiveram compensada, por um aumento de vencimentos, a perda parcial de seus rendimentos.

A necessidade do tempo integral custou muito a ser aceita pelas políticas governantes. Lembro-me de uma reunião havida em Washington, em março de 1962, como parte do Programa de Boa Vizinhança, idealizado por John F. Kennedy. Éramos vinte e um representantes dos países das Américas Latina e do Norte. A proposta de adoção do tempo integral mereceu contestação da maior parte dos delegados presentes, manifestandose a favor da mesma, abertamente, somente os representantes da Argentina e do Brasil, os dois únicos cientistas do grupo, ele fisico e eu biologista. No Brasil, a primeira instituição a adotar o tempo integral foi a Universidade de São Paulo, a começar pela Faculdade de Medicina - para seus departamentos básicos - e a Faculdade de Filosofia, Ciências e Letras, fundada logo depois de criada a USP. A Fundação Rockefeller desejou estabelecer o tempo integral para as cadeiras básicas da Faculdade de Medicina da Universidade do Brasil. Não o fez porque nenhum dos professores visados prontificou-se a exercer a sua atividade em tempo integral.

As dificuldades para manter o quadro do Instituto de Biofisica em tempo integral, antes da criação do CNPq, foram obviadas na Faculdade de Filosofia 
da Universidade do Brasil pela compreensão de Aluisio de Mello Leitão, com a criação das disciplinas fisiologia comparativa e bioquímica, entregues a pesquisadores do Instituto de Biofísica, entre os quais Aristides Azevedo Pacheco Leão, a primeira, e a segunda, a Maury Miranda. Isto só foi possível porque a nova Constituição passou a permitir a acumulação de uma função docente com outra da mesma característica, ou com uma função técnica.

Sempre pensei que o tempo integral fosse o fertilizador de uma carreira científica. Elevado por concurso a ocupar uma cátedra na Faculdade de Medicina, malgrado dificuldades materiais, recusei sempre aceitar funções definitivas fora dos locais onde exercia a minha atividade de professorpesquisador. Assim é que não aceitei participar de concursos para outras cadeiras e nem mesmo exercer atividades clínicas, dentro de minha competência, na biofísica médica. Entretanto, convidado por Joaquim da Costa Ribeiro, não me neguei a ser diretor do Setor de Biologia do Conselho Nacional de Pesquisas, do qual Costa Ribeiro era diretor científico. Minha aceitação, todavia, foi condicionada a que toda a minha atividade fosse exercida na Praia Vermelha, excetuadas as ocasiões nas quais reuniões me obrigariam a ir à sede do conselho, na avenida Marechal Câmara, ou naquelas a que fosse obrigado a visitar instituições de pesquisa situadas fora do Rio. Nestas iria com o fim de verificar suas condições de trabalho e a sua adequação à solicitação de auxílio formulada.

Afastei-me, parcialmente, do instituto, em circunstâncias que até hoje dilaceram o meu coração. Como já contei, em uma certa manhã de novembro de 1940, precisamente no dia 8, Evandro pereceu num desastre de avião, em plena enseada de Botafogo. Em consequiência, fui indicado por Getúlio Vargas, a pedido dos colaboradores de meu irmão, para assumir a direção do Serviço de Estudo das Grandes Endemias (Sege), que ele criara no Instituto Oswaldo Cruz.

A história desse serviço não foi ainda exposta de maneira suficiente e, assim, ouso descrevê-la rapidamente. Evandro Chagas, livre-docente de medicina tropical e pesquisador do Instituto Oswaldo Cruz, notou esmorecimento nos trabalhos realizados sobre doenças tropicais em nosso país. Procurou Guilheme Guinle que, na sua benemerência, prometeu patrocinar o projeto de meu irmão. Este obteve, ainda, a promessa de cooperação da Força Aérea 
Brasileira. Munido desses dois apoios, Evandro começou a verificar as condições nosológicas do país, percorrendo-o do Norte ao Sul. Em cada local em que o avião pousasse, Evandro convocava a classe médica e as autoridades para a realização de uma obra sanitária conjunta. Muitas vezes a sua ação se estendia a áreas vastíssimas. Assim é que repetiu, em 1939, o inquérito sanitário da Bacia Amazônica que meu pai fizera em 1910, visitando todos os locais que haviam sido examinados e constatando, apenas, pequena variação nos índices perquiridos e entre os valores observados por Chagas e os que ele obtivera. Sua presença teve ainda a conseqüência de entusiasmar alunos das faculdades de medicina e jovens de todas as regiões que visitou. Evandro foi, sem dúvida, um grande portador da mensagem da ciência a serviço do homem. Numerosos foram os postos de atendimento a doentes portadores das mais variadas moléstias infecto-contagiosas. Leishmanioses, visceral e tegumentária, esquistossomose, malária e doença de Chagas, além de outras, foram alvo do interesse do Serviço de Endemias. Assinale-se o posto que esse serviço manteve em Bambuí, onde, em menos de um mês, foram vistos mais casos agudos de doença de Chagas do que aqueles que nosso pai vira durante os dois anos em que esteve em Lassance. Quero, ainda, acentuar o entusiasmo com que, até hoje, cinqüenta anos depois de sua morte, o nome de Evandro é reverenciado.

Os colaboradores de Evandro Chagas, continuando a sua obra, deram vastíssima contribuição à patologia tropical, bastando citar Emmanuel Dias e Lobato Paraense, entre muitos. Evandro tinha as características que melhor marcam o verdadeiro cientista: o total despojamento de bens materiais, uma profunda obsessão pelo trabalho científico que realizava, uma genuína curiosidade por tudo aquilo que ocorre na natureza e um apegado desejo de servir a seu país.

Os dois anos em que permaneci como diretor do Sege foram de atividade exauriante. Chegava ao hospital às oito e meia da manhã para estar na Praia Vermelha às quatorze horas. Praticamente todos os dias passava tempo variável no Dasp, pois minha função principal era inserir o serviço, ou pelo menos os seus técnicos, no quadro das atividades federais, para o que encontrei o apoio de Gustavo Capanema, ministro da Educação e Saúde, Luís Simões Lopes, presidente do Dasp, e Cardoso Fontes, diretor do Instituto Oswaldo Cruz. A verba despendida por Guilherme Guinle, na ocasião, era de quatrocentos contos de réis por mês, e foi, para mim, uma satisfação comunicar 
ao grande benemérito a transferência do serviço de sua responsabilidade para passá-la ao governo federal.

Esgotei-me, realmente, nessa atividade cheia de preocupações e de responsabilidades. Não sei como adquiri uma infecção pulmonar que foi sanada pelo emprego intravenoso de Gadusan e, com a minha ida, em 1942, para a Granja das Margaridas, a duas léguas de Barbacena, pequena propriedade rural pertencente ao meu cunhado Virgílio de Mello Franco. Cheguei a Barbacena com acessos de febre alta todas as tardes, mas também com a curiosidade de conhecer Georges Bernanos, cujos livros me haviam impressio-nado fortemente e que ali fixara residência num sítio denominado Cruz das Almas. A primeira vez que o vi foi na Igreja Matriz de Barbacena, onde me parecia estar vituperando num português de difícil compreensão o religioso que estava dentro do confessionário. Achei estranhíssimo o fato e só mais tarde, quando melhor conheci Bernanos, vim a compreendê-lo. Era um dos seus momentos de ira, nos quais a razão estava, na maioria das vezes, ao seu lado.

Alguns dias mais tarde, sentado na sala de estar na Granja das Margaridas, ouço o tropel de ferraduras batendo no cascalho. Aproximei-me da porta e vi, descendo de um belo alazão, o próprio Georges Bernanos. Era um homem fascinante, cabeça de extraordinária força, o perfil marcadamente delineado e os revoltos cabelos grisalhos completavam a figura excepcional desse escritor que trazia a poesia na alma e o ardor do combate pela boa causa no coração. A irradiação da sua personalidade não era de nenhum modo atingida pela deformação física de seu corpo, conseqüência de um acidente de motocicleta ocorrido durante a guerra. Recebi essa visita, diariamente, durante os quase cem dias que passei nas Margaridas. A princípio, as visitas eram seguidas de um aumento de minha temperatura, em razão da veemência das posições de Bernanos e a minha discordância de certos conceitos por ele defendidos. As divergências eram mínimas e o acordo perfeito em relação às questões principais do dia. Assim, por exemplo, quanto à guerra que se desenrolava no Velho Continente ou na condenação do marechal Pétain, assunto no qual a ira de Bernanos não tinha limites. Também em relação aos problemas sociais de nosso tempo e, do mesmo modo, nas questões religiosas, nas quais a sua posição era mais agressiva do que a minha. Esmiuçando a memória, não encontro em Bernanos, já amadurecido após sua vivência na guerra da Espanha, nenhum traço do 
pensamento "mauraussiano", ou o eco de um camelot du roi. Bernanos completou, em mim, o desenvolvimento cultural que se iniciara com a leitura, entre outros, de Mauriac, Green, Proust, Faulkner, Dostoievski e dos poetas ingleses. Mais do que isso, Bernanos deu-me uma nova concepção da Igreja, muito mais livre e compreensiva do que aquela que a severidade dos padres de Oliveira e da Igreja do Largo do Machado me haviam imposto. Creio que o conceito de religião, para Bernanos, se encontre definido, em parte, em um apólogo incluso em carta que me mandou. Assim dizia:

Em uma certa ilha isolada habitavam três ermitãos já de idade avançada. Encontravam-se os três na praia quando viram que, lançado ao mar de um navio ancorado a distância, para eles se dirigia um pequeno bote. Chegado à praia, dele saltou um prelado acompanhado de dois ou três serviçais. Aproximou-se deles e perguntou: "Que fazeis, sozinhos, nestas paragens?" Os três eremitas responderam-lhe em uníssono: "Rezamos, Excelência." "Bela coisa", respondeu-lhes o prelado. "Vamos então rezar juntos o Pater." Os três entreolharam-se e, no fim de algum tempo, disseram ao bispo que não o sabiam de cor. "Não seja por isso", respondeulhes o bispo. "Vamos ensiná-lo a vocês." Logo depois de terminado o ensinamento, o prelado voltou ao navio. Antes que este partisse, o prelado os viu andando sobre as águas e aproximando-se da nave. Preocupado, perguntou-lhes o que poderia fazer por eles. Responderam-lhe que voltasse a lhes ensinar o Pater, pois haviam esquecido o que tinham aprendido pouco antes.

Na carta que me escreveu, Bernanos atribui o apólogo a Tolstói. Procurei encontrá-lo numa edição das obras completas desse autor. Em vão.

Os arroubos anti-semitas de Bernanos não atravessaram com ele o oceano. Por esse prisma tive com Bernanos vários entreveros. Impensadamente, como ele mesmo me disse, em sua crônica semanal, atacou a comunidade hebraica porque um grande professor israelita, da PUC, escrevera um artigo em defesa do marechal Pétain. Não aceitei os seus argumentos, puramente passionais, sentindo-me até atingido, pois meu laboratório abrigava um certo número de cientistas hebreus, nacionais ou aqui exilados, e entre estes René e Sabine Wurmser, com os quais, algumas semanas depois, Bernanos estabeleceu laços de amizade que perduraram até o seu desaparecimento. Creio que a convivência de Bernanos com os Wurmser apagou de sua alma essa nódoa discriminativa. 
Durante os meses que passei em Barbacena, o Laboratório de Biofísica, naturalmente, não me saía do pensamento. No correr do último mês, com o meu restabelecimento assegurado, comecei a pensar em como deveria administrar o laboratório, mais tarde transformado em instituto universitário, como já disse, por meio do decreto-lei $\mathrm{n}^{\circ}$ 8.393, de 17 de dezembro de 1945. Cheguei à conclusão de que, como diretor do instituto, algumas regras gerais deviam me conduzir. Em primeiro lugar, colocar o mérito científico acima de qualquer outra consideração, tal como parentescos, influência política e outras quaisquer; outra norma seria a de prestigiar os jovens que mostrassem marcante vocação científica, criando, para tanto, unidades de trabalho que deveriam dirigir; procurar, o mais possível, o intercâmbio entre os vários setores do instituto, através da criação de programas de pesquisa que exigissem a colaboração de pesquisadores de áreas de formação diversas; estabelecer contatos com as instituições de fora e de dentro do país e, para tanto, promover simpósios de alto nível, com a participação de pesquisadores do instituto e de instituições estrangeiras; procurar atrair para o nosso convívio somente jovens de indubitável tendência científica e, além do mais, mostrar a necessidade de o pesquisador ensinar, organizando a vida institucional de modo que seja ele um participante de suas atividades de ensino, sem barragem do tempo destinado à pesquisa, levando-se em conta que a universidade "é uma instituição de pesquisa, e, porque pesquisa, ensina"; e considerando, ainda, que o ensino bem elaborado é uma fonte enriquecedora de conhecimentos do próprio pesquisador.

A criação de inúmeras unidades de pesquisa no Instituto de Biofisica foi consequiência de fatores diversos. Um deles, a necessidade de introduzir em nosso meio uma tecnologia fisica que os laboratórios de biologia do hemisfério norte já estavam usando. O outro, a necessidade de dar oportunidade a jovens que, à medida que os meses passavam, em maior número vinham procurar o instituto. A princípio eram, todos eles, estudantes de medicina, mas, logo a seguir, vieram os de outras unidades da universidade, particularmente da Faculdade de Filosofia. O Instituto de Biofisica tornara-se, assim, um pólo de interesse científico para os jovens do Rio de Janeiro. A dispersão, mais aparente do que verdadeira, criticada por muitos e, até mesmo, por participantes dos nossos quadros, era a conseqüência da necessidade de dar ao nosso campo de estudos a flexibilidade indispensável 
à obtenção de resultados significativos. A biofisica deve ser definida como uma disciplina conjuncional que dá o baseamento às demais disciplinas biológicas e estabelece entre elas laços de compreensão e de interpretação, situando-se, assim, distante do conceito primitivo que admitia ser ela, no máximo, o estudo das aplicações dos conhecimentos e da tecnologia da física, dissociada da análise do fenômeno biológico, fundamento do ser humano.

Uma das características da atividade do instituto foi a sua continuidade. Sábados e domingos, ou dias feriados, nunca foram motivo para meus companheiros deixarem de ir ao casarão cor-de-rosa da Praia Vermelha. Esse regime, que na ocasião era uma exceção, não foi fãcil de ser estabelecido. Lembro-me da dificuldade que tive em obter as chaves do grande edifício da Faculdade de Medicina, onde se alojava o instituto, cujas portas abriam-se às oito horas da manhã, para se fecharem às dezessete horas.

Um admirável funcionário era o guardião da faculdade e nela habitava em uma pequena série de cômodos. Tornara-se um amigo desde os meus tempos de calouro, mas custou a aceitar a nova medida que, naturalmente, o preocupava, pois, além de perturbar o seu repouso, permitiria a um indesejável, que se apossasse da chave, penetrar no edificio. Esse fato arrefeceu nossa amizade, que, só muito mais tarde, veio a se restabelecer.

Os anos que se seguiram foram de crescimento constante e de produção científica apreciável. A partida de Sabine e René Wurmser, obrigados a sair do Brasil com destino a Londres, deixara um vazio, mas este foi compensado pelo entusiasmo com que o jovem grupo de pesquisadores que me cercava enfrentava, dia e noite, suas tarefas e dificuldades de toda ordem e que tantas vezes perturbavam a marcha dos trabalhos. $\mathrm{Na}$ organização administrativa do instituto tive a ajuda de Manuel da Frota Moreira, que a ela se dedicou integralmente, e também de nossa secretária Ana Maria Leão Teixeira, a Donana, como a chamamos. Quero assinalar, novamente, o quanto devo a dois auxiliares, técnicos de laboratório ou serventes, Augusto da Silva e Wilton Batista de Paula. Augusto era um grande conhecedor de anatomia humana e dava cursos de recuperação para os estudantes de medicina. Era um extraordinário mestre em dissecar peças anatômicas e foi quem realmente me ensinou o que se chamava, então, anatomia operatória, disciplina na qual tive "distinção", graças exclusivamente aos seus ensinamentos. Foi assim, 
com surpresa, que o recebi quando, logo depois de nomeado professor, pediu para ir trabalhar comigo. Ponderei-lhe que no Instituto de Biofisica não poderia ele ter turmas de alunos para ensinar anatomia, que certamente muito o auxiliavam na vida. Disse-me ele que manteria pequenos cursos na Escola Hanemaniana, mas que desejava, realmente, trabalhar comigo. Nada o demoveu e, assim, pude contar com a sua inestimável colaboração até a sua morte. Nunca soube como ajudá-lo e nem pude lhe manifestar a minha gratidão pelo seu gesto de simpatia e amizade.

Volto a focalizar Hertha Meyer que, exilada por Hitler, fora trabalhar em Turim com Giuseppe Levi. Posteriormente, pois de novo perseguida pelas leis raciais do fascismo, viera para o Brasil, onde já se encontrava sua família. Aqui obteve colocação no laboratório de fabricação de vacinas antiamarílicas, mantido pelo Instituto Oswaldo Cruz em cooperação com a Rockefeller Foundation. Informado de sua presença naquela instituição por Eudoro Villela, convidei-a, como já assinalei, para vir dirigir nosso Laboratório de Cultura de Tecidos, até então sob a responsabilidade de João Machado, que o instalara. Hertha Meyer desenvolveu notável atividade no instituto. Deu início ao cultivo contínuo do Trypanosoma cruzi em culturas de tecidos, trabalho que alguns anos antes havia sido apenas iniciado por Kofoid, nos Estados Unidos. A essa linha de pesquisa, Hertha Meyer deu admirável contribuição pelo número de trabalhos publicados, comunicações a congressos e, até mesmo, por um filme de oito milímetros premiado pela qualidade do trabalho realizado, no qual vê-se a penetração do parasito numa célula, sua transformação em amastigota, a eliminação de formas flageladas oriundas da multiplicação dos corpúsculos leishmaniformes, e a entrada dos tripanossomas metacíclicos em células não parasitadas. A microcinematografia permite observar todas as etapas do ciclo do tripanossoma no interior das células parasitadas. Esse trabalho foi feito graças à doação ao instituto, pela Organização Mundial de Saúde, de uma instalação Zeiss de microfilmagem. Hertha Meyer se destacou, ainda, por sua capacidade de formação de pesquisadores e técnicos especializados. Foi com a colaboração de Hertha Meyer que Rita Levi-Montalcini conseguiu identificar, de maneira definitiva, o Fator de Crescimento de Nervos (NGF). Assim aconteceu: recebi, um dia, uma carta de Levi-Montalcini perguntandome se, com o patrocínio da Fundação Rockefeller, poderia ela vir ao Brasil trabalhar com Hertha Meyer, que conhecera no período da perseguição anti- 
semita, no laboratório de Giuseppe Levi. Naturalmente, aquiesci ao pedido. Alguns meses depois, trazendo consigo dois camundongos portadores de nódulos de sarcoma de Rous, Montalcini chegou ao Brasil para começar a trabalhar, o que fez no dia seguinte. Colocando em cultura um gânglio embrionário e um pedaço do referido sarcoma, a experiência foi positiva em vinte e quatro horas. Numerosíssimos eram os dendritos que brotavam do gânglio. A experiência testemunha que, numa preparação na qual o sarcoma não fora colocado, mas somente o gânglio, este não indicou crescimento de nenhum dos seus componentes. Ficou assim provada a existência do Fator de Crescimento de Nervos.

Além do estudo do Trypanosoma cruzi em cultura de tecidos, Meyer realizou, também com a mesma precisão, o estudo do Toxoplasma gondii, assim como das formas extracelulares de alguns plasmódios. Essa linha suscitou grande interesse pois, na ocasião, os exércitos das forças aliadas, combatendo no Pacífico, faziam face à terrível epidemia de paludismo. Três fatores agravaram a situação. Primeiro, a quantidade de quinina era extremamente limitada pela falta de produção adequada; em segundo lugar, os anofelinos transmissores já mostravam resistência aos inseticidas usuais; do mesmo modo, os plasmódios, à quinina. Enfim, a idéia de uma vacina era mítica. Seria possível desenvolver uma produção maciça de plasmódios que permitisse estudos imunológicos destinados à produção de uma vacina? Era a pergunta que os imunoparasitólogos faziam a si mesmos. Durante duas semanas, o Instituto de Biofisica foi visitado pelo professor Keith Porter, do Departamento de Bioquímica de Harvard, que desejou conhecer in loco a realidade desse caminho.

Eduardo Penna Franca fora enviado aos Estados Unidos como bolsista do CNPq para se aperfeiçoar no estudo da aplicação de radioisótopos à biologia e à medicina. Voltando ao Instituto Oswaldo Cruz, não teve esta nobre instituição condições de fornecer-lhe o material necessário ao desenvolvimento das técnicas com que se familiarizara na América. Passado um longo período e como o conhecia bem, pois fora eu quem opinara para sua bolsa no CNPq, achei que poderia convidá-lo para o Instituto de Biofisica. Penna Franca a ele se integrou e teve participação definitiva no estudo da ação biológica das areias monazíticas do Espírito Santo, detalhada adiante, e na determinação das características radioativas do tório e urânio nos minerais 
do morro do Ferro, no planalto de Poços de Caldas. Deve-se a ele a determinação da poluição radioativa da atmosfera em conseqüência das explosões nucleares no Pacífico - produzidas experimentalmente pela França - , trabalho anteriormente citado, bem como o desenvolvimento da área de biofisica ambiental do instituto, o qual tornou-se um dos primeiros laboratórios latino-americanos especializados em radioecologia. Agora dirigido por Wolfgang Pfeiffer, nele estuda-se a contaminação por mercúrio nos garimpos da Bacia Amazônica, mercúrio este utilizado para amalgamar o ouro retirado do fundo da corrente e encontrado, não só nos animais domésticos e selvagens, como também nos seres humanos, em concentrações que chegam aos limites da periculosidade. A Penna Franca coube, também, a criação de clínicas de medicina nuclear, no Rio de Janeiro, voltadas para o diagnóstico e a terapêutica de disfunções tireoidianas.

Numerosas têm sido as linhas de pesquisa que utilizam isótopos radioativos. Começaram, as mesmas, com dificuldades que pareciam insuperáveis, com o estudo da fosforilação do ATP e, logo a seguir, com aquele da formação do colóide tireoidiano e sua indução pelos fármacos competentes. Coube a Antônio Couceiro a obtenção, por microextração, de quantidades mínimas do colóide de folículos vivos.

Alberto Barbosa Hargreaves, bioquímico, veio, também do Instituto Oswaldo Cruz, enriquecer nossos quadros. Com Manoel da Frota Moreira, que foi, por assim dizer, o vice-diretor do instituto até a sua ida para chefiar a Divisão Técnico-Científica do CNPq e, mais tarde, tornar-se secretárioexecutivo da Fundação Universitária José Bonifácio, Hargreaves determinou o conteúdo em sais minerais e em elementos orgânicos do sangue do Electrophorus electricus, o que permitiu a larga experimentação que veio a se fazer com porções do órgão elétrico perfundidas.

Aida Hasson Voloch veio, com Maury Miranda, completar o grupo de bioquímicos do instituto.

Maury Miranda foi, possivelmente, o jovem pesquisador de maior criatividade científica que conheci e um dos mais brilhantes jovens que vieram ao meu encontro. Disse-me Guzmán-Barron, com quem Maury Miranda estagiou, ser ele uma das inteligências científicas mais significativas que ele jamais encontrara, dizendo-me ainda que, a qualquer momento que Maury quisesse, poderia trabalhar em sua equipe, nas melhores condições 
que eram oferecidas a um pesquisador de renome, nos Estados Unidos. Nele a grande intuição era, entretanto, prejudicada pela imensa curiosidade que, se não disciplinada, leva certamente a uma dispersão de esforços e a uma descontinuidade na atividade laboratorial.

Aida Hasson Voloch, formada em química, tornou-se de imediato uma força ativa no instituto, aprendendo com rapidez técnicas ainda não conhecidas e vivenciando, como próprias, todas as preocupações e dificuldades que caracterizam o cotidiano de uma instituição científica. No seu trabalho de pesquisa encontra-se a precisão do detalhe, que é a própria ética da investigação, e a simplicidade do traçado experimental, que é a estética do mesmo. Aida Hasson participou, desde a sua entrada para o instituto, da pesquisa sobre o Electrophorus electricus (L.). É ela hoje uma profunda conhecedora dos mecanismos que o animal utiliza para defesa e ataque e para outras atividades biológicas. Aida Hasson Voloch, ao estudar a bioquímica do peixe-elétrico, tem posto em prática várias técnicas até então não utilizadas em nosso meio. Seu principal esforço tem sido o de caracterizar o receptor da acetilcolina. A importância do órgão elétrico para esta pesquisa nasceu de uma experiência de curarização do Electrophorus electricus na qual demonstrei que, enquanto a curarização muscular (dose-dependente) é de curta duração - podendo chegar até a vinte minutos nas doses utilizadas -, o desaparecimento da descarga pode durar até vinte e quatro horas. Tal fato indica a retenção no órgão elétrico do curare injetado endovenosamente, e permite admitir a existência de uma substância - o receptor - capaz de apreender a acetilcolina, agente transmissor do impulso nervoso ao efetuador, no caso o órgão elétrico. A notícia científica que mandei para a Comptes Rendus de l'Académie des Sciences de Paris foi publicada com muita lentidão porque foi boicotada por um professor de grande notoriedade, Louis Lapicque, que pensava que o trabalho pudesse trazer problemas para a aceitação da sua teoria da "cronaxia". A participação da acetilcolina na descarga elétrica foi por mim demonstrada em trabalho no qual se vê que a concentração de acetilcolina em um órgão diminui proporcionalmente ao número de descargas provocadas. Inversamente, com a diminuição da frequiência de excitação, o processo de destruição desse transmissor se modifica, reduzindose de forma progressiva. Foram também investigadas as principais enzimas do órgão elétrico, seja por técnicas bioquímicas correntes, do que se ocupou 
Aida Hasson e seu grupo, seja por citoquímica, pesquisa esta iniciada por Antônio Couceiro, de um lado, e Anna Francisca Falcato Ribeiro, de outro. $O$ órgão elétrico é um bom modelo experimental para o estudo da desnervação. Esse processo tem sido utilizado para estudar, em diferentes planos, a desagregação molecular e as disfunções conseqüientes à desnervação. Um dos campos também abertos à investigação é o da determinação da origem embrionária do órgão, cuja similitude com os músculos bilaterais de outras espécies é o primeiro indício de uma matriz embrionária comum aos órgãos elétricos - sobretudo o principal - e aos músculos. Para esse estudo, Vivaldo Moura Neto e o seu grupo têm usado, principalmente, a caracterização do citoesqueleto através de uma observação comparativa entre os vários órgãos do poraquê e músculos de órgãos de outros espécimens animais.

Vivaldo Moura Neto é uma das aquisições mais ou menos recentes do Instituto de Biofisica. Formado na UERJ, obteve o seu mestrado no Instituto de Química da UFRJ e o doutorado na Universidade de Paris, depois de quatro anos de freqüência no Collège de France e no Institut Pasteur. Introduziu em nosso meio o estudo do citoesqueleto, tornando-se, em pouco tempo, um dos melhores especialistas no assunto em toda a América Latina. Ao lado das suas qualidades de pesquisador, Vivaldo Moura Neto junta a de orientador pela sua comunicabilidade, especialmente com os jovens, tendo sido numerosas as teses realizadas sob sua orientação, nos poucos anos que tem de trabalho no Instituto de Biofísica.

A idéia de usar uma espécie biológica como modelo tem sido levada ao campo da parasitologia, sendo que, utilizando-se principalmente técnicas imunológicas, foram determinadas características reacionais, principalmente de cepas de tripanossomas e leishmanias. Tal idéia tem como objetivo a possibilidade de serem determinadas raças de alto poder imunogênico e pequena atividade patogênica. Entre outros pesquisadores que se ocupam desse assunto, quero citar Mécia Maria de Oliveira e Júlio Scharfstein.

O Setor de Neurobiologia, que em princípio tem como linha determinante a depressão alastrante, teve um despontar de grande repercussão: a publicação de um mapa estereostático do cérebro do gambá - Didelphis marsupialis. Em edição magnífica, esse trabalho, aplaudido por todos os eletrofisiologistas que estudam didelfideos e outros animais marsupiais, foi realizado por Carlos 
Eduardo da Rocha Miranda e Eduardo Oswaldo Cruz. Outras atividades importantes no campo da fisiologia cerebral foram também conduzidas pelo grupo de especialistas do Instituto de Biofisica, entre eles Roberto Lent, Raphael Linden, Leny Cavalcanti etc. Mais recentemente, ficou demonstrado por Ricardo Gattass e colaboradores que a excitação visual traz, no local tecidual de sua ação, uma modificação do metabolismo. $O$ caso estudado é $o$ da citocromo oxidase.

O instituto esteve sempre muito próximo do Departamento de Farmacologia e numerosos foram os trabalhos publicados em conjunto por componentes dos dois centros. Foi associado ao professor Lauro Sollero, titular de farmacologia da Faculdade de Medicina, que empreendi uma iniciativa que a muitos pareceu leviana. Tendo sido um dia chamado pelo presidente do Jockey Club Brasileiro, Francisco Eduardo de Paula Machado, para me empenhar na solução do problema do doping em cavalos de corrida, que fazia com que muitos fármacos escasseassem nas prateleiras das drogarias do Rio de Janeiro, aceitei o desafio, bem sabendo que ia me por em contato com grupos de importância social, mas sem a aceitação do que lhes pudesse causar prejuízo. Convidei Aida Hasson e Lauro Sollero para me ajudar na tarefa. Aceito o convite, iniciamos com experimentos em um cavalo cedido por Paula Machado. Decidi, de imediato, que em vez de pesquisar produtos anormais na saliva, que é um mau concentrador de produtos eliminados, utilizaria, para isso, a urina. Na determinação da existência ou não de fármacos neste humor, utilizou-se a cromatografia em papel. Para minha surpresa, e examinando-se somente a urina do primeiro colocado em cada páreo e de um outro animal sorteado, foram doze os casos de doping que encontramos no primeiro mês de exames. Um dos primeiros animais dopados era de propriedade de uma figura do mais alto padrão econômico. Não satisfeito com os resultados, resolveu aliciar jornalistas especializados que, durante vários meses, publicaram um artiguete contra mim - cientista tupiniquim - no Diário da Noite. Chegou esse proprietário amuado, até mesmo, a instalar um laboratório para o qual chamou um professor assistente da Faculdade de Farmácia de Paris, a fim de demonstrar o erro do método que empregávamos. Essa viagem não chegou a se realizar graças à intervenção do diretor daquela faculdade, professor René Fabre, que mostrou ao jovem assistente a exatidão e as vantagens do método utilizado no Rio de Janeiro. 
A polêmica exauriu-se quando um grupo de bioquímicos ligados ao turfe, na Flórida, aqui veio, por conta própria, e considerou que o método empregado era mais do que válido.

Mais recentemente, o instituto enriqueceu-se com a integração, ao seu quadro, do professor Edson Xavier de Albuquerque, o qual tem estudado, cuidadosamente, a comunicação intercelular, para isso usando técnicas extremamente avançadas. Entre outros resultados, assinalo o estudo do mecanismo de ação de metais pesados na comunicação interneuronal.

As técnicas modernas foram sendo introduzidas, pouco a pouco, na rotina do instituto, quando do retorno do exterior de muitos dos nossos pesquisadores, onde se haviam familiarizado com as mesmas. Assim, por exemplo, a técnica de estudo de comunicação intercelular trazida por um de nossos mais antigos investigadores, Gilberto de Oliveira Castro, depois de sua permanência nos Estados Unidos.

Outra atividade do instituto resultou da minha participação no United Nations Scientific Committee on the Effects of Atomic Radiation, organizado pelas Nações Unidas por solicitação do governo da Índia, tendo em vista as explosões de Hiroshima e Nagasaki, e os testes com bombas de hidrogênio na estratosfera, realizados pelos Estados Unidos e pela URSS. Um dos aspectos do efeito das ações ionizantes estudado foi a frequiência de alterações cromossômicas em pilotos de vôos supersônicos, o que também acontece nos sobreviventes do massacre de Hiroshima e Nagasaki. Indicou-se, também, a importância que teria o conhecimento da reação cromossômica às radiações que se observam nas regiões ricas em materiais naturalmente radioativos. $\mathrm{O}$ governo da Índia iniciou vasto inquérito sobre a situação dos habitantes do Kerala, onde se encontra população numerosa vivendo sobre terras de alta atividade radioativa natural. As zonas de areias monazíticas do litoral do Espírito Santo foram, também, apontadas como fontes de estudo desse interessante aspecto da ecologia. Decidi então criar uma missão de estudos em Guarapari, chefiada por Eduardo Penna Franca. Essa tarefa foi precedida de vários seminários preparatórios, organizados por Crodowaldo Pavan, A. Cordeiro e Merril Eisenbud, da Universidade de Nova York. Da apresentação feita, verificou-se, também, a necessidade, para acompanhamento do início dos trabalhos feitos nas zonas de areias monazíticas, de uma unidade de genética humana, à qual se ligariam os trabalhos sobre o desenvolvimento de larvas 
de Rhynchosciara americana, realizados, então, por Maury Miranda. Para chefiar a unidade de genética foi convidado, como já disse, José Carlos Cabral de Almeida, que se tornou, em pouco tempo, um geneticista humano de grande realce. Estudos de campo mostraram, na região de Guarapari, um incremento estatisticamente significativo de modificações cromossômicas. Entretanto, a relativa escassez populacional efetiva, na época, e a ausência de um registro confiável das características mórbidas da população, uma população variável, pois que o sítio era, essencialmente, uma estação de vilegiatura, tornaram impossível obter uma avaliação correta dos efeitos somáticos dessa radiação natural. O mesmo estudo realizou-se na Índia, na China e em outros países com radioatividade natural elevada.

Na mesma ocasião, organizei, no nosso instituto, cursos sobre a aplicação de radioisótopos em biologia e medicina. $\mathrm{O}$ primeiro deles contou com a colaboração do professor J.D. Cooper e, posteriormente, foi administrado por Eduardo Penna Franca. Esses cursos contaram com a participação de estudantes de todo o Brasil, da América Latina, de Portugal e de Moçambique. Ao mesmo tempo, propus que o Hospital dos Servidores do Estado criasse o cargo de "fisico-hospitalar", sendo que, para o mesmo, foi aproveitado Joaquim Pedro de Andrade, que fora aluno do primeiro curso de medicina nuclear.

Firmino Torres de Castro veio do Instituto Oswaldo Cruz, tendo começado a colaborar com pesquisadores do Instituto de Biofisica em 1955 e, finalmente, depois de sua passagem do Ministério da Saúde para o da Educação, ingressou definitivamente em nossos quadros, em 1971. Com sua mulher Jacy Faro de Castro - também pesquisadora do Instituto de Biofisica -, deu início à série de trabalhos sobre bioquímica de eucariotos, particularmente de tripanossomídios, trabalhando principalmente com o Trypanosoma cruzi. Sua larga erudição e grande compreensão humana tornaram-no, rapidamente, um líder. Firmino Torres de Castro é um pesquisador de grande visão no âmbito da biologia de microorganismos vista através das técnicas e dos conceitos que caracterizam a biologia molecular.

No período inicial da vida do Instituto de Biofisica, afastei-me de sua direção quando fui eleito diretor da Faculdade de Medicina, cargo que aceitei embora sabendo das imensas dificuldades e da multiplicidade de preocupações que o mesmo comportava. Sentia que o instituto já havia adquirido vida própria, e a ação do diretor havia sido facilitada pela maturidade de 
Manoel da Frota Moreira e de meus primeiros companheiros no Instituto de Biofísica.

Manoel da Frota Moreira, esplêndido administrador, muito preciso e vigoroso na defesa dos seus pontos de vista, inicialmente serviu à instituição como monitor. Logo depois de graduado em medicina, foi passar dois anos na Universidade de Harvard trabalhando em um de seus departamentos mais respeitáveis. Tornou-se, assim, um especialista em análise de gases no sangue. Mas a sua característica principal era o seu apego ao instituto. Pouco a pouco foi sendo forçado a se distanciar da pesquisa de laboratório, tendo sido solicitado a participar do grupo diretor do CNPq. Seu conhecimento da ciência brasileira e de nossos problemas tornou-o interlocutor indispensável daqueles que adquiriram responsabilidade na administração científica do Brasil. Por suas excepcionais qualidades, Frota Moreira, na sua condição de diretorexecutivo, deu o encaminhamento necessário para que a Fundação Universitária José Bonifácio pudesse prestar à Universidade Federal do Rio de Janeiro uma extraordinária contribuição. Manoel da Frota Moreira fez parte do grupo inicial do Instituto de Biofísica, junto com Tito Enéas Leme Lopes.

Tito Enéas Leme Lopes era inspetor de leite em Guaratinguetá quando, aprovado em concurso, eu o chamei para assistente, conforme já relatei. Escolha feliz pela soma de contribuições por ele dada ao crescimento de nossas atividades. Intelectual de capacidade invulgar, leitor insaciável de livros científicos e literários, era um didata de surpreendente exuberância. A essas qualidades aliava-se uma atitude franca perante a vida e um riso contagiante. Predominava em sua personalidade, entretanto, uma intensa curiosidade que, ao mesmo tempo que lhe dava uma cultura extensíssima, tirava-lhe a concentração indispensável a um pesquisador, que, para realizar a sua tarefa, precisa ter uma linearidade de objetivos que o leva à resposta da questão formulada no planejamento de seu projeto de pesquisa.

A José Moura Gonçalves coube a formação técnica de grande parte dos jovens estudantes que procuraram o instituto. Tendo participado do Congresso de Bioquímica, em Estocolmo, permaneceu durante algum tempo nos Estados Unidos, no National Institutes of Health, com Jesse Greenstein, de onde trouxe para o nosso campo de trabalho a cromatografia em papel. Essa técnica foi, logo de saída, de extrema utilidade na determinação de alguns elementos bioquímicos do órgão elétrico. De muita competência no 
setor teórico e na realização experimental, coube a Moura Gonçalves instalar o aparelho de eletroforese livre ou eletroforese de fronteira móvel (métodos descritos por A. Tiselius) e, dentre suas várias contribuições, cite-se a determinação dos componentes proteicos do veneno crotálico. Estudando venenos de cobras de vários pontos do país, mostrou que existem entre os mesmos diferenças na composição proteica dos seus venenos, embora as espécies morfologicamente sejam as mesmas, obtendo, assim, uma prova bioquímica de diferenças específicas conseqüentes a prováveis modificações ambientais. A eletroforese livre foi uma das várias técnicas postas em uso contínuo no instituto e a microscopia eletrônica outra delas.

Com o crescimento da utilização do microscópio eletrônico em biologia, tornou-se uma necessidade a sua integração aos trabalhos realizados no Instituto de Biofísica. Alguns anos depois de terminada a guerra, a General Electric apresentou ao público de São Paulo e do Rio o seu microscópio de mesa. Vários foram vendidos em condições muito favoráveis, nas duas cidades. $\mathrm{O}$ representante daquela companhia foi procurar-me, oferecendo ao instituto condições excepcionais de compra. Recusei o pedido, porque o microscópio de voltagem fixa não serviria às nossas finalidades. Resolvi então organizar um curso sobre "microscopia eletrônica aplicada à biologia", que ficou sob a responsabilidade de Keith Porter, o qual convidou para participar do ensino Hernandez-Morán, especialista venezuelano então terminando o seu estágio em Estocolmo e, logo a seguir, fundador do Instituto Venezolano de Investigaciones Científicas (Ivic), construido com os maiores detalhes estruturais, em Caracas.

Os integrantes brasileiros orientadores do curso foram Hertha Meyer, do Instituto de Biofisica, e Raul Dodsworth Machado, do Instituto de Óleos do Ministério da Agricultura e grande especialista em óptica instrumental, como já dito, que mais tarde veio a se integrar ao nosso instituto. Em tratativas com a companhia Philips, consegui preço excepcional e, também, o estágio de Hertha Meyer nos laboratórios de Eindhoven, tendo seguido, mais tarde, para os Estados Unidos, onde percorreu várias unidades de eletromicroscopia. Também o técnico Fernando Barbosa Hargreaves, irmão do pesquisador Alberto Hargreaves, visitou esses laboratónios dos Estados Unidos.

Outra técnica que se desenvolveu com rapidez, no instituto, foi a da utilização de circuitos de ampliação eletrônica para a determinação de 
potenciais de ação ou qualquer outra atividade elétrica celular. A primeira instalação, em 1939, foi feita da maneira seguinte: havia eu voltado da Europa, onde freqüentara, principalmente, o laboratório do Instituto Marey, na França, no qual trabalhavam Alfred e Denise Fessard, e, posteriormente, na Inglaterra, no Departamento de Fisiologia da Universidade de Cambridge, em período de curta duração. Esses dois estágios permitiram-me conhecer as técnicas empregadas por E. Adrian, que utilizava, ainda, um galvanômetro de oscilação mecânica, e Brian Mathews, A. Huxley e Richard Keynes, que empregavam, para a análise dos potenciais obtidos, o oscilógrafo de raios catódicos. Resolvi construir, subsidiado por Guilherme Guinle, um aparelho destinado ao registro de potenciais de ação de nervos periféricos. Despreparado eu mesmo, procurei saber, de casa em casa, quem seria capaz de fazê-lo. Qual não foi o meu espanto quando os mais bem informados indicaram-me um mesmo nome, Gustavo Corção, que mais tarde atingiria a fama como escritor, pensador chestertoniano, e católico muito polemizado pelos “donos da verdade". Na ocasião, Corção trabalhava na firma Corção, Cardim \& Cia., de seu irmão, num grande galpão na rua do Lavradio, e, três vezes por semana, lecionava pelas manhãs, no Instituto Militar de Engenharia. Nessas manhãs, terminada a sua tarefa, vinha ele ao nosso laboratório para conversar e discutir, em primeiro lugar, os problemas criados por minha encomenda e, logo depois, questões de religião, filosofia e política, nas quais a força de sua argumentação, antigo membro do "Partidão" que fora, muitas vezes me deixava atônito. Como eram agradáveis essas manhãs, continuadas depois por um duradouro almoço num pequeno restaurante da avenida Mem de Sá, onde se concluía o debate que recomeçaria nos almoços subseqüentes. Uma vez, indo da Praia Vermelha para a cidade, uma obstrução no asfalto fez com que meu velho Ford jogasse mais do que o habitual. Em conseqüência, saltou do porta-luvas meu livro de missa. Corção abaixou-se para pegá-lo e, pouco adiante, perguntou-me se eu era católico. À minha afirmativa, disseme ele que estava a caminho da franca conversão. Nesse dia, a conversa ao almoço versou problemas de religião. Em certo momento, verifiquei que a minha pequena formação católica não podia dialogar com a forte curiosidade intelectual de Corção. Disse-lhe que ele precisava conhecer um amigo, líder da mocidade católica, Alceu de Amoroso Lima. A aceitação de Corção levou-me ao telefone e fez com que Alceu marcasse um encontro com o 
meu amigo para almoçarem no Restaurante do Lido. Alguns dias depois, encontrei-me com Corção e por ele soube que o encontro havia sido, na verdade, um desencontro total de idéias. Alguns anos mais tarde, eu os vi na porta da Livraria Garnier, em plena confraternização. Creio que a reconciliação foi feita por intermédio dos monges do Mosteiro de São Bento, cuja missa dominical era do hábito de Alceu e começara a ser freqüentada por Corção. O relacionamento de Corção com a Igreja fizera-se anteriormente. Havia ele sido encarregado de receber o "sinal eletromagnético" vindo do Vaticano para iluminar a recém-inaugurada estátua do Cristo Redentor, no Corcovado. Diz-se que na hora aprazada os emissores do Vaticano não chegaram à estação de recepção, no Rio. Corção decidiu, por si mesmo, iluminar o Cristo no momento esperado.

A vida no instituto continuou em plena ascensão e raras eram as semanas em que não iam me ver rapazes e moças, em geral estudantes de medicina, que desejavam trabalhar em ciência. Aprovados em entrevista comigo, encaminhava-os a um dos pesquisadores para aprenderem as técnicas habituais do laboratório. Isto garantia um primeiro aprendizado do método quantitativo, o qual era seguido de um pequeno trabalho de laboratório. Não posso dizer do número de jovens que foram nos procurar. Muitos, dentre eles, tornaram-se, depois do estágio no Instituto de Biofisica, excelentes profissionais.

Continuei, também, a realizar colóquios, seja para conhecimento de técnica, seja para a abertura de novas estradas de conhecimento. Tendo, em uma das minhas viagens, tomado ciência de novos métodos da microscopia óptica, organizei um colóquio de uma semana sobre microscopia, estrutura celular e novos métodos. Entre os convidados, contei com a presença de HernandezMorán, Frey-Wissing e Maurice Wilkins, a quem foi outorgado, posteriormente, o Prêmio Nobel, conjuntamente com Watson e Crick, sobre seus trabalhos relativos à estrutura cristalográfica do ácido nucleico.

Para comemorar o $25^{\circ}$ aniversário do instituto, em 1962, organizei, sob os auspícios da Unesco, uma reunião sobre "perspectivas da biofísica", que contou com a presença de Severo Ochoa, Daniel e Filomena Bovet-Nitti, M. Florkin e John Eccles. Essas reuniões, que contavam sempre com a presença de cientistas mais ou menos jovens de todo o Brasil, serviam não só para ilustrar o conhecimento dos meus companheiros de trabalho como, 
ainda, para fazê-los conhecer pessoalmente cientistas com os quais poderiam, posteriormente, realizar estágios de graduação ou doutoramento.

Um colóquio sobre mecanismos de curarização, realizado com a participação do Museu Nacional, veio logo a seguir. Foi essa instituição que deu início às pesquisas levadas avante, no Brasil, sobre os curares. Nelas trabalharam Louis Couty e João Batista de Lacerda, o qual, com a sua contribuição sobre a propriedade curarizante de uma única substância, a delta-tubocurarina, retirada do Strichnus triplinervis, acabou com a proposição de A. von Humboldt de que seriam necessários, de conformidade com os procedimentos indianos, extratos de pelo menos duas plantas amazônicas para a produção de um verdadeiro curare. A linha iniciada por Batista de Lacerda tornou possível a análise elementar de um curare, obtida por Paulo Carneiro nos laboratórios de Gabriel Bertrand, no Instituto Pasteur de Paris. Nesse colóquio tomou parte, também, Darcy Ribeiro, que apresentou o seu admirável livro $A$ arte plumária dos índios da Amazônia, recebido com a maior admiração pelos vários antropólogos presentes.

Uma das reuniões mais bem-sucedidas realizou-se como simpósio satélite da V Conferência Internacional de Fisiologia, que teve lugar em Buenos Aires, em 1939. O simpósio, organizado pelo instituto, versou sobre a "bioeletrogênese", nele tendo sido apresentados os trabalhos feitos no instituto sobre a produção de eletricidade pelo Electrophorus electricus (L.) e os mecanismos de curarização do órgão elétrico dessa mesma espécie animal, e contou com a presença dos melhores especialistas do momento. Citem-se, dentre eles, David Nachmanson, John Eccles e Richard Keynes. Todos os trabalhos do simpósio foram publicados em forma de livro pela Editora Elsevier e apresentaram à comunidade internacional atividades realizadas em nosso país e até então mal apreciadas.

Nessa linha de realizações devem ser assinalados o já citado colóquio sobre a tireóide, organizado por Luiz Carlos Lobo, e um outro, que teve a finalidade de fornecer à comunidade científica do país dados importantes sobre o progresso que se desenrolava no domínio da microscopia óptica. Nesta, as lentes habituais nos microscópios são substituídas por espelhos refletores, donde a denominação, também usada, de "microscopia de reflexão". Do instituto tomou parte, com o brilho de sempre, Raul Dodsworth Machado.

A atividade do instituto no terreno da pesquisa continuou a se desenvolver, e o número de jovens que o procuravam, na Praia Vermelha, crescia de ano 
para ano, muito embora o Instituto de Biofisica não estivesse em condições de receber todos os que desejavam dar início à sua formação científica. Esse interesse pelo instituto justificava-se, a meu ver, por sua localização na Praia Vermelha, onde parte do curso básico de medicina era dado, e, ainda, pela vizinhança da Faculdade de Farmácia e da Escola de Química. Junte-se a este, o fato de que a população de cientistas que se formava no Instituto de Biofisica era bastante moça, e, assim, mais próxima desses mesmos jovens.

O corpo de pesquisadores/docentes cresceu sensivelmente nestes últimos anos, pois a universidade enfim compreendeu não ser necessária a existência de uma vaga para a obtenção da titularidade, mas simplesmente disposição interna que permita a sua criação e seu preenchimento, mediante concurso, por especialistas, muitos dos quais vindos de outras universidades ou centros de pesquisa. Em conseqüência, o número de nossos pesquisadores docentes passou de quatro para cinqüienta e quatro, em cinqüenta anos, todos eles realizando pesquisas e atividades docentes no nível de graduação e pósgraduação. Até dezembro de 1997, o nosso quadro de docentes permaneceu dentro dos valores históricos dos últimos quinze anos, vale dizer, de oitenta e cinco a noventa. Repete-se, assim, o que é norma nas universidades de grande qualificação intelectual.

As principais atividades de pesquisa continuaram centralizadas na bioeletrogênese do órgão elétrico, na depressão alastrante, na interação de parasitos com células em cultura, ao mesmo tempo que se desenvolviam estudos sobre enzimas e a histoquímica passou a ter uma participação destacada nos trabalhos realizados. 



\section{VI}

\section{Direşão da Faculdade de Medicina}

$\mathrm{N}$

a década de sessenta fui obrigado a dar uma descontinuidade, ainda que pouco acentuada, à minha atividade de diretor do Instituto de Biofísica. É que a congregação da Faculdade de Medicina resolveu propor meu nome para diretor da mesma, como disse anteriormente. Aceito pelo presidente João Goulart poucos dias antes de sua deposição pela revolução vitoriosa de 1964, solicitei, em conseqüência, uma nova votação que, mais uma vez, me colocou em primeiro lugar na lista tríplice. Confirmada minha nomeação pelo presidente Castello Branco, assumi o posto com a expectativa de poder trazer sensíveis modificações ao funcionamento da velha instituição. Já em direções anteriores, particularmente por ocasião da direção de Fróes da Fonseca, procurara eu mexer um pouco em algumas das antigas normas da casa. Consegui, então, que a biblioteca da faculdade, extremamente rica no período de sua fundação até a década de vinte, fosse transferida para a Praia Vermelha. Fróes da Fonseca fez erigir mais um andar, para o qual foram transferidos os livros mal guardados e cheios de umidade, depositados no Instituto Anatômico, na rua Santa Luzia. Nessa tarefa fui auxiliado pela extraordinária competência de Emília Bustamante, que, na ocasião, trabalhava na biblioteca do Instituto Oswaldo Cruz, cujo diretor permitiu o seu longo estágio na Praia Vermelha. Tive, ainda, o auxílio do bibliotecário Mário Filho, também de Manguinhos.

O problema das bibliotecas é um dos que perturbam, de forma mais aguda, a vida de uma instituição científica no Brasil. Orçamentos pobres, as 
mais das vezes retardados, impedem a pronta assinatura de publicações que, no correr deste século, tornaram-se, no campo das ciências, o verdadeiro âmago de uma biblioteca científica. Quando mais tarde vim a ser decano do Centro de Ciências da Saúde da universidade, procurei dar todo o apoio à Biblioteca Central daquele centro, instalado na Ilha do Fundão desde 1972. Tarefa mais do que dificil, não só pelo preço vertiginoso da assinatura de revistas e dos livros científicos ligados ao crescimento da indústria de publicações, como também pela teimosia de cada chefe de departamento, que desejava ter, para uso exclusivo do seu grupo, um certo número de publicações gerais ou especializadas. Estas deveriam estar presentes em um centro rotativo, do qual participassem todos os interessados em seu próprio aperfeiçoamento intelectual. Para a biblioteca do Centro de Ciências da Saúde obtive verba excepcional, o que a colocou em dia. A condição da Finep - Financiadora de Estudos e Projetos - para a concessão desse auxílio foi a de que a universidade mantivesse a biblioteca funcionando até as vinte horas, inicialmente, e no momento em que o Fundão se tornasse mais freqüentado, até a meianoite. Devo a um amigo, Virgílio Costa, de uma dedicação inigualável, a organização da biblioteca do Centro de Ciências da Saúde.

A primeira tarefa que me coube na direção da Faculdade de Medicina foi a de refazer o regimento intemo, com numerosíssimos artigos, muitos dos quais até mesmo contraditórios. Isto foi feito com uma certa facilidade, dado o apoio que tive dos meus companheiros, entre os quais desejo citar Lauro Sollero, Clementino Fraga Filho e Carlos Cruz Lima. Esse enxugamento do regulamento permitiu-me nomear, como diretores associados, Antônio Paes de Carvalho, para o setor de ensino, e Luiz Carlos Lobo, para o de planejamento.

Coube-me, também, uma tarefa extremamente contundente: a de aplicar um novo parágrafo da reformulação do ensino, o qual determinava que os professores com mais de sessenta anos deveriam ser aposentados, a não ser que dois terços dos professores titulares os mantivessem na função. Sabia eu que algumas das faculdades da universidade haviam tentado pôr esse artigo em prática. Nelas, a votação de cada caso em separado fora substituída pela votação maciça de uma lista que incluía todos aqueles atingidos pelo novo regulamento. Telefonei para Raimundo Moniz de Aragão, então ministro da Educação, perguntando se o artigo deveria ser cumprido ou esquecido. 
A reação do ministro foi positiva, isto é, o regulamento era para ser cumprido. Isto me dava suporte para uma eventual disputa sobre a questão. Assim sendo, convoquei a congregação para uma sessão especial, tendo como assunto único na pauta a votação da solicitação de aposentadoria para quatro professores que haviam atingido a idade limite. A congregação eliminou dois dos professores citados. Com o maior constrangimento aceitei a votação, que eliminava do nosso convívio o irmão de um amigo fraterno e um dos grandes pesquisadores da casa, famoso por seus trabalhos sobre endocrinologia.

A atividade na direção da Faculdade de Medicina correu sem grandes percalços. Tive sorte, porque foi um período em que os estudantes estavam muito calmos e várias vezes mantive, com seus líderes, entendimentos extremamente úteis. Sou dos que pensam que o desassossego dos alunos resultava do desencontro entre ao que, na sua juventude, aspiravam da faculdade, $e$ as reais condições de ensino que esta podia oferecer. $\mathrm{Na}$ ocasião, por exemplo, o curso clínico-médico-cirúrgico estava distribuído entre seis hospitais do Rio de Janeiro, obrigando o aluno a se locomover de lá para cá, em uma cidade de transporte precário. Assim, procurei dar às clínicas o maior apoio.

Quase no fim do meu mandato tomei uma iniciativa que me pareceu ser de extrema utilidade. É que se tentava acabar a construção do Hospital das Clínicas, na llha do Fundão. Fui, então, ao prefeito do Rio de Janeiro, Francisco Negrão de Lima, e solicitei-lhe que pusesse à disposição da faculdade o Hospital Moncorvo Filho. Seria ele o centro de preparação operacional do novo e grande hospital, incluindo-se nessa proposta, principalmente, o treinamento de pessoal auxiliar. Negrão de Lima acedeu de imediato ao meu pedido, mesmo porque vários dos nossos serviços hospitalares já estavam sendo feitos no Moncorvo Filho.

Outra iniciativa que tomei foi a de solicitar a transferência do escritório chefe das obras do hospital do Fundão para a sede da faculdade. A medida teve grande êxito, pois facilitou o intercâmbio entre os nossos professores e os engenheiros do chamado Etub (Escritório Técnico da Universidade do Brasil), localizado numa das alas do Ministério da Fazenda, no Centro, ocupada pelo Dasp.

Tentei, em vão, demover Pedro Calmon e seus assessores de transferir a universidade para a Iha do Fundão. Várias razões me levaram a isto. Em primeiro lugar, a dificuldade de condução para alunos e mestres, principalmente para 
aqueles. A idéia falaciosa de que o Fundão correspondia ao centro geométrico da cidade, que punha os alunos da região norte e os alunos da região sul aproximadamente eqüidistantes do centro da universidade, não me parecia válida. Além do mais, a mudança para o Fundão não era, de modo algum, a meu ver, o mecanismo mais fácil e eficaz para estabelecer traços de ligação espiritual e material entre as várias unidades da universidade, mesmo porque as distâncias existentes na ilha criada, ou quase criada, no fundo da baía, eram grandes. Quando eu trabalhava na Praia Vermelha, a Escola de Química, por exemplo, estava muito mais próxima do que a distância que a separa do Instituto de Biofisica, hoje, no Fundão.

Algum tempo mais tarde, pretendi implantar na Ilha o Dia da Árvore, para o que obtive dezoito mil pequenos arbustos doados pelo professor Marques Porto, diretor do Jardim Botânico, e que deveriam ser plantados pelos próprios alunos, no dia dedicado à árvore, 19 de novembro. Infelizmente, parte da alta direção da instituição não se interessou pelo projeto, que teria dado uma nova e encantadora feição ao árido terreno que a universidade ocupava.

Nesse período em que fui diretor da faculdade (1964-1966), na Praia Vermelha, e no qual recebi a melhor solidariedade de meus colegas, uma das minhas iniciativas foi a de abrigar, no restaurante desativado, todos aqueles que haviam perdido suas casas e seus pertences, em conseqüência dos terríveis temporais que desabaram sobre o Rio de Janeiro, em 1966. Contei com a ajuda de minha mulher, que, com muita acuidade, solicitou o apoio dos militares da Escola Superior de Guerra, os quais deram uma estrutura perfeita àqueles que se alimentavam e dormiam no local improvisado. Uma impressão que guardo dessa época é a solidariedade da sociedade, face a um cataclismo como aquele que estávamos sofrendo. Bastou um pequeno apelo nos jornais para que nos chegassem toneladas de alimentos, o que permitiu o serviço de alimentação e proteção contra a intempérie aos mais de duzentos desabrigados então socorridos.

Outra iniciativa que tomei foi a da criação de um vestibular único para estudantes das faculdades de medicina da cidade do Rio de Janeiro. Contei, para isso, com a colaboração de Luiz Carlos Lobo

e a compreensão de Américo Piquet Carneiro, diretor da Faculdade da Universidade do Estado do Rio de Janeiro, Uerj, e do general-médico, 
doutor Meirelles, diretor da Faculdade Hanemaniana, hoje incorporada à UniRio. Foi um empreendimento cheio de riscos, que não podia falhar. Pedro Calmon emprestou-me um vasto edificio onde havia sido instalada a tipografia da universidade, situado ao lado da sede da mesma, na avenida Pasteur, e que se encontrava desocupado. Ajudou-me de maneira particularmente elogiosa um dos funcionários da faculdade, Michel Jourdan. Felizmente, tudo correu às maravilhas, sem nenhuma reclamação. Serviu essa iniciativa, provavelmente, como exemplo para a criação, em proporções muito mais largas, do Cesgranrio.

Mais uma iniciativa que considero importante nasceu da concepção que partilho com um sem-número de colegas e amigos, de que há, na formação de algumas doenças, um componente ligado às condições de vida e de família do paciente. Para isso, fiz um projeto de levar os alunos do segundo ano de medicina a conhecer a vida familiar dos habitantes do Rio. Escolhi, para tanto, a Ilha do Governador e, para dirigir o projeto, o professor Roberto Santos, da Bahia, que se interessou pela iniciativa. Obtive, também, para realizá-la, um auxílio do Instituto de Pesquisa Econômica Aplicada (Ipea). Com seus dirigentes discuti o projeto, considerado por alguns dos conselheiros como "comunizante". Durante todo o ano funcionou perfeitamente, com grupos de dez alunos acompanhados de um assistente visitando famílias da Ilha. Infelizmente, o projeto não teve continuidade depois que deixei a direção da faculdade. Devo dizer, aliás, que inicialmente alguns alunos não o apreciaram devidamente, mas, aos poucos, foram se adaptando à idéia, até chegar ao ponto de me congratularem por ele. 



\section{VII}

\section{Ciência e cultura: criação do CNPq, Conferências das Nações Unidas $e$ Embaixada do Brasil na Unesco}

nvolvi-me muito, e durante longos anos, com o que foi, sem dúvida, a Nacional de Pesquisa, uma velha aspiração da comunidade científica, foi um processo longo, que penso ter tido início numa série de reuniões que Paulo Assis Ribeiro realizou na primeira sede da Fundação Getúlio Vargas, na Praia de Botafogo. Ali juntaram-se cientistas mais idosos e mais moços, que discutiram, com bastante interesse, a organização científica do Brasil. Eu já me havia interessado pelo assunto, quando da minha viagem à Europa. René Wurmser me havia dito como a ciência francesa havia tomado um novo impulso com a criação, por Jean Pérrin, do Centre National de la Recherche Scientifique (CNRS), no momento em que a Frente Popular havia tomado o governo com a vitória da esquerda nas eleições. Wurmser se ofereceu para que eu tivesse uma entrevista com Jean Pérrin. Fui por este recebido com a maior afabilidade, mesmo porque havia ele visitado o Brasil e se tornara amigo dos Ozorio de Almeida.

Era Pérrin um homem de estatura baixa, encimado o corpo bastante forte por uma linda cabeça onde sobressaíam dois olhos maravilhosos, desta cor azul que só se encontra em alguns seres da humanidade. Com a maior gentileza explicou-me o que era o CNRS e como havia sido criado, dando-me todo o material disponível, referente à sua criação, para que eu o trouxesse para o Brasil. Foi o que fiz, entregando-o ao ministro Gustavo Capanema, que mostrou-se entusiasmado com a idéia e levou esse material ao presidente 
Getúlio Vargas. Na ocasião, escrevi um pequeno trabalho sobre o CNRS, que passou despercebido, embora publicado pela Seção de Intercâmbio Internacional do Ministério das Relações Exteriores, dirigida pelo ministro Temistocles da Graça Aranha.

Faltava, entretanto, para dar maior peso ao movimento, uma personalidade de alto calibre. Surgiu ela na pessoa do almirante Álvaro Alberto da Motta e Silva. Álvaro Alberto era uma personalidade de elevada qualidade intelectual e formação técnica. Professor na Escola Naval, a excelência de seus estudos sobre explosivos dera-lhe grande proeminência na comunidade de defesa. Acabara de exercer função importante nas Nações Unidas, função na qual coube-lhe a presidência da Primeira Conferência sobre Energia Nuclear, realizada em Nova York. Presidiu-a com a eficiência que o caracterizava, e voltou dos Estados Unidos com dois objetivos indispensáveis ao desenvolvimento nacional: o da criação de uma organização para gerir a pesquisa científica e tecnológica em nosso país e, ainda, o de dar o seu empenho para que o Brasil, rico em minerais uraníferos e em areias monazíticas, desenvolvesse um projeto nuclear. Seu prestígio pessoal, não só nas Forças Armadas, como também na comunidade científica, que não podia deixar de admirar o seu trabalho na incipiente Academia Brasileira de Ciências, seja como seu membro ativo, seja como seu presidente, tornou possível a criação do Conselho Nacional de Pesquisas (lei 1.310, de 15/10/1951), mais tarde transformado em Conselho Nacional de Desenvolvimento Científico e Tecnológico (lei 6.129, de 6/11/1974) e, dentro deste, de uma comissão de energia atômica que daria origem, mais tarde, ao Conselho Nacional de Energia Nuclear.

$\mathrm{Na}$ ocasião em que se criou o CNPq, estava eu em Paris ministrando um curso sobre "a aplicação de métodos radioativos à histologia", para o qual fora convidado por A. Monier, da chamada Sorbonne, quando Costa Ribeiro telefonou-me para dizer que eu deveria solicitar a Afonso Arinos, meu cunhado, seu empenho para que eu fosse incluído no Conselho Deliberativo do órgão recém-criado. Respondi-lhe que não faria o pedido, o que aconteceu. Ao chegar ao Rio, algum tempo depois, Álvaro Alberto telefonou-me com a sua habitual gentileza, dizendo-me que, infelizmente, não pudera me colocar no conselho, mas que fazia questão da minha colaboração e que me pedia para aceitar a posição de chefe do Setor de Pesquisas Biológicas, 
dentro da Divisão Técnico-científica que seria dirigida por Costa Ribeiro. Foi assim que comecei minhas atividades no conselho, fazendo Álvaro Alberto questão de que eu participasse sem voto, mas com voz ativa, nas reuniões mensais do mesmo.

Dirigindo o Conselho do CNPq, Álvaro Alberto podia estender o horário de trabalho até altas horas da noite, sem mostrar a menor fadiga. Eram verdadeiras reuniões de trabalho, as quais, iniciadas às quatro horas da tarde, nunca terminavam antes das onze horas da noite. Muitas vezes saíam estafados das reuniões, como eu mesmo, os conselheiros, muito mais moços do que ele. A essas reuniões, Álvaro Alberto trazia ao nosso conhecimento todos os projetos apresentados ao conselho e, com a maior simplicidade, discutia conosco as decisões que desejava tomar, bem como as orientações que pensava seguir. Memória prodigiosa o ajudava a discernir, com a maior lucidez, as dificeis questões que se apresentavam. Tinha Álvaro Alberto o poder de contemporizar, no melhor sentido, as forças antagônicas aos projetos do conselho, que se batiam, muitas vezes, com desconhecimento real. Sua exemplar honestidade completava o quadro de um varão de probidade por todos reconhecida.

A atividade no conselho era extremamente agradável. Seu corpo administrativo havia sido escolhido com muito cuidado pelo almirante e, diariamente, por assim dizer, tínhamos contato com os pesquisadores que para lá se dirigiam a fim de levar os seus progressos ou discuti-los. Eu fazia parte do grupo de direção científica, comandado pelo admirável Joaquim da Costa Ribeiro, acompanhado de assistentes da melhor qualidade. Para me auxiliar na tarefa de encarregado do Setor de Biologia convidei Antônio Moreira Couceiro, que mais tarde veio a ser presidente do conselho, e Gustavo de Oliveira Castro. Meus contatos com Costa Ribeiro, então diretor do Departamento Científico, eram bem antigos. Vários fatores haviam facilitado a nossa amizade, inclusive as boas relações de meu pai com a família dele. Além do mais, Costa Ribeiro tinha se juntado a Oliveira Castro e a Carneiro Felippe, no esforço de me ajudar na preparação do meu concurso para a faculdade. Passei horas em sua companhia, no laboratório da Escola Politécnica, localizada, então, no Largo de São Francisco, preparando a parte prática da prova a que iria me submeter. Tal convivência levou-me à intimidade da família e coube-me ver crescer seus nove filhos. Um deles, Carlos, tornou-se mais tarde, por concurso, 
professor-adjunto do Instituto de Biofisica. Os momentos que passei em contato com a família de Joaquim da Costa Ribeiro marcaram profundamente a minha alma.

Formou-se, entre o almirante e eu, nessa ocasião, uma intimidade de pensamento que me permitiu, muitas vezes, influenciá-lo, tendo em vista a minha experiência na direção científica de um laboratório e o conhecimento que apreendera, tanto no Conselho Nacional de Pesquisas Científicas, francês, como nos Conselhos Setoriais que J.B. Haldane estabelecera na Inglaterra, logo depois do término da Primeira Guerra Mundial. Defendi, junto a Álvaro Alberto, uma relação íntima do pesquisador com o conselho, caracterizada pelo fato de que aquele se dirigia diretamente a nós, conselho, sem a anuência do chefe da instituição a que pertencesse. Essa norma foi mantida durante muito tempo, até mesmo contra a vontade de um dos diretores do Instituto Oswaldo Cruz. Limitei, o mais possível, a concessão de auxílios a grupos médicos amparados por fortes forças políticas, mas sem trabalho científico que justificasse o auxílio. Procurei conhecer de perto pesquisadores e instituições solicitadoras de auxílios, tendo várias vezes viajado para melhor conhecer o desenvolvimento da pesquisa científica no país.

Consegui, sem dificuldades, que Álvaro Alberto criasse as bolsas de complementação correspondentes, na verdade, ao tempo integral. Procurei incentivar as pesquisas de interesse biológico relacionadas, principalmente, com o conhecimento e a proteção do meio ambiente. Quero dizer que os anos que vivi no Conselho Nacional de Pesquisas foram, para mim, admiráveis, não só aqueles em que exerci atividades de diretor do Setor de Biologia, como também nos que passei como membro do Conselho Deliberativo. A começar pela cordialidade e capacidade de direção de Álvaro Alberto, que eu considero um dos personagens de melhor valia que conheci na minha vida, até os funcionários mais ou menos graduados e, também, os membros do Conselho Deliberativo, todos davam ao trabalho uma expressão de dedicação e patriotismo, o que me fazia acreditar na significação, direi até da importância, para o Brasil, da tarefa que me incumbia. Era o mesmo sentido de progresso e realização que me animava ao trabalho no Instituto de Biofisica.

Entretanto, nunca será suficiente assinalar o que representou, para o progresso do nosso país, a presença de Álvaro Alberto, sem o qual os primeiros 
passos do Conselho Nacional de Pesquisas teriam sido por demais lentos e não teriam tido a eficácia que tiveram.

Ao lado dos pedidos de auxílio que chegavam à nossa sede na avenida Marechal Câmara, resolvi, também, procurar instituições que devessem receber auxílios globais. Uma delas foi o Museu Nacional, que ainda não pudera auferir das vantagens de ter sido integrado à Universidade Federal do Rio de Janeiro. Depois de algumas visitas à instituição, propus que a mesma recebesse um auxílio global que permitisse ao seu diretor o atendimento de certas deficiências e a correção de alguns problemas graves, tais como a conservação do material do Museu de Antropologia. Meu pedido foi aprovado, sem a menor contestação, pelo Conselho Deliberativo.

Durante o período que vai desde a minha integração ao Conselho Nacional de Pesquisas até a ida para a Unesco, tomei parte em várias reuniões de instituições governamentais. A primeira delas foi a participação no Comitê de Estudo da Ação das Radiações Ionizantes, na ONU, que vim a presidir em 1956. O comitê foi organizado logo depois da consternação mundial provocada pelas explosões nucleares, que eliminaram do mapa as cidades japonesas de Hiroshima e Nagasaki, e das primeiras explosões nucleares atmosféricas realizadas pela União Soviética. A nação que pediu a sua criação ao Conselho das Naçôes Unidas foi a Índia. A minha indicação para representar o Brasil foi feita por Marcelo Damy de Souza Santos, então presidente do Conselho Nacional de Pesquisas e, em consequiência, também presidente da Comissão de Energia Atômica, daquele dependente, e da qual eu fazia parte, e que deu origem ao Conselho Nacional de Energia Nuclear.

Inicialmente, a Comissão da ONU foi presidida por um ilustre radiobiologista belga, o professor Zenon Bacq, o qual substituí, depois de dois anos de sua presidência. Era o comitê constituído por quatorze membros, delegados dos países de origem, com alguns dos melhores especialistas em radiobiologia de todo o mundo. Foi o momento em que o perigo das radiações ionizantes alarmou, a meu ver, justamente, o homem da rua. Assinalo, ainda, que uma das causas desse fato foi a posição quase heróica de alguns cientistas norte-americanos, como Linus Pauling, que não escondiam nada à população e, muitas vezes, serviam de publicidade à imprensa menos escrupulosa. Por causa da diferença do fuso horário, várias vezes fui acordado 
muito cedo, para o meu gosto, por jornalistas cariocas que desejavam que eu interpretasse as últimas declarações do grande Pauling.

As sessões eram bianuais e realizavam-se sempre na sede em Nova York. $\mathrm{O}$ trabalho do secretariado era extensíssimo e compreendia todos os aspectos das conseqüências da ação das radiações ionizantes. Nunca poderei enunciar o quanto me foi útil, do ponto de vista científico e técnico, minha passagem por essa comissão. Impressionava-me, também, a preparação dos delegados que vinham às nossas reuniões $\mathrm{e}$, mais particularmente, dos representantes da Rússia e de outros países comunistas, diria eu, quase em oposição à dos países ocidentais, entre os quais sobressaía, sem dúvida, a representação dos Estados Unidos, fortemente apoiada por sua Comissão Nacional de Energia Nuclear.

Colateral ao programa nuclear do qual estávamos tratando, é interessante sublinhar a longa discussão sobre a utilização, em medicina, dos raios X. Um dos episódios mais curiosos da minha passagem pela presidência do comitê foi a reação bem-sucedida que tive que impor contra numerosos documentos, principalmente de origem pan-americana, que solicitavam uma manifestação do comitê contra a utilização dos raios X, para aplicações médicas. Pareceume, a certo momento, que havia uma espécie de frenesi contra as radiações ionizantes e, particularmente, contra a utilização médica dos raios de Roentgen. Assim é que, numa das conferências que se realizaram, periodicamente, no Instituto de Biofísica para estudos de radiações ionizantes, um grande geneticista brasileiro, de temperamento talvez exaltado, declarou que não permitira a utilização dos raios X na ocasião em que um dos seus filhos pequenos sofrera uma fratura no fêmur. Propunha, com ardor, a limitação exígua na utilização de raios $\mathrm{X}$, assunto que saiu da pauta com a intervenção veemente de Crodowaldo Pavan, um dos melhores cientistas brasileiros, especialista em genética.

O que eu aprendi na convivência dos colegas do Comitê de Radiações, inclusive dos delegados da União Soviética, ainda que muito ortodoxos, foi extraordinário e, mais uma vez, mostrou-me a importância que tem, para o desenvolvimento do conhecimento, a sua abordagem horizontal.

Deixei, e direi, com pena, o Comitê de Radiações quando, subitamente, sem ter a mínima noção do que seria, fui designado por U Thant, em 1963 , para secretário-geral da Conferência das Nações Unidas para a Aplicação da Ciência e da Tecnologia ao Desenvolvimento. Creio que essa experiência 
internacional, vivida com paixão, é que levou Henri Laugier, que bem conhecia o Brasil, onde estivera a convite dos irmãos Ozorio de Almeida, a indicar o meu nome. Essa proposição foi aceita pela comissão encarregada do esboço geral do programa, que rejeitou a proposta brasileira de ser nomeado, para tal posto, um dos nossos economistas de escol.

A indicação, da qual não tinha o menor conhecimento, nem mesmo da existência da conferência, pegou-me de surpresa. Chegava eu dos Estados Unidos quando recebi a visita do secretário da embaixada, Fernando Buarque Franco, que vinha me informar de que eu havia sido nomeado e indicar a necessidade de minha ida a Nova York, para uma entrevista com o secretáriogeral U Thant. Fui sacudido ainda na minha perplexidade por um telegrama enviado por $U$ Thant, pedindo-me resposta a um telegrama que me remetera, mas que infelizmente não chegara às minhas mãos. A princípio relutei, mas, de comum acordo com minha mulher, resolvi aceitar o convite para ir a Nova York e discutir com o secretário-geral a minha nomeação.

Malgrado o temor que então tinha de avião, a viagem foi muito agradável, pois Silvia Amélia e Maria da Glória, duas de minhas filhas, me acompanharam. Ali chegado, verifiquei que se tratava de algo de grande porte, pois esperava-me na pista do aeroporto um carro oficial da ONU e o oficial de gabinete de $\mathrm{U}$ Thant, encarregado de me ajudar em meus primeiros momentos. Dirigi-me apressadamente à casa de meus amigos Adolf e Beatriz Berle, onde deveria ficar hospedado, e depois de um banho rápido fui à sede da instituição, início de um torvelinho que só terminaria um ano depois, e no correr do qual, além da minha presença quase constante em Genebra, visitei o Canadá, os Estados Unidos, a Grã-Bretanha, a União Soviética e os países da Europa continental.

Digo, com a maior sinceridade, que ainda tinha pretensões de não aceitar a proposta que me seria feita por $U$ Thant. Adolf Berle procurou me dissuadir das minhas intenções. Chegando ao edifício da ONU, fui rapidamente recebido pelo secretário-geral, uma das pessoas mais atraentes que tenho conhecido. Conversamos mais de meia hora. Expliquei-lhe como me considerava incompetente para tal posição. U Thant ouviu-me com a paciência e a calma características do cidadão oriental. Apenas de quando em vez um sorriso no olhar indicava o seu interesse pelo que eu estava dizendo. Era U Thant uma pessoa extremamente agradável, daquelas com quem se pode ter uma compreensão mútua ao primeiro encontro. 
U Thant disse-me que precisava de uma pessoa como eu: jovem, regularmente conhecido no mundo científico e oriundo de um país em desenvolvimento. Garantiu-me que me daria a mais ampla liberdade de ação e que, qualquer que fosse a decisão que eu tomasse, estaria sempre a meu lado. $\mathrm{Na}$ verdade, deixou pouco espaço para que eu recusasse o convite. Concedeu-me, também, uma condição especial que para mim apresentava vantagens: a de que eu só seria "funcionário" da ONU quando em contato direto com problemas da conferência, cujo objetivo era levantar o nível científico e tecnológico dos países em desenvolvimento. Como eu não desejava abandonar de todo o trabalho no Instituto de Biofisica, $U$ Thant liberou-me para que eu viajasse ao Brasil quantas vezes o trabalho em Genebra assim o permitisse. U Thant pôs-se de acordo comigo, assinalando apenas o prejuízo financeiro que isto me traria, pois que a ONU só poderia me pagar os dias em que eu estivesse totalmente ao seu serviço. Em seguida, já com a experiência adquirida em outras ocasiões e temendo a burocracia que tudo invade, disse-lhe, ainda, que para poder trabalhar com liberdade precisaria ter uma linha direta com ele, que poderia ficar certo de que eu não abusaria desse privilégio. U Thant concordou comigo e, no fim de algum tempo mais, firmamos um "acordo de cavalheiros" que durou todo o tempo em que a conferência se realizou.

Apresentou-me, logo depois da entrevista, a um funcionário da ONU, Katzin, natural da África do Sul, que seria encarregado da parte puramente administrativa da conferência. Um pouco truculento para o meu gosto, Katzin, que se havia notabilizado nas campanhas africanas de luta contra o domínio alemão, me ajudaria a fazer marchar a grande máquina que se estava preparando.

Voltei ao Rio e vinte dias depois segui para Genebra, deixando Annah e as quatro meninas. Em Genebra, hospedei-me no Hotel de La Paix, até que Annah viesse com minhas filhas ao meu encontro, ocasião em que aluguei um apartamento pequeno, mas muito simpático, no Parque de Budé. A rotina seguida foi sempre a mesma: chegar ao meu escritório às oito e meia, almoçar na própria sede da ONU ou em um dos restaurantes da cidade, e rapidamente reassumir o trabalho que ia se avolumando, e que, em geral, terminava em torno das vinte e duas horas, quando o meu secretariado já mostrava sinais de cansaço. A tarefa era pesada, pois mais de cem países se 
inscreveram para a conferência, enviando mais de três mil documentos, que foram reduzidos, pela análise feita por meus assistentes, para aproximadamente dois mil. Achei que não poderia, por ser demais oneroso, publicar, nas várias línguas das Nações Unidas, todos os documentos aceitos. Em conseqüência, organizei um comitê para fazer o resumo das idéias neles apresentadas, o que resultou na publicação de sete volumes, de aproximadamente trezentas páginas. Representou, na verdade, um trabalho mais do que intenso e, não fosse o grupo de colaboradores de alto nível, entre os quais Filomena BovetNitti, que me auxiliaram, dificilmente poderia ter sido realizado. Tive, durante os onze meses que vivi em Genebra, algumas turbulências, dificeis de serem evitadas.

Foi nessa ocasião, em Genebra, que conheci de perto o que é a dificuldade da convivência de homens de opiniões e raças diferentes, muitas vezes obcecados por filosofias políticas e até mesmo religiosas, que os tornam inimigos intratáveis. Vi, também, que se os homens têm esse comportamento indesejável, o mesmo se pode observar entre as nações, pois uma das maiores dificuldades que tive durante todo o trabalho foi a de tentar harmonizar as potências que se julgavam prejudicadas por decisões que eu havia tomado e que eram impostas pelas circunstâncias.

Tendo sido acordado que a conferência começaria pela exposição de certos assuntos, a escolha dos oradores para cada um deles foi dificil. Era eu procurado, diariamente, pelos chefes de delegação, que solicitavam, às vezes em atitudes que me obrigavam a reagir ao que diziam, a inclusão de tal ou qual dos seus patrícios na lista dos oradores. A URSS, a França e mesmo os Estados Unidos, vieram muitas vezes ao meu escritório, até na véspera da inauguração do certame, para dizer-me que seus países iriam se retirar da reunião caso eu não modificasse a decisão de ter entregue o relatório de um tema a um membro de outra delegação, e não à deles. Nesse sentido, a grande potência que melhor comportamento apresentou foi a Grã-Bretanha, que aceitou, sem discutir, todas as minhas decisões, o que não foi o caso da França, país com o qual eu mantinha relações em todos os níveis de interesse para a conferência.

Numa organização internacional, o pensamento corre mais rapidamente do que o vento, por mais veloz que este seja. Era quase impossível evitar a espionagem dentro dos próprios serviços que eu dirigia. Qualquer decisão 
minha, escrita ou até mesmo expressa oralmente a um interlocutor que eu imaginava de boa-fé, dava origem a uma corrente de informações que circulavam com rapidez no palácio onde trabalhávamos, e atingia, ainda com maior rapidez, o exterior, por mais distante que ele fosse.

O episódio mais grave ocorreu em conseqüência da idéia que tive de incluir entre os participantes da conferência um ou dois representantes "técnicos" da Alemanha Oriental, que não fazia parte da ONU. Procurei me comunicar diretamente com $U$ Thant para dizer da minha pretensão, com a qual ele concordou. Não sei como, mas não havia eu ainda tomado uma decisão final, nem escolhido o orador tedesco que eu iria convidar, quando entrou pela minha sala, batendo forte com os pés no chão, o delegado da União Soviética, que protestava contra a minha decisào, que só seria aceita pelo seu governo se a minha escolha recaísse em um dos três nomes que me indicou. Retorqui com certo vigor, do que ele se lembrou mais tarde num dos coquetéis realizados no fim da conferência. Se eu tivesse seguido a minha idéia, a organização da ONU teria então sofrido modificações, que só vieram mais tarde.

Diga-se de passagem que $U$ Thant aprovara a minha idéia e me autorizara a realizá-la. Só não o fiz pela intempestiva intervenção do delegado soviético. A atitude deste foi seguida, alguns minutos depois de sua saída da minha sala, pelo delegado dos Estados Unidos. Respondi a este da mesma maneira que respondi àquele. $\mathrm{O}$ único remorso que tenho da minha atividade na conferência foi o de ter finalmente cedido à pressão das duas potências. Isto me impediu de realizar uma abertura internacional, limitada exclusivamente ao domínio científico e técnico que, entretanto, seria útil para a humanidade.

Foi dificil, também, fazer com que certos conferencistas, pois que os havia quatro por dia, mantivessem seus discursos dentro da linha que havia sido ajustada previamente e pela qual cada postulante poderia defender a sua política de maneira a mais agressiva, mas deveria deixar de lado qualquer tipo de agressão a países com que existissem linhas de tensão política e social. Um dos casos que mais me irritaram foi o de um ilustre francês, que seria o meu porta-voz, se assim posso dizer, na questão da reforma agrária, e que era um sábio de grande renome internacional e, mais ainda, irmão de um dos meus mais íntimos amigos franceses. Em vez de expor a teoria do que deveria ser uma reforma agrária genuína, gastou ele o seu tempo de quarenta minutos em explicações minudentes sobre o que o seu país pretendia fazer na África. 
Tal fato obrigou-me a dirigir um comunicado a algumas delegações expressando o meu desapontamento, já que uma das metas que eu estava disposto a fazer progredir na conferência era a da ampliação da reforma agrária.

Para mim, a conferência foi extraordinariamente útil, malgrado a opinião de J. Oppenheimer, que encontrei um dia num dos cafés da Rive Droite. Muitos radicalizavam, avaliando que a Conferência de Genebra foi um fracasso: uma espécie de "feira" de ciência e tecnologia, em que os países poderosos vendiam os seus produtos, de maneira clamorosamente deselegante, aos países pobres. Eu não penso assim. O que me vem à mente é o reflexo de noites e mais noites maldormidas, nas quais discuti comigo mesmo e repensei todos os fatos que se passavam no âmbito da conferência. Estou convencido de que foi ela produtiva pelo que criou de novas idéias e novas perspectivas. Sobretudo, porque gerou o aparecimento de novas relações internacionais e mostrou que a aplicação da ciência e da tecnologia constitui um inesgotável horizonte para a civilização humana, que somente a sordidez e o egoísmo do homem podem destruir.

Creio que posso dizer que a conferência foi extremamente proveitosa para muitos dos países emergentes, os quais souberam aproveitar o que de importante ali se apresentou, pois não deixei que ela se transformasse apenas em um balcão de venda de tecnologia aos países subdesenvolvidos, com idéias e material científico as mais das vezes superados, o que era desejo das grandes potências. Mas, ao lado dessa pirataria científica, certamente muito foi aproveitado para a construção de uma base científica e tecnológica, em nações que apenas começavam a se estruturar. Acho que os vários volumes em que foram condensadas todas as idéias, ainda hoje, passados quase trinta anos, têm o seu lugar na mesa dos ordenadores da política científica de cada país.

Não posso deixar de assinalar que, nessa disputa indesejável de procura de mercado, e não de disseminação de idéias, uma potência se destacou pelo desprendimento com que participou dos trabalhos da conferência, a GrãBretanha, desfazendo, assim, o conceito de um colonialismo rígido. Talvez essa posição tenha sido conseqüência da sua extraordinária ligação com as próprias colônias, as quais se apresentaram numa posição de extremo progresso em relação a outras. 
Minha ligação com a ONU prosseguiu com a minha indicação para participar de um comitê constituído de quatorze membros, destinado a examinar a atividade conseqüente à Conferência de Genebra e, ao mesmo tempo, examinar novas propostas e novas situações surgidas no mundo. Esse comitê, que se reunia duas vezes por ano, teve, realmente, uma atividade fecunda. Entre os seus ilustres participantes estavam Pierre Auger, da França, G.K. Menon, da Índia, e Abdus Salam, do Paquistão, figuras do mais alto destaque da comunidade científica internacional. Abdus Salam, durante uma de nossas reuniões, comunicou-me o seu projeto para a criação de uma Academia de Ciências do Terceiro Mundo. Durante os últimos anos de sua existência, tive ocasião de presidir o comitê, tendo suas reuniões sido realizadas no meu escritório da delegação do Brasil, na Unesco. Foi aí que traçamos as linhas-mestras do que deveria ser a Conferência sobre o Meio Ambiente, que se realizou em 1969. Foi este o momento em que sem exageros, porém com uma vontade firme, tornei-me ambientalista, não no sentido profissional, mas naquele em que o ambiente vem a ser uma preocupação preciosa.

Participei, também, da atividade de outras duas organizações internacionais: a Organização Pan-Americana de Saúde (Opas) e a Organização Mundial de Saúde (OMS). Em ambas aprendi muito mais do que contribuí, mas pude me abeirar de alguns dos problemas mais pungentes da humanidade. Para a Organização Pan-Americana de Saúde, fui indicado por um jovem brasileiro, Maurício da Silva, ilustre pediatra que as dificuldades de um bom exercício da medicina, no Rio de Janeiro, levaram ao estudo dos problemas de saúde populacional. Foi ele um excelente membro da direção da Organização PanAmericana de Saúde, na ocasião dirigida pela sabedoria do chileno Abraão Horwitz. As reuniões bianuais levavam-me a Washington duas vezes ao ano. Na sede da organização encontrava-me com figuras exponenciais, como Bernardo Houssay, com o qual tive inúmeras divergências que, entretanto, não abalaram a minha admiração pelo seu trabalho, nem diminuíram o carinho com que ele acompanhava, muitas vezes discordando delas, as minhas intervenções. A atividade na Organização Pan-Americana de Saúde deu-me a impressão de um trabalho fecundo e de ação muito produtiva.

Já na Organização Mundial de Saúde, fiz parte do Comitê de Estudos dos Programas Experimentais. Fui a ele levado por um dos grandes brasileiros que conheci, com capacidade de organização e de visão extraordinárias: 
Marcolino Candau. Ao lado dele convivi, também, com Ernani Braga. São estes dois sanitaristas cuja contribuição ao Brasil não poderá nunca ser esquecida.

Minha permanência na OMS deu-me um vasto entendimento dos problemas que os países enfrentam na sua ação essencial para a vida do povo: a proteção de sua saúde. Fiquei sabendo que as diferenças étnicas e, até mesmo, culturais não proporcionam as dificuldades que a sociedade tem para enfrentar os problemas de saúde, estes intimamente ligados ao processo econômico, trazendo, em conseqüência, divergências que só poderão ser vencidas pela compreensão, por parte da sociedade, do que o povo realmente deseja.

Um dia, em janeiro de 1966, fui acordado muito cedo por um telefonema do presidente da República. Ainda um pouco sonolento, atendi ao telefone e, com espanto, verifiquei que o meu interlocutor era o próprio presidente. De início procurei disfarçar para verificar se não era um trote, ao que ele me disse que eu podia estar tranqüilo, pois era, na verdade, Castello Branco quem me falava. Depois de uma rápida conversa em que lhe pedi desculpas pela lentidão da minha interlocução, pois "não estava acostumado a que o presidente me chamasse ao telefone antes das sete da manhã" - e, diria mesmo, a nenhuma hora - , pediu-me ele que fosse vê-lo às onze e meia, esperando que eu fosse pontual, pois ele o era muito. Cheguei ao palácio na hora exata e logo fui recebido. Eu o havia encontrado uma única vez na casa de Ugo Pinheiro Guimarães, na rua Paissandu. O presidente, depois de algumas palavras de cortesia, disse-me que, provavelmente, eu não saberia a razão pela qual me havia chamado, ao que, com meu assentimento, declarou que desejava me nomear embaixador do Brasil na Unesco. Fiquei algum tempo perturbado, mas disse, de imediato: "Mas o senhor pretende tirar o Paulo Carneiro?” E um pouco petulantemente, acrescentei: "Paulo Carneiro é o homem mais importante no cenário intelectual da Unesco. Espero que essa sua decisão não seja irreversível, pois o Brasil sofrerá com a mesma." Disse-lhe que estava muito honrado pelo convite, mas que, além da dificuldade de não magoar Paulo Carneiro, eu tinha compromissos. O primeiro era que eu não gostaria de deixar a direção da faculdade, tanto mais que sentia que as minhas idéias eram partilhadas pelos meus colegas de congregação. $O$ segundo era que a Academia Brasileira de Ciências vivia em grande dificuldade financeira, sem nenhuma renda própria, e o terceiro era que eu 
precisava aparelhar melhor os serviços hospitalares da Faculdade de Medicina. $O$ presidente disse-me que a questão do meu substituto na faculdade não apresentaria dificuldades. Cabia a mim apresentar uma lista de três professores e que ele nomearia o que eu indicasse. Quanto aos recursos para a academia, que eu estudasse a melhor fórmula com Roberto Campos, a quem ele mesmo telefonaria. Assim foi feito. $\mathrm{O}$ candidato que eu escolhi na lista tríplice, para diretor da faculdade, foi o professor José Leme Lopes. Roberto Campos me atendeu prontamente, dando uma verba de um milhão de cruzeiros, que foi absorvida muito mais pela universidade do que pela Faculdade de Medicina.

A solução dada ao problema da Academia Brasileira de Ciências foi resolvida de uma maneira esplêndida. Castello Branco sancionou a lei n ${ }^{\circ} 5.092$, de $30 \mathrm{de}$ agosto de 1966, publicada no Diário Oficial, que autorizava o Poder Executivo a doar Obrigações Reajustáveis do Tesouro Nacional à Academia Brasileira de Ciências. $O$ valor dessas obrigações era de um bilhão e seiscentos e sessenta milhões de cruzeiros, com vencimento no prazo de vinte anos. Computados os juros de seis por cento ao ano, a soma recebida pela Academia Brasileira de Ciências corresponde a um total de setecentos e cinqüenta mil dólares, conversão feita levando-se em conta o valor do dólar no dia da publicação do decreto. Castello Branco tornou público o seu apoio à Academia Brasileira de Ciências no discurso que nela pronunciou, na ocasião da comemoração do cinqüentenário de sua fundação. Este foi, sem dúvida, um bom serviço que eu prestei à academia, embora alguns colegas meus tenham considerado, na ocasião, que o caráter temporário da ajuda não era o ideal.

À minha pergunta sobre Paulo Carneiro, Castello Branco respondeume: "A minha decisão é irreversível. O senhor reflita e venha depois me dar a sua resposta. Seria bom que o senhor mesmo comunicasse a minha decisão ao embaixador Paulo Carneiro." Saí estonteado do encontro e fui para casa, tendo chamado para presenciar o telefonema que eu iria dar ao velho amigo Paulo Carneiro, seu irmão Trajano. Pelo telefone, Paulo, na sua generosidade, disse: "Se eu tenho que sair, gostaria que meu substituto fosse você."

Depois de alguns dias, fortemente pressionado por Luiz Vianna Filho, voltei ao palácio para aceitar a minha indicação. Preparei-me, assim, para embarcar para Paris, o que levou ainda dois meses, pois o Senado só se 
reuniu um mês depois de chegada a respectiva mensagem do presidente e de realizada a sabatina a que fui submetido.

Não me foi dificil responder aos vários quesitos que me foram propostos, quase sempre muito simpáticos à minha pessoa. É que, no ano que passara, havia eu tomado parte em várias reuniões de interesse do programa da Unesco. Como membro do Comitê Consultivo da Organização PanAmericana de Saúde, fora algumas vezes a Washington. Dessas viagens tirei sempre grande proveito para incrementar o meu conhecimento sobre a vida científica internacional e sobre alguns problemas de educação, de interesse dos países em desenvolvimento e da própria Unesco.

Conhecia eu, bastante bem, o funcionamento dessa organização internacional, pois fui um dos delegados brasileiros à sua Primeira Conferência Geral, realizada durante um mês de árduos trabalhos, em Paris. Fui também delegado do Brasil à Segunda Conferência Geral, realizada no México, em 1947. O ambiente desta pôs-me em contato mais direto com os problemas latino-americanos e o desenvolvimento científico e cultural. Também alargou o horizonte dos meus conhecimentos a minha presença no Conselho Consultivo da Organização Mundial de Saúde, onde eram agitados, principalmente, problemas relativos aos países da África e da Ásia. A Conferência do México, das mais interessantes conferências internacionais a que tenho comparecido, além de acentuar a riqueza da nação hospedeira, das suas gentes, hábitos e cultura, ofereceu-me ainda a oportunidade, única, de me pôr em contato com personalidades da França que, posteriormente, vieram a prestar uma grande colaboração à minha atividade no Brasil. Entre elas cito: o reitor da Academia de Paris, professor Jean Sarraihl, profundo conhecedor da língua e da civilização espanhola; Louis Joxe, chefe do Departamento Cultural do Ministério das Relações Exteriores da França; e Paul Rivet, antropólogo cujos estudos sobre a população da América Latina foram importantíssimos para o conhecimento da mesma. Entre outros de igual nível intelectual, cito Jacques Maritain, com o qual me entretive longas horas, em debates às vezes controvertidos, sobre a personalidade de Bernanos e sua obra literária, esta, sem dúvida, incontestável.

A minha ida e adaptação ao trabalho na Unesco foi muito fácil. Tinha a me proteger a sombra dessa figura gigantesca que foi Paulo Carneiro, sem dúvida um dos seres mais perfeitos que conheci e que tanto me 
ensinou, desde os tempos em que me fez compreender as fórmulas das moléculas orgânicas, quando eu me preparava para o vestibular de medicina. Sempre pronto a me auxiliar naquilo de que eu necessitava, a me indicar os caminhos que eu devia seguir, foi com a maior emoção que o vi no Aeroporto de Orly, no dia da minha chegada a Paris. Uma das certezas que levo na vida é que nunca o magoei e procurei, o mais possível, mostrar a todos quanto pude, as qualidades extraordinárias desse varão único, em que se mesclavam as virtudes cristãs e a rigidez do puro pensamento filosófico de Auguste Comte.

Outro acontecimento que facilitou a minha vida na Unesco foi ter participado de uma Assembléia Geral para a discussão da política científica e tecnológica organizada pela ONU. Nesta, tive um papel preponderante ao não permitir que fosse avante um projeto dos países do Oriente, que desejavam a supressão das responsabilidades da Unesco em relação à ciência internacional, criando-se, para tanto, uma agência que representaria, ao mesmo tempo, novas frustrações, novos custos e mais empregos para intelectuais sem perspectivas no Terceiro Mundo. Custou-me muito obter o apoio necessário de certos páses emergentes, mas tive, no entanto, o dos países da América Latina, o qual, somado ao dos países ricos, eliminou a possibilidade dessa absurda criação.

Encontrei, também, desde o início da atividade que desenvolvi como chefe da delegação do Brasil junto à Unesco, o apoio permanente da Sessão de Cooperação Intelectual do Itamarati e, particularmente, do então secretário Hélio Scarabotolo. E ainda mais, o apoio decisivo de Adisheshiah, diretor-adjunto e, particularmente, de René Maheu, diretorgeral, durante todo o tempo em que exerci o meu posto. Gozei, como já disse, de uma grande ligação com essa eminente figura que foi René Maheu, na qual eu encontrei tudo aquilo que aprendi a admirar na velha França, até mesmo a sua caturrice. Trazia-me ele o reflexo já quase perdido do tempo da velha École Normale da Rue d'Ulm. Não sei mesmo se Maheu ali estudou, mas a sua formação é típica da ocasião em que aquela escola formou o grupo de escol que criou a França pós-napoleônica. Com Maheu havia eu adquirido certa intimidade, em conferências anteriores, o que me permitiu uma forma muito direta de entretenimento. Cada vez que o queria ver, convidava-o para um almoço num dos grandes restaurantes 
de Paris - éramos ambos gourmets -, tendo o cuidado de lhe enviar, na véspera, uma pequena agenda na qual se encontravam os temas que iria com ele discutir. Esses temas, na sua grande maioria, eram relativos ao Brasil ou à América Latina, mas, em parte, diziam respeito à própria atividade da Unesco.

Lembro-me da satisfação com que Maheu se referiu a um documento que lhe enviei mostrando a importância de uma modificação global do currículo do Segundo Ciclo, em geral sobrecarregado com matérias de interesse intelectual, mas de pouca utilidade civil, e o reforço, no mesmo, das línguas nacionais em muitos países, quase sempre marginalizadas pelo esquecimento de que a cultura de um país é, em parte, uma função do desenvolvimento de sua própria língua. Uma iniciativa à qual Maheu deu o maior apoio foi a organização, em 1967, de um simpósio internacional de pesquisa sobre "o cérebro e o comportamento humano". Para este simpósio tive todo o apoio do diretor-geral da Unesco. Pude escolher um pequeno comitê de organização que trabalhou, duramente, na sua realização e, até mesmo, consegui levar à Europa, para me auxiliar diretamente, um brasileiro e companheiro de trabalho, Darcy Fontoura de Almeida, ilustre pesquisador da área de biofísica, que me acompanha, fielmente, desde o início da minha atividade. $\mathrm{O}$ colóquio teve a maior aceitação e mais de seis Prêmios Nobel dele participaram, dando um brilho extraordinário às reuniões que encheram vários dos anfiteatros da sede da Unesco, em Paris.

Um dia, surpreendeu-me Maheu enviando-me um dos seus chefes de serviço para convidar-me a fazer parte da Comissão Internacional de Salvaguarda de Veneza. Fiz-lhe ver que me faltava competência para tanto, mas ele não se convenceu e assim, durante anos, tive a oportunidade única de reviver, na velha cidade dos doges, os limites que separam as civilizações que se sucederam no mar Mediterrâneo, experiência de fertilidade única para a compreensão da vida e o estudo da humanidade. Maheu tinha, talvez, uma excessiva confiança em mim. Por duas vezes escolhi, para ele, novos diretores: Carlos Flexa Ribeiro, para diretor de Educação, e o geneticista italiano Adriano Buzzatti-Traverso, para a Ciência.

Uma das cartas que recebi quando o governo brasileiro, abruptamente, mas para o meu bem, me retirou da Unesco foi escrita por Maheu. É uma carta que releio com emoção, na certeza de que, durante a minha passagem 
por aquela instituição, fiz o melhor que pude, ainda que longe do que desejaria ter feito. Assim dizia a carta:

\section{Vendredi, 21 Novembre 1969}

Cher ami,

A mon retour d'Asie, je trouve votre lettre du 19. La nouvelle qu'elle m'apporte me choque et me peine profondément.

Je m'habituerai difficilement d̀ ne pas vous avoir d̀ mês cotés, vous qui n'avez cessé d'être pour moi un appui sans défaut, un encouragement constant et généreux, une source inépuisable d'idées. Du moins ai-je la satisfaction de pouvoir en tout lieu compter sur votre amitié. Je vous écris ces quelques lignes encore sous le coup de l'émotion, dans la melée des affaires qui, comme d̀ chaque retour, m'assaillent de toute part.

Elles me sauraient en aucune matière constituer le témoignage d'admiration et de reconnaissance que j'espère avoir l'occasion de vous manifester avant votre départ.

Veuillez les accueiller cependant, ainsi que Madame Chagas qui a toujours été si compréhensive et si bonne pour moi et à qui je vous prie de renouveler mes respectueux hommages, comme l'expression très sincère de mes profonds regrets et l'assurance de ma fidele amitié.

René Maheu

A minha saída da Unesco foi-me muito proveitosa. Já havia realizado a minha missão e, se mais tempo ficasse fora do Brasil, ser-me-ia muito dificil continuar aquilo a que me havia proposto, seja a implantação de uma atividade de pesquisa científica contínua, na minha universidade.

O meu intercâmbio com Maheu fez-se por intermédio de numerosas cartas e oficios (cerca de duzentos) que lhe enviei regularmente, no periodo entre 1966 e 1970. O assunto dessas minhas comunicaçōes é bastante variado, relativo, amiúde, a atividades próprias da Unesco, porém, as mais das vezes, ao Brasil ou à América Latina. Esse meu intercâmbio é apresentado a seguir, resumidamente, pois não me é possivel analisar todas as minhas mensagens a Maheu, limitando-me, na exposição que se segue, apenas a algumas sugestões:

Em carta enviada em 9/6/1966, peço apoio para um workshop sobre neurobiologia, no Chile, e assinalo que a idéia preconcebida de que a pesquisa sobre cérebro só poderia ser levada a cabo nos países desenvolvidos parecia destituída de fundamento. Havia todo um trabalho a fazer sobre a etologia humana nos povos que não tinham recebido, ainda, a marca da civilização moderna, países nos quais o comportamento social merece uma atenção 
que sobrepassa os limites das ciências sociais e se insere nos aspectos biológicos, vale dizer, nas pesquisas cerebrais propriamente ditas. Sendo tão óbvia a importância das pesquisas no domínio do cérebro, em minha opinião, deveriam entrar no programa da Unesco. Seria, pois, interessante estabelecer um acordo de cooperação Unesco/Ibro (International Brain Research Organization), esta em dificuldades financeiras. Tais considerações me levaram a apresentar um projeto de resolução que garantisse a continuação da Ibro, o apoio para o workshop sobre neurobiologia e, ainda, que se consolidasse a idéia da realização de uma conferência científica sobre "O cérebro e o comportamento humano". Ambos foram realizados com grande sucesso em Santiago do Chile e em Paris, respectivamente.

Outra preocupação que me inquietava era a necessidade de se conceber um plano integrado para a conservação da natureza e para a proteção e salvaguarda dos bens artísticos no Brasil, ameaçados pela crescente penetração das rodovias para o Oeste e, eventualmente, pelo desenvolvimento da atividade turística. Achava imperativo efetivar-se o entrosamento e a colaboração entre o Serviço do Patrimônio Histórico, o Departamento Nacional de Estradas de Rodagem, a Academia Brasileira de Ciências e o CNPq, numa planificação global que levasse em consideração uma perspectiva largamente aberta à conservação dos bens artísticos e de certos patrimônios naturais. Seria necessário integrar tudo isso nos projetos de desenvolvimento do país. Ressaltei, ainda, as possibilidades para o turismo nas cidades do litoral, como Salvador ou Parati, sem deixar de lado as cidades antigas do interior, indispensáveis ao bom conhecimento do barroco em nossas plagas, com referência especial à cidade de Goiás Velho. Terminei sugerindo que a Unesco enviasse missão para avaliar as questões expostas. Uma das conseqüências dessa sugestão foi o tombamento da área do Pelourinho, em Salvador, Bahia.

O estímulo à iniciação científica e ao estudo da natureza sempre foram objeto das minhas cogitações de homem devotado à ciência e ao magistério. Dessa forma, fiz ver quão benéfica seria a criação de um programa contemplando esses dois aspectos. Tal programa seria desenvolvido com a ajuda de um kit preparado pelo Instituto Brasileiro de Educação, Ciência e Cultura (Ibecc), de São Paulo. Seria também de grande valia a realização, pela Unesco, de cursos preparatórios para professores de ensino primário 
que se envolveriam com o projeto de iniciação às ciências. Deles deveriam participar professores da América Latina e da África. Essas considerações decorreram da análise crítica que fiz do programa então elaborado pela Unesco, o que me levou à conclusão de que o incremento dado ao ensino das "ciências fundamentais" era muito reduzido.

Solicitei o apoio justificado da Organização à Primeira Exposição Surrealista Internacional, que seria realizada em São Paulo, em maio de 1967, e mostraria sua importância para a difusão dos princípios fundamentais do pensamento surrealista. Uma das suas conseqüências seria a de impulsionar, em linhas modernas, o desenvolvimento intelectual.

Propus modificação no mecanismo de realização da Conferência Geral da Unesco, e insisti na formação de um comitê consultivo, escolhido pelo diretor-geral, dentro das regras que determinavam o seu funcionamento.

Levei ao conhecimento do diretor-geral a minha contribuição ao Congresso Americano, perante o qual pronunciei uma conferência sobre "Ciência e Tecnologia nos Países em Desenvolvimento”, assinalando, mais uma vez, as dificuldades de comunicação. Por fim, voltei ao tema da realização de uma conferência sobre educação científica e da necessidade da formação de quadros científicos.

Dinigi-me ao diretor-geral para formular as linhas gerais pelas quais deveriam ser criadas e organizadas as faculdades de ciências, financiadas pelo fundo especial das Nações Unidas, e no quadro das atividades da Unesco. Dois pontos seriam essenciais: a utilização do que chamei "a estrutura ecológica local", e o emprego de "métodos os mais avançados". Reforcei, então, o meu ponto de vista de que, sempre que possível, o centro de ensino científico esteja ligado ao sistema universitário e, ao mesmo tempo, focalize os problemas mais característicos da sociologia e da natureza de cada região.

Explicitei minha inquietação com a migração de talentos e a pobreza do número de bolsas da Unesco. Assinalei a importância de um justo equilíbrio entre as bolsas dadas no campo das ciências sociais e das ciências chamadas exatas, sem o qual não haveria possibilidade de se criar o humanismo científico. Nesse contexto, fiz um comentário sobre a dificuldade de se encontrarem, por falta de entrosamento com a Unesco, interlocutores realmente válidos no campo das ciências humanas e sociais. Com relação à Terceira Sessão de Informações, apresentada pelo diretor-geral, enfatizei a 
importância da criação de centros de excelência e a sua possível transformação em centros de formação avançada.

Chamei a atenção para a importância de se dar mais enfoque aos projetos nacionais e internacionais, do aspecto plástico que se encontra na ciência moderna e que vai desde o domínio atômico-molecular às dimensões galácticas. Desse ponto de vista, poder-se-ia prever uma profunda interpenetração entre a criação artística e o que se poderia chamar "a estética da profissão científica". Uma exposição desse tipo serviria para estabelecer novo laço entre as atividades do espírito humano que, entre os vários campos, são entretanto separadas pelo quadro material, no qual evolui, respectivamente, a vida do artista ou do cientista.

Mencionei, ainda, a importância de um seminário sobre a formação de administradores científicos e, para tal, a necessidade da organização de cursos de informação científica para jornalistas, assunto que poderia ser desenvolvido pela Unesco.

Ressaltei a necessidade de esforços para a criação de uma Faculdade de Ciências na Bahia. Mais ainda, enviei carta indicando o interesse na fabricação simples e elementar de equipamento científico para o ensino básico.

Fiz considerações sobre a importância do projeto apresentado na $14^{2}$ Conferência Geral, intitulado "O homem e o meio", felicitando, ao mesmo tempo, o diretor-geral pelo interesse que o mesmo estava suscitando no secretariado. Seguem-se considerações sobre as favelas, assinalando a influência do meio sobre o comportamento humano.

Em seguida, considerações sobre a migração definitiva ou temporária, bem como sobre as dificuldades de adaptação que a mesma oferece, propondo que a Unesco criasse um sistema pelo qual os cientistas que tivessem migrado pudessem visitar, regularmente, seus países de origem.

Falando sobre Brasília, elogiei a idéia da utilização dos centros de excelência para intensificar, no plano regional, o ensino superior de pósgraduação. Apresentei uma lista de onze centros situados em universidades brasileiras e capazes de colaborar com a Unesco neste projeto. No campo da Física, assinalei a importância do Centro Latino-Americano de Física, localizado no Rio de Janeiro, e das várias universidades brasileiras capazes de prover um curso de física de alto nível e com característica de pósgraduação. 
Indiquei a importância da criação de uma escola de técnicos, com caráter regional e semelhante à que foi organizada em Belo Horizonte, graças à colaboração do Department of Overseas Cooperation, da Grã-Bretanha, do British Council e do Conselho Nacional de Pesquisas.

$\mathrm{Na}$ carta 153, propus um projeto de colaboração do Instituto Francês do Petróleo com a Unesco, para implantar, no nordeste do Brasil, a indústria de produção de proteínas pela alga Spirulina maxima.

Insisti, também, sobre a importância do esforço que a Unesco deve fazer para a formação de quadros de cientistas e técnicos nos países em desenvolvimento, assinalando que a Unesco deveria imaginar um tipo de universidade capaz de desenvolver, nesse domínio, as potencialidades de cada nação.

Sugeri ao diretor a criação de um centro de música no nordeste do Brasil, que serviria, sobretudo, para o estabelecimento de um estudo da música latinoamericana, seja na época colonial, no período clássico, ou na época moderna. O centro deveria servir, também, para a ordenação da música folclórica.

Insisti na reformulação dos interesses da Unesco no sentido de uma integração maior entre ciências exatas e ciências sociais. Ainda, procurei estimular a publicação da revista Impacto, que exerceu, durante um certo tempo, grande influência nos meios científicos e intelectuais, acentuando o seu caráter de independência e, particularmente, a não-competição com as revistas de leitura usual, tais como Nature ou Scientific American, sugerindo que a Unesco deveria se ocupar, principalmente, com a política científica nos países em desenvolvimento.

Propus que cientistas ou especialistas dos países em desenvolvimento pudessem realizar estágios de até vinte e quatro meses nos serviços da Unesco, não só visando ao seu próprio aprendizado como, também, para difundir, nos países de origem a ação daquela organização.

$\mathrm{Na}$ minha volta da Mesa-Redonda sobre Política Cultural, realizada em Mônaco, felicitei o diretor-geral e o sub-diretor-geral, senhor Elmandjrá, pelo sucesso da mesma, assim como assinalei as dificuldades da ação da Unesco no campo cultural, já que neste os problemas têm um caráter nacional, e esse caráter deve ser protegido, tornando assim mais dificil uma política de educação e desenvolvimento cultural.

Em outra carta, assinalei que o esforço deveria ser renovado nos domínios culturais, pois que o desenvolvimento social, que deve ser o objetivo do 
desenvolvimento econômico, não pode ser obtido senão pela valorização do que há de mais imanente na vida de cada país ou região, e que a atividade da Unesco deveria ser dirigida, cada vez mais, nessa direção. O ideal de paz que nos conduz não será atingido, senão, pelo respeito internacional baseado na dignidade humana, fortalecida pelo crescimento das características da alma coletiva, o pleno desenvolvimento da cultura e defesa dos direitos de cada indivíduo, e não baseada no desenvolvimento das riquezas materiais, cujo traço mais característico é a procura, em nossa civilização, dos bens de consumo.

Voltei a falar, em outra ocasião, sobre a criação das Faculdades de Ciências e sugeri a organização de um centro de educação para crianças anormais, citando o exemplo da experiência realizada em Belo Horizonte, na Fazenda do Rosário, pela senhora Helena Antipoff.

Fiz, também, um apelo para que a Unesco organizasse exposições itinerantes de ciências, semelhantes às que observei no Palais de la Découverte, que seriam de grande utilidade nos países de pouco desenvolvimento científico.

Apresentei as possiveis linhas de trabalho resultantes do colóquio sobre "o cérebro e o comportamento humano".

Propus que a Unesco publicasse uma edição especial das obras de Manuel Bandeira para ser largamente difundida, conjuntamente com o disco do festival realizado em Provence, onde poemas e canções do poeta, traduzidos belamente para o francês por Michel Simon, foram interpretados por artistas franceses.

Em outra oportunidade, fiz observações sobre a distribuição geográfica e a necessidade de respeitar competências na distribuição dos trabalhos da organização, assim como assinalei a importância da utilização dos computadores nos trabalhos da Unesco e nos países em desenvolvimento.

Apresentei considerações restritivas sobre a nova organização da Divisão de Ciências da Unesco, acentuando a necessidade de um melhor desenvolvimento do setor de educação científica e, além do aumento de bolsas da Unesco e sua racionalização, sugeri a importância de um convênio Unesco/Ibro.

Defendi a realização, no Palácio da Unesco, de uma exposição sobre o marechal Cândido Rondon, que sucederia àquela feita em homenagem a Nehru. A exposição teria, também, o objetivo de silenciar os detratores do Brasil que proclamavam nosso interesse desumano no extermínio dos indígenas. A exposição, orçada em quinze mil dólares, não foi realizada, pois 
não obtive o interesse da divisão cultural do Itamarati, embora a idéia tivesse sido aceita pelo diretor-geral da Unesco.

Sugeri a edição, pela Unesco, de dois livros: $O$ índio brasileiro e a Revolução Francesa, de Afonso Arinos de Mello Franco, e $A$ superioridade do homem tropical, escrito por Silva Mello. Uma análise dos livros está incluída no oficio enviado. Faço, ainda, a proposição de ser organizado e publicado um volume sobre o barroco brasileiro.

Mencionei, na carta 180 , a idéia de um novo sistema para difusão das atividades da Unesco nos Estados-membros.

Apresentei projeto para a criação de uma Faculdade de Ciências em São José do Rio Preto, São Paulo, e lancei o nome de Alexandre Eulálio Pimenta da Cunha para oficial de ligação entre a Unesco e a Comissão de Salvaguarda de Veneza. Ainda, mostrei ao diretor o grande interesse pelos trabalhos realizados em Salvador sobre radioatividade natural, dando a idéia da visita, ao Brasil, do professor Laberye.

Ao despedir-me do diretor-geral, em carta de 20/1/1970, sugeri que a Unesco servisse de centro internacional de informação e formação de quadros, no domínio do ensino para crianças e adolescentes excepcionais, já que as condições do hábitat moderno da vida, que se desenvolve em nossa civilização, para não me referir somente às modificações de certas regras de comportamento, nos informavam que, num futuro próximo, o número de retardados aumentaria vertiginosamente. Parece que o tratamento bioquímico, bemsucedido em alguns casos, ou o exame pré-nupcial não modificariam o problema senão de uma maneira ilusória. Seria necessário, pois, integrar esses seres humanos na sociedade, dando-lhes "uma certa viabilidade econômica".

Insisti, ainda, para que a Unesco realizasse como função fundamental uma reformulação do ensino secundário, o qual não correspondia mais ao progresso de nossa sociedade. E mais, que a Unesco deveria criar uma sonoteca internacional para preservar os ritmos primitivos das coletividades. Esse assunto passa despercebido numa sociedade voltada para o progresso mecânico e na qual raros são aqueles que experimentaram e foram tocados pelo ritmo invasor, perturbador e extraordinário de uma noite passada na floresta tropical ou nas savanas. Nessas noites, tem-se a impressão de ouvir vozes não humanas provindo das árvores e das plantas, interrompidas, de tempos em tempos, pelo canto de animais noturnos. 
Acrescentei, ainda, que no momento em que as prioridades científicas estavam concentradas nas pesquisas sobre o cérebro, as quais podem levar a uma parte da explicação do comportamento, consciente ou inconsciente, não se poderia eliminá-las de uma organização como a Unesco. Enfatizei, também, o seguinte:

Por razões que nâo sei explicar, numerosos são aqueles que consideram, infelizmente, que a pesquisa sobre o cérebro deve ser um privilégio dos países desenvolvidos. Se nós considerarmos o custo do estabelecimento de um laboratório de pesquisa sobre o cérebro, só posso admitir que essa atitude tenha origem numa discriminação intelectual. Infelizmente, muitos dos cientistas dos países desenvolvidos consideram que certas pesquisas superam não somente as capacidades materiais dos países em desenvolvimento, mas as capacidades intelectuais de seus pesquisadores. Ora, isso é um grave erro. Para enfrentar todos os problemas de seu desenvolvimento, estes últimos países devem, ao contrário, desenvolver as pesquisas sobre o cérebro, não só como pesquisas de base, mas também de aplicação.

E assim concluo a minha carta:

É pois, em nome de toda uma região de um país em desenvolvimento, seja do Terceiro Mundo, que eu vos dirijo este apelo, na espera de que ele receberá a generosa atenção que sempre foi dada às minhas outras iniciativas.

Uma das atividades que desenvolvi simultaneamente às da Unesco foi a organização da reunião do Comitê para o Desenvolvimento Científico e Tecnológico dos Países em Desenvolvimento, que eu então presidia, para a apresentação ao Conselho Econômico e Social da ONU de um projeto de organização da Conferência sobre Meio Ambiente, que veio a se realizar em 1972, em Estocolmo.

A estada na Unesco foi extremamente produtiva para mim. Além de viver em Paris, o que não é negligenciável, tive a oportunidade de conhecer o mundo por intermédio das inúmeras personalidades que, vindas dos quatro cantos do globo terrestre, participavam das atividades da organização, seja a título permanente, como funcionários, seja como representantes-delegados, seja como participantes das várias reuniões, quase que diárias, com que a entidade fazia caminhar os seus projetos. Entre os funcionários, muitos conheci da mais alta qualidade intelectual e moral. Cito, apenas como exemplo, o senhor Yves de Emptine, chefe da divisão de política científica, 
em cujo entretenimento muito aprendi. É falaciosa a tendência de achar que funcionários internacionais são homens e mulheres que fogem dos seus países para viver em melhores condições de trabalho e de vida. A grande maioria, direi mesmo, a quase totalidade daqueles com quem convivi, era constituída por pessoas que tinham realmente o ideal de contribuir para o progresso da civilização.

Entre os delegados e os representantes nacionais, conheci alguns que se destacavam pelo seu amor à causa internacional e ao progresso da humanidade. Foi, sem dúvida, minha estada na Unesco uma experiência riquíssima, vivida, cada minuto, com satisfação e interesse. 


\section{VIII}

\section{As academias}

7 ive a oportunidade de presidir duas academias de ciências. A primeira, 1 a Academia Brasileira de Ciências, no Rio de Janeiro, como mencionei antes. A segunda, a Academia Pontificia de Ciências, no Vaticano, de 1972 a 1988, o que me levou a Roma, pelo menos, duas vezes por ano.

À presidência da Academia Brasileira de Ciências fui eleito pela generosidade de Arthur Moses, que a presidira durante mais de vinte anos e levou-a à sua atual sede na rua Anfilófio de Carvalho, no centro da cidade. Nessa ocasião, estive várias vezes em entretenimento com o ilustre bacteriologista, pois desejava convencê-lo a instalar a academia num belo edifício da rua Dona Mariana, o qual possuía um vasto terreno e uma construção secundária, onde poder-seia instalar uma pousada para visitantes nacionais e estrangeiros, convidados da academia. Meus argumentos foram vãos, pois Arthur Moses achava que nós, da comunidade científica, estávamos acostumados às reuniões plenárias quinzenais que se realizavam no edifício da Escola Politécnica, no Largo de São Francisco, e que nos permitiam, acabadas as sessões, formar rodas de conversação e discussão em alguns dos bons bares existentes no antigo edificio do Hotel Avenida. Neles, quantas vezes, malgrado a diferença de idade, me entretive com homens da estatura intelectual de Álvaro Alberto, Miguel Ozorio, Francisco Venâncio Filho e Roquete Pinto, entre outros.

Um dia, Arthur Moses chamou-me ao seu laboratório particular na rua da Quitanda e, para surpresa minha, declarou que sentia-se cansado e desejava se afastar da presidência da Academia Brasileira de Ciências. Para minha 
maior surpresa, indicava-me para sucedê-lo. Insisti muito para que ele não desistisse do cargo que, com tanta nobreza e exatidão, ocupava sem nenhuma divergência grave a perturbá-la. Disse-me que sua decisão era definitiva. Arrependo-me, até hoje, de não ter insistido mais para que ele a modificasse, porque, sem dúvida alguma, foi ele um presidente de qualidade inexcedível. A surpresa de seu convite foi grande, porque havia ele deixado o Instituto Oswaldo Cruz e me haviam dito que Moses divergira da orientação administrativa de meu pai. Estava eu errado, pois que, nas várias vezes em que conversamos sobre as lutas que meu pai travara na Academia de Medicina e na reforma que fizera na Saúde Pública, Arthur Moses, talvez timidamente, sempre elogiara meu pai.

Era um cargo importante a que eu nunca havia almejado, mas que, de modo algum, poderia recusar. Chegado o momento da eleição, a academia, em sessão plena, elegeu-me presidente por um periodo que deveria ser de quatro anos. Tive apenas um voto contra - para minha surpresa, de um grande amigo - e um voto em branco, o meu próprio.

Minha atividade como presidente da Academia Brasileira de Ciências foi de apenas dois anos (1964-1965). Mesmo assim, pude prestar um serviço que considero relevante, com a doação obtida do presidente Castello Branco, quando me chamou para ser embaixador do Brasil na Unesco, como já relatei. Modifiquei também um pouco os hábitos de trabalho daquela instituição, reunindo-me com a diretoria uma vez por semana. Dessas reuniões participou, quase regularmente, o embaixador Hélio Scarabotolo, que, no Ministério das Relações Exteriores, ocupava a seção na qual se decidiam os acordos cien-tíficos, multi ou bilaterais, que o Brasil estabelecera ou estava estabelecendo com os governos de outros países.

Um episódio marcou a minha curta passagem pela presidência de nossa academia. No dia da minha posse, à qual compareceu o presidente Castello Branco, recebi, ao fim da solenidade, um documento de grande importância firmado pelos meus amigos da velha casa de Oswaldo Cruz. Meus companheiros de Manguinhos protestavam contra a administração que fora, de certa maneira, imposta por um grupo de militares da Escola Superior de Guerra. $O$ documento foi-me entregue por um dos meus melhores e mais admirados amigos: Walter Oswaldo Cruz. Foi este o mais brilhante dos meus companheiros de geração, tendo, desde cedo, mostrado em seus trabalhos de pesquisa e na 
sua capacidade de formação de discípulos mestria só encontrável nos grandes cientistas de todos os tempos.

Rapidamente decidi o que deveria fazer com o documento a mim apresentado. Resolvi, para isso, convocar uma sessão especial da academia limitada aos membros do Instituto Oswaldo Cruz, que fossem acadêmicos, para discutir o que se estava passando na instituição que é a minha alma mater. Essa sessão realizou-se no dia 4 de agosto de 1966. Aos presentes expliquei, inicialmente, a razão de suas convocações, pois, na verdade, a academia não podia fugir à responsabilidade de defender a autonomia científica do Instituto Oswaldo Cruz e de cada um de seus pesquisadores. Dois campos se formaram. Em um desfilou-se a série de turbulências ocorrentes no instituto e que, mais tarde, foram compendiadas por Herman Lent no seu livro $O$ massacre de Manguinhos. No outro, fez-se a defesa da situação existente, sendo que coube a Olímpio da Fonseca Filho a responsabilidade de representar esse grupo.

Foi uma sessão para mim extremamente angustiante, pois que naquele dia nascera o meu primeiro neto, que sofrera, logo depois do nascimento, duas paradas cardíacas. Fui obrigado a acompanhar o seu estado de saúde pelo telefone, até que terminou a sessão na qual as discussões, embora acerbas, nunca chegaram a superar os limites da educação. Em seguida, fiz um resumo do que havia sido debatido, debate no qual o grupo de crítica ao diretor de Manguinhos saíra-se vantajoso, e entreguei meu relatório, juntamente com o documento que fora trazido por Walter Oswaldo Cruz, ao ministro da Casa Civil no Palácio das Laranjeiras, Luiz Vianna. Acho que fiz o que era possivel fazer. É que o diretor combatido tinha todo o apoio da Escola Superior de Guerra.

Aliás, sobre o episódio, permito-me contar um fato interessante, ocorrido em outra situação. Estava eu em Paris quando encontrei, no Café de Paris, Walter Oswaldo Cruz e sua mulher. Conversa vai, conversa vem, disse-me ele estar satisfeito com a nova direção dada ao instituto, dirigido agora por um ilustre cardiologista, que se tornara famoso por seus trabalhos sobre as cardiopatias chagásicas. Obtemperei-lhe que, malgrado minha admiração várias vezes expressa, tanto pelo médico como pelo especialista, creio que lhe faltavam o renome e a convivência com problemas de administração suficientemente grandes, para nomeá-lo para o cargo. Sua grande vantagem 
era a de ser médico de Getúlio Vargas. O que eu disse ao Walter, eu já havia dito ao próprio cardiologista, quando ele veio, certa manhã, à Praia Vermelha, convidar-me para diretor de Manguinhos, em nome do presidente Vargas. Disse mais, ao Walter, que uma nomeação desse tipo daria margem a nomeação de pessoas - e dei-lhe um exemplo - não qualificadas para o cargo, que havia sido ocupado por Oswaldo Cruz, por meu pai e por Cardoso Fontes. Quando Walter chegou ao Rio, a nomeação do candidato que eu indicara como simples palpite já havia sido feita. Naturalmente, nunca consegui convencer Walter de que eu de nada sabia, quando com ele conversara.

Decorridos alguns meses, deixei para me substituir na presidência da academia, Aristides de Azevedo Pacheco Leão, seguindo então para Paris. Tempos depois, fui a Genebra participar de um comitê de pesquisas médicas na Organização Mundial de Saúde. Aproveitei a volta, já que estava de automóvel, para percorrer os lindos campos da França central, visitando com cuidado a Borgonha. Cheguei a Paris no meio da noite. No dia seguinte, fui acordado muito cedo pelo núncio apostólico em Paris, Righi-Lambertini, que manifestou o desejo de ver-me com urgência. Se possível, às onze horas daquele mesmo dia. Àquela hora encontrava-me no escritório de Lambertini, quando uma porta se abriu e apareceu-me uma figura de grande porte, na qual eu senti, desde logo, a fina educação do alto clero romano. Era o futuro cardeal. Depois das frases de apresentação, disse-me ele que o papa Paulo VI convidava-me para ser presidente da Academia Pontificia de Ciências. Confesso que fiquei tão atônito que, atabalhoadamente, perguntei-lhe se tinha certeza do que estava me dizendo. Monsenhor sorriu e mostrou-me o telegrama que o fizera chamar-me. Não podia imaginar que tal atribuição pudesse me ser conferida. Na verdade, havia sido eleito para a Academia Pontificia poucos anos antes (1961) e participara apenas de uma das reuniões plenárias, que nela se realizam periodicamente.

Estávamos em 1972. Agora, decorridos vinte e seis anos, ainda me pergunto quem terá indicado o meu nome a Sua Santidade. Penso que influíram a voz de dom Eugenio Sales e a do cardeal Benelli, que me conhecera quando estava eu na Unesco e era ele o observador do Vaticano. Com Benelli, estabeleci relações bastante cordiais, continuação dos entretenimentos que havíamos tido no Rio, ainda que esparsos, quando Benelli era um dos membros 
da Nunciatura Apostólica. Com monsenhor Lambertini ficou combinado que eu iria a Roma no prazo mais curto possível. Assim foi feito. Surpreendime quando, ao chegar ao Aeroporto de Fiumicino, encontrei um carro com placa do Vaticano à minha espera. À tarde, veio o mesmo buscar-me e fui diretamente ao palácio papalino para me encontrar com Paulo VI, o que foi para mim uma surpresa, pois pensava que primeiro teria que ver o cardeal substituto Villot, e com Benelli, que, logo depois, seria feito cardeal de Florença.

Realmente, o convite me surpreendeu. Minha fé sempre foi profunda e eu creio que ela chegou a mim por intermédio de minha mãe, da Fräulein, alemã católica de quatro costados, e vovó Mariana, mãe de meu pai, que vivia sempre com um terço na mão. A minha religiosidade eu penso tê-la adquirido, principalmente, na Fazenda da Tartária, onde tantos verões passei. Ali, antes de irmos dormir, juntávamo-nos todos, os tios, os primos, as visitas, os colonos mais próximos da casa da fazenda, para rezarmos juntos o terço, recitado em voz alta, tio Henrique comandando a oração. Influiume, também, ao que assisti nas Semanas Santas passadas em Oliveira. No Rio, entretanto, naquela ocasião, eu pouco freqüentava a Igreja da Glória do Largo do Machado, a mais próxima da minha casa. Minha mãe tinha uma grande fé, mas sua religião era um pouco particular. Tanto assim que, de um momento para o outro, passou a ir à missa aos sábados — bem antes de essa concessão ter sido feita por Roma - pois, nos domingos, tinha a obrigação de ajudar a preparação do almoço no qual se juntavam sempre amigos, como Figueiredo Rodrigues, Armando Godoy, o comandante Chagas Moura e, até o seu rompimento com meu pai por motivos de serviço, Belisário Penna, e outros ainda. Nesses almoços conheci a fina flor do sanitarismo brasileiro de então. Mais tarde, em parte por curiosidade intelectual e, em parte, para me encontrar com Annah, segui um curso sobre tomismo, ministrado por frei Secondi. Creio que a personalidade deste, encantadora, carinhosa e altamente humana, foi um dos fatores que mais me aproximaram da Igreja Católica. Durante toda a sua vida, tive a oportunidade de encontrálo com freqüência e, cada vez que o fiz, dele recebi uma lição de humanidade e espiritualismo. No entanto, os grandes líderes intelectuais do catolicismo no Rio, como Alceu de Amoroso Lima, que conheci melhor, Jackson de Figueiredo, que não conheci, e até mesmo Sobral Pinto, não tiveram nenhuma 
influência sobre mim, embora eu os admirasse e, particularmente, a Tristão de Athayde.

No entanto, havia alguma coisa que me impedia de maior aproximação com a Igreja. Quem derrubou esse obstáculo foi Georges Bernanos quando, em Barbacena, tinha eu ido para tratar-me de uma primoinfecção tuberculosa, em 1942. Muito mais tarde, em Roma, tive a oportunidade de conhecer um dos maiores servidores da Igreja, o dominicano Enrico di Rovasenda, que foi chanceler da Academia Pontificia de Ciências de 1964 até 1986. O que ganhei com a sua convivência é indescritível. Afável, altamente intelectual, tinha o humanismo e o liberalismo como características de seu pensamento cheio de uma fé inamovível. Todas as minhas dificuldades com interpretações "fundamentalistas" de católicos por demais zelosos eram rapidamente superadas pela capacidade dialética do ilustre sacerdote. Foram discussões inesquecíveis, aquelas vividas no silêncio da Casina Pio IV, rodeada pelos jardins do Vaticano, linda sede da Academia Pontificia de Ciências. Rovasenda havia sido engenheiro antes de entrar para o convento, tendo, ainda estudante, participado das lutas da juventude antifascista na era de Mussolini. Dedicara uma grande parte de seu tempo à criação da dinâmica associação dos Laureati Cattolici, uma das forças importantes do movimento contra a ditadura. Digo que, sem Enrico di Rovasenda, o sucesso de minha missão como presidente da Academia Pontificia de Ciências não teria existido. Até o presente, mantenho com Rovasenda uma correspondência que me é de salutar efeito.

A minha ida direta a Paulo VI pareceu-me, e o foi, um bom presságio. Meu encontro com o papa Montini terá sido momento dos mais emocionantes pelos quais tenho passado na vida. Anteriormente, havia visto de perto e em condições especiais o papa Pio XII, figura impressionante. Passando por Roma em 1947, fomos levados pelo secretário da Embaixada do Brasil, Galvão Bueno a assistir a uma bênção de Pio XII aos soldados italianos que, a comando do governo fascista, iam colonizar a Abissínia, hoje Etiópia. Meu primeiro choque e emoção deram-se quando a figura esguia e austera do papa Pacelli entrou no grande salão onde se realizou a cerimônia. Além da solenidade da ocasião, Pio XII apresentava gtande semelhança com Afrânio de Mello Franco, meu sogro.

A segunda emoção foi produzida pelo forte, para não dizer violento, discurso com que Pio XII censurou o governo da Itália e aconselhou aos seus 
ouvintes que procurassem seguir, na sua "dificil missão", os passos de compreensão e justiça que nos ensinou Jesus. Meu ânimo, indignado diante da truculência dos governos nazistas, dobrou de alegria com as palavras do papa. Esse momento é inesquecível.

Outro Sumo Pontífice que conheci foi o papa Roncalli, João XXIII, a quem coube dar início aos estudos do Vaticano II. João XXIII era uma figura da maior simpatia. De formas opulentas, seu olhar meigo e seu sorriso simpático não podiam ocultar a profundidade do pensamento de quem recebia a cátedra de São Pedro em momento de grande agitação nos meios religiosos, civis e eclesiásticos. Bonachão, tinha a estrutura humana que mais tarde vim a encontrar nos camponeses do norte da Itália. Da primeira vez que com ele estive, já acadêmico da Pontificia Academia de Ciências, perguntou-me sobre o Brasil, querendo que eu fosse a detalhes. Estávamos, como disse, numa época de agitação política e movimentos sociais. À sua pergunta sobre qual a solução que eu propunha para o Brasil, disse-lhe de imediato: "A reforma agrária." Fixou-me por alguns minutos e depois, apontando para o chão, disse-me que a cada momento de sua "dificil missão" - e o qualificativo é dele - pensava em nosso país e que nunca deixava de orar por ele nas suas missas. Sem dúvida, João XXIII transmitia uma força interior extraordinária, ao mesmo tempo que se sentia nele um homem apegado à terra, às gentes e aos seus problemas.

Minha primeira entrevista com Paulo VI foi encantadora, como todos os vários contatos que com ele tive. Era o papa Montini um homem simples, de convívio agradabilíssimo. Sentia-se nele, entretanto, uma auréola de angústia a que o levavam, principalmente, os acontecimentos do mundo e a realização próxima do Concílio Vaticano. Todas as minhas sugestões foram por ele aceitas, o que me permitiu pedir a nomeação de seis novos membros do maior valor, como Rita Levi-Montalcini e Jerôme Lejeune, sem a anuência do conselho da academia, que eu, aliás, ainda não havia formado. A nomeação de Rita Levi-Montalcini tinha dois significados: o de ser ela mulher e hebréia. Quanto a Jerôme Lejeune, que ainda não havia tomado as posições radicais que veio a assumir, sua presença fazia-se necessária por não haver na academia um geneticista de nomeada.

Durante as inúmeras ocasiões em que tive a oportunidade e a honra de estar com Paulo VI, essa impressão de preocupação cada vez mais se afirmava. 
Perguntou-me ele, no primeiro encontro, que pretendia eu fazer como presidente da Academia Pontificia. Não hesitei em dizer-lhe que queria fazer dela uma academia de ação, ao lado do prestígio que lhe dava sua posição de estar diretamente ligada a Sua Santidade. Lendo o livro de Régis Ladous, Des Nobels au Vatican, publicado recentemente, verifiquei que, sem ter conhecimento prévio, penso que por inspiração superior, disse ao papa que Pio XI, o grande reformador da Academia Pontificia, expressara, nos seus discursos à academia e no regimento que estabelecera em 1936, que os membros da academia deveriam ser escolhidos apenas pelos seus méritos científicos, sem distinção de raças e sem nenhuma outra discriminação, nem mesmo religiosa. Pedi, também, a Paulo VI, autorização para elaborar um novo regimento, que substituísse aquele promulgado por $\mathrm{Pio} \mathrm{XI}$, já superado pelo extraordinário progresso da ciência nos últimos cinqüenta anos. $\mathrm{O}$ regimento que elaborei foi promulgado pelo Santo Padre sem nenhuma modificação.

No mesmo dia em que fui recebido por Paulo VI, foi me ver no hotel o doutor Pietro Salviucci, que, com o título de chanceler, dirigia o secretariado da Academia Pontifícia. Salviucci representava, verdadeiramente, os arquivos da academia. Altíssimo e bem magro, uma cigarrilha pendente sempre dos seus lábios, fora professor de matemática no ensino secundário. Era essencialmente um romano de velha tradição, sua família conhecida pela capacidade de dominar o trabalho de publicações. Havia sido indicado para trabalhar na academia a pedido do presidente Gemelli, e a ela se dedicara de corpo e alma. Foi meu secretário-geral durante pouco tempo, pois havia atingido o limite de idade para funcionários do Vaticano, servindo-me com a maior lealdade, embora, acredito, não estivesse de acordo com muitos dos meus projetos. Deu-me, também, durante todo o tempo em que trabalhamos juntos, grande contribuição, informando-me sobre as atividades pregressas da academia e sobre o entrelaçamento da atividade que eu ia exercer e os outros órgãos do Vaticano.

A Academia Pontificia de Ciências foi criada em 1502 por Federico Cesi, duque de Acquasparta, que pretendia reunir, em uma de suas propriedades, todos aqueles interessados nos fenômenos naturais. Cesi a denominou Academia dos Linces, por considerar que esses animais são capazes de enxergar mais longe, o que seria o caso dos cientistas. Resumindo um pouco sua 
história, direi que a academia fundada por Cesi viveu com altos e baixos, até que o governo italiano a absorveu com o nome de Accademia Nazionale dei Lincei, no momento em que se fez a concordata entre o Estado Italiano e o Vaticano, em 1870. Algum tempo depois é eleito papa Pio XI, que resolveu dar nova força à Academia dos Linces. Para isso cercou-se de um sacerdote da mais alta valia, o jesuíta Agostino Gemelli. Havia este participado na Primeira Guerra Mundial como piloto de aviões de combate. Voltando á Itália, resolveu dar maior vigor a um pequeno estabelecimento de ensino superior em Milão, transformando-o na Universidade do Sagrado Coração. Assumiu, fogosamente, a direção de certas associações católicas suspeitas de convicções antifascistas e fez frente a enormes dificuldades na organização de sua universidade, que tinha que manter relações com o governo de Mussolini. Foi Gemelli um sábio conselheiro de Pio XI que, depois de muita meditação, reformulou a Academia de Cesi, transformando-a, em 1936, na atual Academia Pontifícia de Ciências. Esta tinha tido, desde o início, o apoio do papa Benedito XV, interessado em lutar pela paz, já que se tornara evidente que as nações européias preparavam-se para uma contenda armada. Benedito XV acreditava que os cientistas podiam servir melhor do que qualquer outro profissional ao estabelecimento de uma harmonia internacional, cada vez mais ameaçada pelos movimentos que se haviam formado na Espanha e na Europa oriental.

Os pontos mais importantes no novo regimento foram estabelecidos por Gemelli e muitos deles pareceram por demais liberais a muitos elementos da Cúria e, até mesmo, a católicos de todo o mundo.

Dando andamento às minhas idéias já expostas ao papa Paulo VI, procurei, desde logo, realizar um tipo de reunião que servisse para focalizar alguns problemas científicos de grande significação para a sociedade e do maior interesse para a compreensão da evolução do mundo. Haveria grupos constituídos, no máximo, de dez membros, cientistas de todo o mundo. Escolhidos nos termos do regimento, mas não pertencentes necessariamente ao quadro da academia, completariam a atividade das sessões plenárias, muito mais amplas, e das quais deveriam participar todos os acadêmicos. Essas reuniões deram, certamente, uma grande divulgação aos trabalhos da academia, sendo que suas atividades e conclusões seriam difundidas sob a forma de monografias, artigos etc. Permitiram essas reuniões levar ao Vaticano, nos dezesseis anos 
em que presidi a academia, aproximadamente mil e quinhentos cientistas oriundos de todas as partes do mundo.

Dos dois grupos de trabalho iniciais, o primeiro dedicou-se ao estudo da dessalinização da água, dada a importância que tem esta para a vida e a sua paulatina diminuição no globo. E o segundo, aos estudos sobre a origem da vida, tendo em vista o reconhecimento da existência, em condições laboratoriais especiais, de moléculas pré-bióticas. Permitiram eles, também, a ida ao Vaticano de cientistas provenientes de nações sem laços diplomáticos com a Santa Sé. Nessa ocasião, apareceram, em certos meios menos esclarecidos, críticas à minha atuação, que teria tendência de judeizar a academia. Essa interpretação deformada do meu pensamento ocorreu em conseqüência da predominância de especialistas israelenses na semana de estudos sobre dessanilização, tendência essa natural pela importância dos trabalhos realizados em Israel para a produção de métodos de dessalinização. Permitiram elas, também, levar à Casina Pio IV alguns dos novos acadêmicos, como Severo Ochoa, que se ocupou, principalmente, das moléculas prébióticas.

Durante o tempo em que presidi a Academia Pontificia de Ciências, fiz organizar várias "semanas de estudos". Nelas foram discutidos assuntos da maior importância não só na área científica como também na social. Uma das mais significativas foi a que tratou dos métodos utilizados para a prorrogação da vida e que concluiu que esses métodos, economicamente pesados, devem ser suspensos somente quando ficar demonstrada a morte cerebral do paciente.

Acho, todavia, que o que mais profundamente marcou a minha passagem pela presidência da Academia Pontificia foi o movimento em prol do combate à guerra nuclear, a datação do Santo Sudário e, ainda, a reabertura do Processo Galileu.

Quando cheguei a Roma, preocupava-me, já, o movimento para o desenvolvimento da energia nuclear e de suas possibilidades bélicas. Aprendi isto na ocasião em que fiz parte do Comitê de Estudo da Ação das Radiações Ionizantes sobre os Seres Vivos, organizado pelas Nações Unidas. Acho curiosa a atitude daqueles que fazem mofa desses comitês internacionais. Este ao qual pertenci, nas Nações Unidas, permitiu-me conhecer de perto aquilo que me fora dado apreender por meio de livros e revistas. 
Conseqüentemente à minha passagem pela Comissão da ONU, dei início, no Instituto de Biofisica, como já me referi, a um maior esforço no Setor de Radiobiologia, chefiado por meu companheiro Luiz Renato C. da Silva Caldas, um dos melhores especialistas no assunto em nosso país, profundo conhecedor de todos os aspectos da questão, tendo, além do mais, feito parte, durante dois anos, do Secretariado da Comissão da ONU. Integrou esse esforço, com destaque, a série de palestras sobre o assunto, o projeto chefiado por Eduardo Penna Franca sobre os efeitos das areias monazíticas de Guarapari, Espírito Santo, e os cursos sobre a aplicação de radioisótopos em biologia e medicina.

Partindo dessas experiências, fiz com que a Academia Pontificia tomasse uma posição firme contra a utilização da mesma para fins bélicos. Para isto, convoquei uma reunião de presidentes das academias científicas de todo o mundo, à qual compareceram mais de sessenta representantes, para a elaboração de um documento que mostrasse ao mundo o verdadeiro perigo que a energia nuclear pode representar. Esse documento, assinado unanimemente por todos os presidentes e representantes das academias, na presença de Sua Santidade João Paulo II, em setembro de 1982, foi posteriormente entregue, por determinação do papa, aos presidentes e primeiros-ministros das quatro potências possuidoras de armas nucleares, assim como ao embaixador Kittani, presidente da Assembléia Geral das Nações Unidas, e ao secretário-geral desta, Kurt Waldheim. A mensagem da academia foi entregue a Ronald Reagan por Severo Ochoa, Victor Weisskopf e Howard Hiatt. A de Margaret Thatcher, o Prêmio Nobel Max Perutz e eu mesmo a levamos. A Mikhail Gorbachev, foram entregá-la Marini-Bettòlo e o nobelista belga Christian De Duve. E, finalmente, a de François Mitterrand chegou pelas mãos de Leprince-Ringuet e Jerôme Lejeune. À exceção do grupo que visitou o presidente dos Estados Unidos, Ronald Reagan, os demais delegados da academia foram recebidos com a maior cordialidade pelos chefes-de-estado. Um pouco mais tarde, em conseqüência de formulações errôneas dos jornais romanos, resultantes de uma entrevista que dei à imprensa na Casina Pio IV, os jornalistas publicaram que a academia havia tomado uma posição contra a chamada "guerra nas estrelas", assunto que nunca fora a debate no seio da instituição que eu presidia. Meu desmentido não teve a menor divulgação e, em conseqüência, pelo que fui 
informado mais tarde, o presidente Reagan enviou um emissário especial para solicitar, de João Paulo II, uma desaprovação da atitude jamais assumida, na realidade, pela Academia Pontificia.

Sobre esse documento, fontes oficiais dos países possuidores de armamento nuclear nunca se manifestaram, o mesmo não ocorrendo, entretanto, com organizações acadêmicas e organismos não-oficiais, que se manifestaram favoráveis às conclusões nele contidas. Infelizmente, no Brasil, esse importante documento teve sua repercussão minimizada pelo interesse que o desenvolvimento da energia nuclear inspirava em muitos de nossos dirigentes.

Outro momento saliente da minha presença na academia foi o da datação do Santo Sudário. Encontrando-se o mesmo em Turim, onde representa o que de mais importante existe na cidade, o cardeal Ballestrero foi ao Santo Padre pedir que a academia procedesse à datação do mesmo. Tentei, então, demover Sua Santidade de tomar tal iniciativa, pois afirmava que a datação poderia dar a idade do Sudário com uma aproximação, no melhor dos casos, de cem anos, para mais ou para menos, e que, no momento, a datação não serviria para uma demonstração precisa de que a expressiva face desenhada no Santo Sudário fosse a de Jesus Cristo. Meus argumentos foram vãos, e, assim, ajudado pelo professor Vittorio Canuto, da Nasa, convoquei uma comissão especialista em datação pelo carbono-14. Recentemente, o professor Harry E. Gove, que dirigiu o trabalho da comissão de técnicos escolhidos por mim e por Canuto, publicou um livro em que relata todos os fatos: Relic, Icon or Hoax?. Esse livro, editado em 1996 pelo Institute of Physics Publishing de Bristol, tem tido boa repercussão nos Estados Unidos. O resultado da datação levou à conclusão de que o tecido onde está estampada a imagem da cabeça de Jesus fora feito no ano 600 d.C. Essa constatação causou profunda emoção em vários meios religiosos e, particularmente, na cidade de Turim. Embora eu nunca tenha feito a menor tentativa de perturbar o trabalho da comissão, o resultado final causou-me apreensão, pois, certamente, milhares de católicos, como eu mesmo, teriam preferido que o tecido tivesse sido elaborado nas vizinhanças da data do nascimento de Jesus. Vários grupos na cidade de Turim e em outras cidades da Europa tentaram discutir o resultado, chegando alguns leigos a pôr em dúvida a capacidade dos peritos que haviam feito a datação. Quero crer que muitos desejavam que a datação confirmasse a hipótese de o Santo Sudário ter envolvido o 
corpo de Jesus Cristo. Porém, o resultado objetivo não permitiu mais que assim se pensasse. A publicação com os detalhes da operação, como se encontram descritos no livro de Gove, e amplamente difundidos pela imprensa européia, tornaram as reclamações sem significação, e rapidamente o resultado da experiência científica foi esquecido.

Outra iniciativa foi encaminhar os trabalhos da academia para o estudo do Processo Galileu. Quem me chamou a atenção, inicialmente, da importância de um reexame da atitude da Igreja em relação a esse grande sábio, foi o cardeal da Áustria, König, que veio de Viena dois ou três dias depois da minha posse, especialmente para discutir o assunto comigo. Em uma entrevista com João Paulo II, toquei no assunto, assinalando que o Processo Galileu era uma constante crítica dos agnósticos à Igreja Católica. João Paulo II nada me disse no momento, mas na primeira vez que se dirigiu em público à academia, referiu-se a Galileu. Tratava-se de uma reunião especial em homenagem ao centenário de Albert Einstein, muito justa homenagem, aliás, visto que a academia nunca o chamara para o seu seio. João Paulo II referiu-se a Galileu e a Einstein dizendo que enquanto este nunca fora incomodado pela Igreja, Galileu sofrera, da mesma, forte perseguição, incitando a que a academia retomasse o estudo do Processo Galileu, o que foi feito logo a seguir por uma comissão presidida pelo cardeal Martini, de Milão. Sem dúvida, foi um serviço que se prestou à nossa Igreja. Um dos resultados positivos desse trabalho é o fato de que todo o processo de Galileu, que se encontra na biblioteca do Vaticano, pode hoje ser visto por pessoas credenciadas. Parece-me que essa abertura aproximará mais a ciência da Igreja.

Quero crer que a minha atividade na academia correspondeu ao que eu propus a Paulo VI. Na verdade, realizei, nos dezesseis anos em que a presidi, mais ou menos vinte e cinco semanas de estudos, além de grupos de trabalho das sessões plenárias anuais e mesas-redondas. Não só renovei os métodos de trabalho, como também pude nomear para a academia o maior número de cientistas mulheres, representantes das comunidades científicas judaica e muçulmana, bem como personalidades agnósticas. Graças ao apoio que recebi de João Paulo II, nunca tive dificuldades ou atritos com a Cúria Romana, nem mesmo quando realizei uma semana de estudos sobre experimentação biológica moderna, assunto em certos pontos de extrema 
delicadeza, e um grupo de estudos sobre inseminação artificial. A única reação contra este foi a de um alto prócer do Vaticano, que resolveu fazer o seu próprio grupo de trabalho para o mesmo assunto. $O$ resultado da reunião não teve a menor repercussão, ao contrário daquela que realizei, e à qual esteve presente, entre outros, Jerôme Lejeune, de extraordinária capacidade científica e intelectual, e cuja fidelidade às determinações da Santa Sé não poderia ser posta em dúvida.

Guardo da minha passagem pela presidência da Academia Pontifícia de Ciências extraordinária recordação. Nela convivi com duas personalidades de características diferentes, mas de excepcional valor humano e intelectual: o papa Montini e o papa Wojtyla. Aquele, parecia reservado e ansioso. Este, ao contrário, aberto e tranqüilo. Entretanto, nunca deixei de saber o que pensavam a respeito das propostas que lhes fazia. Paulo VI, algumas vezes, deu o beneplácito dois ou três dias depois ao que eu propunha. Wojtyla dava-me a sua opinião quase que no momento em que eu acabava de expor a minha pretensão. Diferentes no físico, eram iguais no desejo de bem servir à Igreja e à humanidade.

Reservaram-me, os dois, duas das maiores emoções que tive em minha vida. A primeira foi a da entrega, por Paulo VI, da medalha da academia ao físico inglês Stephen W. Hawking. Quase sem movimentos, pois atingido por uma esclerose em placas, Hawking, transportado por uma enfermeira e por sua mulher, em uma cadeira de rodas, dava a impressão de um corpo quase sem substância. Sua cabeça e os grandes olhos azuis encimando larga boca mantinham-lhe um aspecto juvenil. Era ele o decifrador de um importante fenômeno conhecido como "buraco negro", sobre o qual, depois de seus trabalhos, centenas de astrônomos se debruçaram. A academia decidiu entregar-lhe a sua mais alta distinção, a Medalha de Ouro Pio XI. A solenidade foi emocionante. Na Sala Real do Vaticano inúmeros convidados comprimiam-se. Para a emoção de todos os presentes, Paulo VI levantou-se do seu trono e ajoelhou-se aos pés de Hawking, colocando ao redor do seu pescoço o precioso símbolo do reconhecimento. Raros foram aqueles que puderam resistir à cena e que não enxugaram, com seus lenços, as boas lágrimas que haviam tomado conta de seus olhos.

O outro evento que gostaria de citar foi o da beatificação de Maximiliano Kölbe. João Paulo II presidiu a todo o cerimonial, ao qual estiveram presentes, 
com seus uniformes de prisioneiros de Auschwitz, inúmeros companheiros de Kölbe no terrível episódio do campo de concentração. Entre esses prisioneiros, estava aquele que Kölbe havia substituído, heroicamente, no caminho da câmara de gás. Aí, também, os presentes não puderam resistir e raríssimos foram os que contiveram as lágrimas, no momento em que foi tocado o hino do campo dos prisioneiros massacrados por Hitler.

Minha atividade na academia foi extraordinariamente auxiliada pela singular figura do dominicano padre Enrico di Rovasenda, que substituiu o antigo secretário-chanceler Pietro Salviucci.

Quando deixei a presidência da Academia Pontificia, em 1988, passei algum tempo julgando se minha atividade fora boa ou má. Não posso deixar de confessar que, com grande pesar, vi o meu mandato se extinguir, mas, pensando sobre o que realizei, acho que fiz até mais do que podia, considerando que eu não residia em Roma e lá permanecia duas, no máximo três vezes por ano, por tempos variáveis de três semanas a quatro meses. O que havia prometido a Paulo VI, seja informar à Santa Sé dos principais acontecimentos e orientações da ciência, eu havia realizado, mas ficou-me a certeza de que quem lucrou com essa permanência em Roma fui eu mesmo. Ampliou-se, de maneira extraordinária, o honzonte de minha modesta cultura. Arraigaram-se, ainda mais, meus sentimentos de ligação com o poder espiritual, sem perder, de nenhum modo, minhas idéias de liberdade e de esperança. Cada momento que vivi em Roma deu um pouco mais à minha vida.

Creio ter sido uma ousadia a minha pretensão de entrar para a Academia Brasileira de Letras. Dois motivos me levaram a tanto. Primeiramente, a vaidade, pois penso que ninguém se apresenta candidato a uma academia sem um componente de vaidade nesse desejo. $O$ segundo, foi o de querer ocupar um lugar que meu pai desejou e nunca conseguiu. Lembro-me de que quando da morte de Miguel Couto, seu grande exemplo, houve em nossa casa um certo movimento para isto. Nesse momento entra em cena Tristão de Athayde que, impulsionado por várias correntes, apresenta-se candidato. Imediatamente, meu pai desistiu da sua intenção, pois sabia não só do prestígio de Alceu, como também não tinha dúvida da terrível oposição que a ele faria Afrânio Peixoto. Desse modo, sua candidatura nunca se formulou. Aliás, Alceu um dia procurou-me dizendo que não sabia que meu pai teria sido candidato. 
À primeira vaga a que me apresentei fui derrotado por Gildázio Amado, ilustre jornalista cujas crônicas sobre o Rio de Janeiro encantavam a todos nós. Pouco depois dessa eleição ocorreu a morte de Marques Rebelo, o grande romancista da vida carioca. Não pretendia me candidatar, tão de imediato, após minha derrota. Encontrei-me por acaso com Silva Mello, que insistiu para que eu me inscrevesse, assinalando que "devia eu me apresentar enquanto meus amigos ainda viviam". Essa frase me perturbou um pouco, mas levou-me a me inscrever contra um admirável escritor, José Cândido de Carvalho. Dediquei-me, então, a fazer as visitas de candidatura. Enquanto algumas pessoas me dizem que essas visitas são penosas, eu sustento o contrário. Fui sempre extremamente bem recebido por todos a quem procurei. Lembro-me, particularmente, da hora e meia em que me entretive com Elmano Cardim, que me incentivou muito na minha pretensão. Esta levou-me a conhecer Mário Palmério, em Uberaba, e Gilberto Freyre, no Recife. De todos recebi muito boa aceitação. Lancei, também, um livro, que deu início à série de volumes que tenho publicado. $O$ minuto que vem (Ed. Tempo Brasileiro, 1972) é a coletânea de meus trabalhos aparecidos em jornais e revistas, anteriormente. A eleição não foi fácil. Venci-a no quarto escrutínio, por apenas um voto. É bem verdade que o meu "adversário", escritor admirável que se tornou meu amigo, tanto merecia ser acadêmico que se elegeu logo depois. Tenho pela academia a maior apreciação e considero, realmente, um grande privilégio a ela pertencer.

$\mathrm{Na}$ ocasião em que fui candidato e me elegi, era seu presidente uma figura de singular significação na vida brasileira: Austregésilo de Athayde. Eu o havia conhecido na casa de Ana Amélia Carneiro de Mendonça, onde, com um grupo de jovens, entre os quais cito particularmente Luiz Simões Lopes, que considero um dos mais valiosos brasileiros que conheci, entretinha-me com freqüência. Minhas relações com Ana Amélia, grande dama brasileira, dataram da época em que, eleita rainha dos estudantes, um grupo de rebeldes quis diminuir o seu prestígio na ocasião em que lhe foi prestada uma homenagem no Teatro Municipal. A temperatura subiu muito e, em companhia de Hildefonso Mascarenhas, enfrentei um entrevero com estudantes menos respeitosos. Nas várias vezes em que fui à rua Marquês de Abrantes, ali me encontrei com Austregésilo, que, não sabia eu, fazia a corte a Maria José, irmã de Ana Amélia. Austregésilo recebeu-me na academia, 
penso que, a princípio, com certa dificuldade, que logo se dissipou quando nossa convivência tomou-se mais freqüente. Guardo, entretanto, do ilustre varão, uma grande impressão. Seu conhecimento, vale dizer, sua erudição eram de uma inteligência superior, bem como suas intervenções em ocasiões de debate, nas sessões acadêmicas. Guardo, também, do ilustre presidente, saudades do carinho com que me tratou durante todo o tempo em que convivemos, malgrado divergências de opinião muito freqüentes.

Assistir a uma sessão vespertina da academia é algo de extremo interesse. Os acadêmicos estão sempre alertas a todos os movimentos intelectuais que se passam no Brasil e no exterior, e têm um vasto conhecimento profundo da vida intelectual de nosso país. $\mathrm{Na}$ comemoração de efemérides, trazem ao nosso conhecimento uma análise penetrante de acontecimentos ou pessoas nelas envolvidos, dando a impressão de que conhecem profundamente nosso Brasil, suas gentes, seus expoentes, sua vida nos seus mínimos aspectos. As sessões das quintas-feiras são, para mim, uma lição de humildade.

Meu primeiro livro, Homens e coisas de ciência, foi publicado pela Universidade do Brasil, em 1956, e nele faço uma apreciação sobre ciência e cientistas. Mais tarde, em 1972, a Ed. Tempo Brasileiro lançou O minuto que vem. Em 1979, Cultura e ciência foi lançado pela UFRJ e FUJB (Fundação Universitária José Bonifácio), como parte da Coleção Memória. A Casa de Oswaldo Cruz, da Fundação Oswaldo Cruz, publicou, em 1991, o livro de ensaios Conceitos e contraconceitos e, em 1993, Meu pai, biografia de Carlos Chagas.

Pertenço, ainda, a algumas academias nacionais e estrangeiras. Posso afirmar, no entanto, que nunca solicitei a minha admissão a qualquer uma delas. Fui aceito na Academia Brasileira de Ciências por indicação de Álvaro Alberto. Tornei-me membro da Academia Nacional de Medicina quando Osvino Álvares Pena passou de titular a emérito, para que eu pudesse participar das festividades comemorativas do cinqüientenário da descoberta da Doença de Chagas, já como acadêmico. Para membro associado da Academia de Medicina de Paris, fui proposto por Pasteur Vallery-Radot. $O$ diretor do Instituto Pasteur, Jacques Tréfouel, foi quem me fez membro associado do Instituto de França. Marcel Florkin me levou a membro da Academia Real de Medicina da Bélgica, e Celestino da Costa, a membro da Academia de Ciências e Letras de Lisboa, às quais se juntam a American 
Academy of Arts and Sciences, a Accademia dei Quaranta, de Roma, a Academia de Medicina de Buenos Aires, a American Philosophical Society e a All India Academy of Sciences, entre outras. Contribuí para a criação da Academia de Ciências da América Latina (Acal), motivado pelo entusiasmo de Raymundo Villegas, eminente pesquisador venezuelano, tendo sido eu seu primeiro presidente. Participei, de maneira significativa, na criação, por Abdus Salam, da Academia de Ciências do Terceiro Mundo, com sede em Trieste. Do mesmo modo, algumas universidades estrangeiras outorgaramme títulos de Doutor Honoris Causa: quatorze ao todo. Cito, entre elas, três, por seu relacionamento com a nossa cultura: a de Paris, título que meu pai também recebeu, a de Coimbra e a de Salamanca.

Entre outros títulos, fui também feito cidadão honorário da cidade de Oliveira, Minas Gerais, e pesquisador honorário do Conseil National de la Recherche Scientifique e da Fundação Oswaldo Cruz. 


\section{IX}

\section{Lembranças afetivas: viagens, camaval e Annah}

$\mathrm{M}$ inha vida durante o período da faculdade, e mesmo depois, quando eu já trabalhava no Instituto Oswaldo Cruz, decorreu num Rio de Janeiro diferente do de hoje. Além do mais, na minha falta de preocupações mais sérias, não tomava eu conhecimento da miséria que já se alastrava morros acima, mas ainda não tinha invadido o âmago da cidade. Achava, também, que a presença de meu pai na direção do Departamento Nacional de Saúde Pública era uma segurança de que os problemas sanitários seriam resolvidos, em mais ou menos tempo. Por isso mesmo, podia me dedicar, ao lado dos esportes (basquetebol, à noite; esgrima, duas vezes por semana), a uma vida social que, não sendo muito intensa, pois eu dava muita importância aos estudos, era, assim mesmo, animada. Ocupava-me bastante de música, sendo, como disse, freqüentador assíduo, ainda que de carona, do Teatro Municipal. Óperas, concertos e balés contavam sempre com a minha presença. Houve um momento em que a sociedade carioca ficou com a mania dos patins de quatro rodas e improvisaram-se rinques em vários clubes. Eu ia sempre ao do Fluminense. Sem ser a grande estrela, era um bom patinador, o que facilitou mais tarde patinar no gelo, quando fui viver na Suíça.

A primeira vez que eu saí do Brasil para uma viagem aos Estados Unidos foi em 1919, quando acompanhei meu pai, minha mãe e Evandro, meu irmão. Foram quinze dias em um vapor da Munson Line, onde me beneficiei muito aperfeiçoando meu inglês, bastante primitivo. Para tanto ajudoume, enormemente, o alemão que aprendera com a Fräulein Elza Dingues. 
A tripulação com quem eu conversava entendia perfeitamente a minha mistura de inglês com alemão. Viagem tranqüilíssima, sem nenhum contratempo. A chegada a Nova York foi um deslumbramento! De início, a Estátua da Liberdade e, em seguida, os arranha-céus que eu desconhecia totalmente. No começo, ficamos hospedados no Hotel Macalpin, bem em frente à Estação Pensilvânia, que me pareceu gigantesca. Depois, quando meu pai começou sua viagem pelos Estados Unidos para pronunciar conferências em várias universidades, fui morar com meu tio Helio Lobo, cônsul-geral do Brasil, no Riverside Drive. Ali morei até nossa volta para o Brasil, quase três meses depois, já que meu pai foi também ao Canadá, onde, em Toronto, visitou Best e Banting, descobridores da insulina. Era também a sua primeira viagem à América do Norte e, pelo que me contou minha mãe, foi recebido gloriosamente nos vários centros científicos que visitou, tendo, logo de início, recebido o título de Doutor Honoris Causa na Universidade de Harvard. Sua visita a Toronto trouxe outro resultado importante. É que logo que nós voltamos para o Brasil, minha mãe apresentou sinais de diabetes, o que fez com que meu pai se dirigisse aos dois médicos de Toronto, que passaram a lhe enviar, com todas as precauções necessárias, vidros de insulina, logo depois comercializada pela companhia Lilly, o que permitiu uma sobrevida de mais de trinta e quatro anos à Mãezinha.

Em Manhattan fui a vários museus, porém, o que mais marcou minha passagem, foi a visita que meu pai, um pouco contra a minha vontade, obrigoume a fazer ao Instituto Rockefeller, onde assombrei-me ao visitar Alexis Carrel no seu laboratório.

Vestido numa bata verde e acompanhado por todos os seus assistentes, mostrou-me ele um pedaço de um coração de cobaia batendo normalmente. Era o início da cultura de tecidos desenvolvida particularmente, nos anos seguintes, na Alemanha. Tive muito contato, também, com meninos americanos, que se juntavam nos parques que margeiam o Riverside Drive, para jogar beisebol. Logo me ajustei ao jogo. Tive alguns entreveros, porque, pelo fato de usar calças curtas, até que minha mãe comprou-me as calças bombachas que os meninos americanos usavam, era eu chamado, com um certo desprezo, de French boy. Um dia, um dos garotos atarracados e bem mais fortes do que eu abusou da caçoada. Revidei. Cheguei em casa com um pouco de sangue no rosto. Minha mãe quis me proibir a brincadeira, mas 
eu consegui, depois de algum tempo, convencê-la a que eu voltasse ao jogo. Lá estava o meu adversário, que veio falar comigo gentilmente, e nós nos entendemos muito bem na meia língua inglesa que eu já falava. Voltando ao Rio, ao Colégio Rezende e às atividades familiares, recomecei minha vida com um certo orgulho de ter sido um visitante dos Estados Unidos. $\mathrm{Na}$ época, o importante era ir à Europa.

O Carnaval era, sem dúvida, um momento em que o divertimento tomava as rédeas. Bailes nos clubes, passeios na avenida e o corso no automóvel de minha tia Conceição Abranches ocupavam o meu tempo nos três dias de folguedo. Fora deles, eram as batalhas de confete realizadas, principalmente, na Zona Norte, sendo que uma delas, a da rua Dona Zulmira, era imperdível, como se diz hoje. Nessas "batalhas" fiz algumas amizades que perduraram durante muito tempo.

Um dia, em 1934, um colega meu de enfermaria, Aristides Paz de Almeida, convidou-me para participar do seu grupo no Carnaval. Era um grupo de quase vinte pessoas, distinguidas por uma grande águia pintada numa blusa azul. Achei muito feia a fantasia, mas não discuti, mesmo porque o meu automóvel era indispensável para transportar o pessoal de um lado para o outro. Fomos aqui, fomos ali, para terminar no Country Club, onde a festa chegava ao auge. Ao entrar, vi uma moça que achei linda e dispus-me a dançar com ela. Pedi ao rapaz que a acompanhava, meu colega Luiz Torres Barbosa, que me apresentasse a ela. Ele recusou-se e eu, perdendo a cerimônia, fui diretamente à menina e me apresentei, dizendo que eu sabia que meu pai era amigo do seu pai. Tratava-se de Annah. Dançamos um pouco, mas logo tive que seguir com o grupo, que foi comer ostras no mercado da Praça Quinze. Passei muito tempo sem vê-la, embora a procurasse nos lugares freqüentados pela sociedade do Rio, como a sessão das dez no Cinema Palace, às segundas-feiras, seguida de um sorvete na Americana, no andar térreo do Edifício Serrador. Só consegui reencontrá-la uma tarde, no Jockey Club, em um Grande Prêmio ganho pelo cavalo Tigipió, propriedade de um criador do Nordeste. Passei, então, a procurá-la no footing que, aos domingos, se fazia no calçadão da praia de Copacabana. Aí começamos a conversar, até que um dia vi uma linda senhora sentada num banco, olhando para nós com grande curiosidade. Tratava-se de Amelinha, irmã mais velha de Annah. Esta me levou à sua presença e à de seu marido, Múcio de Senna. 
Amelinha disse que não era conveniente que nós ficássemos conversando na praia e o melhor seria irmos à sua casa, o que fizemos subindo a rua Sá Ferreira até a Pompeu Loureiro, onde ela morava.

Minha segunda viagem ao exterior, quando já rapaz, foi ao Uruguai. Meu pai fora convidado a participar da X Conferência Pan-Americana, que se realizava em Montevidéu. A delegação brasileira, chefiada por Afrânio de Mello Franco, contava, entre outros membros, com Francisco Campos. Montevidéu é, sem dúvida, uma das cidades mais aprazíveis em que vivi. O mês que ali passei marcou profundamente, de um lado, a noção da importância da compreensão entre homens de diversas nacionalidades ou origens e, mais ainda, a minha vida sentimental. É que Annah acompanhara seu pai, e o nosso namoro, que começara no Country Club e se estendera ao footing dos domingos no agora chamado calçadão da avenida Atlântica, estabilizou-se, definitivamente, malgrado os "avisos" dados a seu pai por Afraninho, que também fazia parte da delegação, de que Afrânio deveria suspeitar de que a minha presença em Montevidéu trania resultados importantes. Afrânio de Mello Franco não quis tomar conhecimento das premonições dz família, e chegou a permitir que Annah, acompanhada de Dorinha, filha de Francisco Campos, fosse passar três dias em Buenos Aires com alguns amigos da delegação integrante, aos quais, mais do que rapidamente, eu me juntei.

Em Montevidéu, a vida de um adjunto sem responsabilidades face à delegação brasileira era a mais agradável possível. Festas, reuniões sociais e passeios com algumas personalidades unuguaias tornaram minha estada a mais útil, tanto mais que me aproximei muito do grupo de médicos que, ao lado de Clemente Estable, começavam a erigir o Instituto de Biologia. O ministro da Educação, Juanicó, homem de fina estrutura intelectual e moral, me mostrou como funcionava o sistema educacional uruguaio, extremamente avançado. Curiosamente, era ele parente de Annah, pois que também descendia do marechal Callado, que fora lutar para o estabelecimento do Uruguai e que se casara com uma uruguaia antepassada do ministro. Impressionou-me muito, em Montevidéu, o grau de escolarização das crianças e a superioridade do ensino secundário, quando comparado com o nosso, que, já nessa ocasião, apresentava sinais de decadência.

Bem mais tarde, fiz uma segunda viagem a Montevidéu, agora em missão oficial do Itamarati. Essa missão foi decorrente de um acordo entre os nossos 
governos, o qual determinava a ida a Montevidéu de dois brasileiros para professarem aulas ou conferências. Foi meu companheiro o professor Júlio Cesar de Mello e Souza, acompanhado de sua mulher. Eu também viajei com Annah. Seguimos de trem. Estafante percurso que me permitiu conhecer o interior gaúcho, pois a viagem pelo estado do Rio Grande do Sul foi feita, principalmente, de dia. Em Montevidéu fui extremamente bem acolhido pela comunidade científica. $R$. Talice havia realizado trabalhos significativos sobre a doença de Chagas e fez questão de me mostrar, detalhe por detalhe, o que tinha realizado. Da melhor qualidade. Annah e eu aproveitamos para voltar a Buenos Aires, onde ficamos dois ou três dias. Foi nessa ocasião que conheci, mais detalhadamente, um dos grandes cientistas jovens que encontrei na vida: Eduardo Braun Menendez. Trabalhava ele no Instituto de Fisiologia dirigido por Bernardo Houssay, uma das figuras singulares da comunidade científica latino-americana. Passei muitas horas conversando com Braun Menendez, que depois veio ao Rio para saber exatamente como se estava onganizando o Conselho Nacional de Pesquisas. Mais tarde, tive a felicidade de ter em meu laboratório seu filho Jorge Braun Cantilo, que defendeu tese de doutorado em medicina e viveu com a sua admirável mulher Inês, longo tempo, na rua Joaquim Nabuco, bem próximo da casa em que Annah e eu moramos até hoje.

Com a ajuda de primas de Annah e de amigos comuns, nosso namoro foi continuando e se firmando, até que um dia meu pai foi pedir, para mim, a mão de Annah em casamento. Alguns meses mais tarde este se realizou, no dia 6 de julho de 1935, na Igreja Nossa Senhora da Paz, com grande simplicidade, já que Amelinha e meu pai haviam falecido.

Sete anos depois, exatamente no dia 15 de agosto, nascia a primeira de minhas filhas: Maria da Glória, que recebeu esse nome por ser o dia de Nossa Senhora da Glória. Minha felicidade foi imensa. Quando ia para casa, encontrei-me com Manuel Bandeira na rua do Ouvidor, esquina com a travessa do mesmo nome. Perguntou-me o motivo da minha euforia. Conteithe do nascimento de Maria da Glória. Despedimo-nos e, ao chegar em casa, havia um recado para que lhe telefonasse. Assim o fiz. Disse-me Manuel que fizera para ela um poema: Maria da Glória: "Esta é Glória, esta é Maria"..., e assim por diante.

Dois anos mais tarde nascia Silvia Amélia: novo poema. Mais dois anos: Anna Margarida. Pedi ao Manuel que fizesse um poema, nele usando, também, 
o nome de Mariana. Por razões sentimentais disse-me que não poderia fazêlo. Escreveu, então, Anna Margarida. Eu acrescentei o Maria. Sete anos depois nascia a última de minhas "quatro filhas únicas", como costumo dizer. Falei com Manuel pedindo-lhe que lhe desse o nome: Cristina Isabel. $\mathrm{E}$ assim foi. Hoje, são quatro senhoras da mais alta qualidade, que me deram treze netos e, até agora, oito bisnetos.

Não posso deixar de acentuar a minha união com os irmãos e as irmãs de Annah, particularmente Virgílio, sem dúvida um dos varões mais ilustres e mais patrióticos que eu conheci. Dedicou toda a sua vida ao Brasil, mantendo-se sempre a distância de cargos e posições. A única que ocupou foi a de interventor no Banco Alemão, sem receber a menor retribuição financeira. Um dia, de madrugada, o telefone de minha casa tocou. Era Dulce, sua mulher, mais do que aflita, que pedia que eu fosse à sua casa, pois Virgílio fora covardemente assassinado, certamente por determinação de forças políticas que combatera impiedosamente.

Foi este um dos dois grandes choques que levei na vida. A morte de meu pai, embora súbita, era por assim dizer esperada. Nas vésperas, eu o acompanhara ao enterro de um dos seus colegas e colaboradores e ficara tão impressionado com a sua palidez que, ao chegar em casa, comuniquei a Evandro a minha preocupação. Combinamos levá-lo a um exame completo para saber exatamente o que tinha. Não conseguimos realizar o nosso intento, pois ele faleceu três dias depois. $\mathrm{O}$ outro choque foi a morte inesperada de Evandro. Tenho para mim que muitos dos nossos problemas sanitários estariam mais bem encaminhados se Evandro tivesse vivido mais tempo. Sua força de trabalho, sua inteligência e seu carisma eram a segurança de que muito ainda poderia ele fazer, além do que realizara. Evandro desapareceu aos trinta e cinco anos, como já disse, num desastre de um avião comercial em plena enseada de Botafogo, no momento em que ia visitar sua filha, em São Paulo.

Muito viajei, mas sempre a serviço, preocupado ao mesmo tempo em deixar o Instituto de Biofisica, que crescia, e Annah e as meninas, que nem sempre puderam me acompanhar. Nessas viagens fui sempre guiado pelo meu Bom Pastor, pois apenas uma vez tivemos um desastre de avião. Foi numa das ocasiões em que Annah e eu partimos de Roma em direção ao Rio. Contrariando o roteiro, o comandante resolveu tomar passageiros em Lisboa. Na hora de levantar vôo, estouraram os pneus do avião e o comandante 
foi obrigado a realizar a operação chamada "cavalo-de-pau", a cinqüienta metros do mar, sem poder impedir que numerosos pedaços de cimento da pista penetrassem na fuselagem, assustando todos os passageiros, entre os quais se encontrava o atual cardeal dom Lucas Moreira Neves. Não houve vítimas, mas os estragos no avião foram de tal ordem que a Varig foi forçada a requisitar, do Brasil, um outro avião. Em conseqüência, ficamos um dia e meio num hotel muito confortável, no Estoril, o que nos permitiu fazer um longo passeio por Lisboa, o que é sempre muito agradável.

$\mathrm{Na}$ verdade, sempre que pude passei por Paris. Várias vezes ali estive por maiores temporadas. Assim, quando fui dar um curso sobre tecidos excitáveis, na Sorbonne, ou quando, em outra ocasião, dei aulas sobre historradiografia, técnica que eu havia aprendido com a pesquisadora belga A. Ficq. Meu grande patrono em Paris foi Pasteur Vallery-Radot, neto do grande Pasteur. Foi ele me ver na primeira viagem que fiz depois da última guerra, no Hotel Lutetia, um dos poucos que podiam receber estrangeiros, pois tinha aquecimento. $O$ frio era intenso em Paris e a faculdade de obter bens de consumo era muito restrita. Annah e eu, que fomos de navio, tínhamos levado uma enorme mala cheia de mantimentos, os quais rapidamente distribuímos aos amigos mais caros. Aqueles que possuíam propriedade no campo ainda tinham um pouco de fartura. Entretanto, faziam questão de nos receber em casa, numa hospitalidade que não se pode descrever. Eram todos grandes nomes da ciência, particularmente da medicina, que tinham conhecido meu pai, do qual com frequiência lembravam os trabalhos, a ação sanitária, e até mesmo as distrações que cometia no cotidiano. Nessa viagem resolvi defender tese de doutorado em ciências, o chamado "doutorado da universidade", que não exige os quatro anos para a tese de docteur en sciences. No dia da minha defesa, na Sorbonne, o frio era intensíssimo, e tanto eu quanto os meus examinadores não pudemos dispensar os pesados sobretudos que usávamos. Não havia calefação e a temperatura na rua era de $-22^{\circ} \mathrm{C}$. Livrei-me, assim, de uma obsessão, que era a de praticar ciência sem ter um título condizente.

Pasteur Vallery-Radot vinha freqüentemente me ver. Levou-me, várias vezes, ao seu serviço no Hospital Broussais, admiravelmente instalado, no qual pronunciei duas conferências. Além do mais, fui com ele à Academia de Medicina de Paris, da qual me fez membro associado, grau acima do de membro correspondente. Convidou-me, com freqüência, para almoços e 
jantares em sua casa, e ali conheci eminentes figuras do cenário cultural francês, muitas das quais membros da Académie Française, da qual Vallery-Radot fazia parte. Entre eles, Paul Claudel.

Outro anfitrião extraordinário foi o diretor do Instituto Pasteur, Jacques Tréfouel. Entre as variadas oportunidades que Thérèze e Jacques nos proporcionaram para melhor conhecer Paris, das mais interessantes foi um jantar em sua casa, com Sacha Guitry. Contou-nos ele a sua vida e episódios interessantíssimos de sua carreira. Fez-nos rir e chorar, pois, grande artista que era, introduzia em todas as suas descrições uma extraordinária mímica. 


\section{X}

\section{Concentração, alegria e otimismo}

D ara a formação do Instituto de Biofísica, tive, sem dúvida, auxílios de toda a parte. Quero, inicialmente, assinalar o de Annah, que compreendeu a minha vocação. Desejo, também, enfatizar que, sem a ajuda de Guilherme Guinle nada teria sido feito. Do mesmo modo, o auxílio que me deu o reitor Pedro Calmon e vários companheiros da universidade, como Paulo de Góes, Raymundo Moniz de Aragão e Deolindo Couto. Quero me referir, também, a três funcionários que exerciam funções mais simples, mas que muito me ajudaram: Augusto da Silva, primeiro servente do Instituto de Biofisica, Wilton Batista de Paula e Raquel Ribeiro dos Reis Soares. Assinalo, ainda, que sem a colaboração de Ana Maria Leão Teixeira eu não poderia ter organizado o instituto.

Minha contribuição foi a de realizar um grande esforço baseado em que nada se pode fazer sem concentração, alegria e otimismo. Esta, aliás, é a maneira pela qual um pesquisador deve se conduzir. A concentração significa ter fixado na cabeça o problema de maior ou menor relevância do momento. Para isso, o tempo integral é indispensável. Por isso mesmo me recusei a assumir vários postos simultaneamente à cátedra universitária. Do mesmo modo, só se realiza um trabalho que tenha em si um componente lúdico. O otimismo é necessário pelas contrariedades que qualquer atividade pode apresentar, ainda mais em um país em que a atividade científica é tão mal compreendida, mesmo que objeto de uma falsa apreciação. 
Ser-me-ia impossivel descrever toda a atividade dos meus companheiros do Instituto de Biofisica, alguns citados neste texto. Foram sua solidariedade e compreensão que me levaram a realizar o que pude fazer. A atividade do instituto pode ser traduzida nos mais de mil duzentos e trinta trabalhos publicados, nas quase oitocentas teses realizadas e no pesado trabalho de ensino de graduação, pós-graduação e iniciação científica, que fazem com que passem pelas nossas salas de aula e laboratórios mais de quatro mil e quinhentos alunos por ano, já que o instituto é encarregado do ensino das disciplinas de fisiologia e biofisica para todos os cursos que as tenham no seu currículo, como medicina, farmácia, odontologia, biologia, psicologia, educacão fisica, nutrição e enfermagem.

Creio que o objetivo que eu tinha quando solicitei a Leitão da Cunha a criação do Instituto de Biofísica, seja o de associar o ensino à pesquisa, já que essa combinação é o que caracteriza uma universidade, como bem assinalou o cardeal Newman, foi alcançado. De mim, sei que fiz o que pude e que a minha carreira científica foi sacrificada, em parte, pelas atividades que exerci fora do Brasil. Disto não me arrependo, pois de cada uma delas pude trazer alguma coisa de fertilizante para o nosso grupo. Destaco na minha atividade somente a demonstração da molecularidade de um receptor de färmacos, no caso o receptor colinérgico, encontrado no órgão elétrico do Electrophorus electricus (L.) e observado graças à utilização de um curare radioativo preparado, inicialmente, no Instituto Pasteur de Paris, com a colaboração de Jacques Tréfouel e Gérard Milhaud e, posteriormente, depois de lhe ter fornecido a técnica de obtenção, comercializado pela Nuclear Chicago Company.

Se os resultados da minha carreira científica não foram o que eu desejava, a alegria que ela me trouxe, tão bem acompanhado que fui por minha mulher e minhas filhas e genros, amparado, ainda, pela amizade dos meus colegas de instituto e de universidade, sem dúvida preencheu minha vida.

E agora? Pretendo continuar no mesmo ritmo que caracterizou a minha vida, tendo, como objetivo, o avanço do conhecimento científico em nosso país, com os olhos sempre voltados para a melhoria das condições de vida de todos aqueles que nele vivem.

Termino fazendo próprias as palavras de René Wurmser, numa carta em que me escreve, aos cento e um anos de idade: 
Concentração, alegria e otimismo

Je m'étonne moi même de conserver, malgré tout, tant de curiosité pour ce qui se passe dans le monde et plus encore pour cette diablesse de biophysique, tourment et enchantement de ma vie.*

* Espanto-me de conservar, apesar de tudo, tanta curiosidade pelo que se passa no mundo e mais ainda por esta diaba de biofísica, tormento e encantamento de minha vida. 

Anexos 



\title{
Declaration on Prevention of Nuclear War
}

\author{
I
}

Throughout its history, humankind has been confronted with war, but since 1945 the nature of warfare has changed so profoundly that the future of the human race, of generations yet unborn is imperiled. At the same time, mutual contacts and means of understanding between peoples of the world have been increasing. This is why the yearning for peace is now stronger than ever. Mankind is confronted today with a threat unprecedented in history, arising from the massive and competitive accumulation of nuclear weapons. The existing arsenals, if employed in a major war, could result in the immediate deaths of many hundreds of millions of people, and of untold millions more later through a variety of aftereffects. For the first time, it is possible to cause damage on such a catastrophic scale as to wipe out a large part of civilization and to endanger its very survival. The large-scale use of such weapons could trigger major and irreversible ecological and genetic changes, whose limits cannot be predicted.

Science can offer the world no real defense against the consequences of nuclear war. There is no prospect of making defenses sufficiently effective to protect cities since even a single penetrating nuclear weapon can cause massive destruction. There is no prospect that the mass of the population could be protected against a major nuclear attack or that devastation of the

\footnotetext{
* Texto apresentado ao papa João Paulo II por uma assembléia de trinta e cinco presidentes de academias científicas e outros cientistas de todo o mundo. (N.E.)
} 
cultural, economic and industrial base of society could be prevented. The breakdown of social organization, and the magnitude of casualties, will be so large that no medical system can be expected to cope with more than a minute fraction of the victims.

There are now some 50,000 nuclear weapons, some of which have yields a thousand times greater than the bomb that destroyed Hiroshima. The total explosive content of these weapons is equivalent to a million Hiroshima bombs, which corresponds to a yields of some three tons of TNT for every person on earth. Yet these stockpiles continue to grow. Moreover, we face the increasing danger that many additional countries will acquire nuclear weapons or develop the capability of producing them.

There is today an almost continuous range of explosive power from the smallest battlefield nuclear weapons to the most destructive megaton warhead. Nuclear weapons are regarded not only as a deterrent, but there are plans for their tactical use and use in a general war under so-called controlled conditions. The immense and increasing stockpiles of nuclear weapons, and their broad dispersal in the armed forces, increase the probability of their being used through accident or miscalculation in times or heightened political or military tension. The risk is very great that any utilization of nuclear weapons, however limited, would escalate to general nuclear war.

The world situation has deteriorated. Mistrust and suspicion between nations have grown. There is a breakdown of serious dialogue between the East and West and between North and South. Serious inequities among nations and within nations, shortsighted national or partisan ambitions, and lust for power are the seeds of conflict which may lead to general and nuclear warfare. The scandal of poverty, hunger, and degradation is in itself becoming an increasing threat to peace. There appears to be a growing fatalistic acceptance that war is inevitable and that wars will be fought with nuclear weapons. In any such war there will be no winners.

Not only the potentialities of nuclear weapons, but also those of chemical, biological and even conventional weapons are increasing by the steady accumulation of new knowledge. It is therefore to be expected that also the means of non-nuclear war, as horrible as they already are, will become more destructive if nothing is done to prevent it. Human wisdom, however, 
remains comparatively limited, in dramatic contrast with the apparently inexorable growth of the power of destruction. It is the duty of scientists to help prevent the perversion of their achievement and to stress that the future of mankind depends upon the acceptance by all nations of moral principles transcending all other considerations. Recognizing the natural rights of humans to survive and to live in dignity, science must be used to assist humankind towards a life of fulfillment and peace.

Considering these overwhelming dangers that confront all of us, it is the duty of every person of good will to face this threat. All disputes that we are concemed with today, including political, economic, ideological and religious ones, which are not to be undervalued, seem to lose their urgency compared to the hazards of nuclear war. It is imperative to reduce distrust and to increase hope and confidence through a succession of steps to curb the development, production, testing and deployment of nuclear weapons systems, and to reduce them to substantially lower levels with the ultimate hope of their complete elimination.

To avoid wars and achieve a meaningful peace, not only the powers or intelligence are needed, but also the powers of ethics, morality and conviction.

The catastrophe of nuclear war can and must be prevented. Leaders and governments have a grave responsibility to fulfill in this regard. But it is humankind as a whole which must act for its survival. This is the greatest moral issue that humanity has ever faced, and there is no time to be lost.

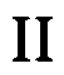

In view of these threats of global nuclear catastrophe, we declare:

1) Nuclear weapons are fundamentally different from conventional weapons. They must not be regarded as acceptable instruments of warfare. Nuclear warfare would be a crime against humanity.

2) It is of utmost importance that there be no armed conflict between nuclear powers because of the danger that nuclear weapons would be used.

3) The use of force anywhere as a method of settling international conflicts entails the risk of military confrontation of nuclear powers. 
4) The proliferation of nuclear weapons to additional countries seriously increases the risk of nuclear war and could lead to nuclear terrorism.

5) The current arms race increases the risk of nuclear war. The race must be stopped, the development of new more destructive weapons must be curbed, and nuclear forces must be reduced, with the ultimate goal of complete disarmament. The sole purpose of nuclear weapons, as long as they exist, must be to deter nuclear war.

\section{III}

Recognizing that excessive conventional forces increase mistrust and could lead to confrontation with the risk of nuclear war, and that all differences and territorial disputes should be resolved by negotiation, arbitration or other peaceful means, we call upon all nations:

1) Never to be the first to use nuclear weapons.

2) To seek termination of hostilities immediately in the appalling event that nuclear weapons are ever used.

3) To abide by the principle that force or the threat of force will not be used against the territorial integrity or political independence of another State.

4) To renew and increase efforts to reach verifiable agreements curbing the arms race and reducing the numbers of nuclear weapons and delivery systems. These agreements should be monitored by the most effective technical means. Political differences or territorial disputes must not be allowed to interfere with this objective.

5) To find more effective ways and means to prevent the further proliferation of nuclear weapons. The nuclear powers, and in particular the superpowers, have a special obligation to set an example in reducing armaments and to create a climate conducive to non-proliferation. Moreover, all nations have the duty to prevent the diversion of peaceful uses of nuclear energy to the proliferation of nuclear weapons.

6) To take all practical measures that reduces the possibility of nuclear war by accident, miscalculation or irrational action.

7) To continue to observe existing arms limitation agreements while seeking to negotiate broader and more effective agreements. 


\section{IV}

Finally, we appeal:

1) To national leaders, to take the initiative in seeking steps to reduce the risk of nuclear war, looking beyond narrow concerns for national advantage: and to eschew military conflict as a means of resolving disputes.

2) To scientists, to use their creativity for the betterment of human life, and to apply their ingenuity in exploring means of avoiding nuclear war and developing practical methods of arms control.

3) To religious leaders and other custodians of moral principles, to proclaim forcefully and persistently the grave human issues at stake so that these are fully understood and appreciated by society.

4) To people everywhere, to reaffirm their faith in the destiny of humankind, to insist that the avoidance of war is a common responsibility, to combat the belief that nuclear conflict is unavoidable, and to labor unceasingly towards ensuring the future of generations to come. 

Senhoras e Senhores: ${ }^{\star}$

Penhoradíssimo agradeço esta homenagem que me prestam meus companheiros da comunidade científica brasileira.

Sei que ela é a conseqüência da generosidade daqueles que, como eu mesmo, nada mais fazem do que se empenhar na certeza do ideal de dar ao Brasil uma base científica e tecnológica capaz de facilitar a vida de todos aqueles que vivem em nosso querido Brasil.

Devo agradecer especialmente à Faperj e à minha querida Academia Brasileira de Ciências. Ainda que os achaques de uma longa vida derrubem uma grande parte da nossa memória, ouso, entretanto, me aventurar a assinalar que cabe-me um pouco na criação das Fundações Estaduais de Pesquisa.

É que, em certa ocasião, trabalhava eu na preparação de uma tese no laboratório da Praia Vermelha com o deputado Rui Santos, digno representante da Bahia. Sugeri-lhe que apresentasse um projeto pelo qual os estados criassem um sistema próprio de fomento à pesquisa.

Penso ter sido esta a oportunidade para que os membros da Federação desenvolvessem os sistemas das fundações de amparo que nobilitam as atividades de pesquisas e em certos estados, como no estado de São Paulo, superam em muito as dotações federais ou municipais. No estado do Rio de Janeiro, hoje eminentemente dirigido pelo governador Anthony Garotinho, o mesmo vai acontecer dentro de pouco tempo.

* Último texto escrito pelo professor Carlos Chagas Filho, agradecendo a concessão do Prêmio Faperj, conferido pelo Governo do Estado do Rio de Janeiro. Apesar de Carlos Chagas Filho estar presente à solenidade, esta declaração não chegou a ser pronunciada, sendo aqui publicada pela primeira vez. (N.E.) 
Quanto à Academia Brasileira de Ciências, tem sido ela uma das minhas preocupações constantes, desde o tempo em que nós nos reuníamos após as sessões que se realizavam no edificio da Escola de Politécnica, pois não tínhamos sede ainda, e tomávamos um pequeno drink na cervejaria que havia no andar térreo do edifício do Hotel Avenida.

Não éramos muitos, mas entre nós estavam Arthur Moses, que veio presidi-la com a maior dignidade durante anos, Álvaro Alberto, que logo depois ajudou o Brasil a criar o seu Conselho Nacional de Pesquisas, Dulcídio Pereira, Francisco Venâncio, Carneiro Felipe e outros.

Tive a honra de ser presidente da Academia Brasileira de Ciências por um certo prazo, já que o presidente Castelo Branco me convocou para substituir o insubstituível Paulo Carneiro na direção da Embaixada do Brasil junto à Unesco. Pouco pude fazer neste período pela Instituição, mas consegui, através da Presidência da República e do ministro Roberto Campos, uma lei especial que durante a sua vigência levou aos cofres da Academia um apreciável montante.

No terreno da pesquisa segui uma filosofia que me parece importante para países como o nosso. Creio que consegui, pelo menos em grande parte, realizar o que queria: associar a pesquisa ao ensino, o que dobra o valimento deste.

Porém não me considero de forma alguma, nem mesmo com a recompensa que hoje me é dada, uma pessoa realizada, o que explica o título de meu livro de memórias Um aprendiz de ciência.

Não teria sido melhor eu ter me ocupado dos pobres que vi no meu caminho, das almas preocupadas que cruzaram a minha vida, aquelas que eu vi na penúria em Lassance, ou com quem me encontrei num ambulatório do Hospital Oswaldo Cruz, hoje Hospital Evandro Chagas?

É uma questão que paira na minha consciência e que eu não sei responder, embora uma manifestação como a de hoje me faça crer que eu não tenha sido inútil para o Brasil.

Obrigado,

Carlos Chagas Filho

Rio de Janeiro, 21 de dezembro de 1999. 


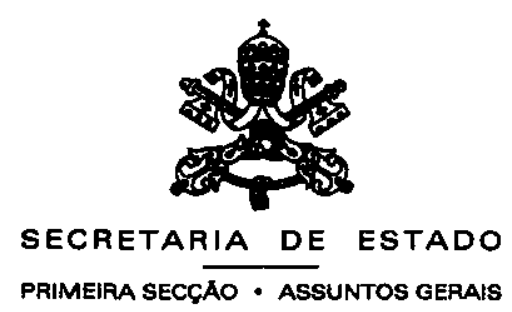

Vaticano, 18 de fevereiro de 2000.

\title{
Excelência Reverendíssima
}

Ao tomar conhecimento do falecimento do Prof. Carlos Chagas Filho, o Santo Padre encareceu-me fazer chegar aos familiares e amigos Sua expressão de pêsames abaixo transcrita:

\author{
"Exma. Sra. \\ Viúva do Prof. Carlos Chagas Filho \\ Rio de Janeiro (RJ)
}

Foi com profundo pesar que recebi a notícia do falecimento do Professor Carlos Chagas Filho. Este ilustre filho da nação brasileira, que como cristão exemplar e bondoso pai de família, será recordado pela sua generosa e abnegada dedicação como Presidente da Pontifícia Academia das Ciências, graças a qual a Igreja se tornou mais presente no mundo da ciência, pelos seus méritos de prestigiososo pesquisador, foi chamado à Casa do Pai. Em espírito de filial resignação aos desíginios da Divina Providência, desejo compartilhar com a dor dos seus familiares e amigos de todo o Brasil, e elevo ao Todo Poderoso ardentes preces em sufrágio da sua alma para que, à luz da gozosa esperança da ressurreição, o Senhor o acolha para sempre no Seu Reino de Paz e de Amor. Ao formular-lhe minhas mais sinceras condolências envio com afeto uma confortadora Benção Apostólica, extensiva aos seus familiares.

JOANNES PAULUS PP. II" 



\section{Índice onomástico}

A

Abranches, Conceição 191

Adisheshiah, Malcom 160

Adler, Salomão 90

Adrian, Edgard 84, 85, 134

Agassiz, Louis 36

Aguiar, Souza, marechal 19

Albe-Fessard, Denise 80, 134

Alberto (da Motta e Silva), Álvaro $99,117,146-148,171,187$

Albuquerque, Edson Xavier de 130

Albuquerque, José Joaquim da Costa

Medeiros de 46

Alencar, Cristóvão de 46

Almeida, Álvaro Ozorio de 48, 49, 76

Almeida, Aristides Paz de 191

Almeida, Darcy Fontoura de 18, 161

Almeida, José Carlos Cabral de 111, 131

Almeida, Miguel Ozorio de 35,

$48-50,58,71,73,75$,

$78,79,171$

Alves, Francisco de Paula Rodrigues 80

Amado, Gildázio 186

Andrade, Joaquim Pedro de 131

Antici, Maria da Glória Chagas

151, 193
Antipoff, Helena 167

Antônio 22

Antunes, Augusto Trajano de Azevedo 108

Aquino, Tomás de, santo 70

Aragão, Henrique de Beaurepaire Rohan 46

Aragào, Raimundo Moniz de $113,140,197$

Aranha, Temistocles da Graça 146

Arrhenius, Svante 55

Ataíde, Austregésilo de 186

Ataíde, Tristão de (pseud. de Alceu

Amoroso Lima) 135, 175, 176, 185

Audifret 24

Auger, Daniel 80, 96

Auger, Pierre 156

Avelar, Raul 38

Azevedo, Marinho de 74

B

Bacq, Zenon 149

Ballestrero, cardeal 182

Bandeira, Manuel 74, 167, 193, 194

Banting, Frederick 190 
Barbosa, Luiz Torres 191

Barcinski, Marcello 111

Baring, Maurice 53

Barrault, Jean-Louis 55, 82

Barreto, Mena 65

Baruch, B. 95

Bastos, Werther Duque Estrada 17, 109

Benedito XV, papa 179

Benelli, cardeal 174, 175

Berle, Adolf 151

Berle, Beatriz 151

Bernanos, Georges

$41,53,70,105$, $120,121,159,176$

Bernardes, Artur 67

Bertrand, Gabriel 136

Best, Charles 190

Biard, F. 42

Bizet, Georges 54

Bordet, Jules 46

Bovet, Anna Margarida Chagas 18

Bovet, Daniel 110, 115, 116, 135

Bovet-Nitti, Filomena 115, 135, 153

Braga, Belmiro 37

Braga, Ernani de Almeida 157

Braga, Teófilo 9

Brailowsky, Alexander 54

Braun Menendez, Eduardo 193

Broglie, Louis de 11

Broglie, Maurice de (duque de Broglie) 11

Bronk, Detlev 115

Brown, Alfred 113

Bueno, Américo Galvão 176

Bures, Jan 102, 103

Bustamante, Emília 139

Buzzatti-Traverso, Adriano 161
C

Caburé 38, 40

Caldas, Luiz Renato C. da Silva 98, 111, 181

Caldas, Sílvio 46, 54

Callado, Crisóstomo (marechal de campo) 192

Calmon, Pedro 113, 141, 143, 197

Campos, Dora 77, 192

Campos, Francisco 192

Campos, Roberto 158

Candau, Marcolino Gomes 157

Cantillo, Inês 193

Cantillo, Jorge Braun 114, 193

Canuto, Vittorio 182

Capanema, Gustavo 119, 145

Cardim, Elmano 186

Carmo, Lêda Serrano do 18

Carmo, Romualdo José do 102, 103

Carneiro, Américo Piquet 142

Carneiro, Aurora Lôbo 23

Carneiro, Otávio Barbosa 23, 24, 25

Carneiro, Paulo 11, 31, $136,157,158,159$

Carneiro, Trajano 158

Carrel, Alexis 190

Carvalho, Antônio Paes de 108, 140

Carvalho, Horácio de 26

Carvalho, José Cândido de 186

Carvalho, Paulo de 75

Castello Branco, Humberto de Alencar $139,157,158,172$

Castro, Almir 32, 70, 74, 87

Castro, Aloysio de 86

Castro, Firmino Torres de 131

Castro, Francisca Vivas de 28 
Castro, Francisco de Oliveira 74

Castro, Gilberto Mendes de Oliveira 130

Castro, Gustavo de Oliveira 57, 102, 147

Castro, Hennique Ribeiro de $28,29,175$

Castro, Jacy Faro de 131

Castro, Leopoldo Ribeiro de 29

Castro, Leopoldo Vivas de 29

Castro, Max Vivas de 29

Cavalcanti, Leny 129

Caymmi, Dorival 77

Cesi, Federico (duque de Acquasparta) 178,179

Chagas, Anna Leopoldina de Mello

Franco, (dita Annah) 17, 28,

$29,30,77,82$,

$85,89,152,175,189$,

191-195, 197

Chagas, Carlos Ribeiro Justiniano

$11,29,31,33,35,37,38,43$, $48,50,62,66,67,187$

Chagas, Evandro Serafim Lobo

$20,43,68,70,75,88-92$,

$103,118,119,189,194$

Chagas, Mariana Cândida de Castro $28,29,36,175$

Champlinska 26

Clark, A.J. 110

Claudel, Paul 55, 196

Coats, C.W. 101

Colman, Ronald 38

Comte, Auguste 160

Cooper, J.D. 108, 131

Corção, Gustavo 134, 135
Cordeiro, A. 130

Costa, Celestino da 187

Costa, Fernando 95

Costa, Fonseca 59

Costa, Manuel Amoroso 49

Costa, Virgílio 140

Costa, filho, Odilo 70

Couceiro, Antônio Moreira $91,108,109,126,128,147$

Couto, Deolindo 197

Couto, Miguel 185

Couty, Louis 48, 136

Cox, R.T. 101

Crick, Francis 135

Cruz, Eduardo Oswaldo 102, 129

Cruz, José da Costa 35, 46-48, 58

Cruz, Oswaldo Gonçalves 24, 33 , $51,55,60,61,80,97,172,174$

Cruz, Walter Oswaldo 32, 33, $34,64,172-174$

Cunha, Aristides Marques da 57

Cunha, Raul Leitão da 63, 71, $75,85,93,100,198$

Curie, Jolliot 108

Curie, Marie 79

D

Dario, Ruben 55

Dauberson, Dany 82

De Duve, Christian 181

De Gaulle, Charles 97, 105

Deane, Leonidas de Mello 91

Deane, Maria José von Paumgarten 91

Dias, Emmanuel 32-34, 38, 45, 119

Dias, Ezequiel Campos 33 
Dias, Mário Viana 50

Dieuzaide, L. 95

Dingues, Elza (dita Fräulein)

$20-23,175,189$

Diomedes 20, 21

Donnan, Frederick 83

Dostoievski, Fiodor 121

Druon, Maurice 11

Duarte, Maurício 36, 38

Düerck, Hermann 97

Durtain, Luc 11

E

Eccles, John Carew 114, 135, 136

Eichner, Eric 74

Einstein, Albert 183

Eisenbud, Merril 130

Elmandjrá 166

Emptine, Yves de 169

Erven, Mário van 21

Estable, Clemente 192

Evans, Robley 107

F

Fabre, René 129

Faria, Carlos Alberto Rocha 21, 22

Faria, José Gomes de 59

Faria, Otávio 20

Faulkner, William 121

Fauré-Fremiet 38

Feio, Carlos 87

Felippe, José Carneiro 18, 50-52, $55,58,60,71,75,147$
Fermi, Enrico 48, 82

Ferreira, Hiss Martins 102, 109

Ferreira, Procópio 54

Fessard, Alfred 80, 81, 96, 134

Fialho, Branca de Almeida 49, 69, 73

Ficq, A. 195

Figueiredo, Carlos Burle de 36, 46, 64

Figueiredo, Jackson de 175

Fioravanti, Ruy 25

Fischer, Albert 88

Fischer, Ronald 85

Fleta, Miguel 53

Florkin, Marcel 135, 187

Fonseca, Deodoro da 80

Fonseca Filho, Olímpio da 173

Fonseca, Fróes da 75, 139

Fontes, Antônio Cardoso 92, 119, 174

Fraga, Filho, Clementino 140

Franca, Eduardo Penna 108, 125,

c126, 130, 131, 181

Franco, Afonso Arinos de Mello 146,168

Franco, Afrânio de Mello

$66,70,77,78,82,176,192$

Franco, Fernando Buarque 151

Franco Filho, Afrânio de Mello 77, 192

Franco, Virgílio de Mello 70, 120, 194

Freire, Gilberto 186

Freitas, Gilberto de 35

Freitas, Haroldo de 32

Freitas, João Ferreira Teixeira de 57

Freud, Sigmund 47, 69

Frey-Wissing, A. 135

Fróes, Leopoldo 54

Frontin, Paulo de 64 
Gadelha, Paulo 18

Gaffré, Cândido 48

Galileu (Galileo Galilei, dito) 183

Galvão, Paulo 49

Gama, Paulo 25

Gattass, Ricardo 129

Gemelli, Agostino, padre 178, 179

Giemsa, G. 97

Godoy, Alcides 55, 56

Godoy, Armando 175

Góes, Paulo de 113, 197

Goethe, Johann Wolfgang von 23

Gonçalves, José Moura

$17,86,87,94,108,133$

Gorbachev, Mikhail 181

Gorceix, Henri Claude 51

Goulart, Joâo (Belchior Marques) 139

Gouvêia Vieira, Cristina Izabel Chagas 194

Gove, Harry E. 182, 183

Green, Julian 53, 121

Greenstein, Jesse 132

Griffith, David 20

Grimaldi, Júlio 62

Guerra, Salles 35

Guggenheim, Eugene 75, 83

Guimarães, Felipe Nery 91

Guimarães, Luis Pinheiro 76

Guimarães, Ugo Pinheiro 157

Guinle, Guilherme 17, 88, 89, 92 , 106, 118, 119, 134, 197

Guitry, Sacha 196

Guzmán-Barron, E. 126
Haldane, John Burdon 79, 148

Hargreaves, Alberto Barbosa $109,126,133$

Hargreaves, Fernando Barbosa 133

Hartmann, Max 97

Harvey, Newton 95, 115

Hawking, Stephen W. 184

Hérelle, Félix-Hubert d' 47, 81

Hernandez-Morán 133, 135

Hesse, Hermann 53

Hiatt, Howard 181

Hill, Archibald V. 62, 83

Hitler, Adolf 84, 106, 124, 185

Hoff, Jacobus van't 55

Hoffman, Brian 102

Horta, Almada 37

Horwitz, Abraão 156

Houssay, Bemardo 156, 193

Humboldt, A. von 136

Huxley, A. 134

I

Impossíveis, Maria dos 38, 39

Itararé, barão de (Apparicio Torelly, dito Apporelly) 65

J

Jacob, François 98

Jacobina, Antônio Ferreira 21

João IV, rei de Portugal 9

João Paulo II, papa (Karol Wojtyla) $181,182-184$ 
João XXIII, papa (Angelo Giuseppe

Roncalli) 177

José (dito Sinhô José) 42

Jourdan, Michel 143

Jouvet, Louis 54

Joxe, Louis 96, 159

Juanicó 192

K

Katchalsky, Ephraim 115

Katzin, A.G 152

Kennedy, John Fitzgerald 117

Keynes, Richard 109, 134, 136

Kitttani, Ismat 181

Kofoid 124

Kölbe, Maximiliano 184, 185

Konder, Valério 89

König, cardeal 183

L

Laberye 168

Laboriau, Fernando 49

Lacaz, Paulo 88

Lacerda, Benedito 46

Lacerda, João Batista de 48, 136

Lacerda, Maurício de 64

Lacorte, José Guilherme 33

Ladous, Régis 178

Lafayette (Rodrigues Pereira), Francisco $71-73,75,86,87$

Lage, Gabriella Besanzoni 54

Langevin, P. 79

Lapicque, Louis 127
Latarjet, Raymond 98

Lattes, Cesar 107

Laugier, Henri 151

Leão, Aristides Azevedo Pacheco $88,95,102,103,118,174$

Leão, Pacheco 32

Leitão, Aluisio de Mello 118

Lejeune, Jerôme 177, 181, 184

Léman, Rosamund 53

Leme, cardeal 66

Lent, Herman 57, 173

Lent, Roberto 129

Leprince-Ringuet, Louis 181

Levi, Giuseppe 124, 125

Levi-Montalcini, Rita 124, 125, 17 :

Lima, Alceu Amoroso ver Ataíde, Tristão de

Lima, Ângelo Moreira da Costa $56,58,59$

Lima, Carlos Cruz 140

Lima, Francisco Negrão de 141

Linden, Raphael 129

Lineu, Carl von 96

Lipmann, Fritz 97

Lobo, Fernando 20, 54

Lobo, Fernando Gusmão 26

Lobo, Hélio 70, 190

Lobo, Luis Carlos Galvão

95, 112,136, 140, 142

Lobo, Maria 20, 53, 70, 105

Londres, Genival 36, 43

Lopes, Hugo Souza 57

Lopes, José Leme 158

Lopes, Luiz Simões

67, 86, 92, 99, 117, 119, 186

Lopes, Tito Enéas Leme

$33,70,76,86,87,94,132$ 
Luís, Washington $53,64,65,66$

Lutz, Adolpho 58, 61

Lwoff, André 81, 98

M

Machado, Astrogildo

$24,55,56,58,88$

Machado, Francisco Eduardo de Paula 129

Machado, Irineu 64

Machado, João C. 88,124

Machado, Raul Dodsworth

$114,133,136$

Magalhães, José 31, 32

Maheu, René 160, 161, 162

Maiman, Bernardo 96

Mangabeira, Otávio 65

Mann, Thomas 53

Marchoux, Émile 80, 81

Marini-Bettòlo, Giovanni Battista 181

Mário Filho 139

Maritain, Jacques 159

Marshall, Wade 102

Martini, cardeal 183

Mascarenhas, Hildefonso 186

Mathews, Brian 134

Mauriac, François 53, 121

Medeiros, Trajano de 24

Meira, Sérgio 67

Meirelles, Alberto Soares de 143

Mello, Antônio Silva 49, 168, 186

Mello Franco, Dulce Boavista de 194

Mello Franco, Gemina Pereira de

77,82

Mello, Walmor Carlos de 108
Melo, Francisco Manoel de, dom 9

Memória, Tatiana Chagas 89

Mendes, Raimundo Teixeira 23

Mendonça, Ana Amélia de Queiróz Carneiro de 186

Mendonça, Maria José Carneiro de 186

Menon, G.K. 156

Metchinikov, Ilya 81

Meyer, Hertha 88, 103, 104, 106, $109,114,124,125,133$

Meyerhoff, Otto 79

Milhaud, Gérard 198

Mineur, Gabrielle 96

Minote (dita dona Minote) 22

Minstingue (Jeanne Bourgeois, dita) 82

Miranda, Carlos Eduardo Rocha 102, 129

Miranda, Maury 97, 109, $118,126,131$

Mitterrand, François 181

Molière (Jean-Baptiste Poquelin, dito) 9

Monier, A. 146

Monod, Jacques 98

Montherlant, Henry Millon de 82

Moraes, Vinicius de 20, 74

Moreira, José da Frota 74

Moreira, Manoel da Frota $109,123,126,132$

Moreira, Oromar 86, 94

Mortara, Giorgio 87

Moscoso, Marina 25

Moses, Arthur 171, 172

Moura, Chagas 175

Moura Neto, Vivaldo 128

Mourão, Aureliano, monsenhor 28

Moussatché, Haiti 34, 50

Muniz, Júlio 58 
Mussolini, Benito 68, 81, 176, 179

Muzio, Claudia 53

$\mathrm{N}$

Nachmanson, David 101, 115, 136

Nava, Pedro 33, 75

Nehru, Jawaharlal 167

Nervo, Amado 55

Neves, Lucas Moreira, cardeal 195

Newman, cardeal 198

Nica 25

Nicholson, Charles 102

Niemeyer 25

Novelli, Luís 69

O

Occhialini, Giuseppe 20, 106, 107

Ochoa, Severo 114, 135, 180, 181

Oliveira, Mécia Maria de 128

Oliveira Neto, Joaquim de 33

Oliveira, Sebastião José de 57

Oppenheimer, J. 155

Ostwald, Wilhelm 55

Overmeer, Assueros 60, 61

Ozeray, Madeleine 55

$\mathbf{P}$

Palamoni 24

Palmério, Mário 186

Pamplona, Artidonio 43

Paraense, Wladimir Lobato 91, 119
Pasteur, Louis 80, 81, 195

Paula, Wilton Batista de 112, 197

Pauling, Linus 149, 150

Paulo VI, papa (Giovanni Battista Montini) 174-179, 183-185

Pavan, Crodowaldo 130, 150

Pedro II, imperador do Brasil 81

Pedro, João 32

Peixoto, Afrânio 185

Pena, Osvino Álvares 36, 46, 63, 187

Pende, Nicola 68, 81

Penido, João Carlos Nogueira 56

Penna, Augusto de Oliveira Belisário 175

Penna, Henrique de Azevedo 36, 46

Pereira, Álvaro Lobo Leite 33, 34

Pereira, Álvaro Nunes 21

Pereira, Higas Chagas 26

Pereira, Lafayette Rodrigues 76

Pereira, Odette Rodrigues 72

Pérrin, Jean 145

Perutz, Max 181

Pétain, Philippe 120, 121

Pfeiffer, Wolfgang 126

Piaf, Edith 82

Piéron, Henri 78, 79

Pimenta, Alexandre Eulálio 168

Pinheiro, Chabi 54

Pinto, Álvaro Vieira 70

Pinto, Cesar 56

Pinto, Edgar Roquete 171

Pinto, Heráclito Fontoura Sobral 175

Pinto, Pedro 73, 74

Pio XI, papa (Achille Ratti) 178, 179

Pio XII, papa (Eugenio Pacelli) 176

Pizzarro, Arthur 21

Pompéia, Paulo A. 107

Porter, Keith 106, 125, 133 
Portinari, Cândido 49

Porto, Marques 142

Porto-Carrero, Julio 46

Prestes, Luiz Carlos 47

Prévert, Jacques 82

Prigogine, Ilya 17

Proust, Marcel 53, 121

Prowazeck, Stanislas von 97

Pullman, Alberte 114

Pullman, Bernard 114

$\mathbf{R}$

Ramon, Gaston 81

Ramos, José Júlio da Silva 25

Ramuntcho 45

Reagan, Ronald 181, 182

Rebelo, Marques (pseud. de Eddy Dias da Cruz) 186

Renaud, Madeleine 55, 82

Rezende, Leonidas 27

Rezende, Marieta 27

Rezende, Silvia 25

Ribeiro, Anna Francisca Falcato 109,128

Ribeiro, Carlos Antonio de Leers

Costa 147

Ribeiro, Carlos Flexa 161

Ribeiro, Darcy 136

Ribeiro, João 25

Ribeiro, Joaquim da Costa 73, 93, 118, 146, 147, 148

Ribeiro, Paulo Assis 145

Righi-Lambertini, dom 174, 175

Rivet, Paul 159

Rocha, Plínio Sussekind da 20, 70
Rodrigues, Figueiredo 175

Rodrigues, Glauco 49

Rodrigues, José Carlos 22

Rôla, Joaquim 96

Rolland, Romain 53

Rondon, Cândido 167

Rothschild, Edmond de 79

Rousseau, Jean-Jacques 11

Roux, Émile 81

Rovasenda, Enrico di, padre 176, 185

$\mathrm{S}$

Sablon, Jean 82

Salam, Abdus 156, 188

Sales, Eugenio, cardeal 174

Salles, João Batista Veiga 86,87

Salles, José Veiga 94

Salviucci, Pietro 178, 185

Santos, Alberto Cruz 26

Santos, Marcelo Damy de Souza 17, 107,149

Santos, Maurity 43

Santos, Reinaldo Cruz 26

Santos, Roberto 143

Sarraihl, Jean 159

Saville, Helen 77

Scarabotolo, Hélio 160,172

Scharfstein, Júlio 128

Schipa, Tito 54

Secondi, frei 70,175

Ségur, condessa de 23, 53

Sena, Sílvia Amélia Mello Franco 191

Senna, Múcio de 191

Serra, Maria Eugenia 25

Silva, Carlos Ribeiro da (capitão) 29 
Silva, Antônio Carlos de Andrada e 65

Silva, Augusto da 112, 197

Silva, Herminia Lyra da 21, 22

Silva, Maurício da 156

Silva, Otávio Couto e 49

Simon, Michel 167

Singerman, Berta 55

Soares, Rachel Ribeiro dos Reis 197

Soares, Raul 50

Sollero, Lauro 109, 129, 140

Souza, Júlio Cesar de Mello e 193

Souza, Wanderley de 114

Student (pseud.) 85

Szent-Gyorgyi, Albert von 79

$\mathrm{T}$

Taccolo 45

Talice, R. 193

Teixeira, Ana Maria Leão (dita Donana) 123, 197

Teixeira, Antônio Augusto 36

Teixeira, Antônio de Castro 37

Teixeira, Carlos de Castro 37

Teixeira, José de Castro 37

Teixeira, Juanita de Castro 36, 37

Thatcher, Margaret 181

Tiselius, Arne 133

Tolstói, Leon 121

Tomita, Tsuneo 102

Torres, Carlos Bastos Magarinos $36,46,63$

Travassos, Lauro Pereira 57

Tréfouel, Jacques 187, 196, 198

Tréfouel, Thérèze 196

Trenet, Charles 82

\section{U}

U Thant 150,151, 152, 154

Ullmer, Georges 82

V

Vaccani, Silvia 26

Vale, Ciro de Freitas 70

Valéry, Paul 49, 50, 79

Vallery-Radot, Pasteur 187, 195, 196

Vargas, Getúlio Dornelles $65,67,70,75,118,146,174$

Vaz, Juvenil da Rocha 68

Venâncio Filho, Francisco 171

Venàncio, Joaquirn 61

Verdi, Giuseppe 53

Verne, Jules 53

Vianna, Baeta 75,86

Vianna Filho, Luiz 158

Vianna, Lozir 33

Vianna, Luiz 173

Vieira, Domingos 9

Villaça, Hermenegildo 37

Villaça, João 37

Villegas, Raimundo 188

Villela, Eudoro 33, 35, 88, 124

Villela, Eurico de Azevedo 33, 36

Villot, cardeal 175

Viola, Giacinto 68

Voloch, Aida Hasson 109, 126, 127

W

Wagner, Richard 54

Waldheim, Kurt 181 
Índice onomástico

Waldner, Silvia Amélia Chagas de 151, 193

Wataghin, Gleb 107

Watson, James Dewey 135

Weisskopf, Victor 181
Wilkins, Maurice 83, 135

Wurmser, René 18, 70, 78-80, 97 , 104-106, 121, 123, 145, 198

Wurmser, Sabine Filitti

$78,97,104,121,123$ 

Retratos 
Fazenda Sobragi, próxima a Juiz de Fora, propriedade do tio materno, o empreendedor e positivista Otávio Cameiro. "Sonho de calnuaria e beleza campestre", Sobragi foi sua "primeira estada no campo". Amigos $\mathrm{e}$ parentes do Autor, s./d.

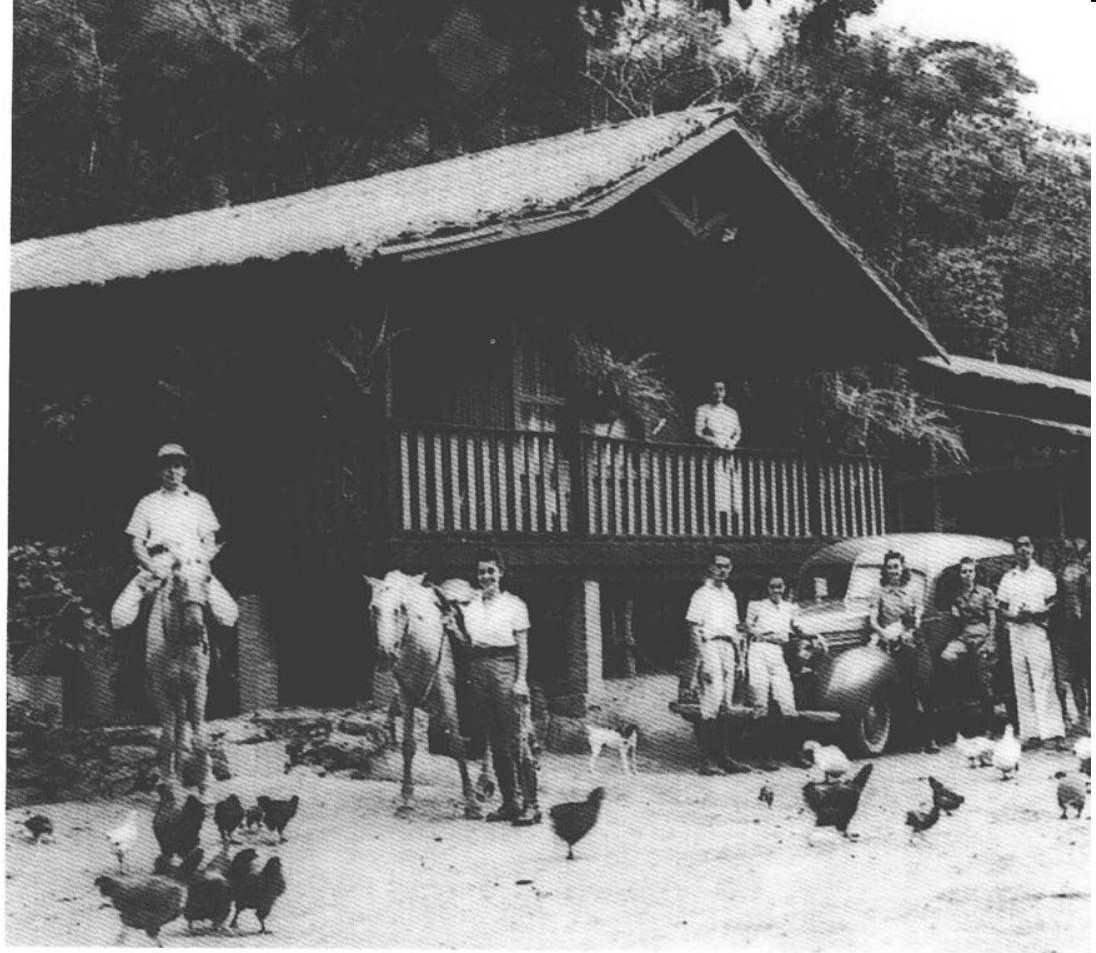

Fazenda Tartária, propriedade do tio paterno

Henrique

Ribeiro de Castro, próxima a Oliveira, "onde aprendi a conviver com as gentes $\mathrm{e}$ a conhecer a hospitalidade do povo brasileiro"

(Marins, H.T., Sedes de fazendas mineiras, BDMG Cultural, 1998, p.117)

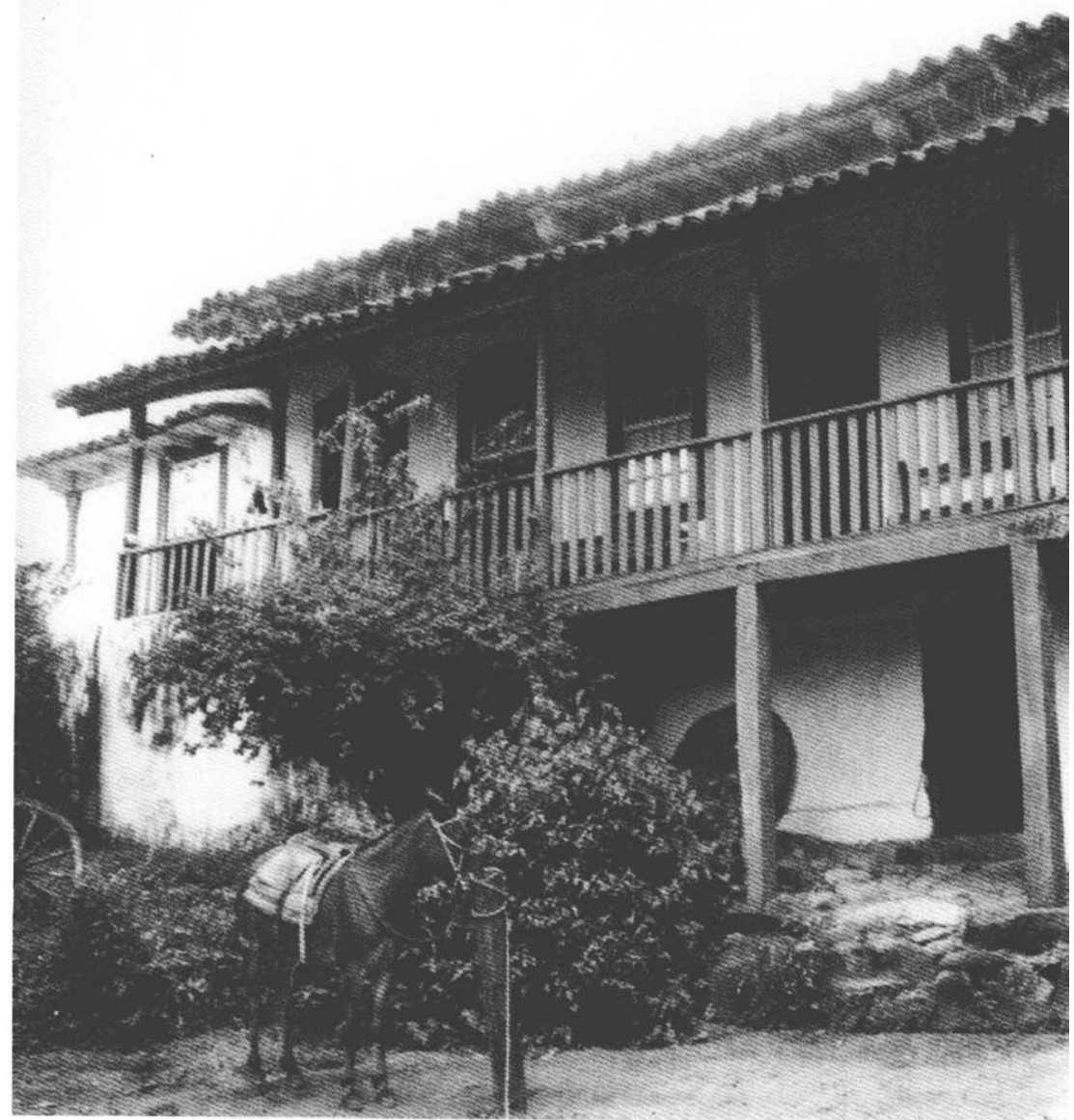




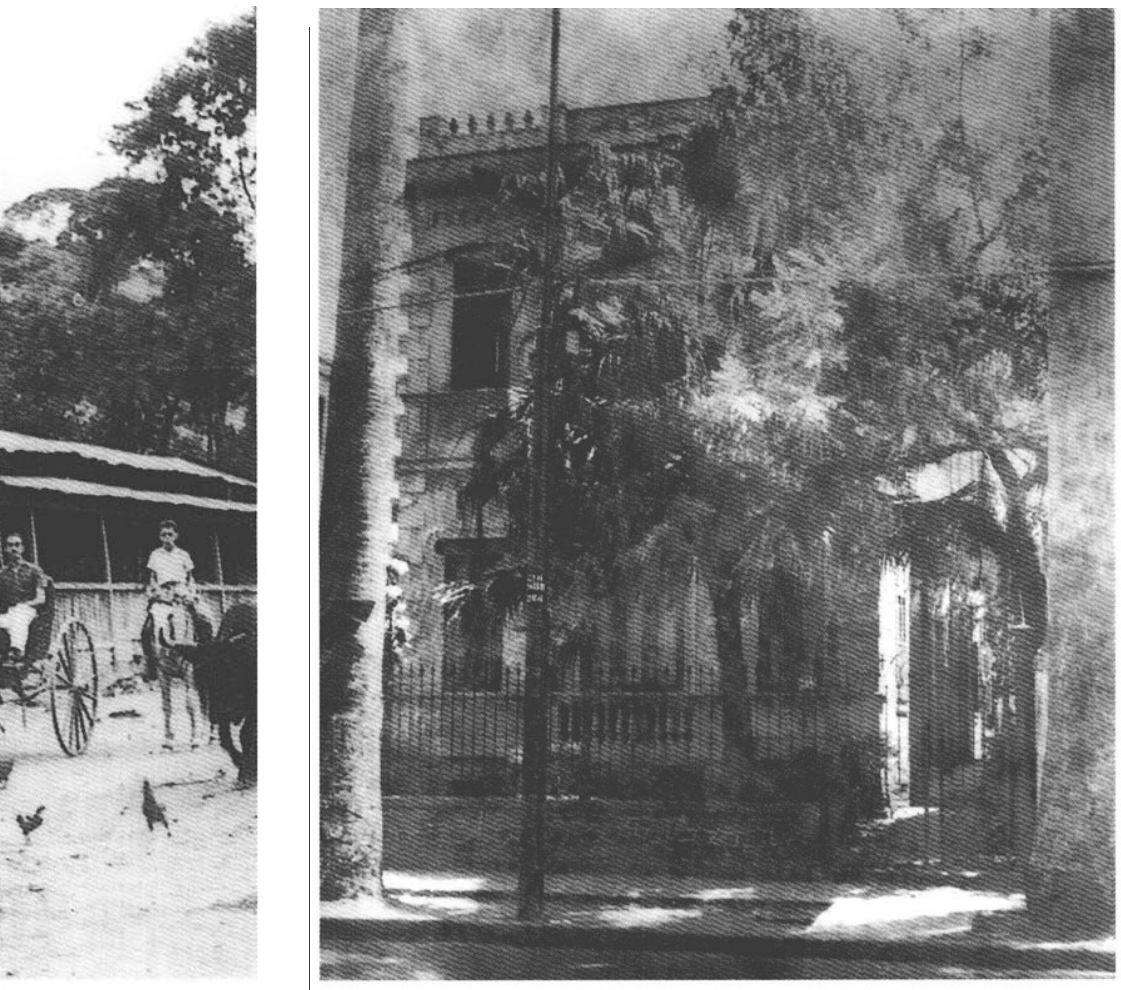

Casal da rua

Paissindu, 148 . onde conviveu com os pais. visitas ilustres, Fränlein 1)inges e I iomedes, manteve no pontar "um diálogo solitário" com a natureza, e incorporou, en sua tantasia, as façanlas do "Coraçà̃o Leal". s. $/ \mathrm{d}$.

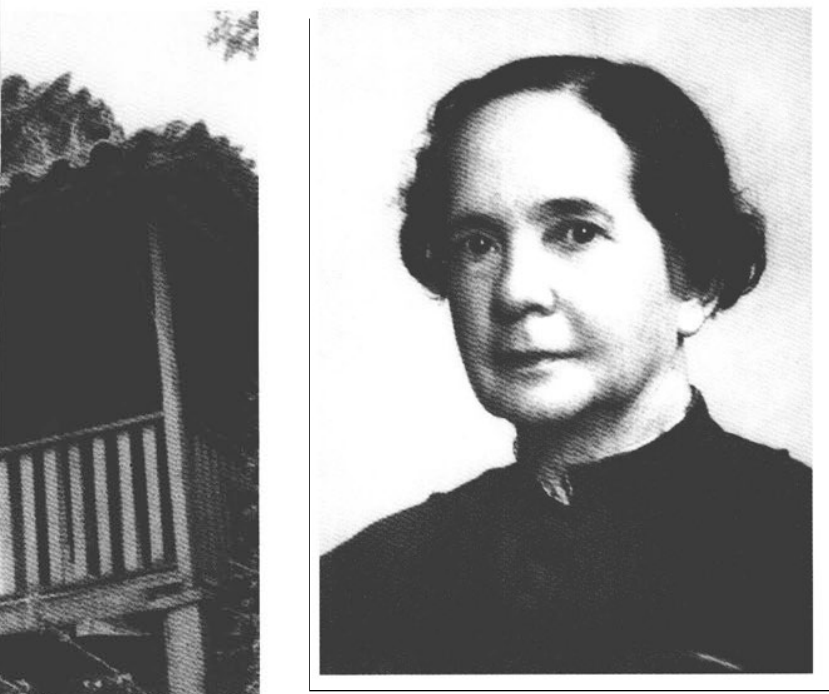

Marictis Rezende, "mentalidade progressista e inovadora", diretora do Colégio Rezende, "onde aprendi, realmente, a disciplina do estudar, o que fez. desabrochat e fortalecer meu espirito", s./d.

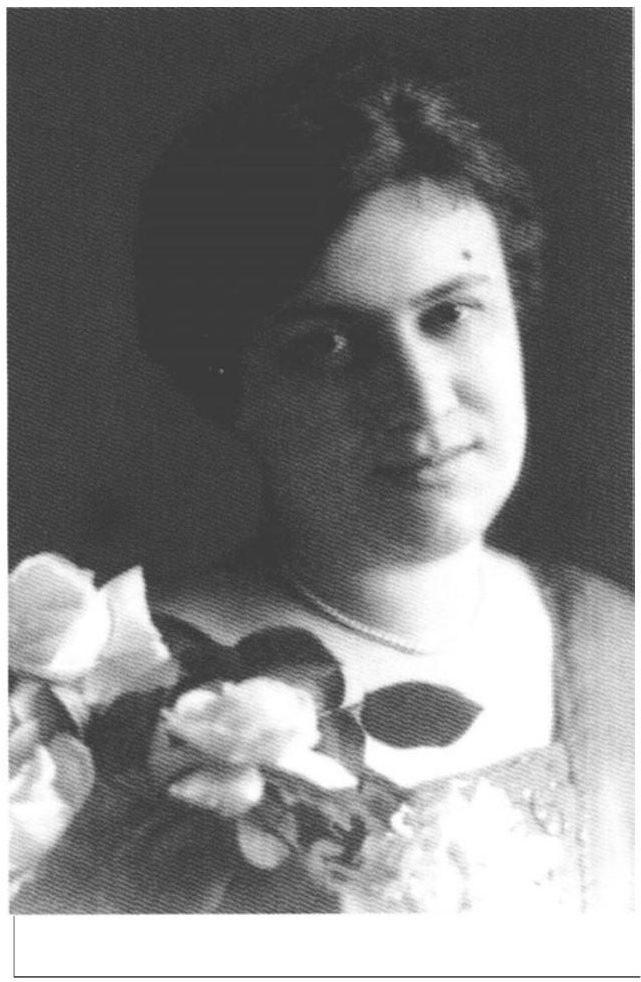

Iris Lobo Chagas, mãe de Carlos Clagas $\Gamma$ ilho, s./d. 


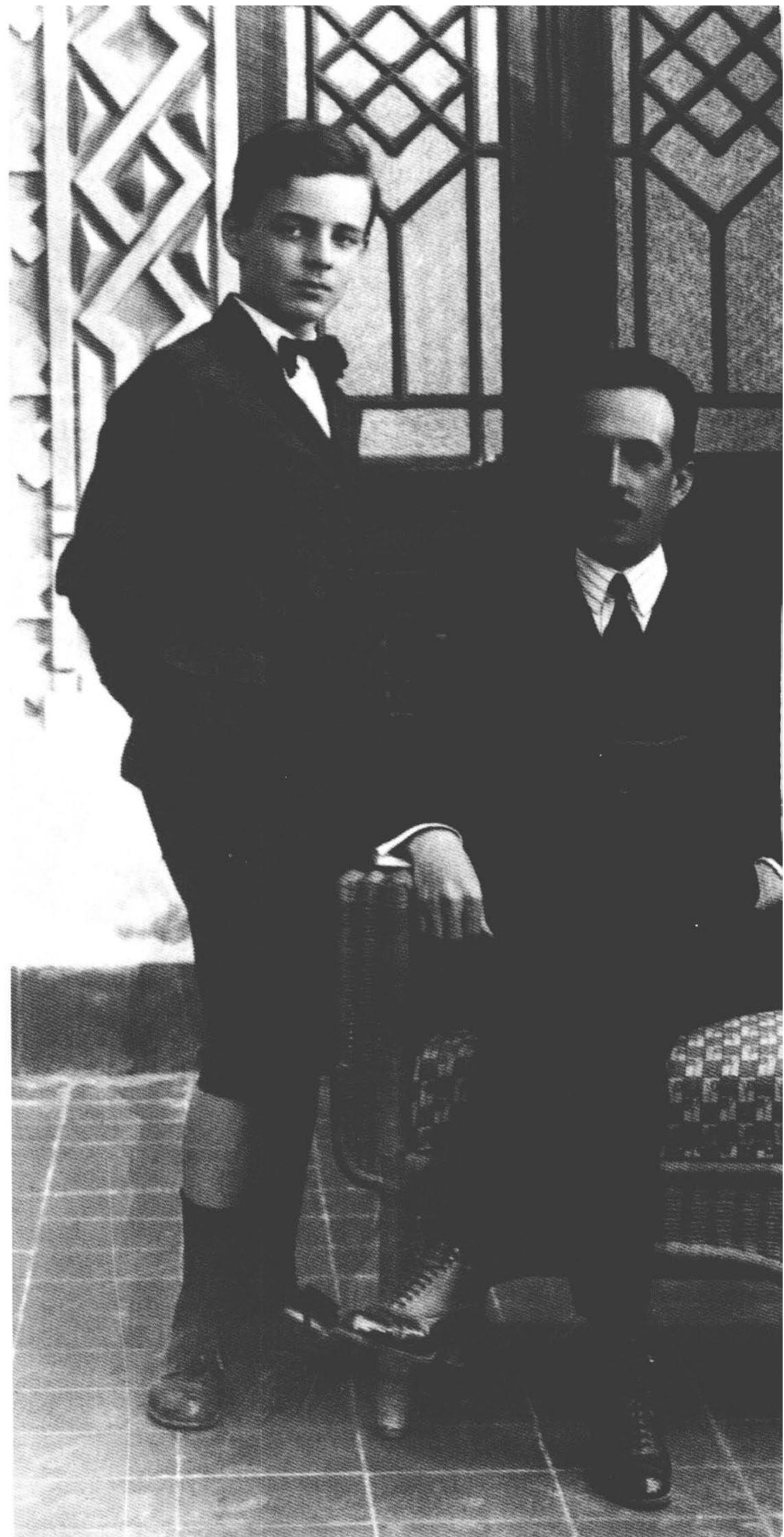




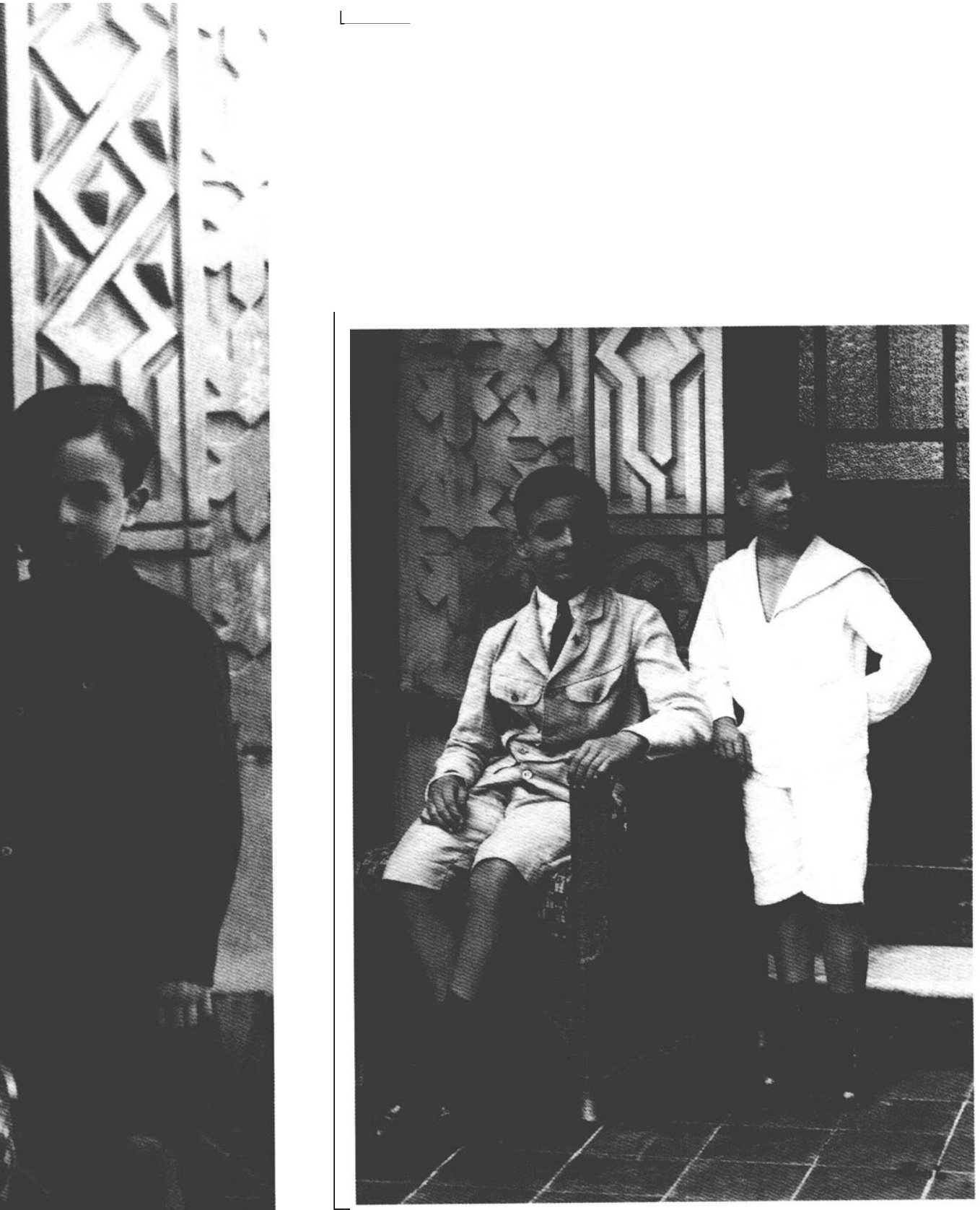

Evandro e Carlos Chagas Filho, 1915 
Recémemposianto na cátedra de fisica biolongica, embarca pira a Europia com dona Annals. asompinblados de

1)ora C.ampos (centro). filba do ministro franciso

C.ampos. Na despedida, Evandro Chagis, sua esposa Agrses Wadded (dragas,

Alnuir Castro, Virgulio Carmeiro c sembora Kenmets Waddel, 19.37

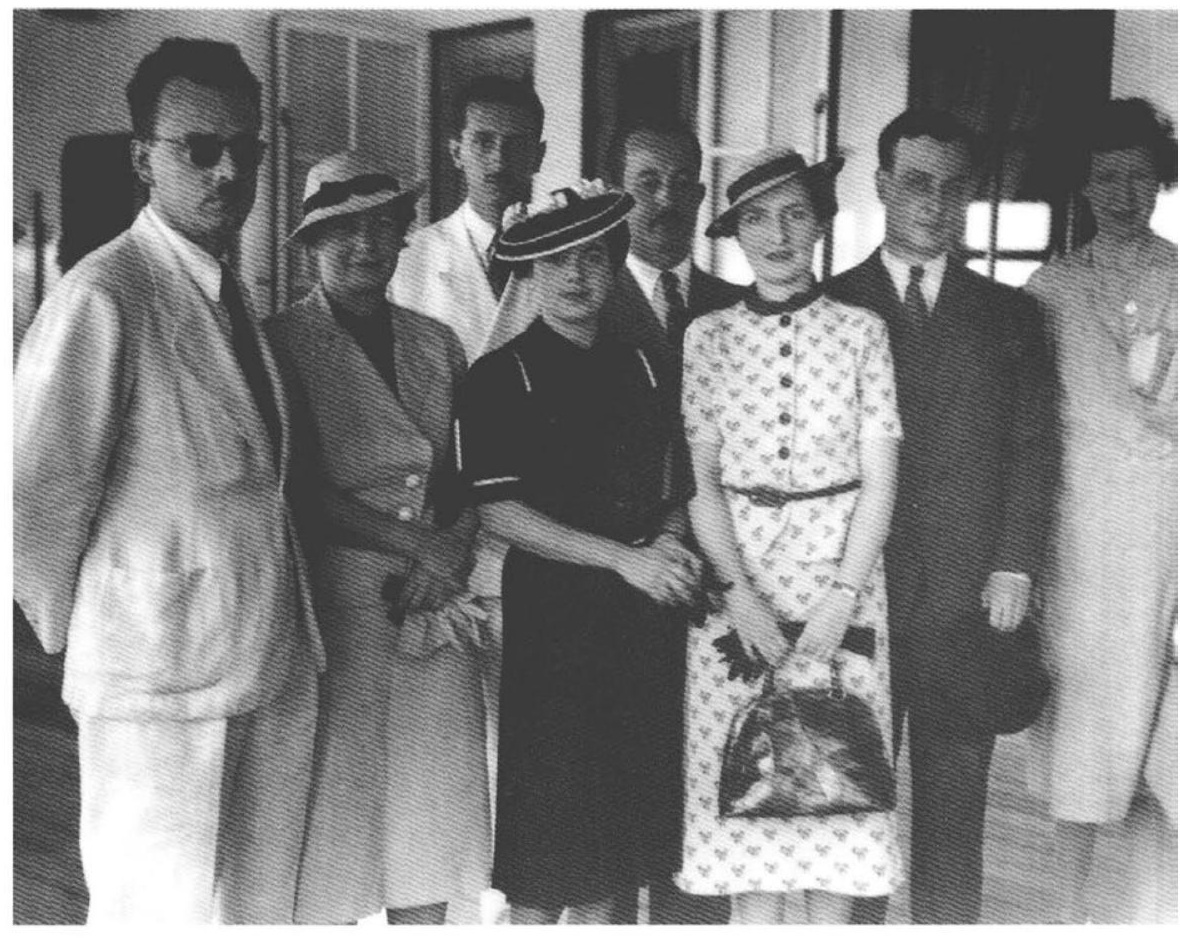

1) aude bona-vindats a bordo de navio. 1)a escy. para a der.: Maria do Carmo Nabuco, Joio Vitur de Mello Franco,

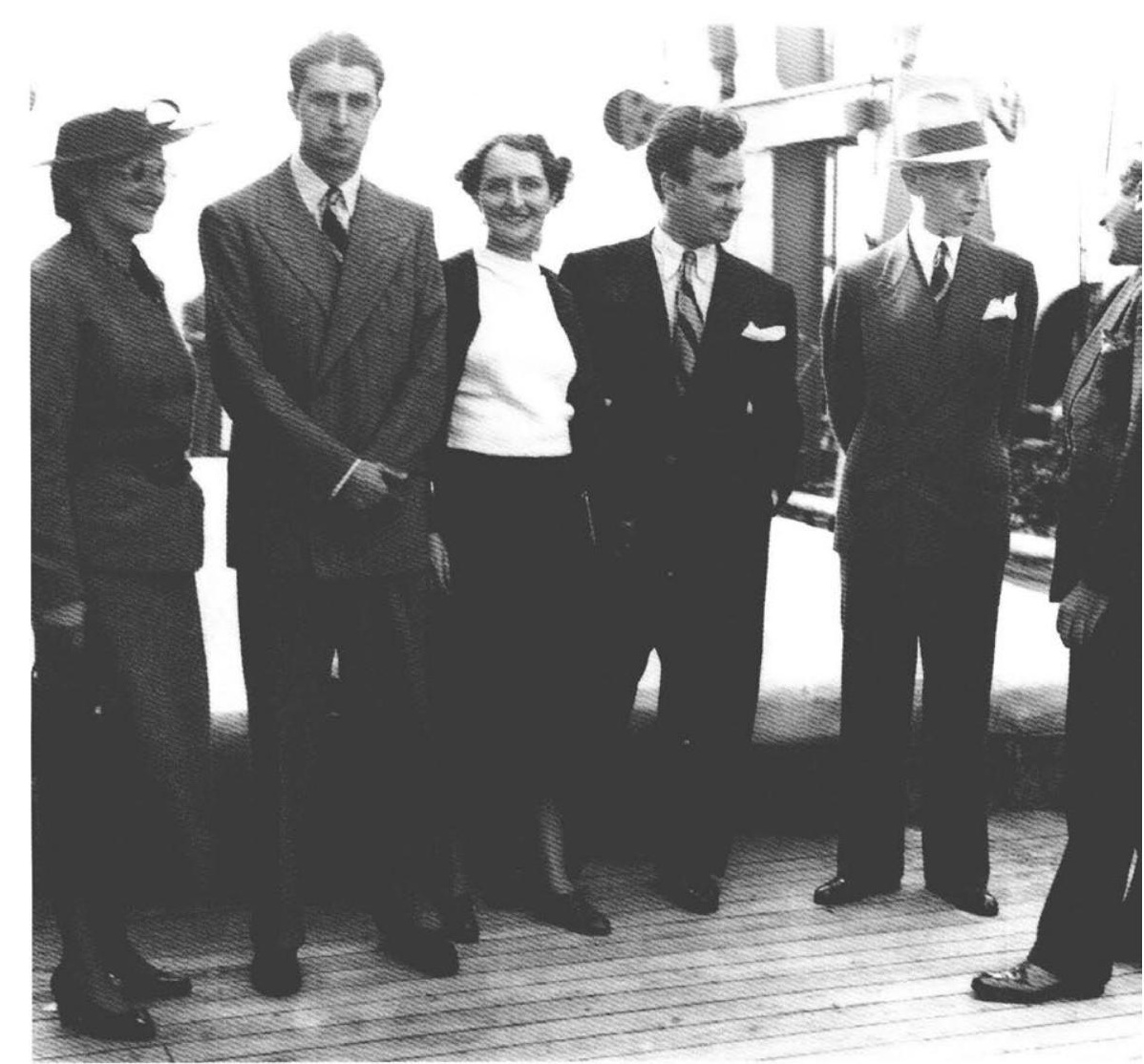
Antra Leopolditra, Carlos Chamas Fillu, Afrinto de Mello I*ranto e cmbarisador I'io Manuel Correna, s.d d. 

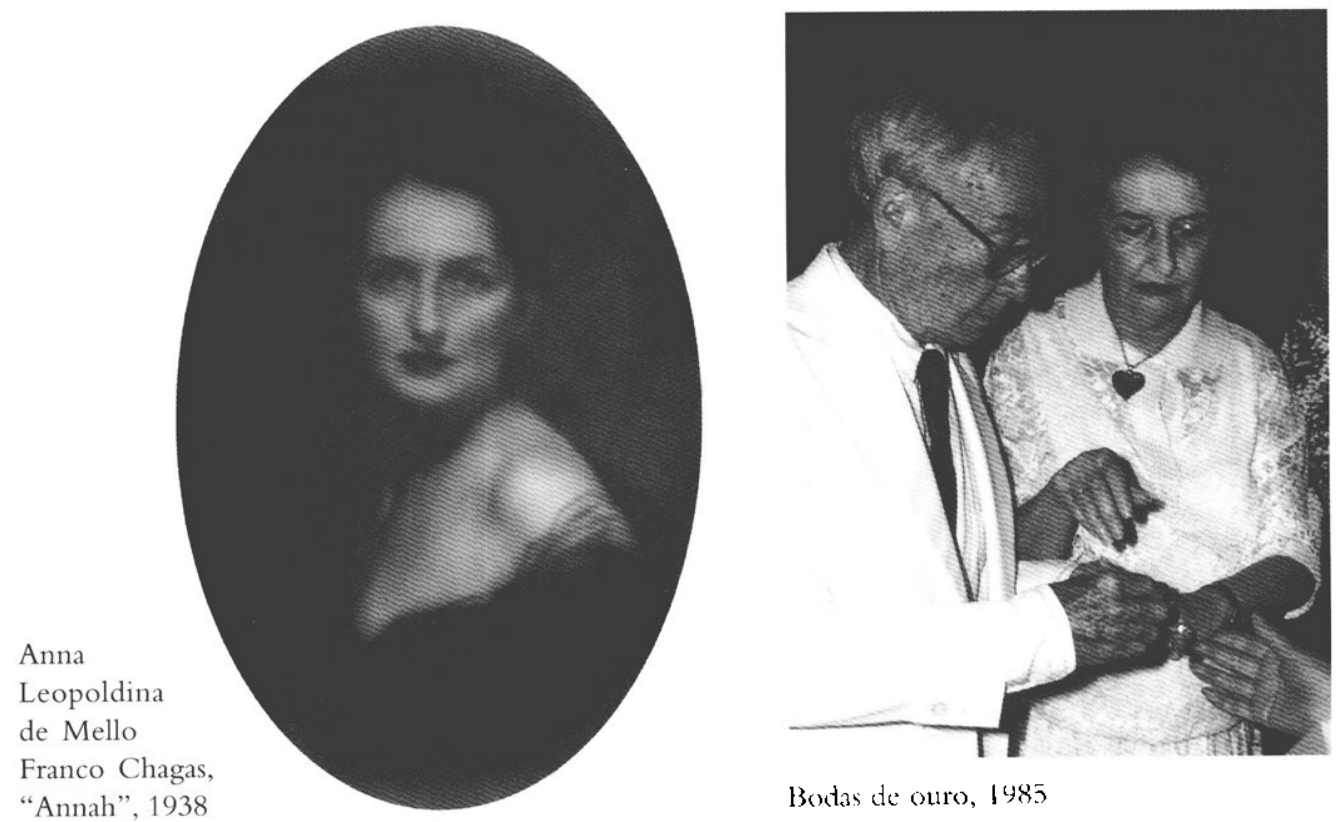

“Annah”, 1938

Bodas de ouro, 1985

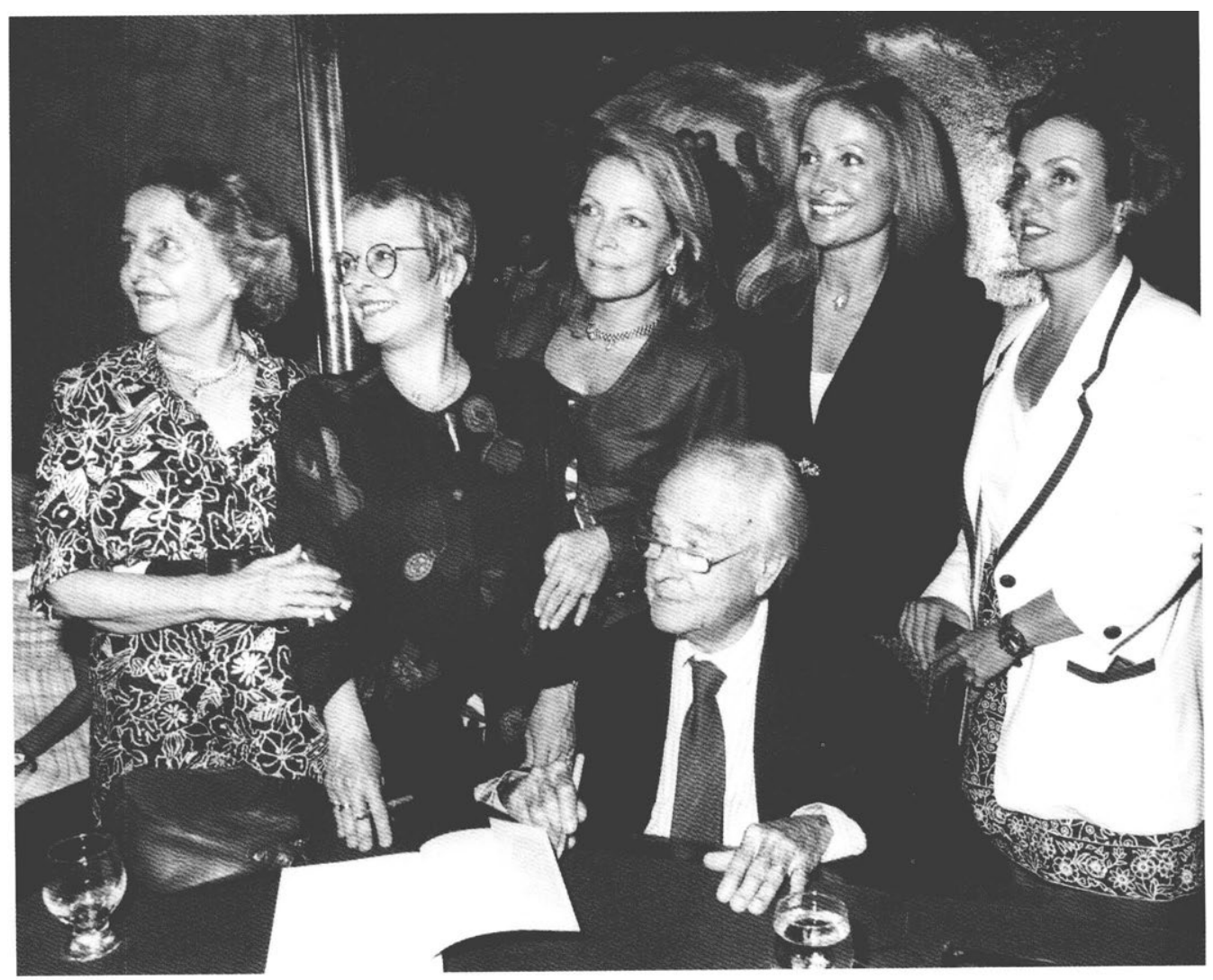

Em estado de graça, com dona Annah e as "quatro filhas únicas" (a partir da esq.):

Anna Margarida, Maria da Glória, Silvia Amélia e Cristina Izabel. Lançamento do livro Meu pai, 1993 
ABC salteado dos Chagas

Neste meu ABC canta

Anna Leopoldina - Annah

Chagas (pelo pensamento)

Perfeição como não há.

Sendo Annah assim perfeita, que belas filhas que tem!

Mas a paz que as une e anima é das almas que ela vem.

(...)

Odylo Costa, filho 


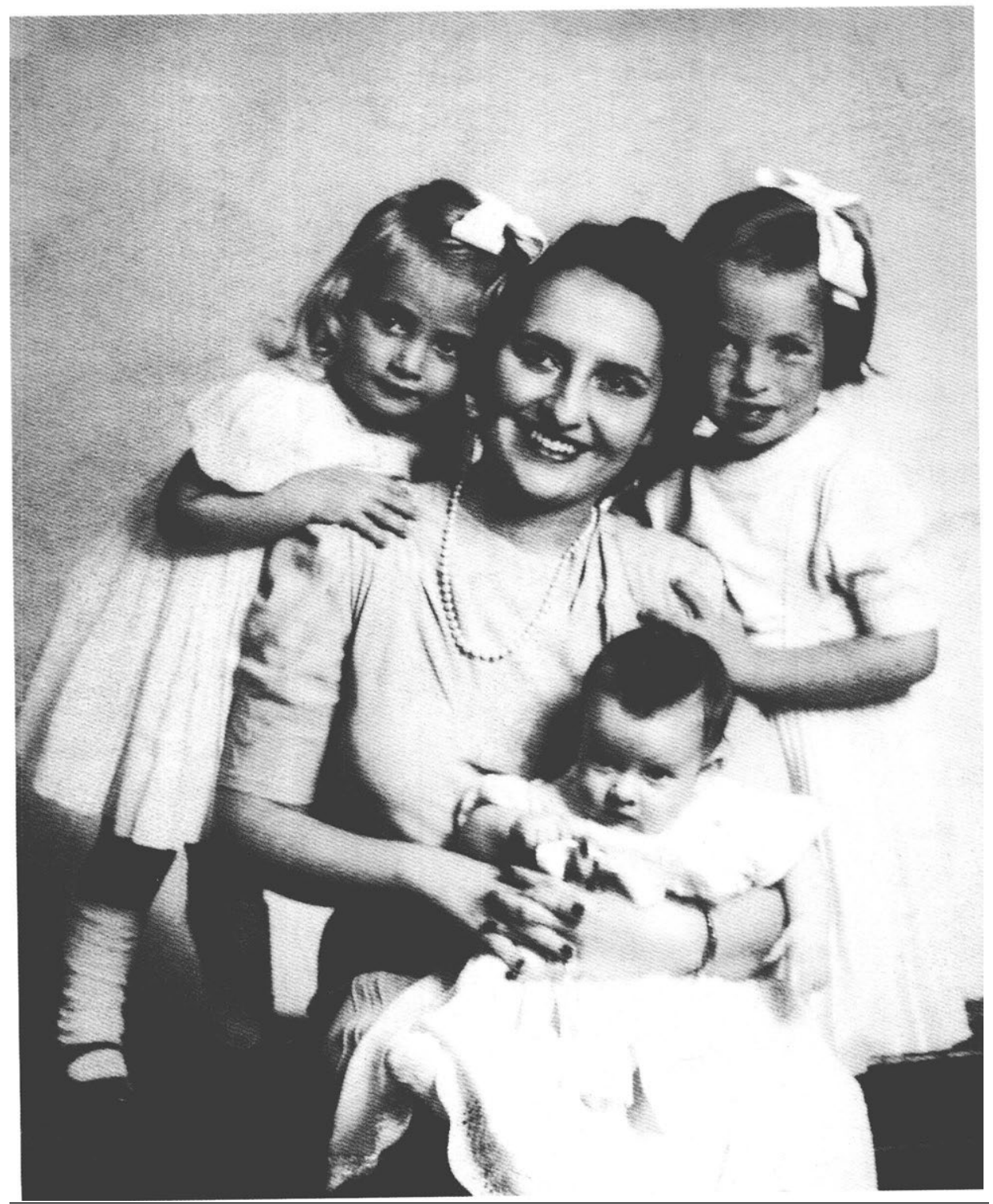

Dona Annah com as filhas. No colo, Anna Margarida; à esq., Silvia Amélia e, à dir., Maria da Glória. Cristina Izabel não era nascida, 1944 


\section{A familia Carlos Chagas Filho, em poemas de Mantel Bandeira}

Carlos Chagas Filho

Não degenera quem sai

Aos seus - $e^{2}$ a lição da história.

Este, que com grande brilho

Já foi Carlos Chagas Filho,

Junta a do seu pai a nova glória,

E hoje é Carlos Chagas pai

Maria da Glória Chagas

Esta é a Clória, esta é Maria;

Nome que é nome e renome.

Claro está que com tal nomo

Será - fácil profecia -

Boa filha, boa imã c

Boal esposil. () anjos, dai-

Lhe a gentilezal da màe,

A inteligencia do pai.

Nesta vida transitória

Chagas tenha só no nome,

- Nome que é nome e remone -

- E tudo o mais seja glória.
Ana Margarida Maria

Ana - Sant'Ana - principia,

Maria acaba. Entre elas brilha

Uma flor branca. E eis, maravilha

De pureza, graça, alegria,

Ana Margarida Maria

Sílvia Amélial

Tudo quanto é puro e cheira:

- Manacá, jasmim, camélia,

- Lírio, flor de laranjeira,

- Rosa branca, Súlvia Amélia!

Cristina Izabel

Viva a xará da Imperatriz,

Da Princesa e da Mãe de Deus!

Viva a que é a mais moça dos seus

E a mais nova das minhas Musas,

Toda graça, encanto e harmonia,

Geração de um casal feliz,

Sobre a qual, sobre a qual, profusas,

Chovan as bençãos de Maria! 
ANA MARGARIDA MARIA

Ana - Sant'Ama - punsaitina.

Navia acaba. Sutre elas bisitha tuma flor branca. Ieri, mascarit tha

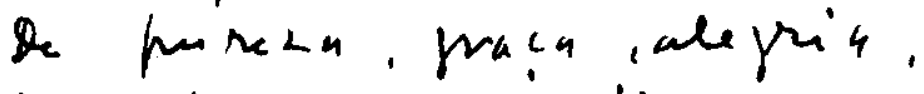
tran Marqainda Maria.

Mannel trov tin 


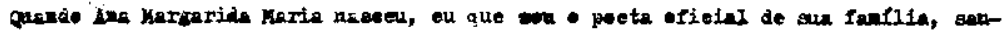

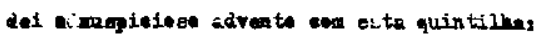
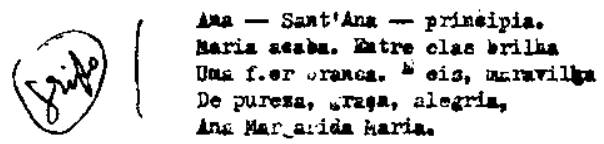

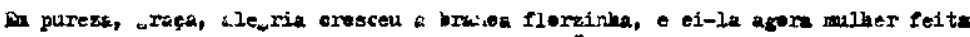

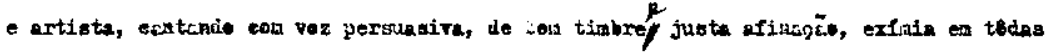

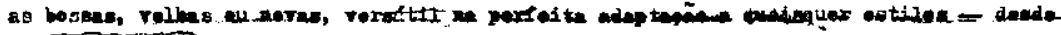

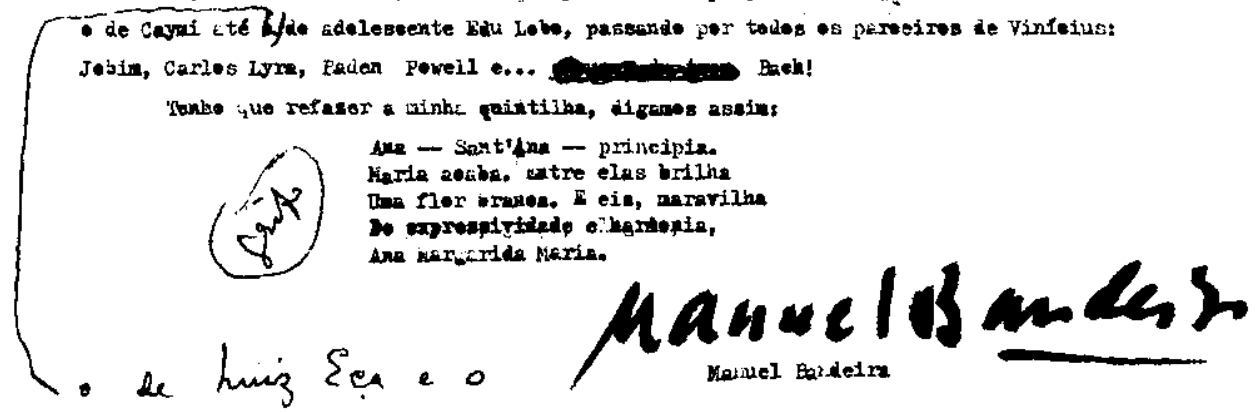




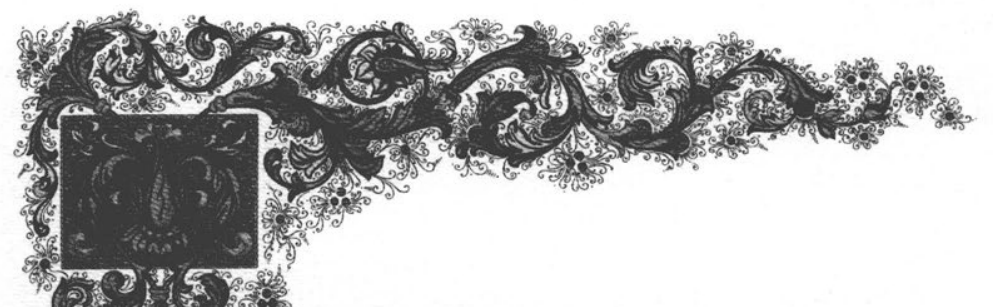

AOS 40 ANOS DE CARLOS E ANNAH

Não quarenta anos de Carlos nem quarenta anos de Annah: quarenta anos de uma casa que é a casa mais bela que há.

Para festejar a data numa alegria conjunta ninguém falta. Creio mesmo que o marca-passo se junta.

Nós todos, irmãos, amigos que também somos irmãos, em redor desses dois pássaros. unidos, damos as mãos.

Pássaros? Sim. Bem sabeis que a alma dos dois é mais leve que o vôo branco de uma ave cortando a neve da neve.

Leve até mais do que o trigo antes de transfeito em pão. Duas almas juntas numa, a luva ajustada à mão.

Campo lavrado, altar santo, nasceram do seu amor frutos que já deram frutos: continuam sempre em flor.

Em em flor vão envelhecendo. Que Deus os conserve assim, cheirando a flores do campo, a rosa, cravo e jasmim.

Odylo Costa, filho

Lembrança de dez anos mais tarde 6 de Julho 1985 


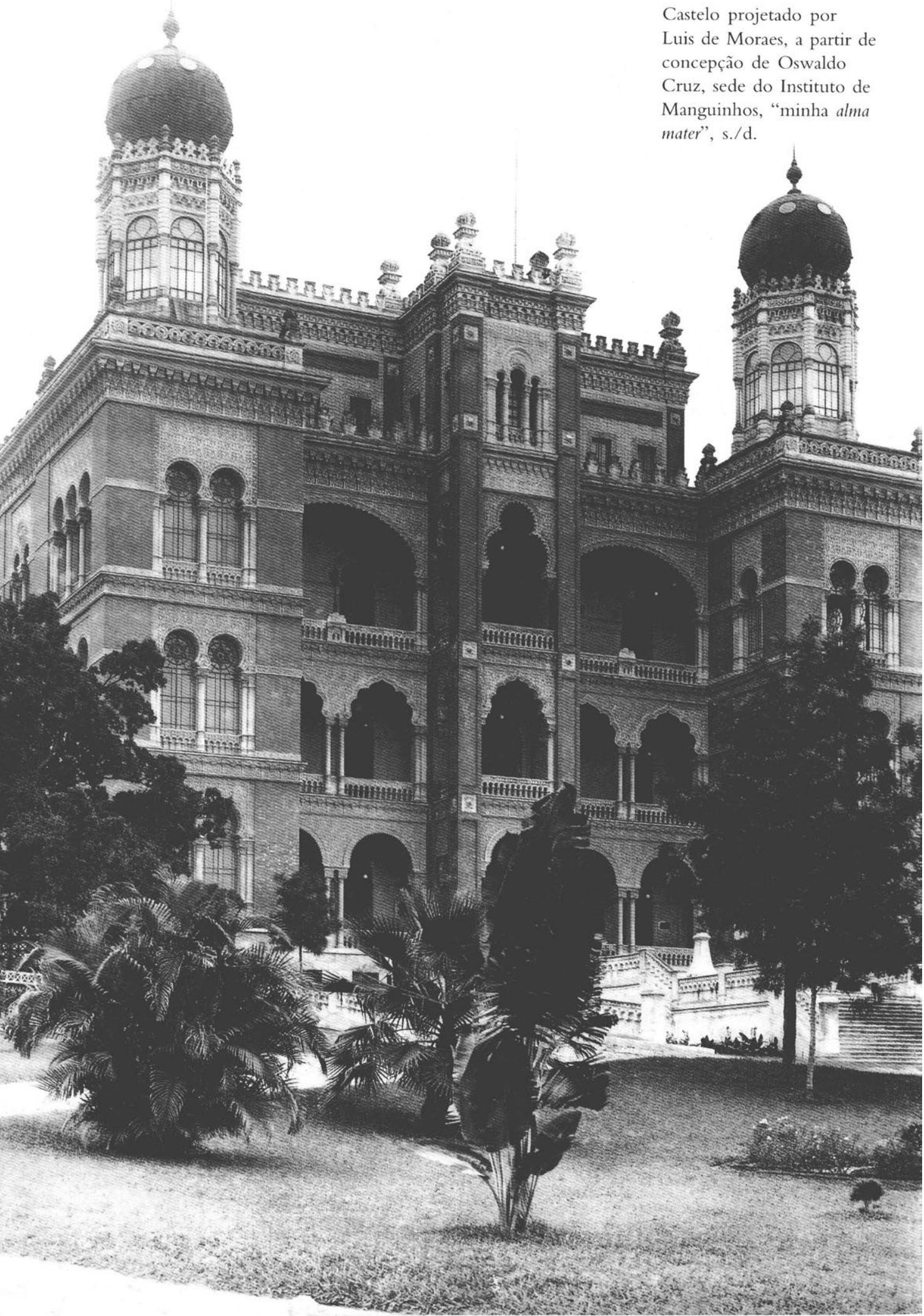




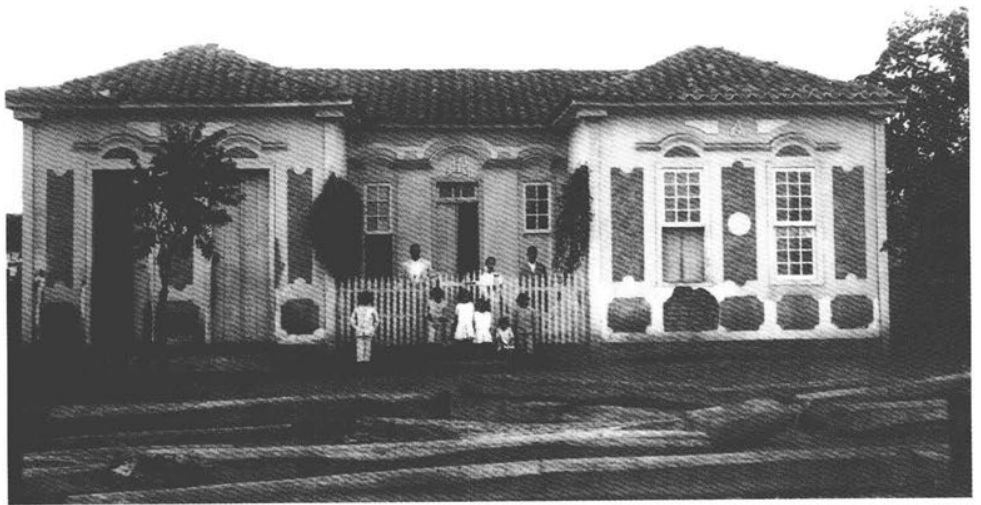

Hospital de Lassance, onde completou sua formação médica. "Foi, sem dúvida, en Lassance que aprendi a conhecer as gentes $\mathrm{e}$ a apreender melhor o que é a vida. O contato com os pacientes, a simplicidade de linguagem e a sinceridade dos sentimentos do povo que ali conheci foram da maior valia para a formaçâo de minha personalidade", circa 1913

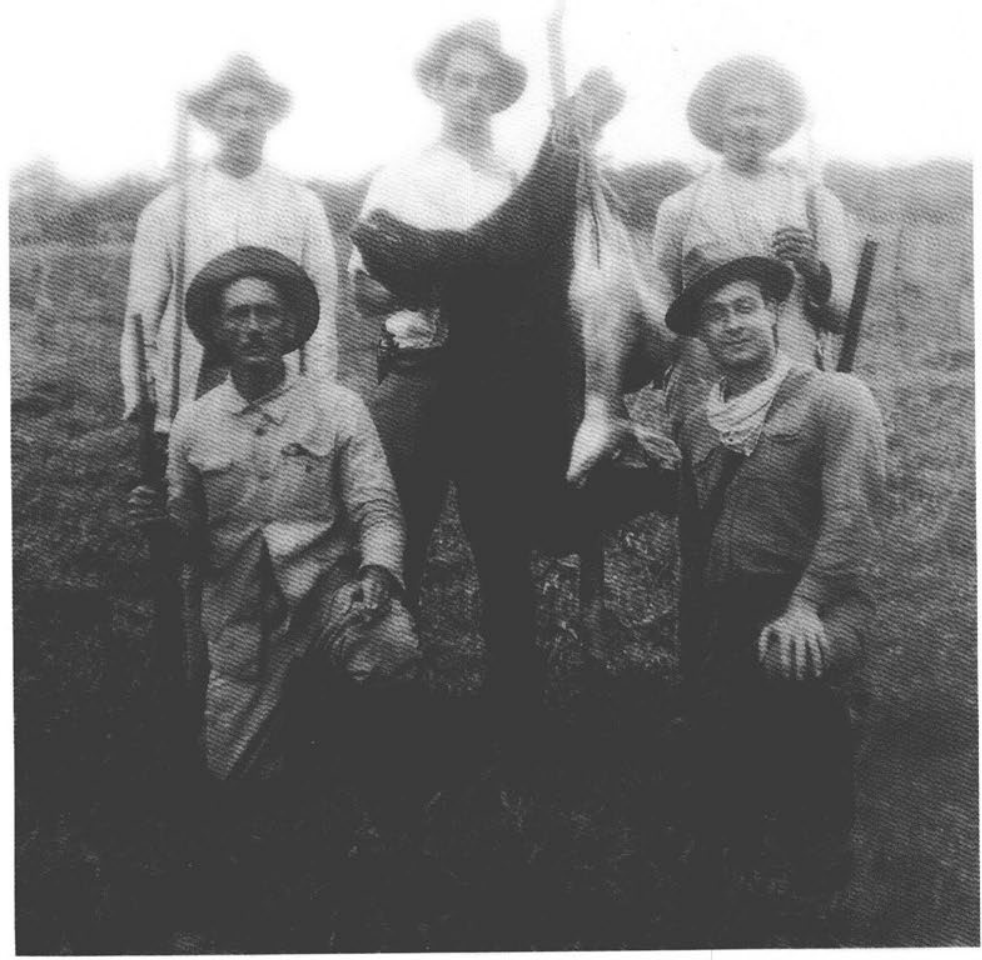

Uma das fotos preferidas de Carlos Chagas Filho. Herdando o gosto pelas caçadas e a "pontaria do pai", posa orgulhoso com a onça preta que abateu na serra do Cabral, Lassance, 1930 
Cientistas do

lnstituto Oswaldo

Cruz no

caramanchão da

Casa de Chá, com

Max Hartmann e

Prowazek.

De pé, da esq. para

a dir.: Arthur

Neiva, Henrique da

Rocha Lima,

Henrique

Figticiredo de

Vasconcios,

Honrique Aragào e

Alcides Grodoy.

Sentados, da escy.

para a dir.: Carlos

Chatras. José

(iomes de Faria,

Max Hartmann,

Oswaldo Conçalves

Cruz, Stanilas von

Prowazek e

Adolpho L.utz, 1908

Oswaldo Coruz no tcrraço do Castelo

Mourisco, com

integratutes da Escola

de Manguinhos.

Sentados, da esc. para

a dir.: Osvino Pena.

Adolpho Lutz,

Oswaldo Cruz,

Carlos Chagas e

Walter (Oswaldo

(iruz. l)e pé, 1" fila:

Edgar da Costa

Percira, Sandoval,

Laturo Travassos.

Fizecutel Dias, Álvaro

Lobo e nào identificado. Úitima fila: Ratul di Primio

(2") e Souza Martins

$\left(3^{\prime \prime}\right)$, entre ontros não

identificados,

década de 1910
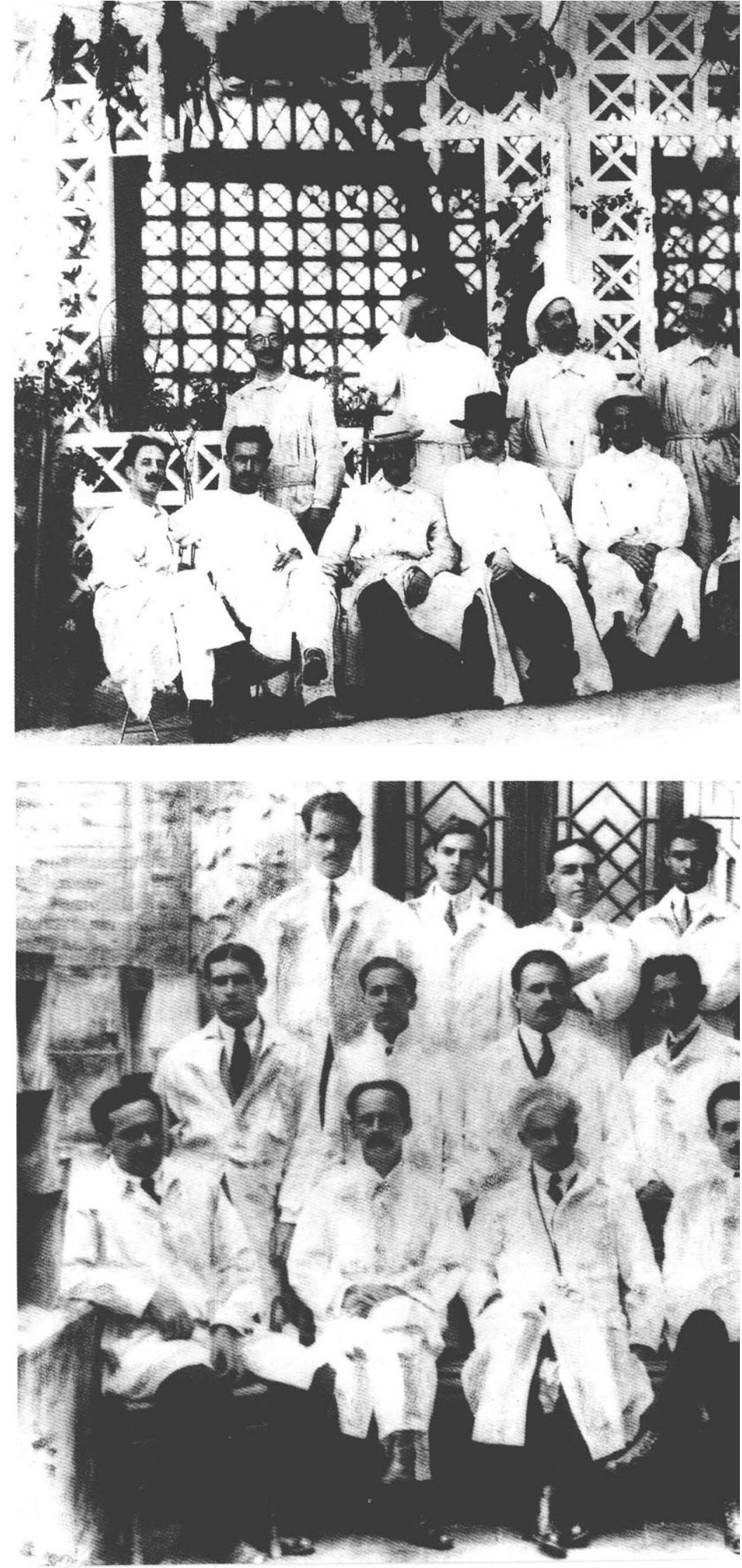

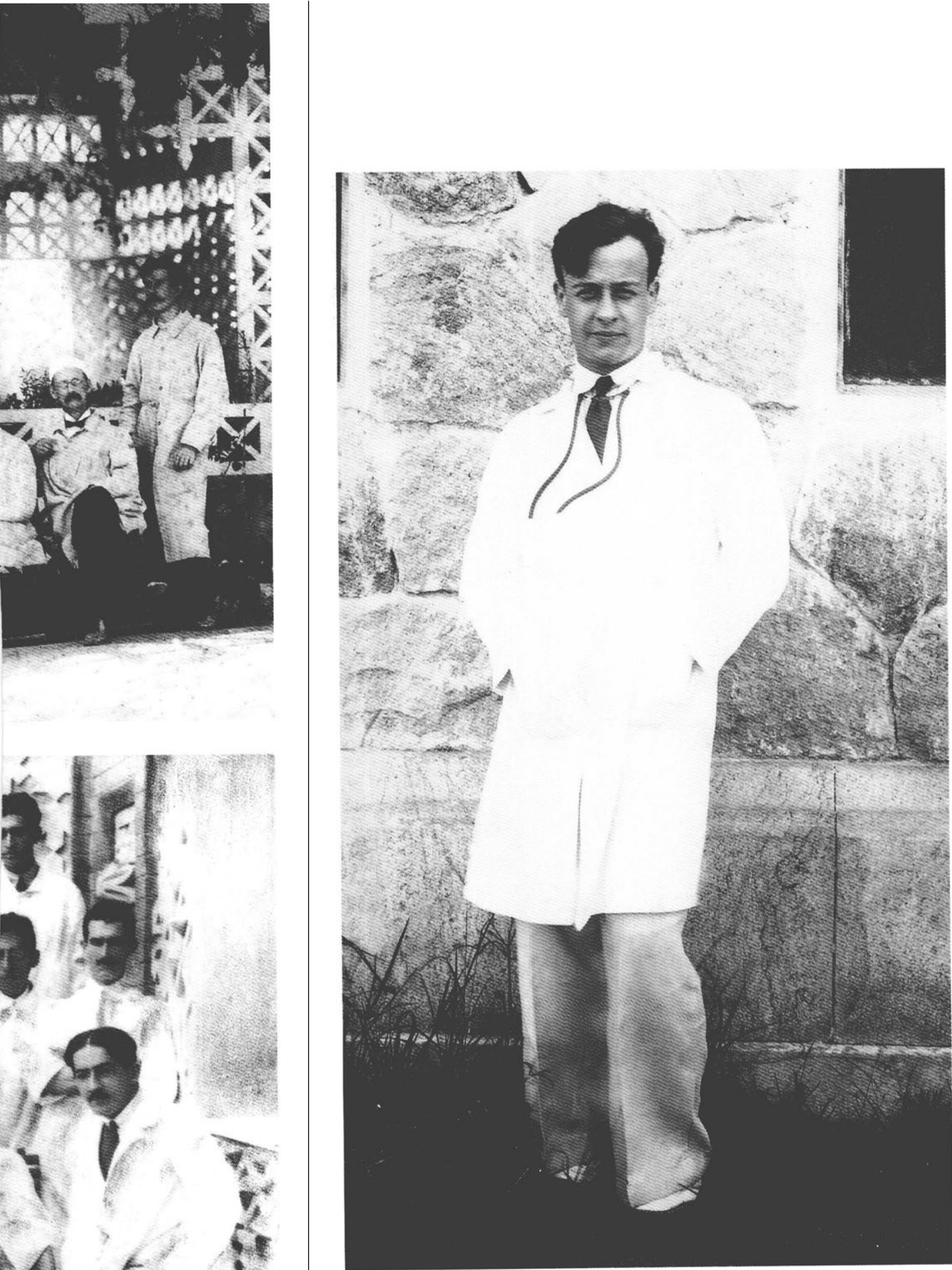

Estudante de medicina, defronte do Hospital Oswaldo Cruz, mais tarde Hospital Evandro Chagas, onde fez sua injciaçăo científica com José Guilhermc Lacorte e "despertou para a importància das condiçöes sociais na evolução de una doença", 1926 


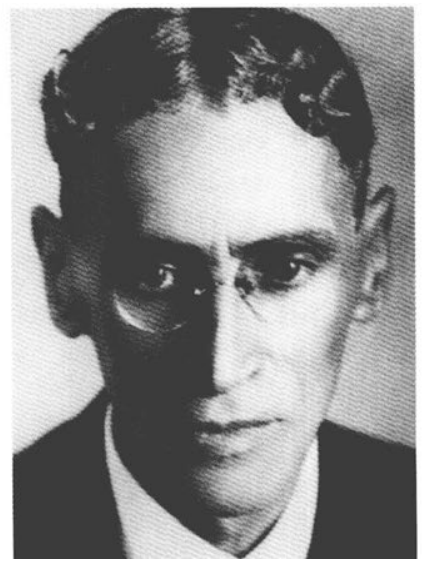

José Carnciro Felippe, convidado por Carlos Chagas para desenvolver a fisicoyuínica no Instituto de Manguinhos, foi quen "ao lado de meu pai, me indicou as veredas da pesquisa cientifica c mostrou-me a importincia do encontro da ciencia com as outras atividade's do espírito humano". s./d.

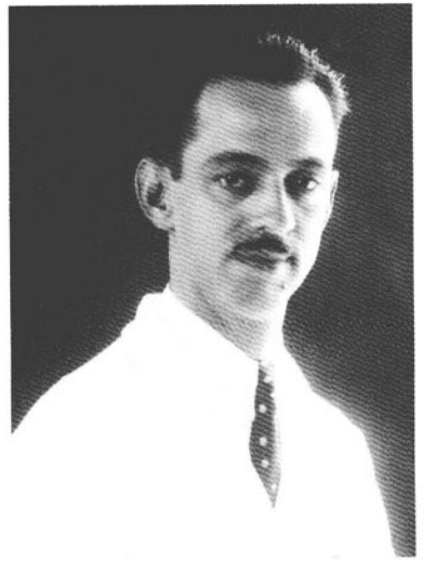

Emmanucl Dias, filho de Ezequicl Dias, colega de faculdade, companheiro on Lassance e especialista en doença de Chagass, "que me acompanhou pela vida inteira", s./d.

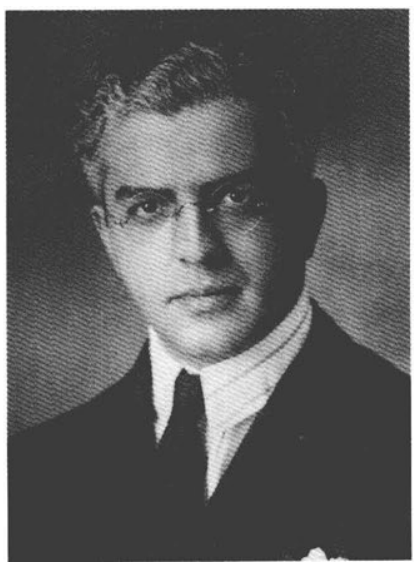

Magarinos Torres. "operário da ciência". Junto com Osvino Pend, Burle de Figueiredo e Azevedo Penna, um dos "titás da patologia de Mangumhos", com os quais estagiou no Hospital Sío Prancisco de Assis, s./d.

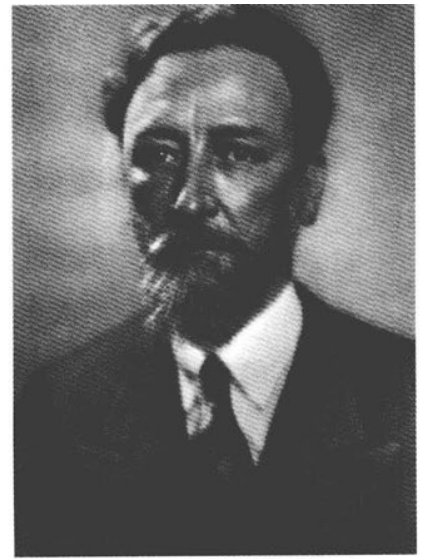

Miguel Ozório de Alneida, pionerio da fisiologia experimental no Brasil, em quem admirava "a perfeiçào. elegancia e economia de gestos c nas experiencias cotidianas", s./. (cortesia do doutor Renato Balào (Cordeiro)

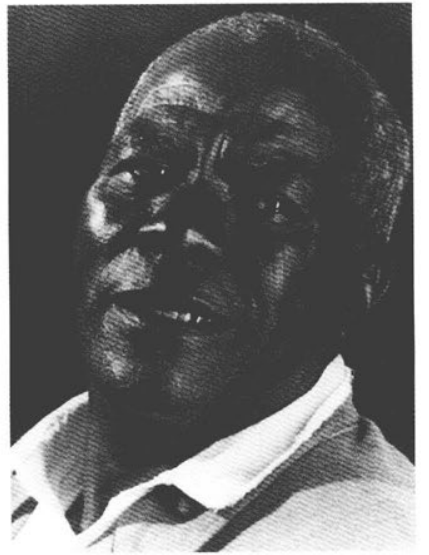

Joapuim Venancio, Natural da fazenda dos avós do autor. revelou-sc eximio artesio científico coll Mangunhos e dá hoje o nome da Escola Politécnica da Fiocruz. "Un dos varós mais completos que conheci, tornou-se mina espécie de babá que me protegeu durante anos", s./d.

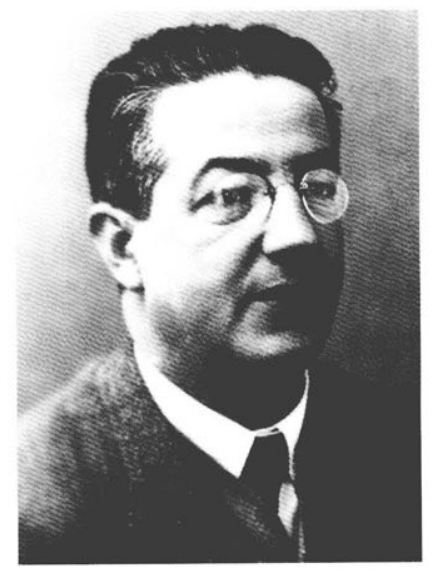

José da Costa Cruz.

"considerado pelo Prêmio

Nobel Jules Bordet um de seus melhores alunos de todas as nacionalidades", foi responsável pela iniciaçăo do autor em microbiologia, s./d. 
Nas escadarias do Castelo de Manguinhos, convidado de hotura da posic dos vice-presidentes da Fiocruz, na gestão de

Sérgice Arouca (à esce).

1). esq. par:1 a dir., Hésio Cordeiro, presidente do Inamps, Arlindo Fábio Ciomez de Sousa e Luis formando Rocha Ferreira da Silva, vice-presidentes empossados. Cartos Médicis Morel, também cmpossado, não aparece bid forto, 1985
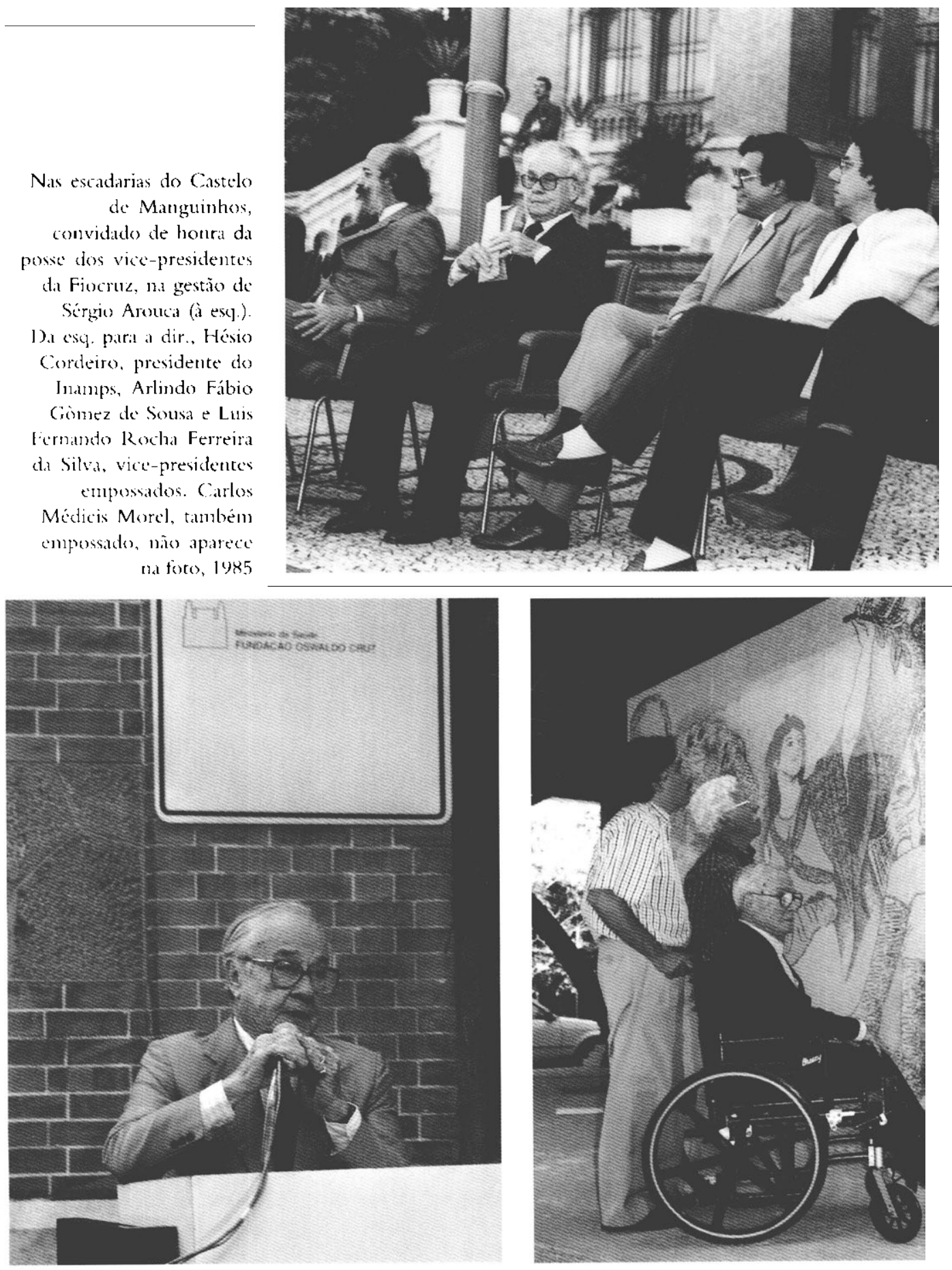

Posse na Presidencia do Conselho Consultivo da Casa de Oswaldo Cruz, no pátio da praça Pasteur. Manguinhos. 12 de naio de 1987

Apreciando com Paulo Gadelha, coordenador do Museu da Vida, paine! de Glauco Rodrigues (de óculos), que retrata a epopéia de Manguivihos nos feitos de Oswaldo Cruz e Carles Chagas. Centro de Recepção do Museu da Vida/ COC/Fiocruz, 1999 


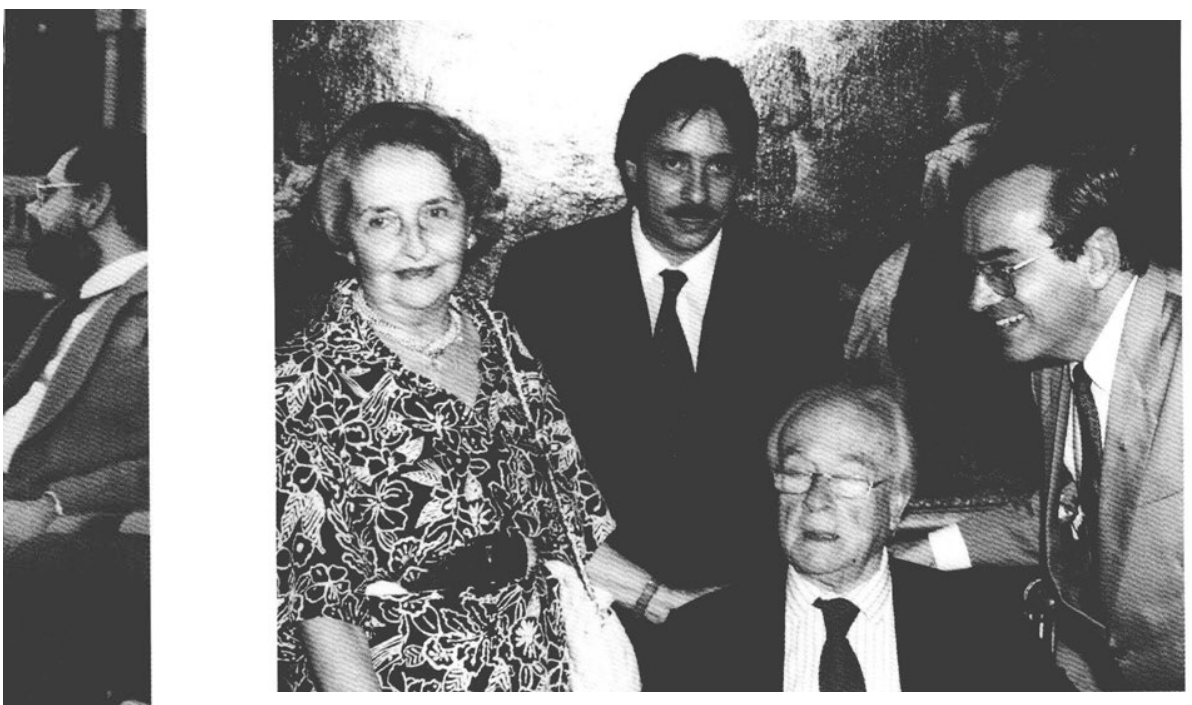

Carlos Chagas

Filho e dona

Annah, com

Paulo Gadelha, diretor da Casa de Oswaldo Cruz (ao fundo), c Carlos Médicis Morel, presidente da Fiocruz.

Lançamento do liveo Mcu pai, $\mathrm{ABL}, 1993$

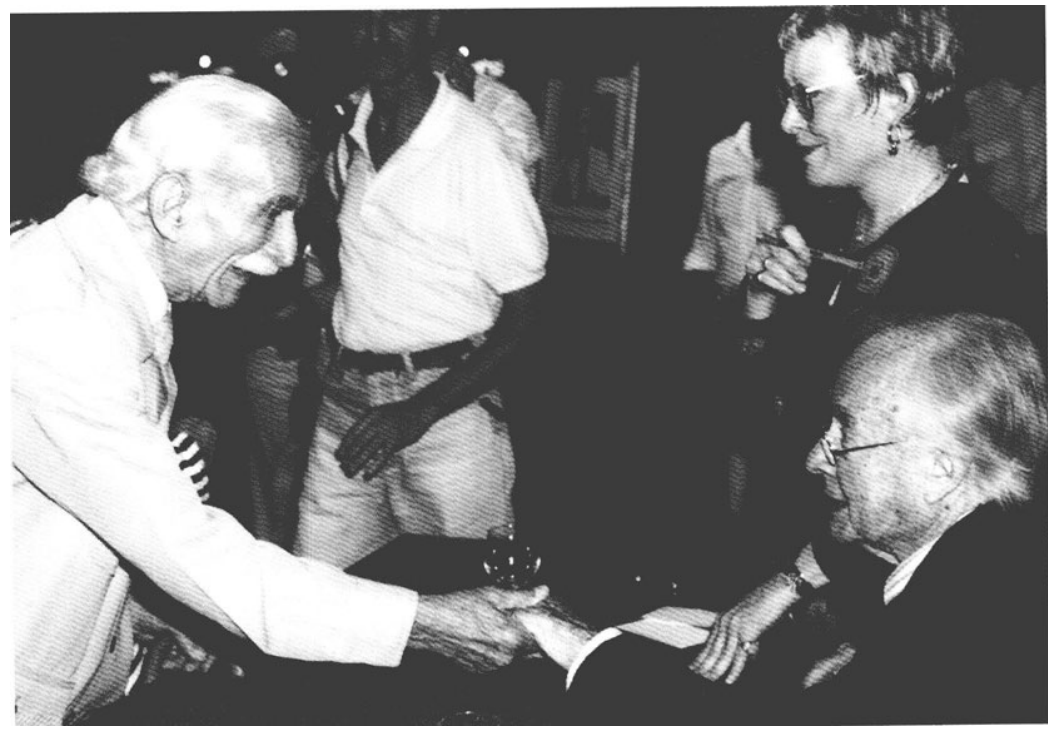

Haiti Moussatche, colega desde o estágio no Hospital Oswaldo Cruz e que, "discípulo de Miguel Ozório, cedo tonou-se cientista de invulgar prestígio". cumprimenta o autor que está acompanhado pela filha Ama Margarida. Lançamento do livro Mon pai, ABL, 1993

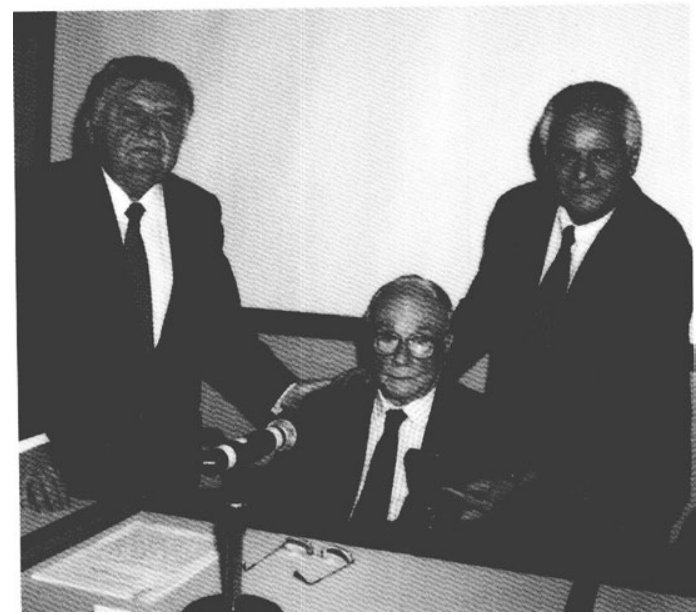

Presidente de Honra do Centenário da Fundação Oswaldo Cruz, ladeado por Elói de Souza Garcia, presidente da Fiocruz, e José Rodrigues Coura, diretor do IOC, após receber a Medalha Oswaldo Cruz concedida pelo Conselho Delibcrativo da Fiocruz, $1^{\circ}$ de outubro 1994) 
Quinto anjersário de formutura na Faculdade de Medicina 1936.

1)estaci-se, em pera aro contro, de óculos. Tito Leme Lopes. Ao seu bado.

Núlson Crraça Couto; xntado, de terno branco. liduardes Marques Tinoco c. ac tundo, de bigode, à dir. de Carlos Cladgas Filho. Anilcar de (antro.

"Tito associava à mteligencia rara uma cotracombirm capacidade distiticia e tmmis communicabilitade em que se confundiam sua bommia e gremerosidide.

Ficoul a) men lado ati morrer". 1938

Ministrando aula sobre ractiontividate na Univeridadc do Brasil, Pras Vermetha, cira 1940
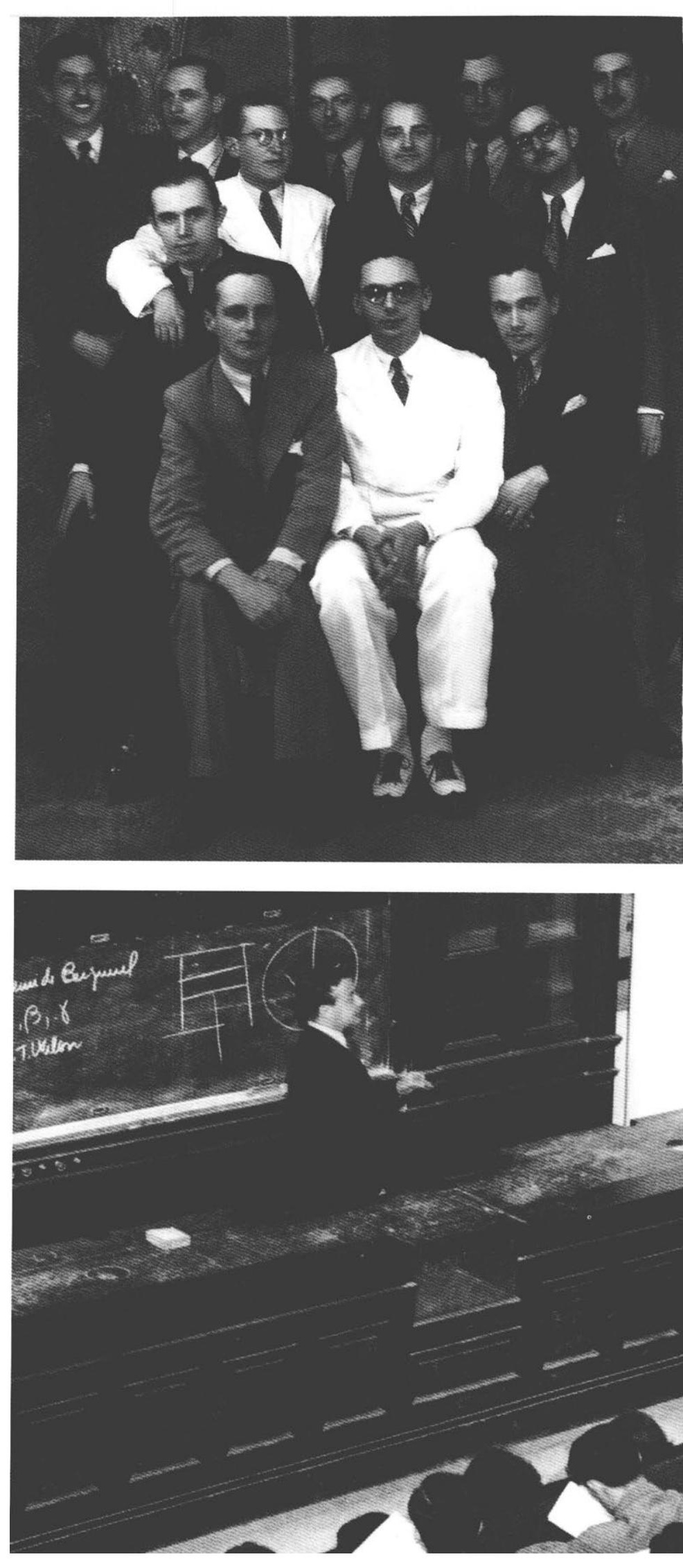


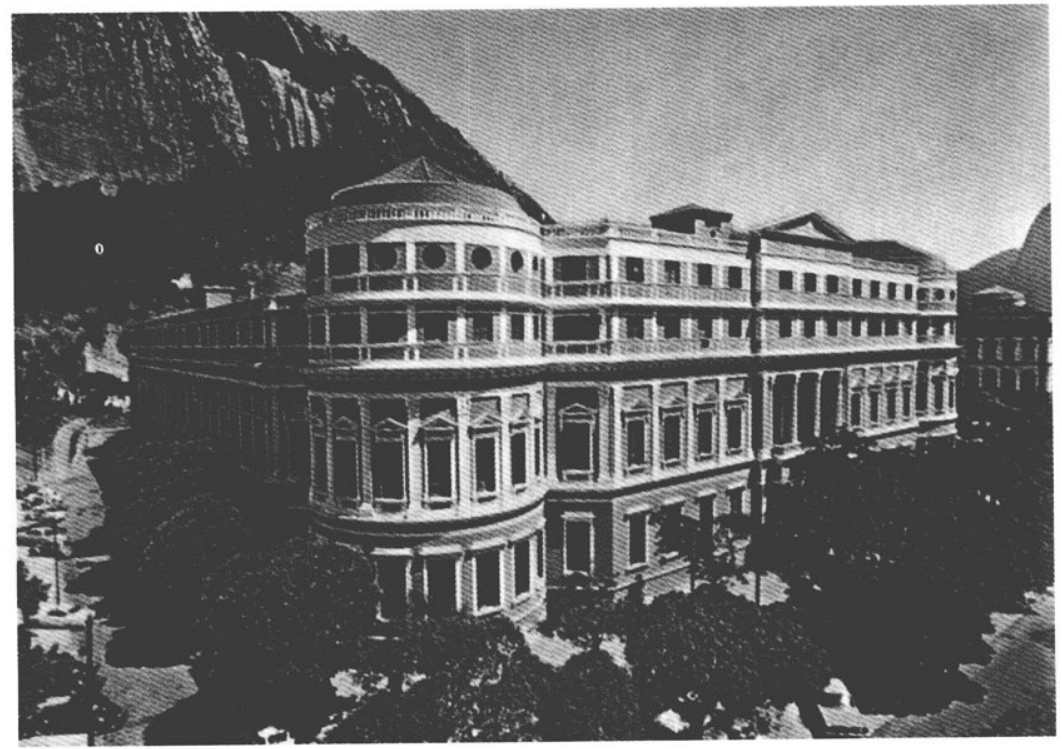

Faculdade de

Medicina da

Universidade do Brasil, "lindo a ameno edificio da l'r.ia Vermelha", que alorigava 0 Lnstituto de Biofisica, destruido na decadi de 1970). s./d.

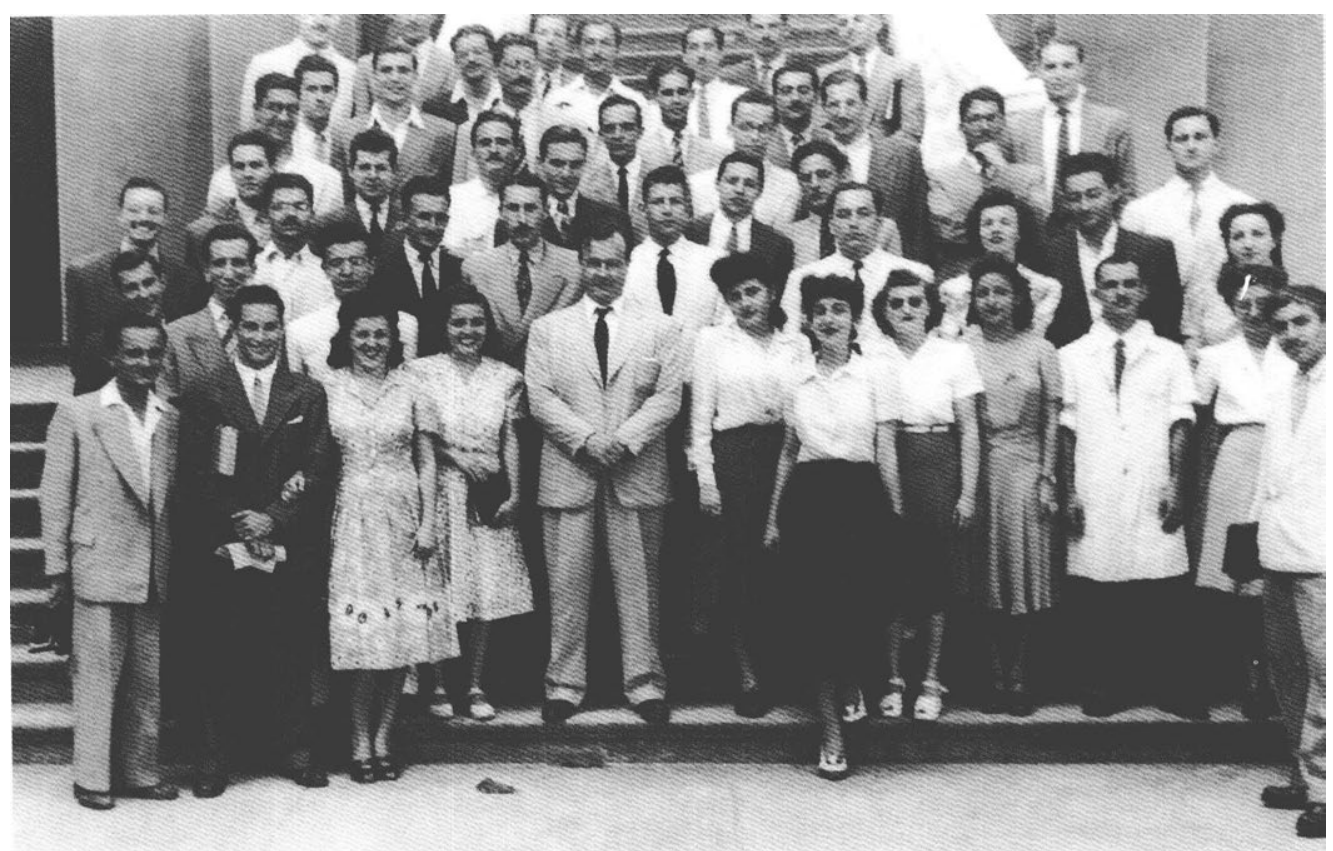

Carlos Chagals Filho com sua primejra turma de ahunos da Universiade do Brasil, 1938 


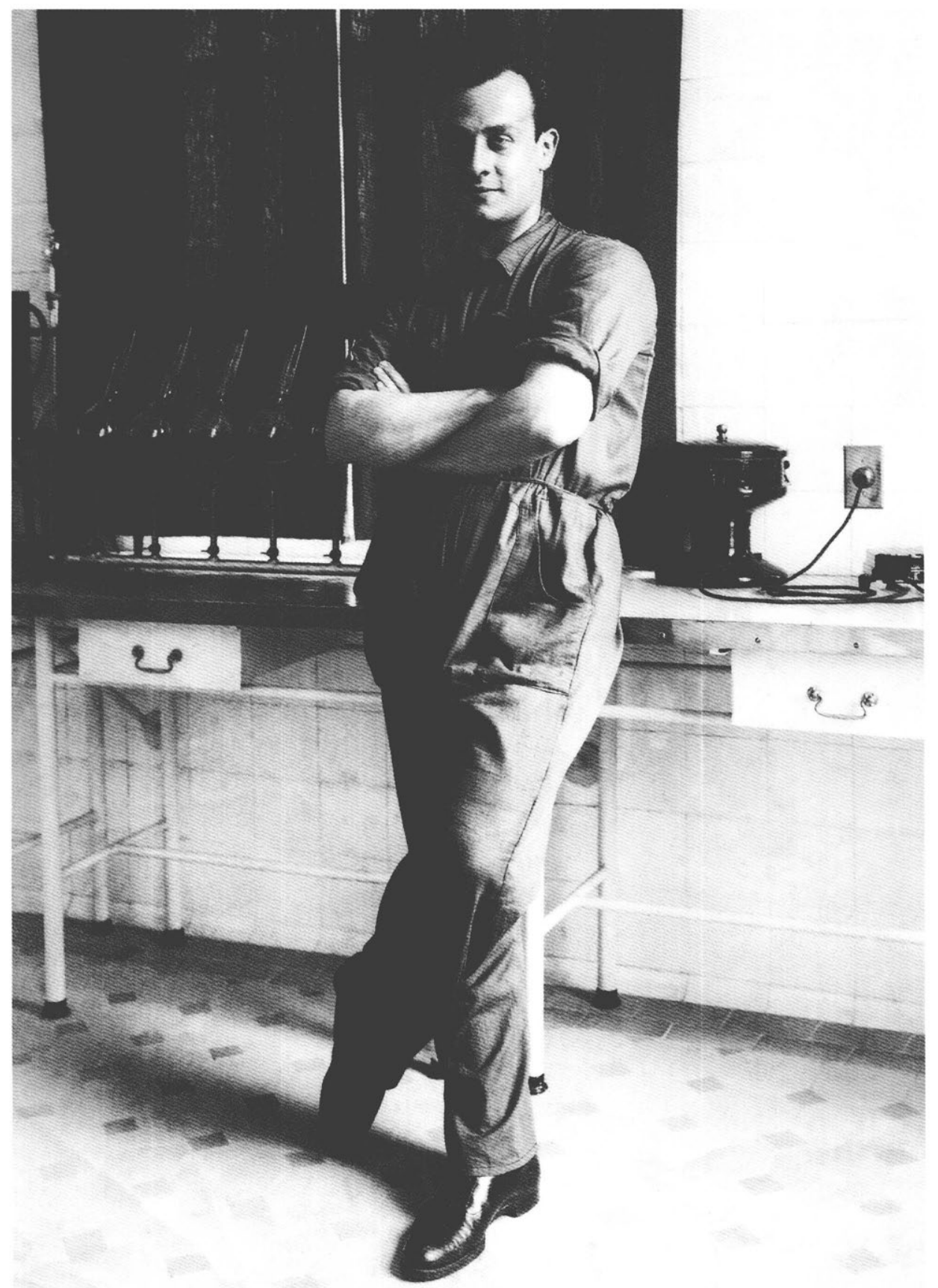

Primeiros passos do Instituto de Biofisica, na cadeira de fisica biológica, 19.38 
Realizando experiencia de cururizacion, com desnervaçăo parcial. 1961

No laloriatório de Aristides Azevedo P’alecos Lèos, devolridor d, depression alistrante que levai seu mome, "que texe deciviva intluincia na projeça (1) Instituto de Biofisica como insticuição de accelenci.,". Ao fundo, o) primeiro cletroencefalógr.ufo Crrass dhegado no Brasil, s./d.
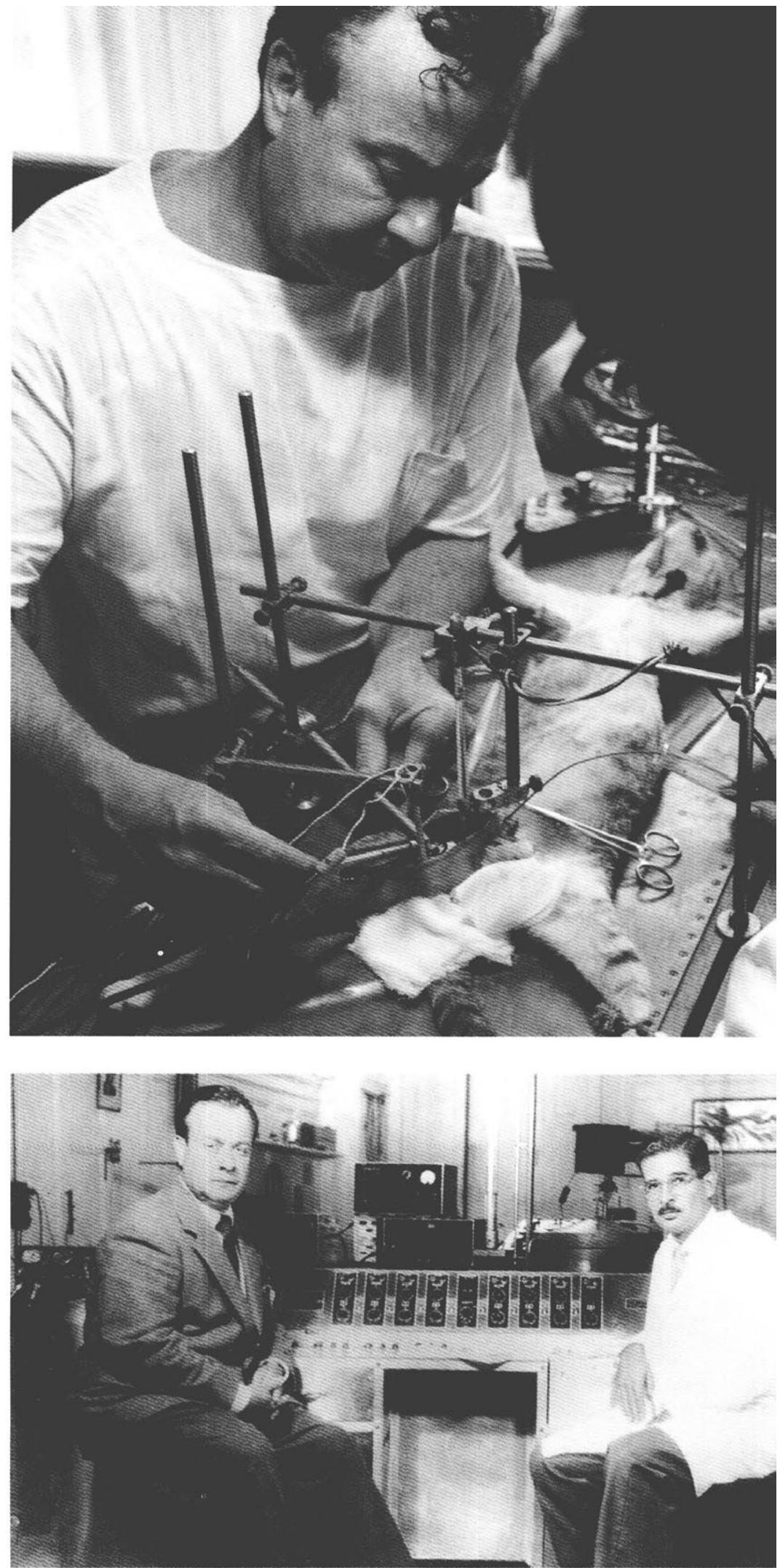


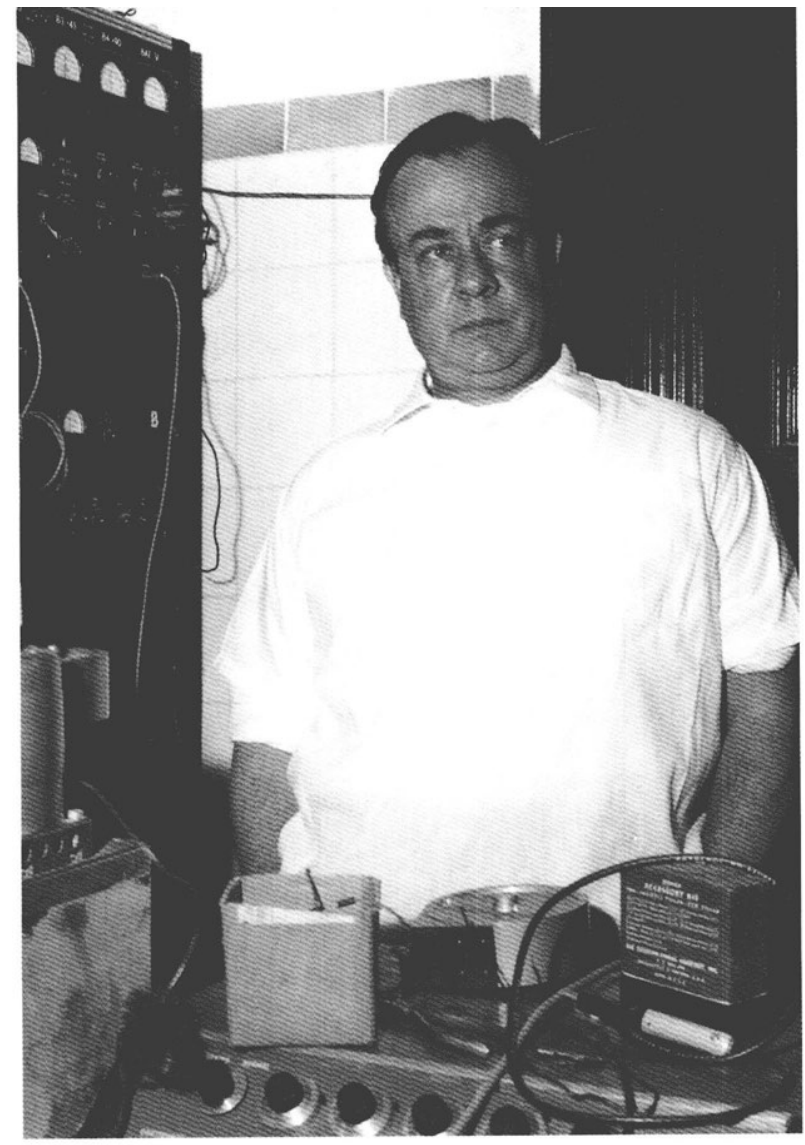

Posindo junto a equipamento de eletrofisiologia, 1957

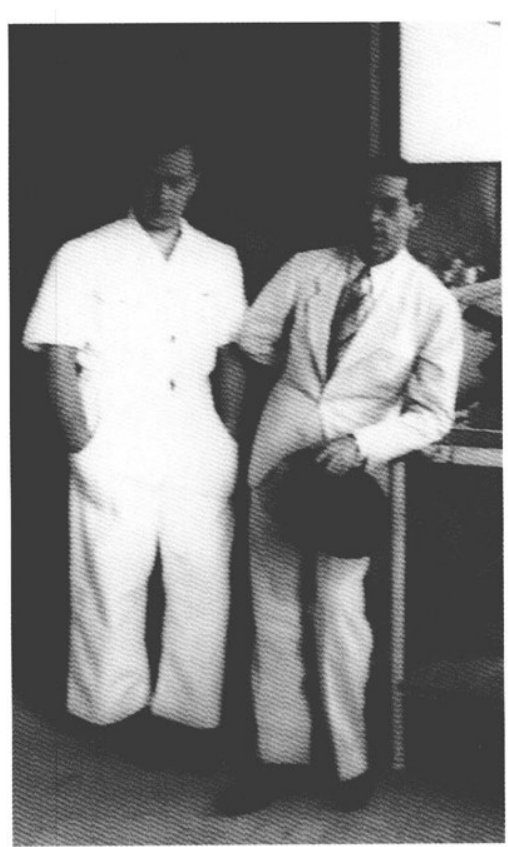

Joào Clemens Mactado, responsável pela instalaçào da primejra camara de cultura de tecidos e outros

equipanentos do lnstituto de Biofisica, cira 19+1)

Confraternizaça no Institute de Biofisica por ocasião do vigésimo quinto anversário da citedta di Universidade do Brasil, depois UFRJ. Carlos Chagas Filho c. doma Antah laderatos, da esce para a dir., por Albertes Hargreaves. Regina Feigl. benemérita do Institute de Biotisica, e Latiro Solero. 1\%2

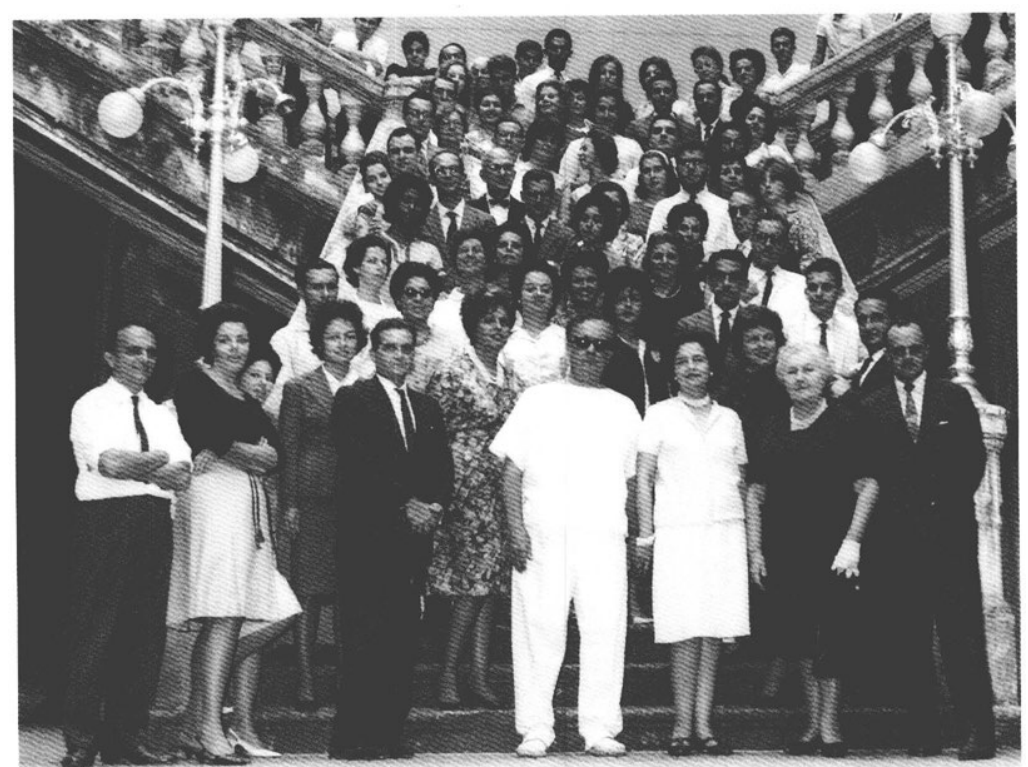




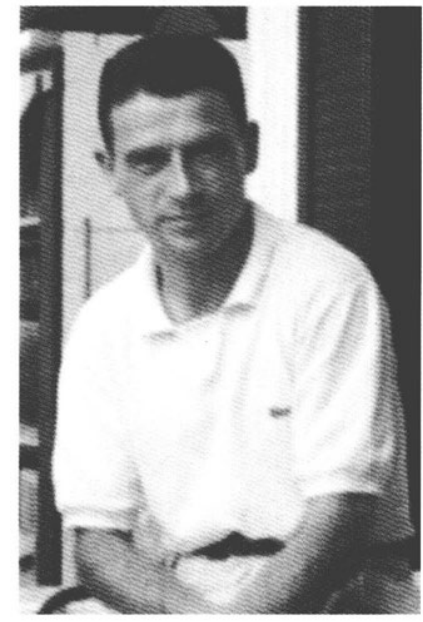

Raymond Latarjet, do Instituto Curic, trabathou em intima colaboração com Jacques Monod. Françọis Jacob e André Lwoff, do Instituto Pasteur, durante os primórdios da biologia molecular, e foi responsável peli criação do laboratório de radiobiologia do IBCC.F, desenvolvido sob a liderança de Luis Renato Caldas, seu estagiácios en Paris, s./d.

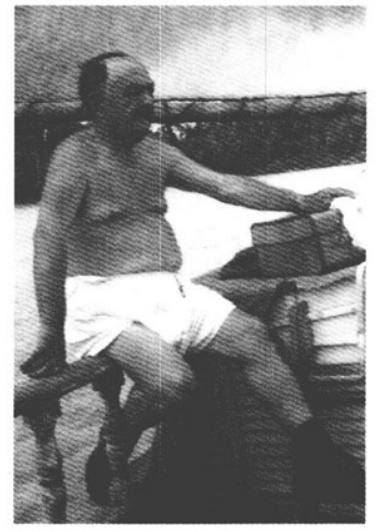

Bermardo Meiman, ictiologista amador. trazia do Amazomas peixes-elétricos que serviam de atraçio circense e passou a formectelos ao Instituto de Biofisica, s. $/$ d.

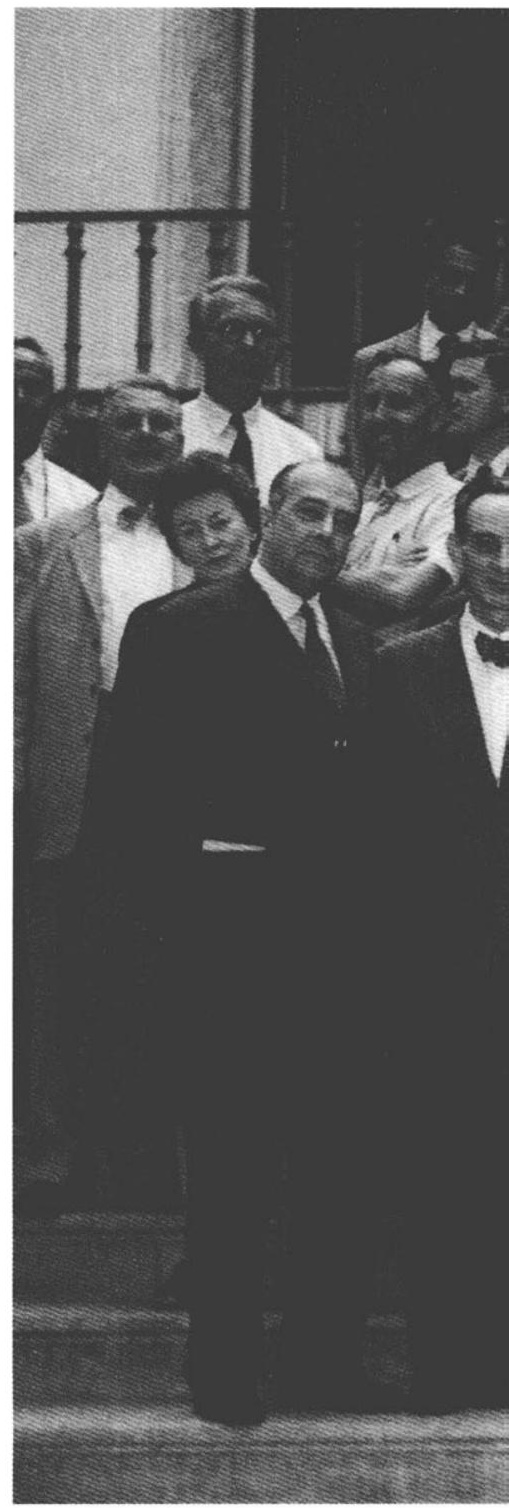




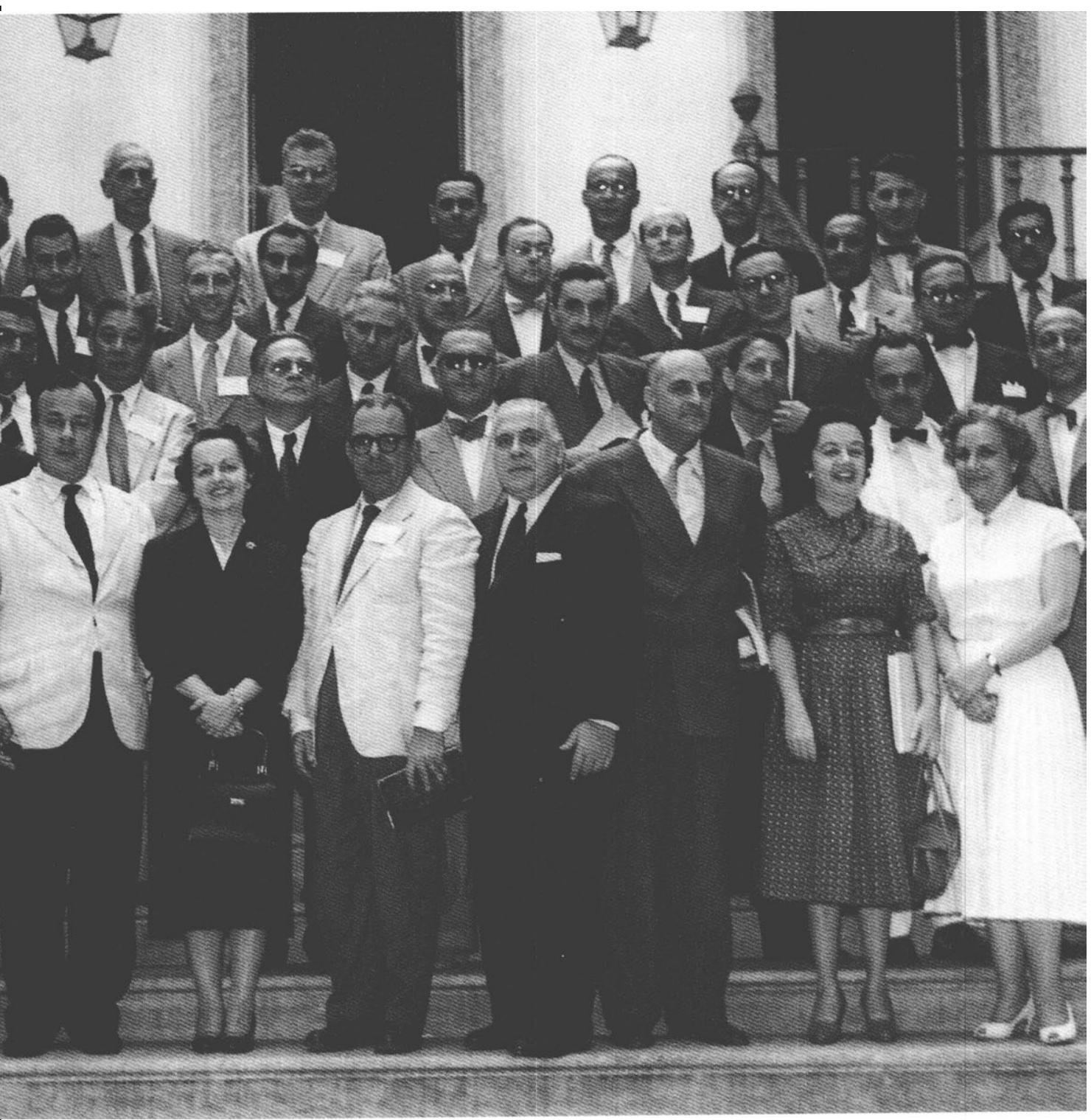

Participantes do Congresso sobre curare ce curarizantes. Destacam-se, na primeira fila, Daniel Bover (à esq. de C.C.F), Filomena Bovet-Nitti, Paulo de Carvalho, Aida Hasson e Denise Albe-Fessard. São identificados, ainda, Thales Martins (de óculos, atrás de FB-N), Lauro Solero (de gravata borboleta), tendo atrás, de cabeça reclinada, José Cândido de Carvalho. $\mathrm{Na}$ última fila, encostados ao corrinão esquerdo, Manoel da Frota Moreira (esq.) e Hiss Martins Ferreira (dir.) e, um pouco mais abaixo, de óculos, Lindon Brown. Museu Nacional, 1957 


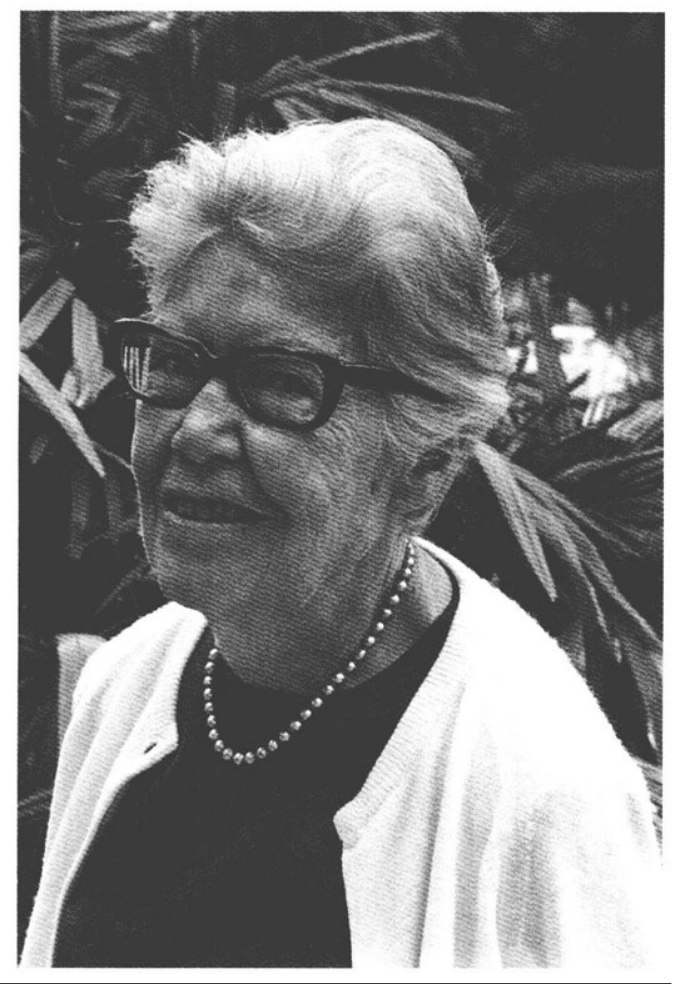

Hertha Meyer. Perseguida na Alemanha e Itália pelo nazi-fascismo, "desenvolveu notável atividade no instituto na formação de pesquisadores e trabalhos científicos, com destaque para sua contribuição na descoberta do Fator de Crescimento dos Nervos (NGF), que deu o Prêmio Nobel a Rita Levi-Montalcini, s./d.

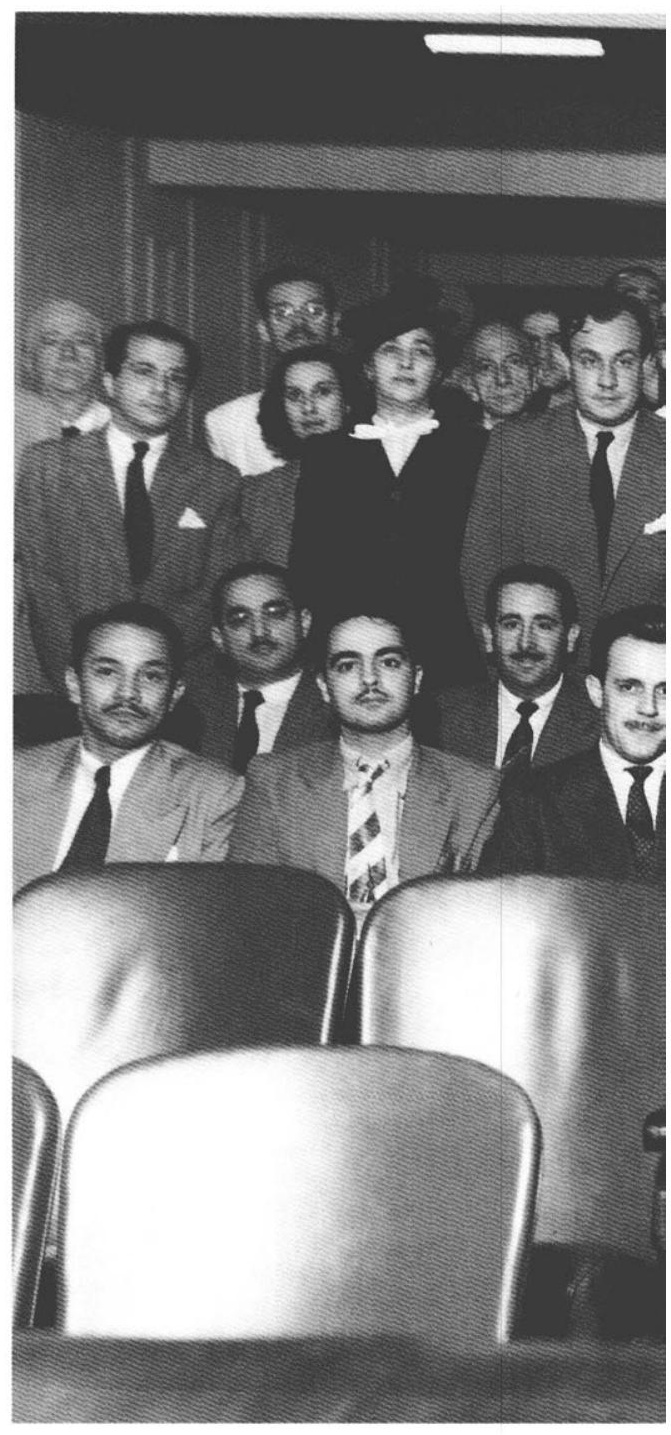




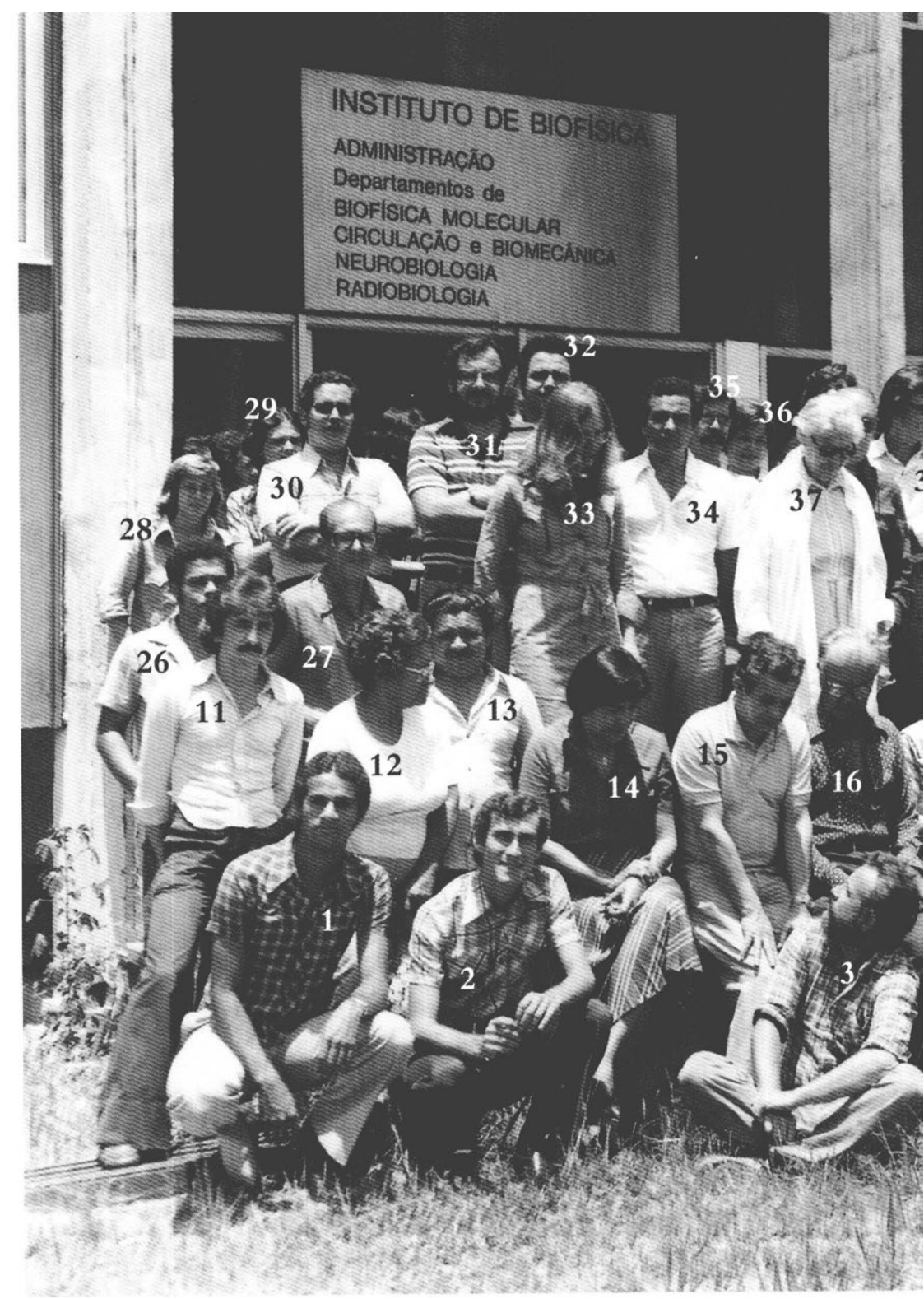

(irupe de professores, alumos e funcionírios do Sustituto de Biofisica, na llha do fundio. décarda de 1971)

1 - Nào identificado

2 - Mauricio Tecles

3 - Corlos Eduario Rocha Mirmda

4 - liernando Ciarcia de Mello

亏 - Edson Rondinelli

6 - Eduardo Oswaldo Cruz

7 - Woltgang Feiffer

8 - Nìo identiticado

9 - Major Roberto Oscar Brasil

1i) - Raul Dodsworth Machado
11 - Sebastico Cruz

12 - Rachel dos Reis Soares

1.3 - Antonio Lisboa de Oliveira

14 - Leny Cavalcanti

15 - Maury Miranda

16 - Carlos Chagas Filho

17 - Não identiticado

18 - Técia Maria Ulisses de Carvalho

19) - Nào identiticado

20) - Clarisse Oliveira Reges

21 - Eduardo Penta Franca

22 - Thais Penna Barhosa de Souza

2.3 - Aglai Venna Barbosa de Souza 


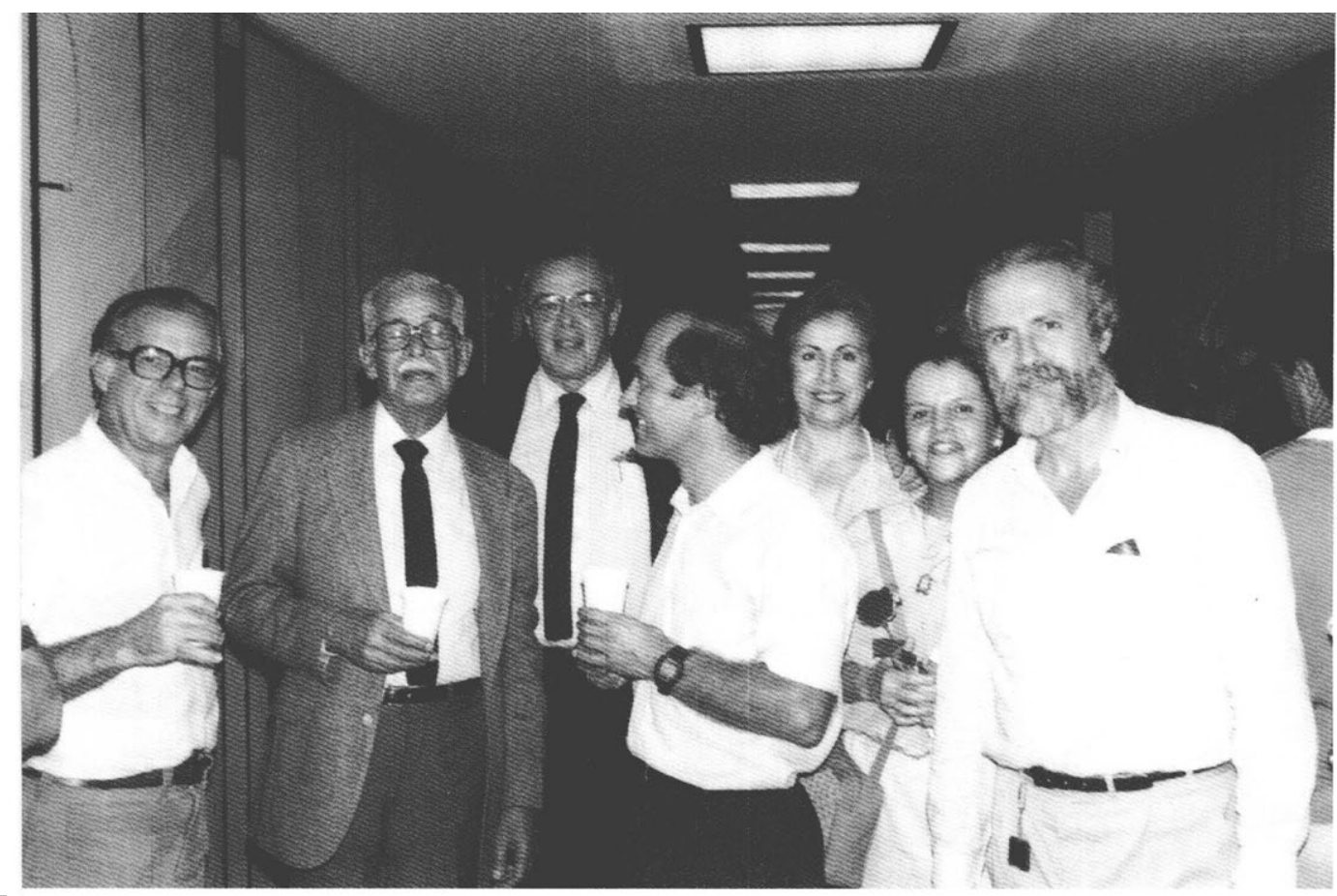

Comemoracào no LBCC.F dos setenta anos de Aristides Lèo.

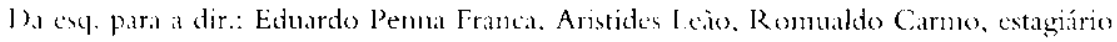
ttaliane do departamento de neurobiologia. Leda Camo, Elizabeth Raja Cabaglia L eăo c Carlos Feduardo Rocha Miranda, 19st

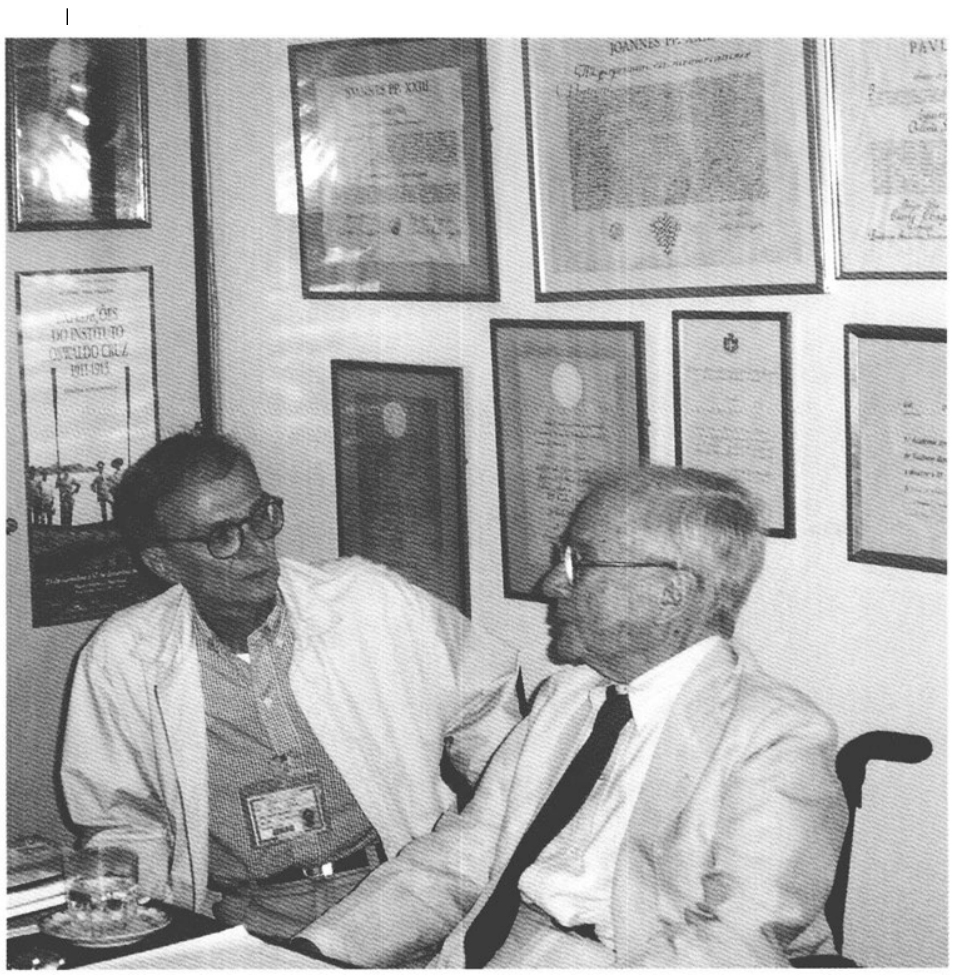

Cim 1)arcy

Fontoura de

Almeida, "ilustre pesquisador que me acompanlua. tielmente, desde o inícios de minlia atividade", no gabinete do Instituto de Biotísica, 1995 


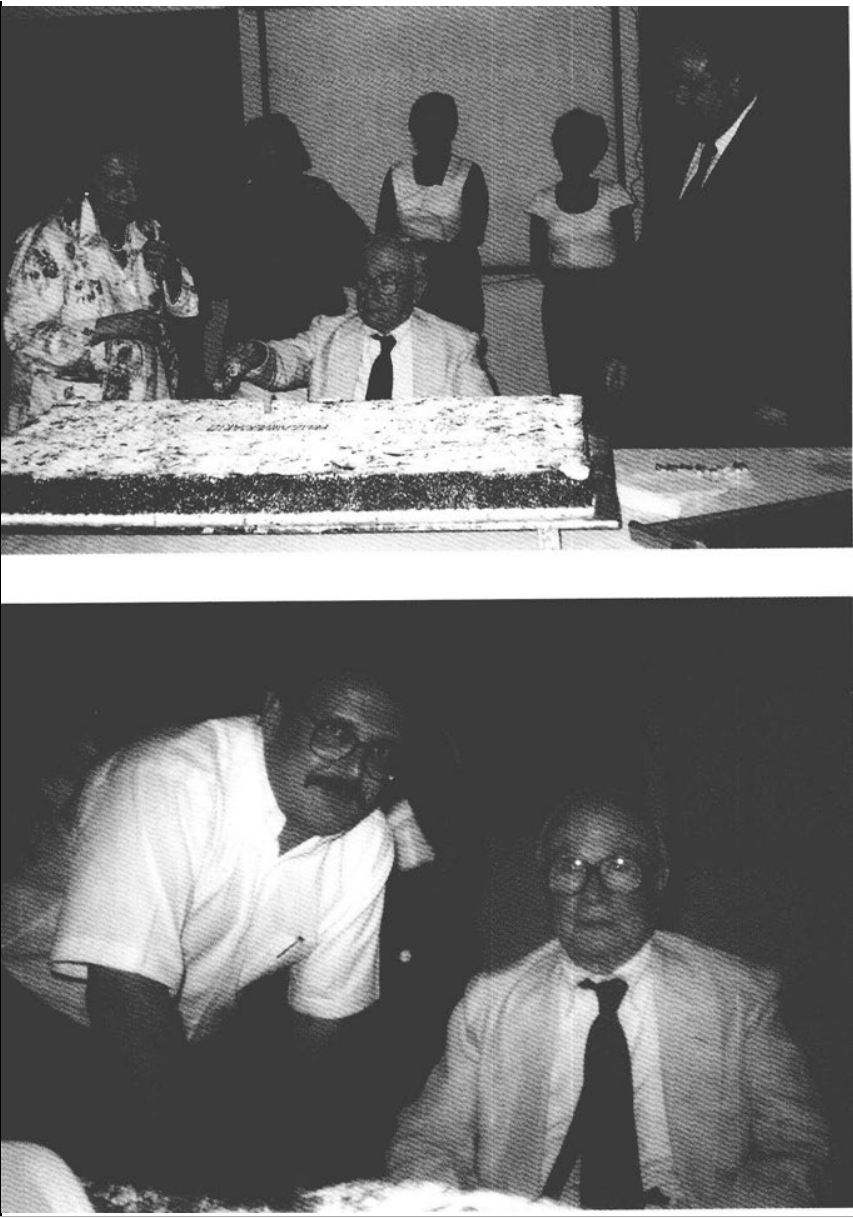

Com Antônio Carlos Campos de Carvalho, diretor do IBCCF a partir de 1998. Aniversário de oitenta anos, 1990
Festa de aniversário no Instituto de Biofisica. Em primeiro plano, dona Annah e Gilberto Oliveira Castro, diretor do IBCCF, 1995

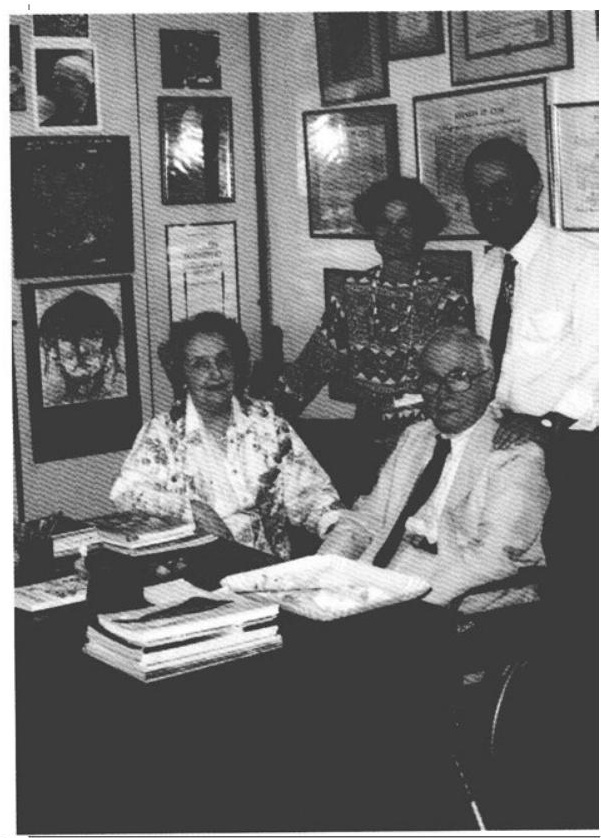

O casal Carlos Chagas Filho com padre Anib Gil Lopes e Maria Luiza de Almeida, 1995

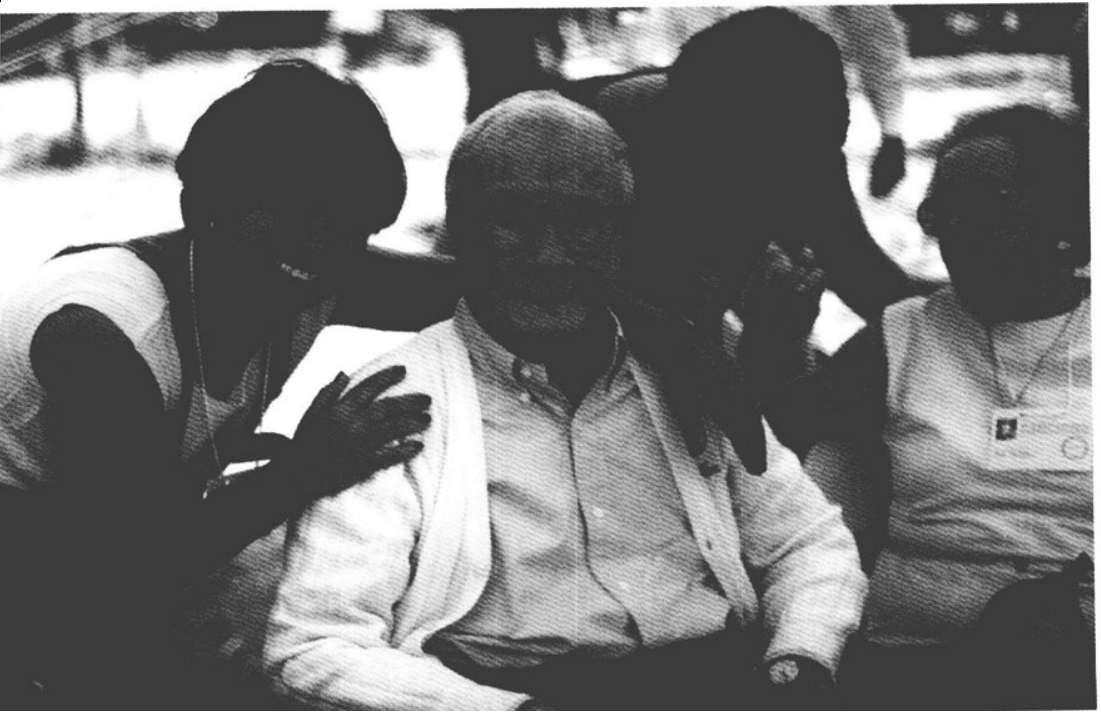

Carlos Chagas

Filho em sua

última celebração

de final de ano,

no Instituto de

Biofisica.

À esq., Sandra

Maria de Brito

Oliveira e, à dir.,

Aida Hasson

Valoch,

17 de dezembro

de 1999 
To Carlos Chagas

who brought

phulosofly \& Science,

science to philosoply,

stastemanshif t foth,

and the warmth of human fellowshipe,

ts the preoccupationt of the mind.

Pene' Dabos

Depoimento de René Dubos, ilustre bacteriologista francês.

Livro de homenagem pela celebração dos vinte e cinco anos de cátedra (1937-1962) 
Carlos chagas has setan example tous all as a scholar, a sacutitr statesmen, a tacher, auba patrizt. Cinsaios always that saence is an international enterpuse, he has been determined to ensure that Brasil shared make ha oun poprotional centribution to the world's storehonfe of saentitiz knowledge - anstre himsely is repmsible for much ofit, as a scientest of rare imagination, skill, patience and integity.

The success and devition or his pupils Qive then oun endence of Corlos Chagas' prowers as a teachen, aud the sciauticiz ared quereraly has cause to be quakefue to him as me pits grat statesmen. The Uuwatity of Runil has exuy reason toke prowd of Carlos Chagas. Loutom Sept 1962

P.B Meowar

Depoimento do Prêmio Nobel Peter Briand Medawar, fisiologista inglês. Livro de homenagem pela celebração dos vinte e cinco anos de cátedra (1937-1962) 


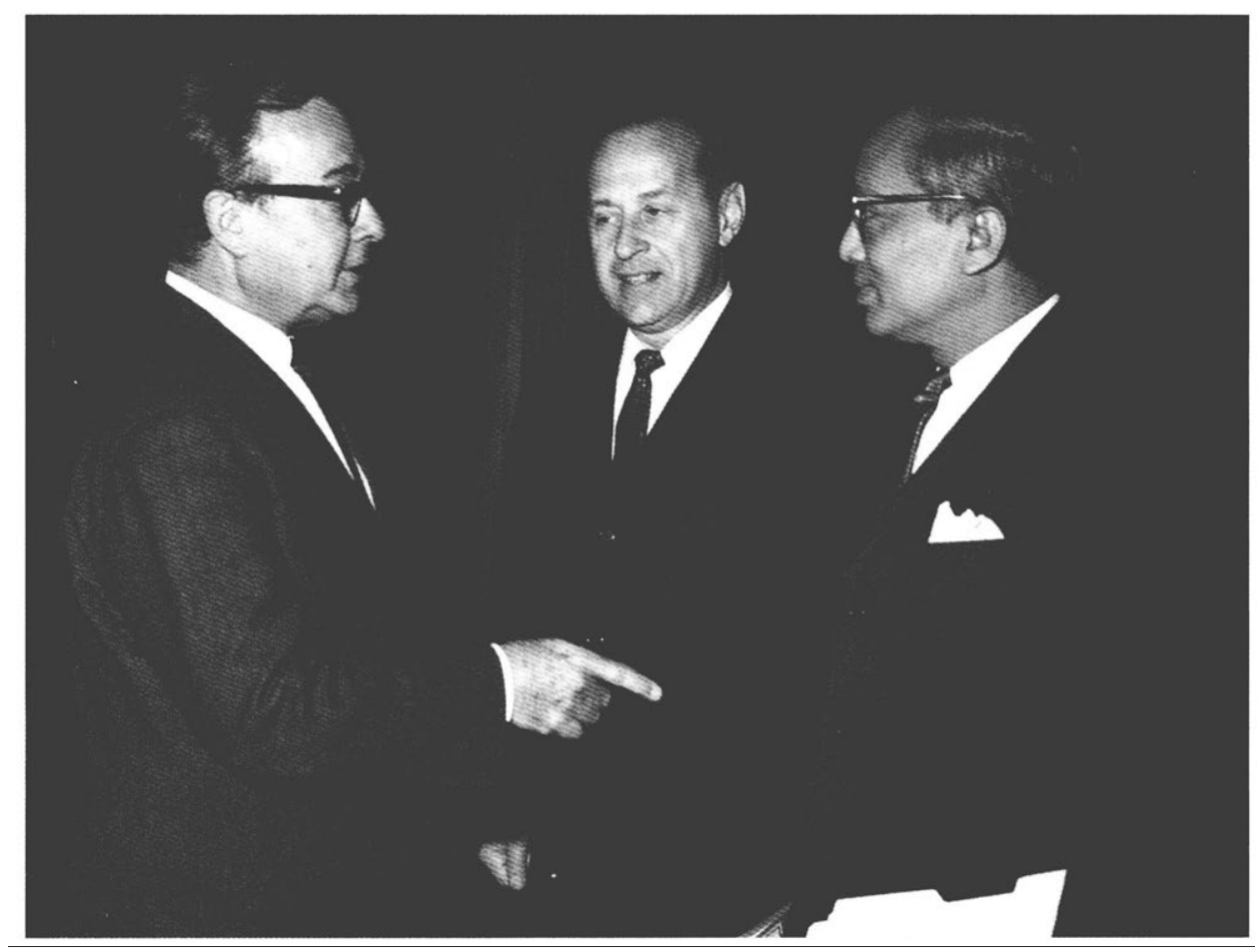

Carlos Chagas Filho, secretário-geral da Conferência das Nações Unidas para a Aplicação da Ciència e da Tecnologia do Desenvolvimento, com Phillipe Deseynes e U Thant (de óculos), secretário-geral da ONU, "uma pessoa extremamente agradável, com quem se podia ter uma compreensão mútua no prineiro momento", 1964

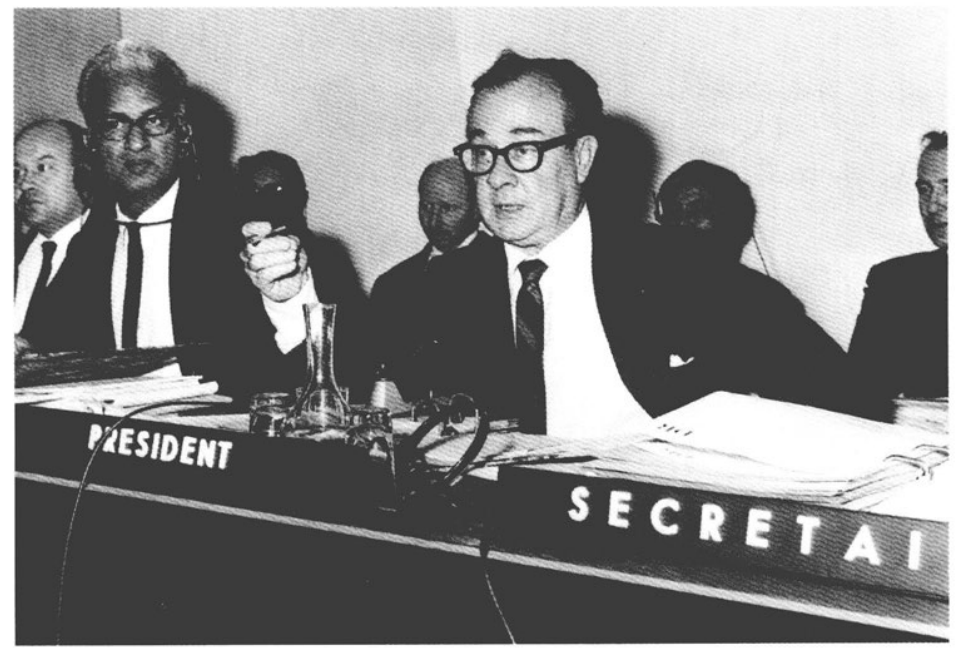

Carlos Chagas Filho preside sessão inaugural do Comitè de Estudos para a Aplicaçio da Ciência e da Tecnologia ao Desenvolvimento, 1964 

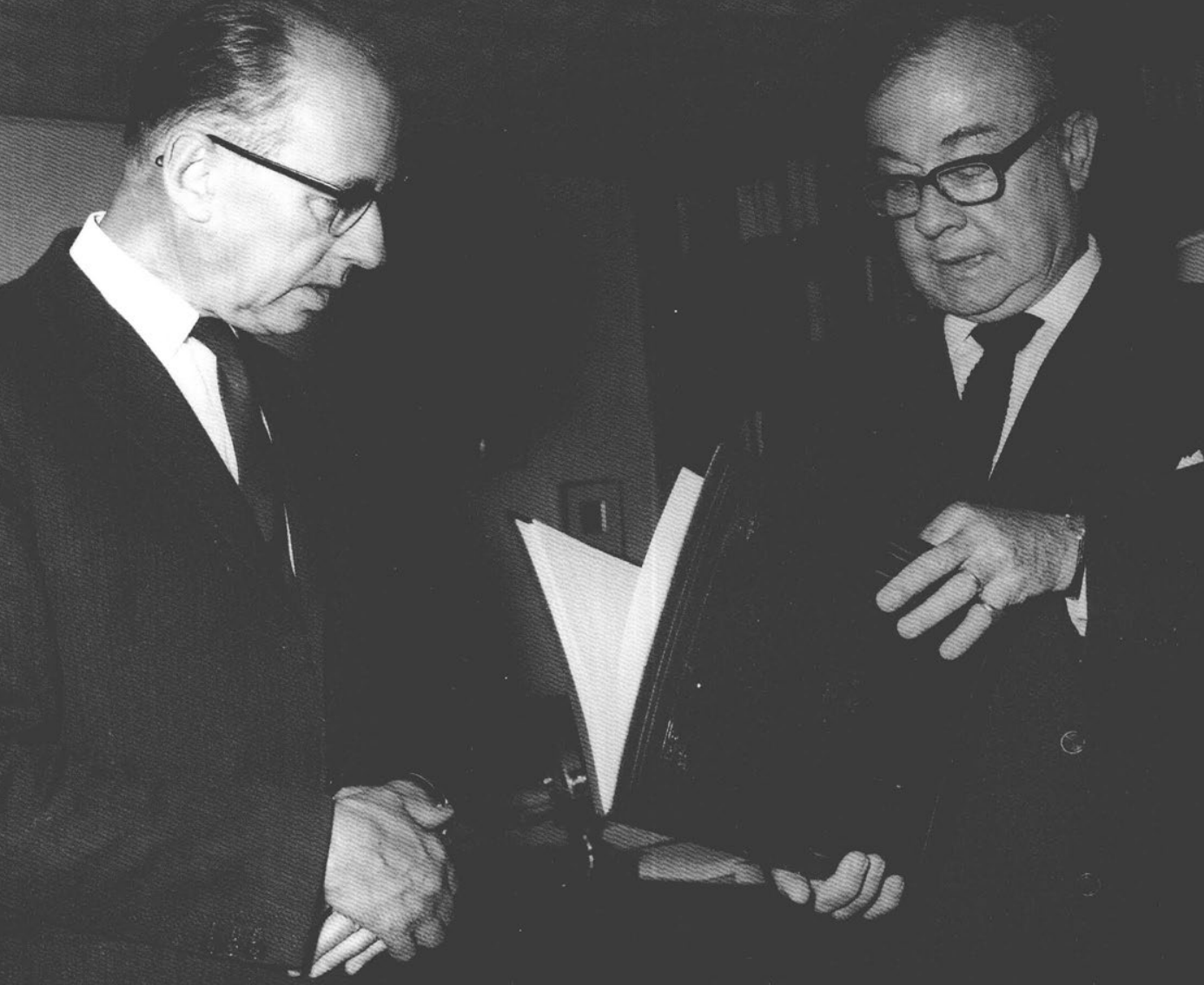

Com René Maheu, dirctor geral da Unesco, 1967 
Dentor Homoris (ilus dia Universidate de Coimbra. $\dot{A}$ ere... de ixculus, o combrasader de

l'ortugal no Brasil. Rocheta. 1960
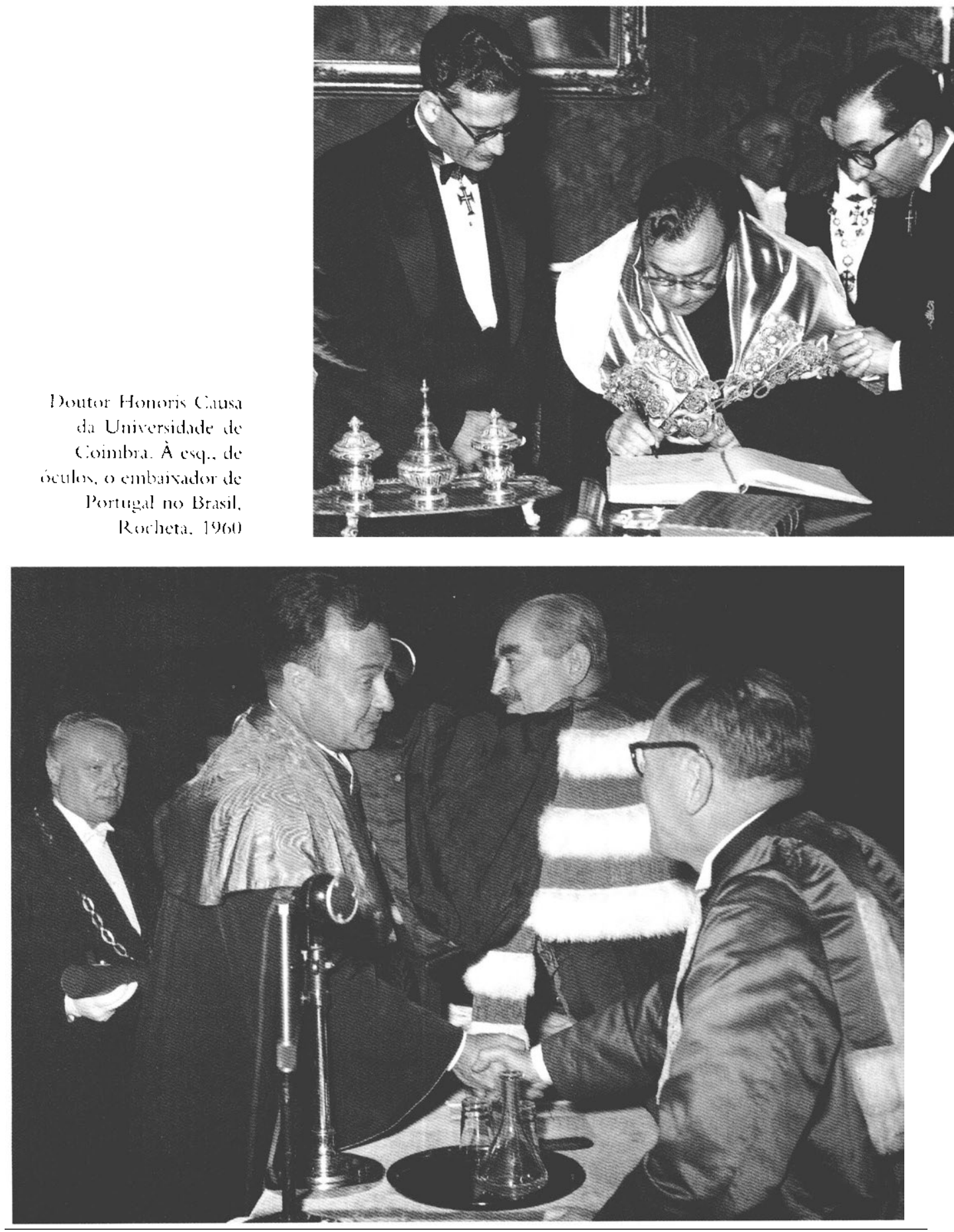

1)outor Honoris Catsa pela Universidade de Paris, comprimentado pelo reitor Jean Sarraihl. Ao fundo, o doyen Binet, Sorbonne, Paris, 1954 


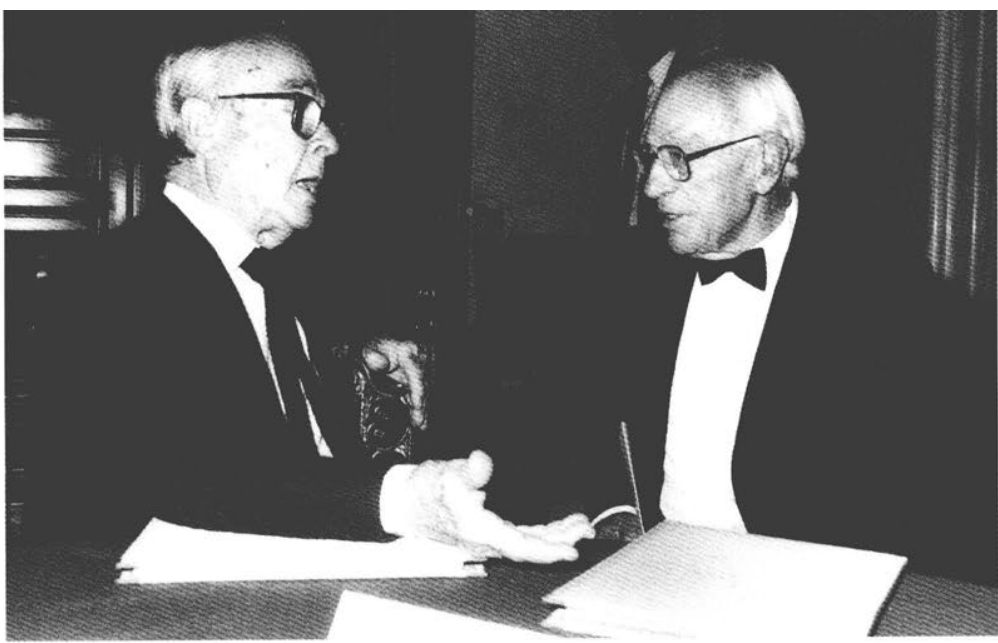

Carlos Chagas Filho com John Eccles, Prêmio Nobel de Fisiologia e Medicina de 1963 por seus trabalhos sobre mecanismos iônicos na transmissão de impulsos nervosos. Membro da Academia Pontificia de Ciências, participou de vários eventos do Instituto de Biofísica. Entrega do Prêmio Fiuggi, Valle d'Aosta, 1987

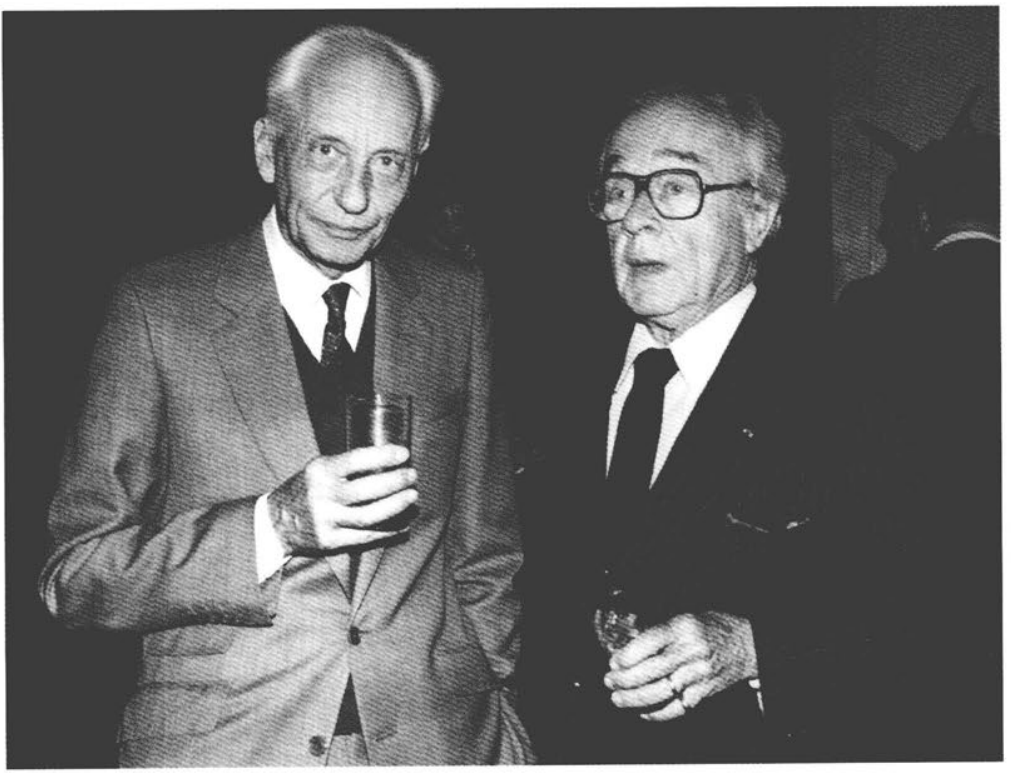

Carlos Chagas Filho com Jean-BaptisteGabriel-Joachim Dausset, Prêmio Nobel de Fisiologia e Medicina de 1980 por seus trabalhos sobre as bases genéticas da reação imunológica, durante Jomada Franco-Brasileira, 1985

Rita Lévi-Montalcini, Prêmio Nobel de Fisiologia e Medicina de 1986. Seu ingresso na Academia Pontificia de Ciências, a convite de Carlos Chagas Filho, simboliza, por sua condição de mulher e sua origem judaica, a ampliação do espectro ideológico e cultural do corpo de acadêmicos da APC, 1972 


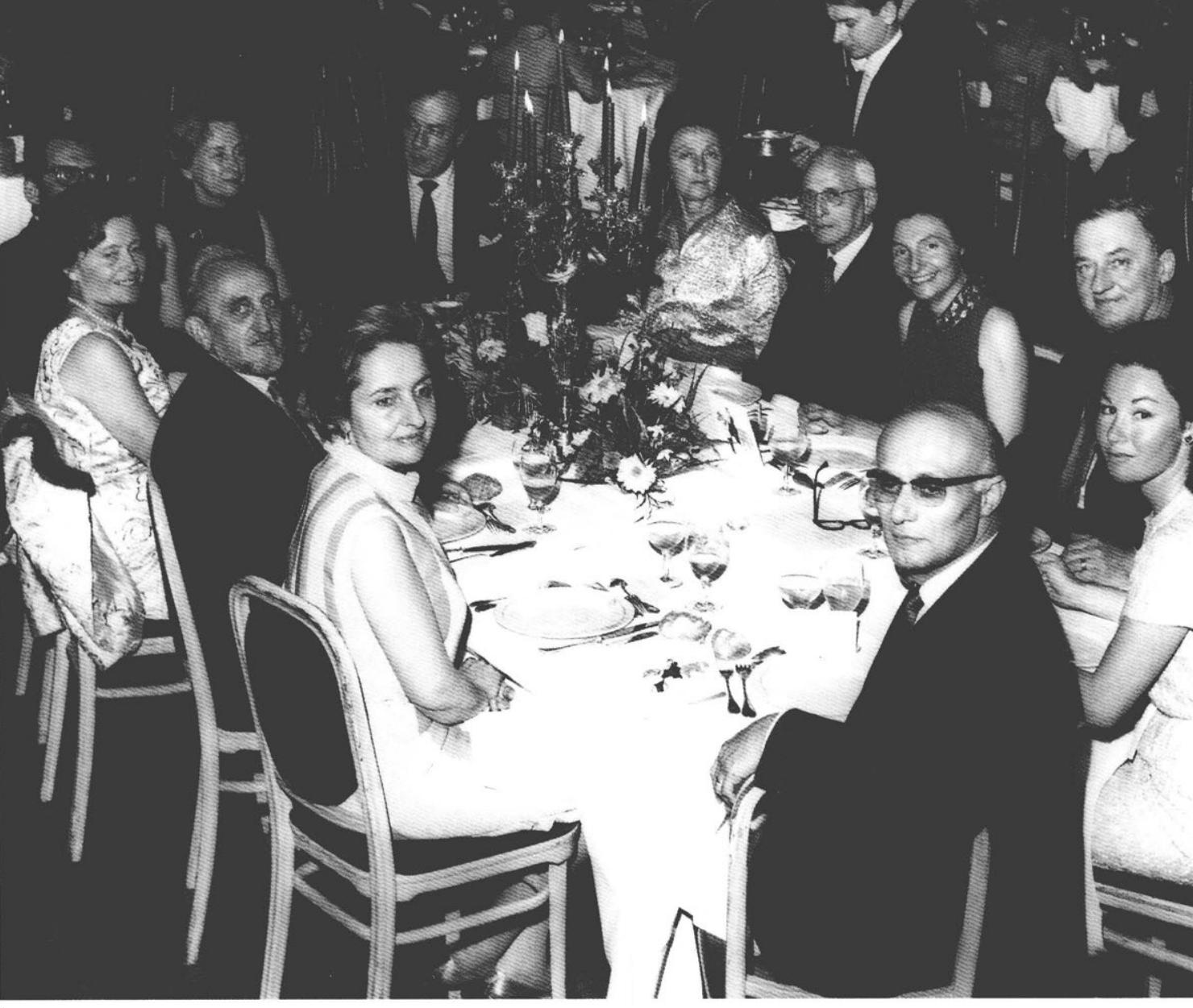


Jantar com

Jean Perrin (ao lado de dona Annah), criador do CNRS, modelo para a criação do $\mathrm{CNPq}$, com a presença de René Wurmser (ao fundo, de óculos) e sua esposa Sabine (na cabeceira, ao lado de $\mathrm{CCF}$ ). "A contribuição do casal Wurmser ao nosso desenvolvimento é incalculável.

Partilharam conosco todos os problemas e nos ajudaram a vencer vicissitudes". Paris, década de 1960

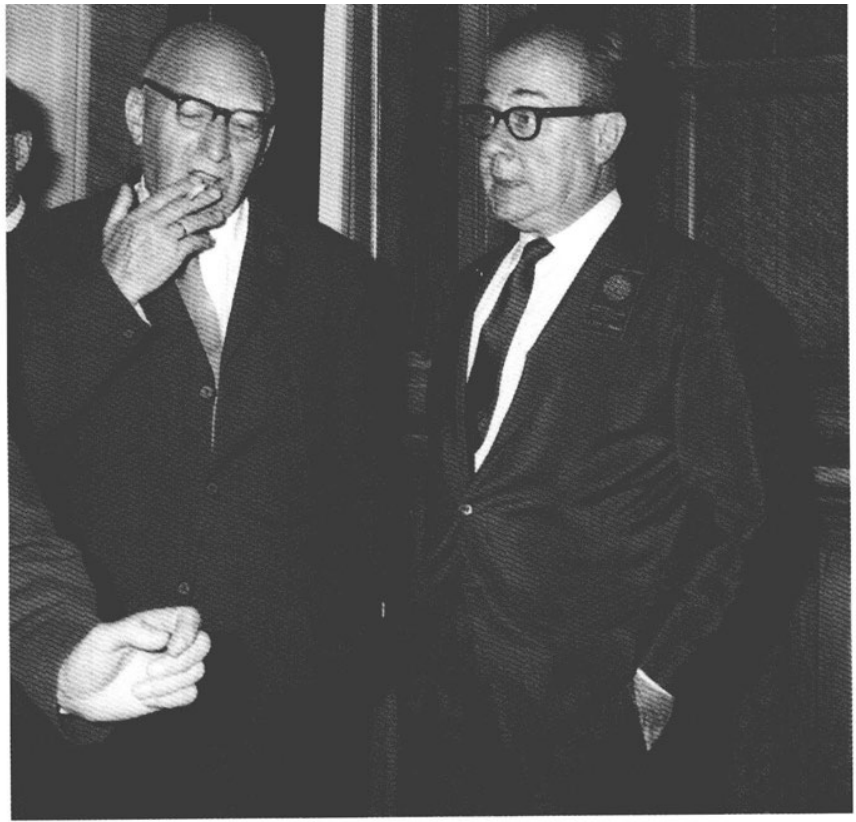

Com Corneille Jean François Heymans, Prêmio Nobel de Fisiologia e Medicina de 1938 pela elucidação de mecanismos regulatórios da respiração e membro da Academia Pontificia de Ciências. Recebeu em 1943 o Prêmio Pio XI outorgado pela Academia. Em visita ao Instituto de Biofisica, s./d.

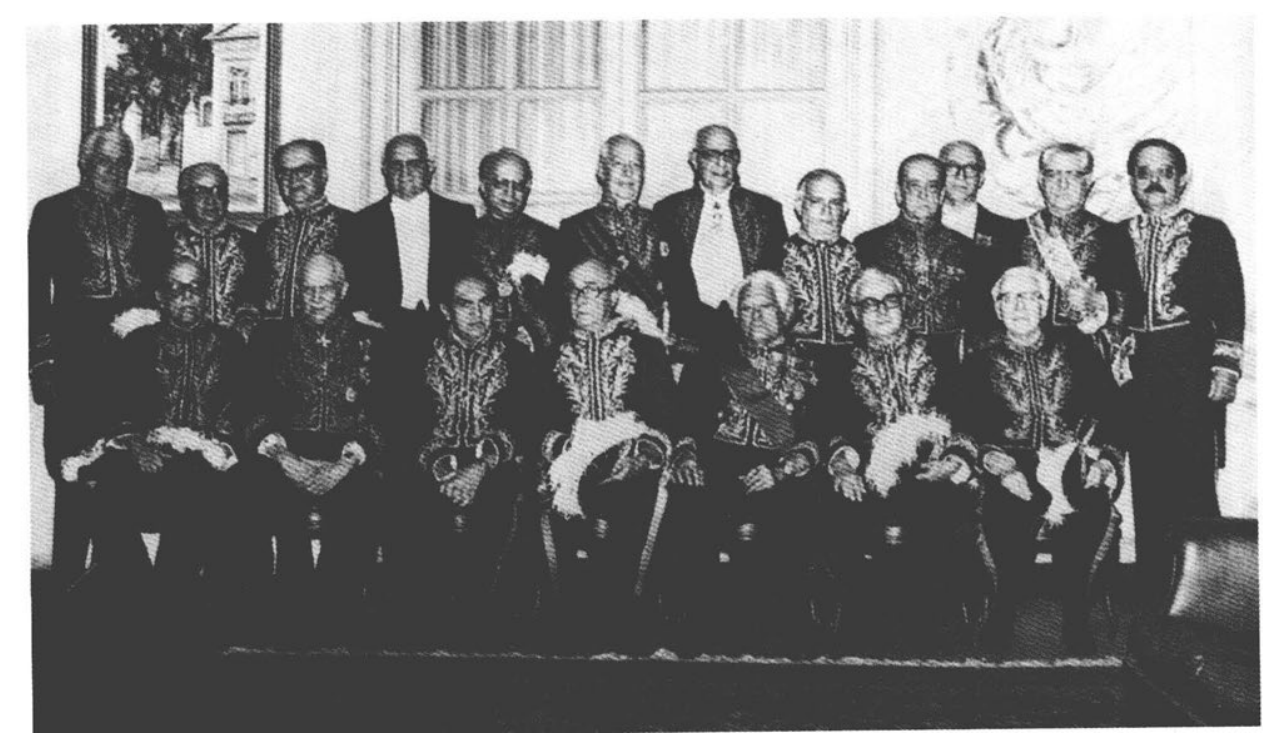

Posse na Academia Brasileira de Letras. Sentados, da esq. para a dir.: Cândido Mota Filho, Peregrino Júnior, Odylo Costa, filho, Carlos Chagas Filho, Austregésilo de Athayde, Francisco de Assis Barbosa e Ivan Lins. De pé: Luis Viana Filho, Genolino Amado, Hermes Lima, Barbosa Lima Sobrinho, Josué Montello, Pedro Calmon, Alceu Amoroso Lima, Otávio de Faria, Elmano Cardim, Américo Jacobina Lacombe (eleito, mas ainda não empossado), Afonso Arinos de Melo Franco e Herberto Sales (ABL, Elogio de Marques Rebelo, Rio de Janeiro, Livraria São José, 1974), 23/04/1974 


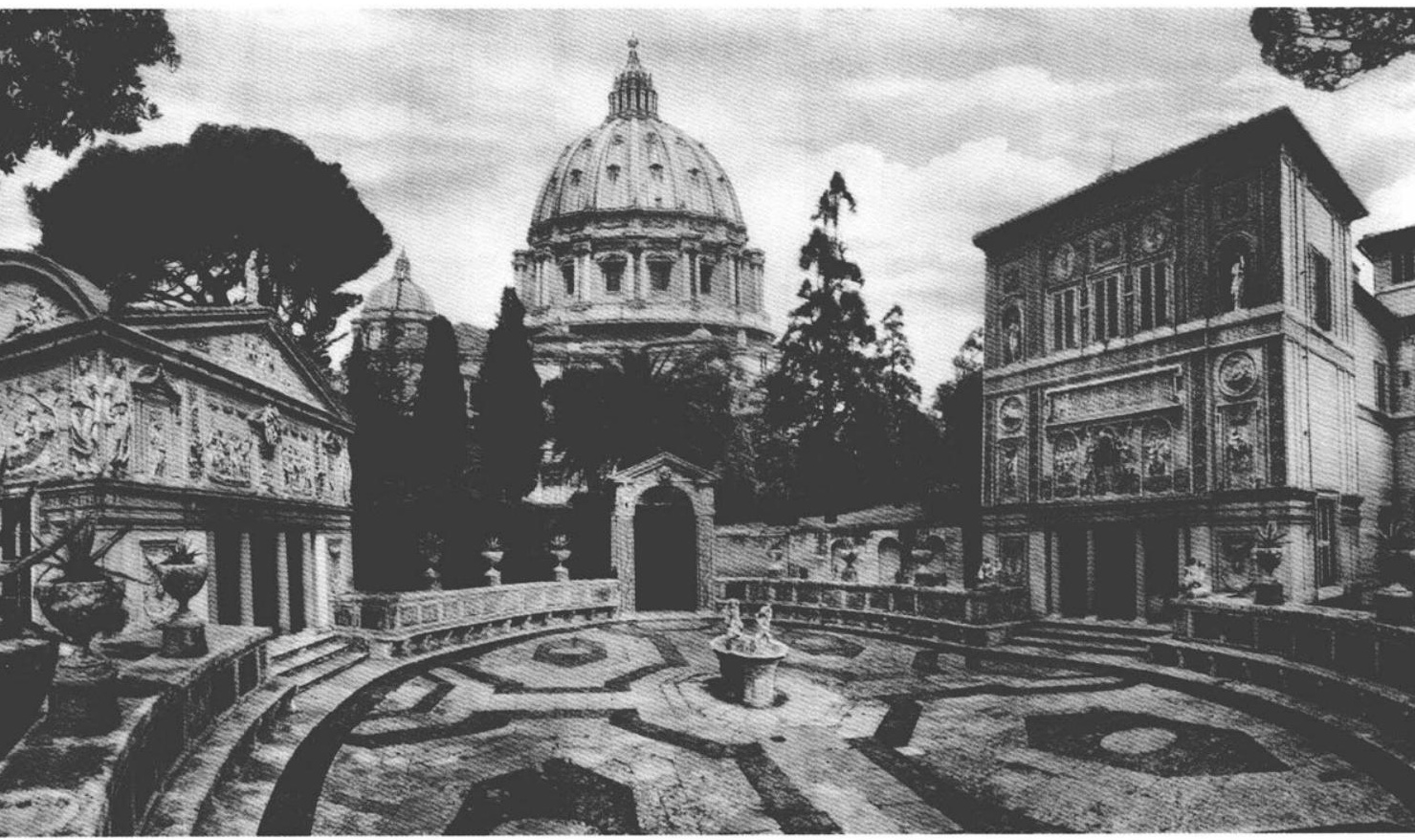

Casina Pio IV, no Vaticano, sede da Academia Pontificia de Ciências, s,/d.

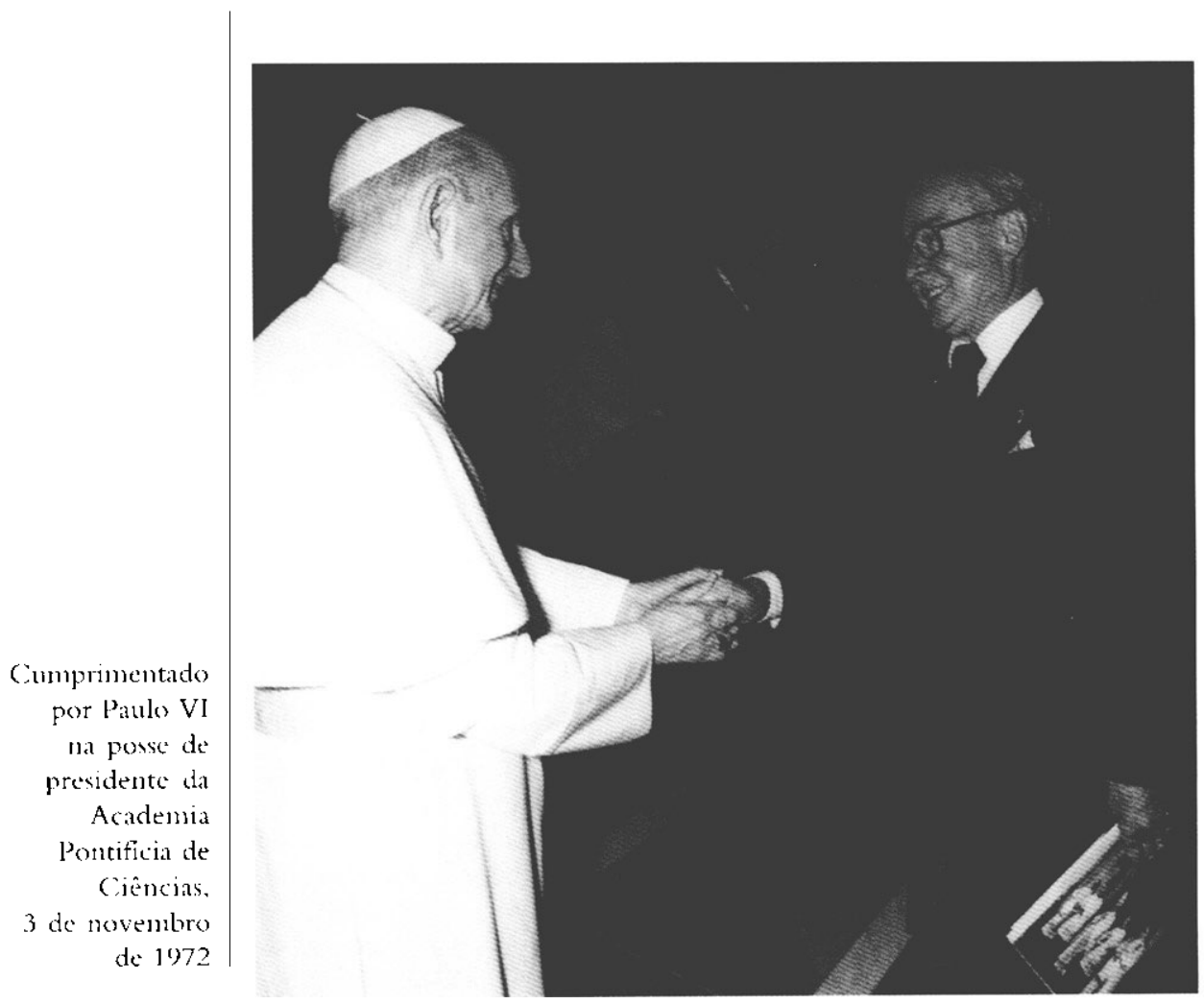




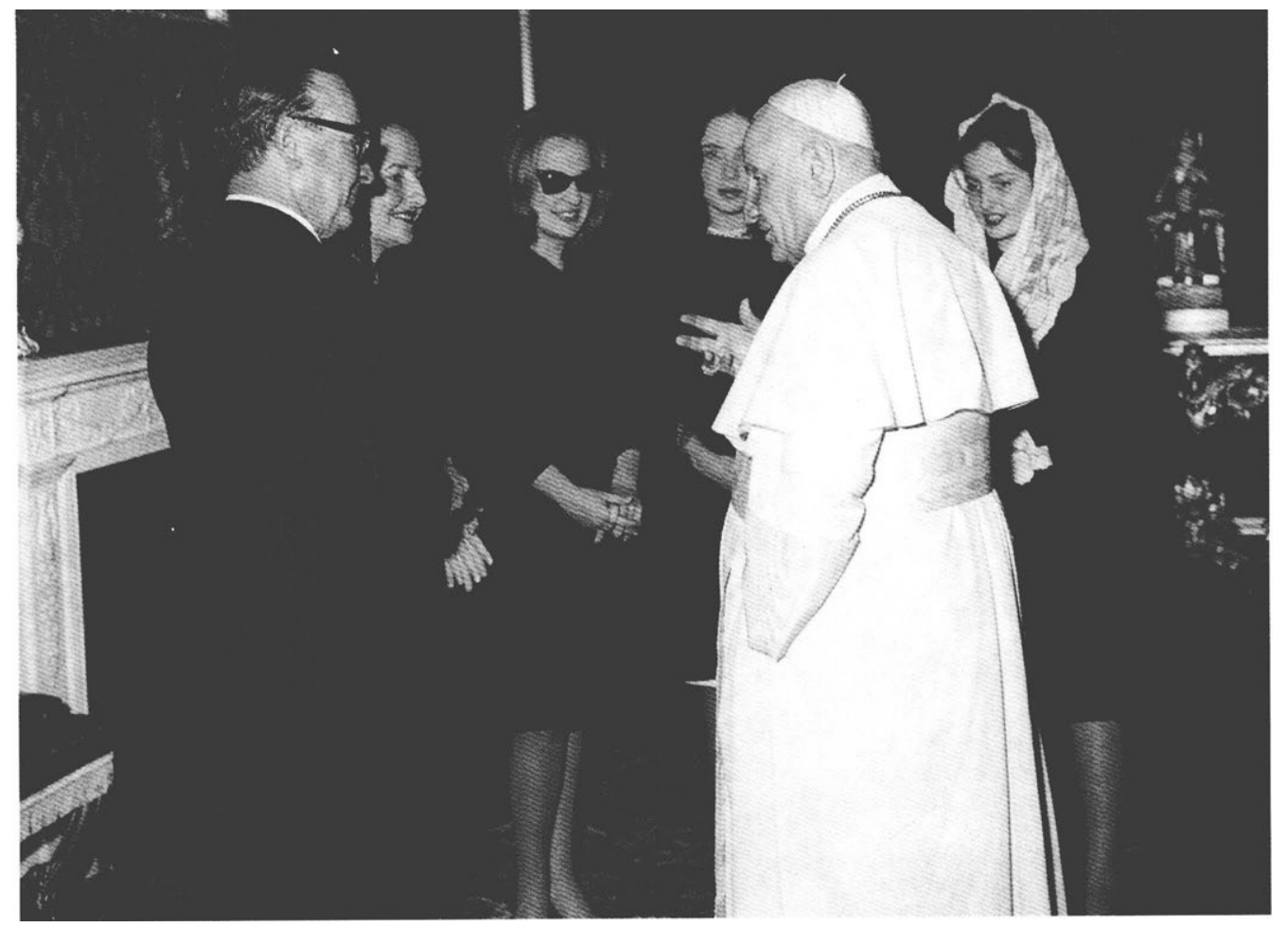

A fantilia, con audiência particular com João XXIIl. Carlos Chagas Filho, dona Annah, Anna Margarida, Maria da Clória e Cristina [zabel, 1963

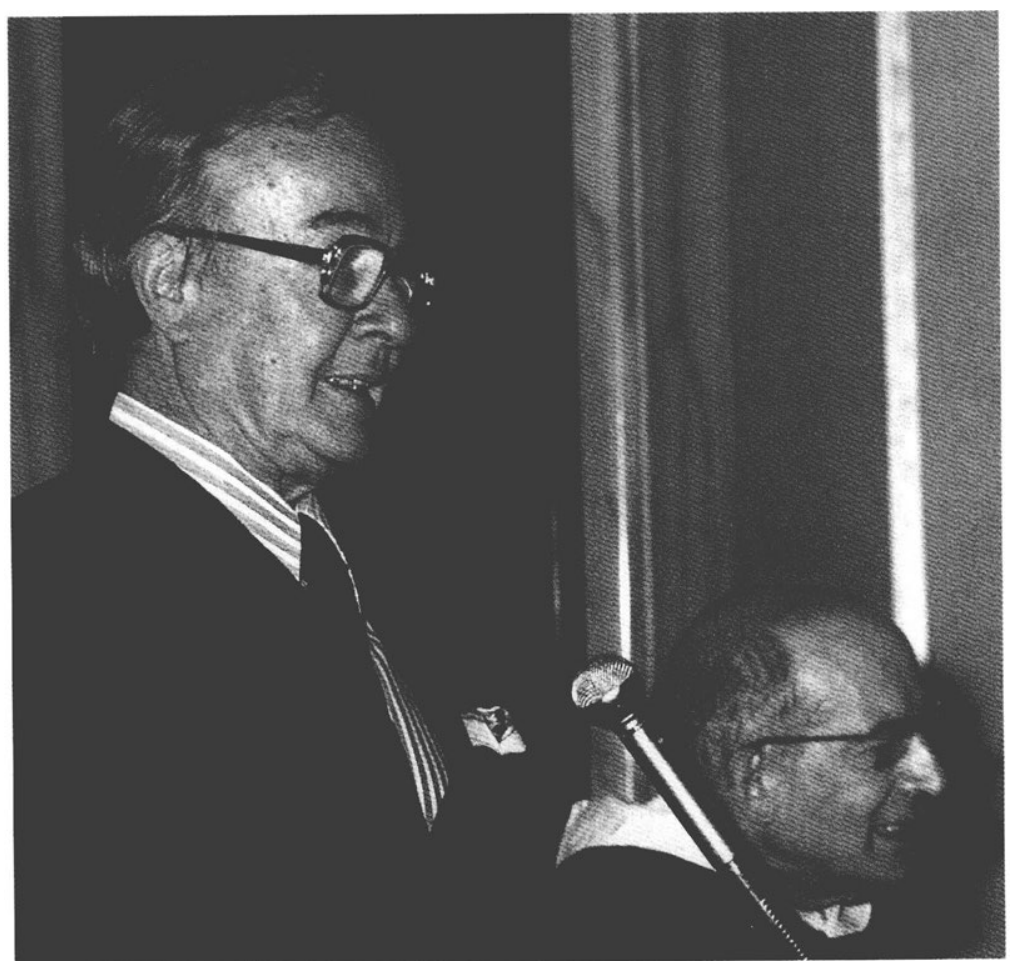

Com o patre Enrico di Rovasenda. chanceler da Academia Pontificia de Ciencias

(1972-1986). "() que ganthei com sta convivência indescritivel. Fitivel. altamente intelectual, timha o bumanismo $c$ o liberalismo como características de seu pensamento, sempre de una fe inamovivel" (Marini-Betrolo, C. B. L'Atrivitá della Pontificia Aciademia delle Scinze, 19361986. Pontificiae Academiac Scientiarum Scripta Varia, n. 71. MCMLXXXVII, p. 47, cortesia da APC) 


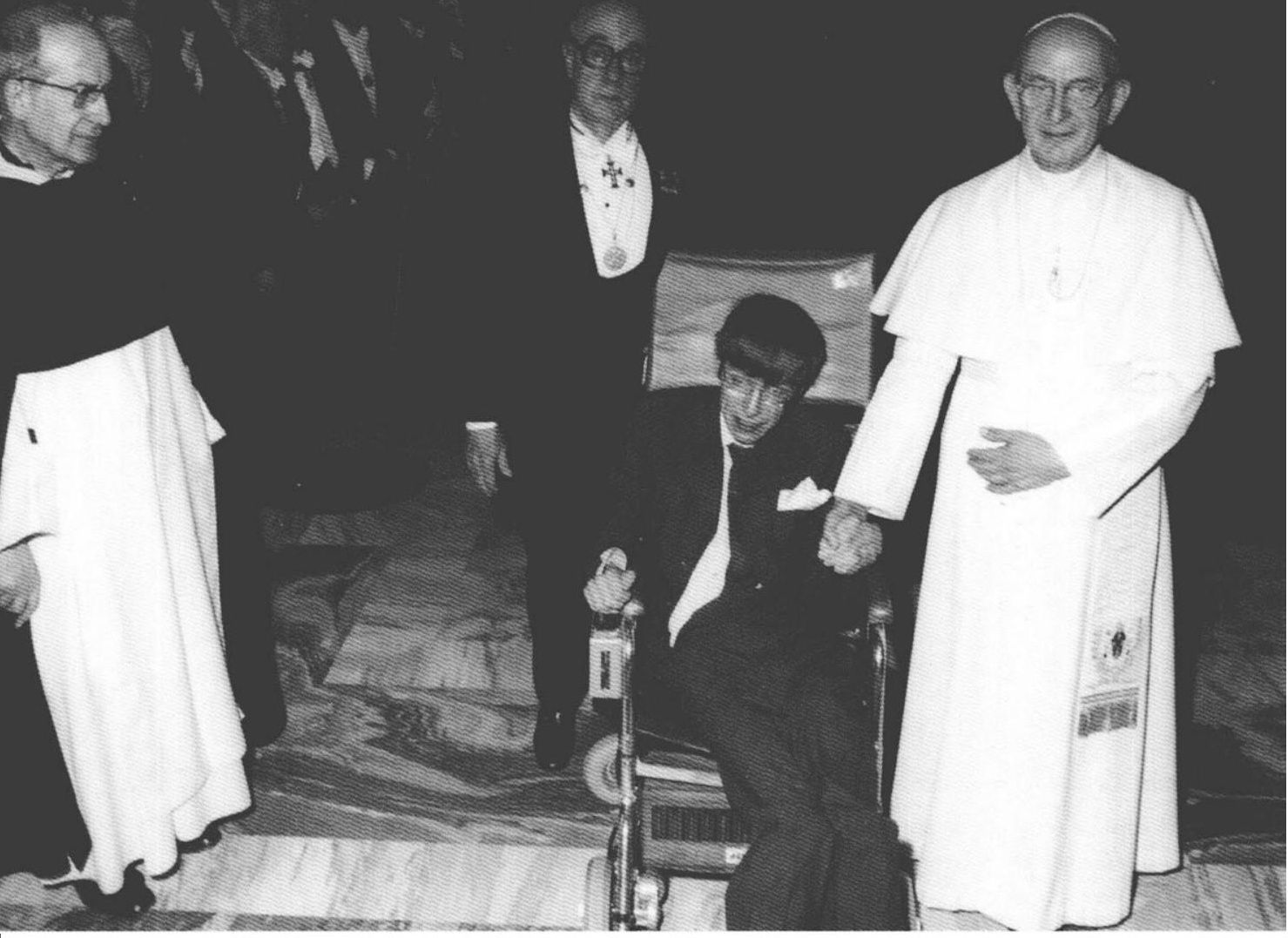

Paulo VI e Carlos Chagas Filho acompanham Stephen Hawking, observados pelo padre Enrico di Rovasenda. após concessào da Medalha Pio XI ao cientista, 1975 (Marini-Bettòlo, op. cit., p. 51. cortesia da $A P C$ )

Joìo Paulo 11 prounncia discurso sobre Einstein c Galilew durante audiencia na Academia Pontificia de Ciencias, 10 de novembro de 1979

(Mariai-Bettolo, op. cit., p. 65, cortesia da $\mathrm{AP}^{\mathrm{P} C}$ )

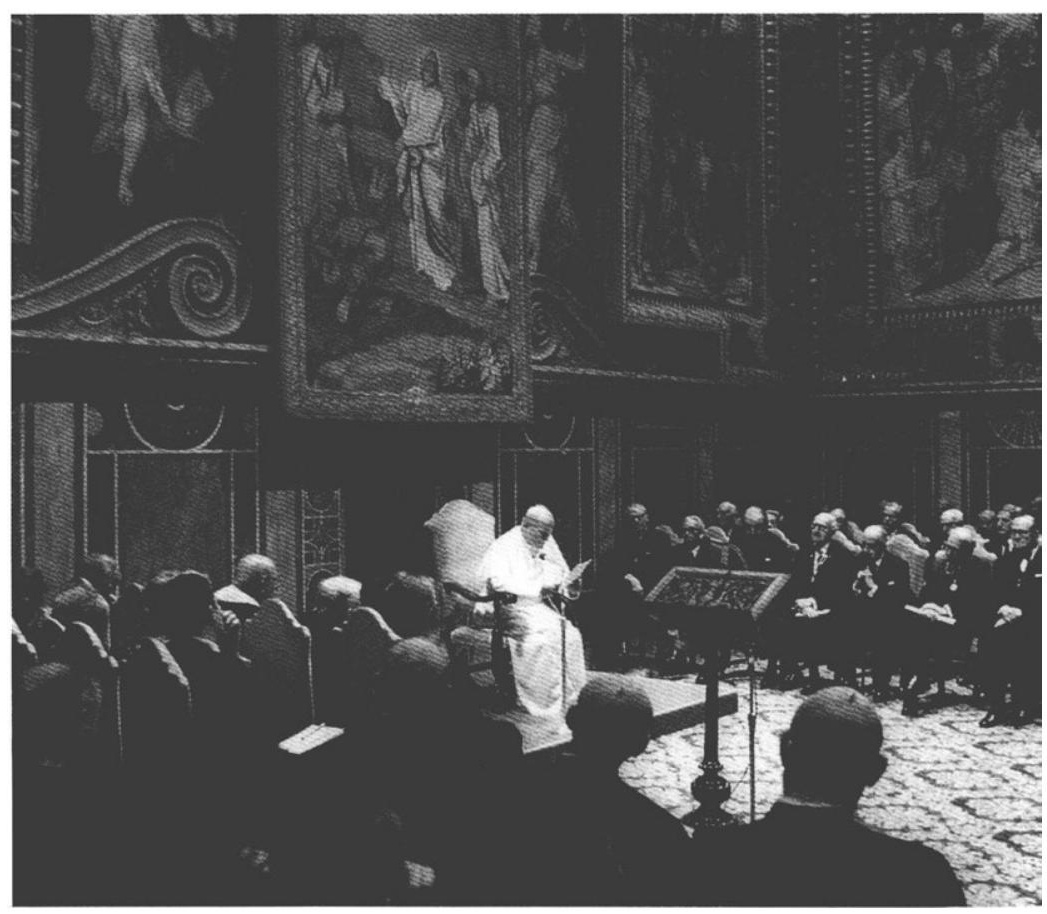




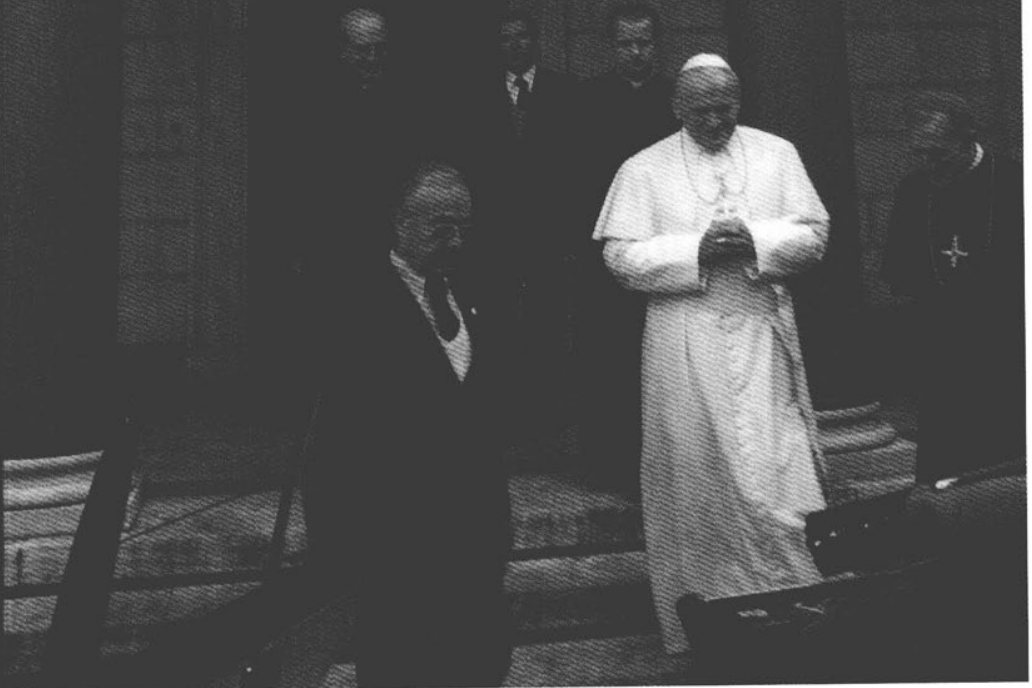

Carlos Chagas

Filho e

Joàc Paulo II deixam a Casina

Pio IV após a leitura do documento

Dedaration on Prevention of Nindear itiar. Ao fundo, padre Enrico di Rovasenda. 1982 (cortesia Al'C)

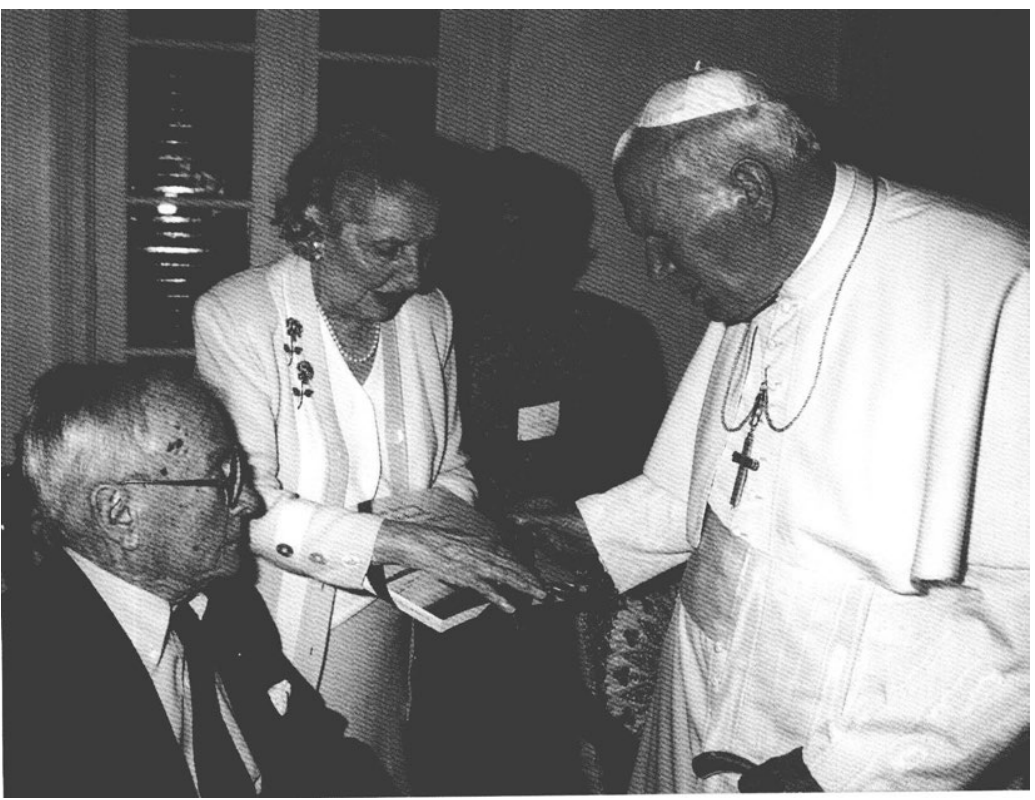

O casal Carlos Chaggas Filho oferece a João Paulo Il o álbum $A$ cioncia a cominho da rogn, editado pela Casa de Oswaldo Cruz/ fiocruz. Rio de Janeiro, 1998 


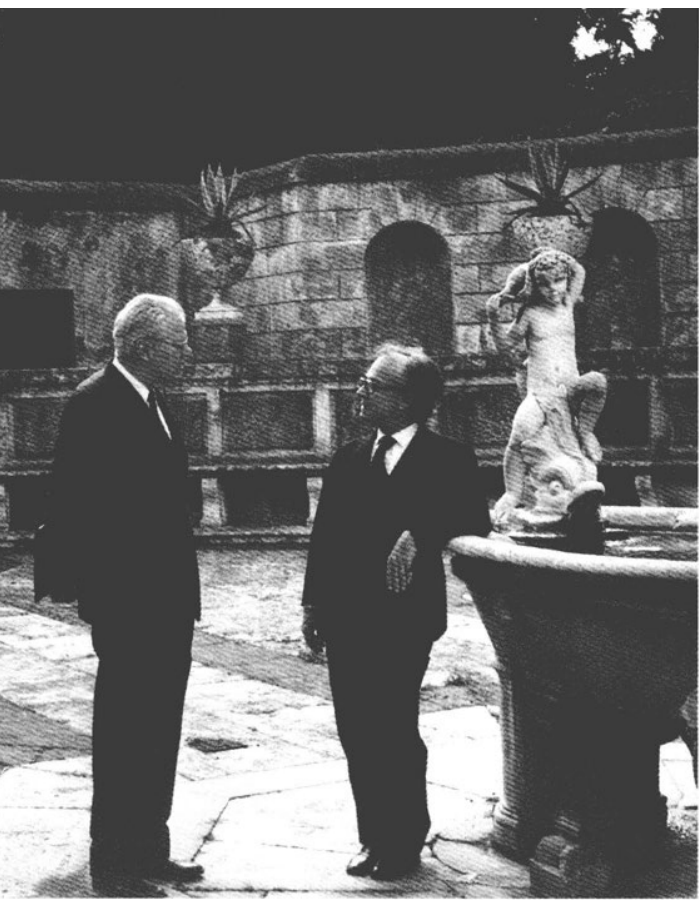

Carkos Chagas Filho com Marini-Bettolo. conselheiro que participou da feitura do documento contra a guerra nuclear eo substituiu na presidencia da Academia Pontificia de Ciéncias. P'átio da Casina

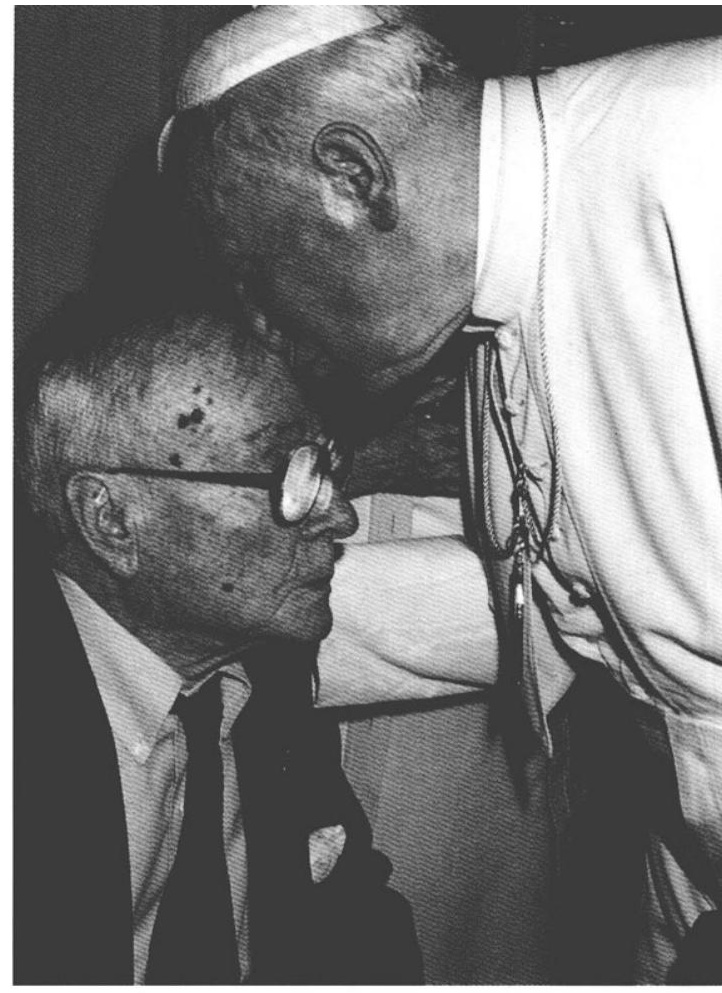
l'jo IV, s./d.

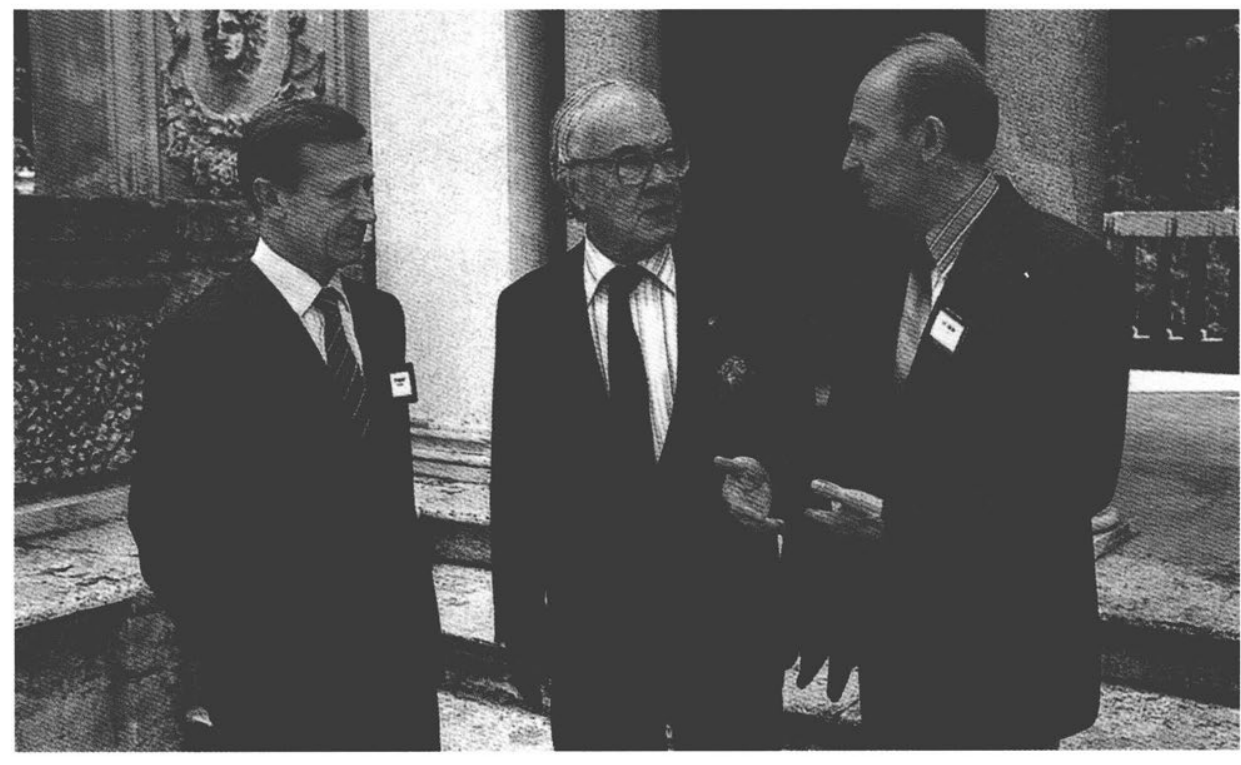

Abertura na Academia Pontificia de Cièncias: Youri Kholosov (à esq.), enviado pessoal de Mikhail Gorbachev e Anatoll Shutko, nembro da Acadenia de Ciências Soviética durante sessão da APC, 24 de janeiro de 1977 


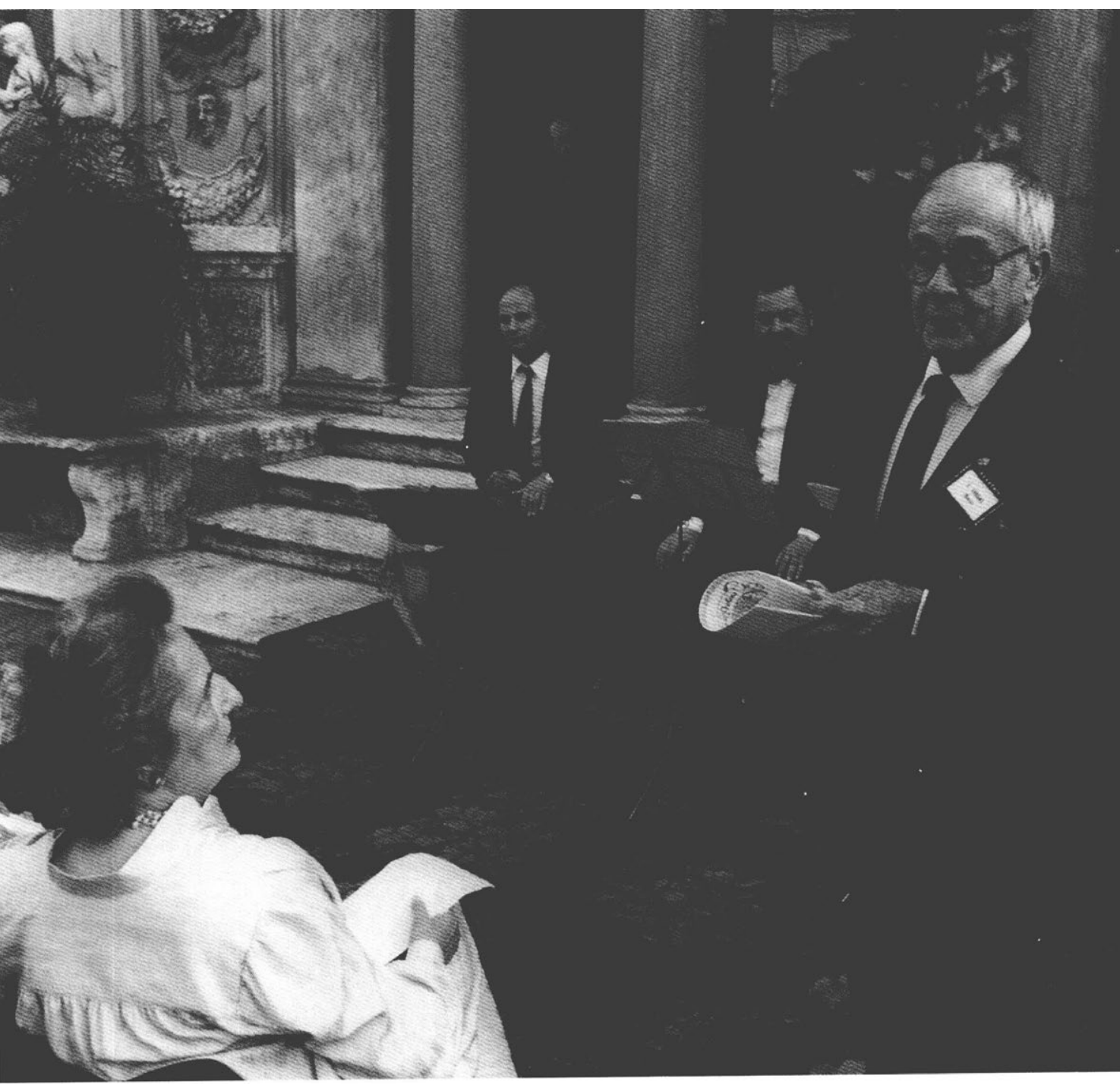

Amante da música, apresenta concerto na Casina Pio IV com doma Annah em primeiro plano, s./d. 
Casal Carlos Chagas

Filho com Jorge

Amado, Roma, dexembro de 1976

Dorival Caymmi

em saralu na

residencia do

Autor. dezembro de 1906
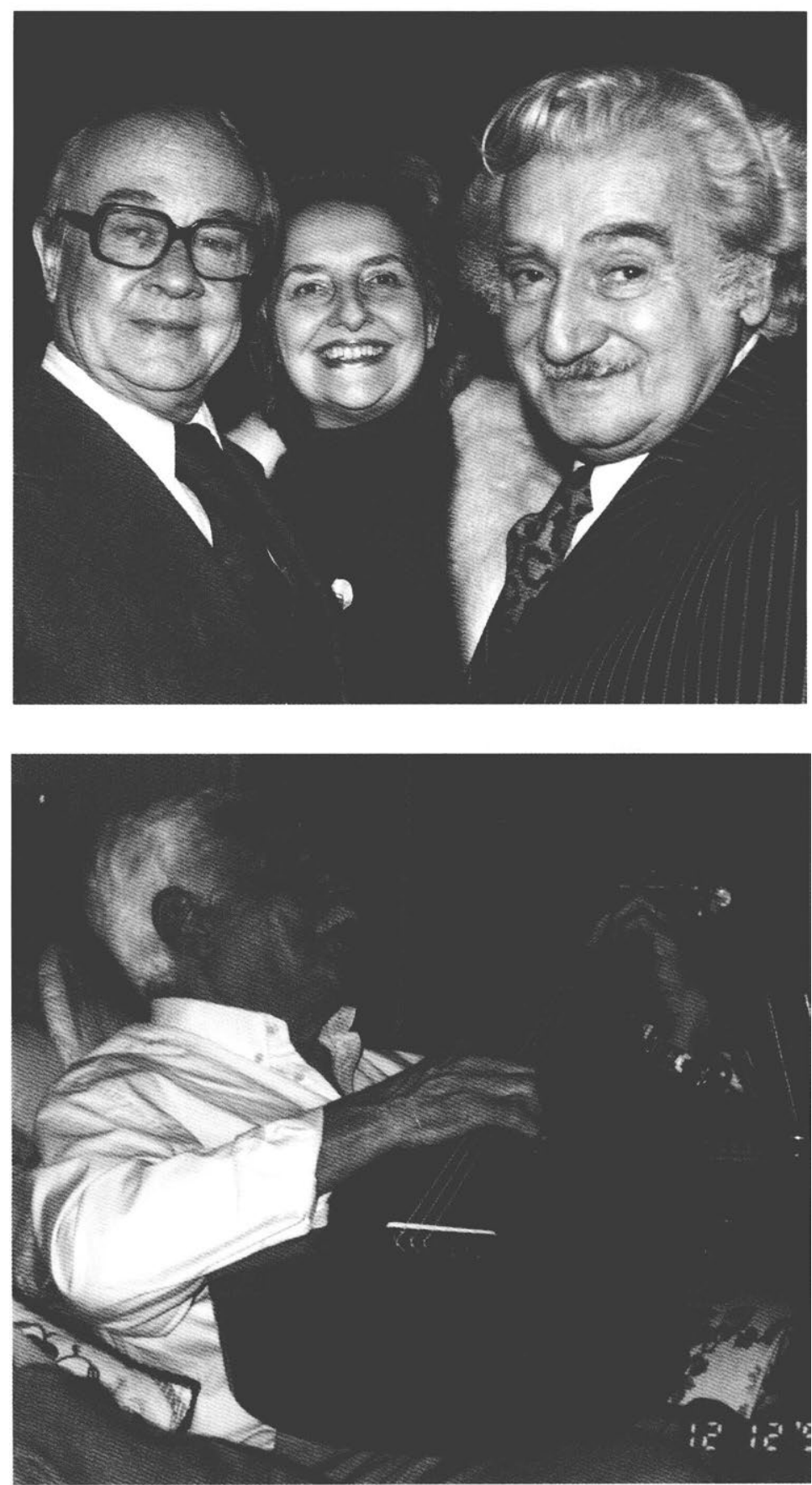


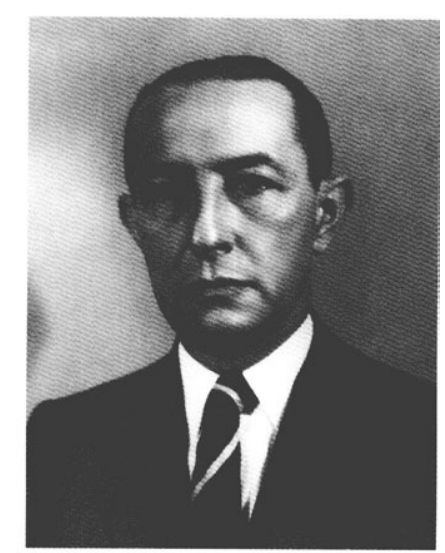

Virgílio de Mello Franco, irm.jo de doma Ammah. "Varão sem tenores esem defeitos gue, como os jequitibas do vale do Jequitinhonha, derrubados pela gemancia de madeireiros, foi abatido por uma bala traçocira, decisando o mundo mais pobre" (dedicatória do livro Comatos e contrabonatos. editado pela $C O C$. Fiocruz), decada de 1940

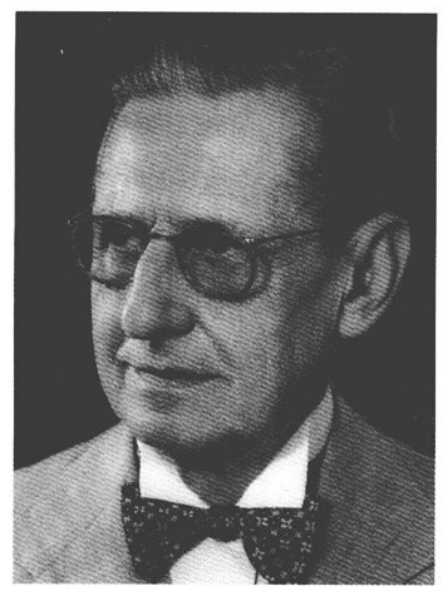

Guilherme (iunle, patrono da ciencia. apoiou com entusiamo o) Serviço de Estudo das Grandes Endemias, de Evandro Chagas, e a criaçio do Instituto de Biofísica: "O oferecinento de Guilherme Guinle era a garantia de que eu poderia pesquisar na Universidade" (cortesia de Maria Cecilia de Paula Machado), 1960

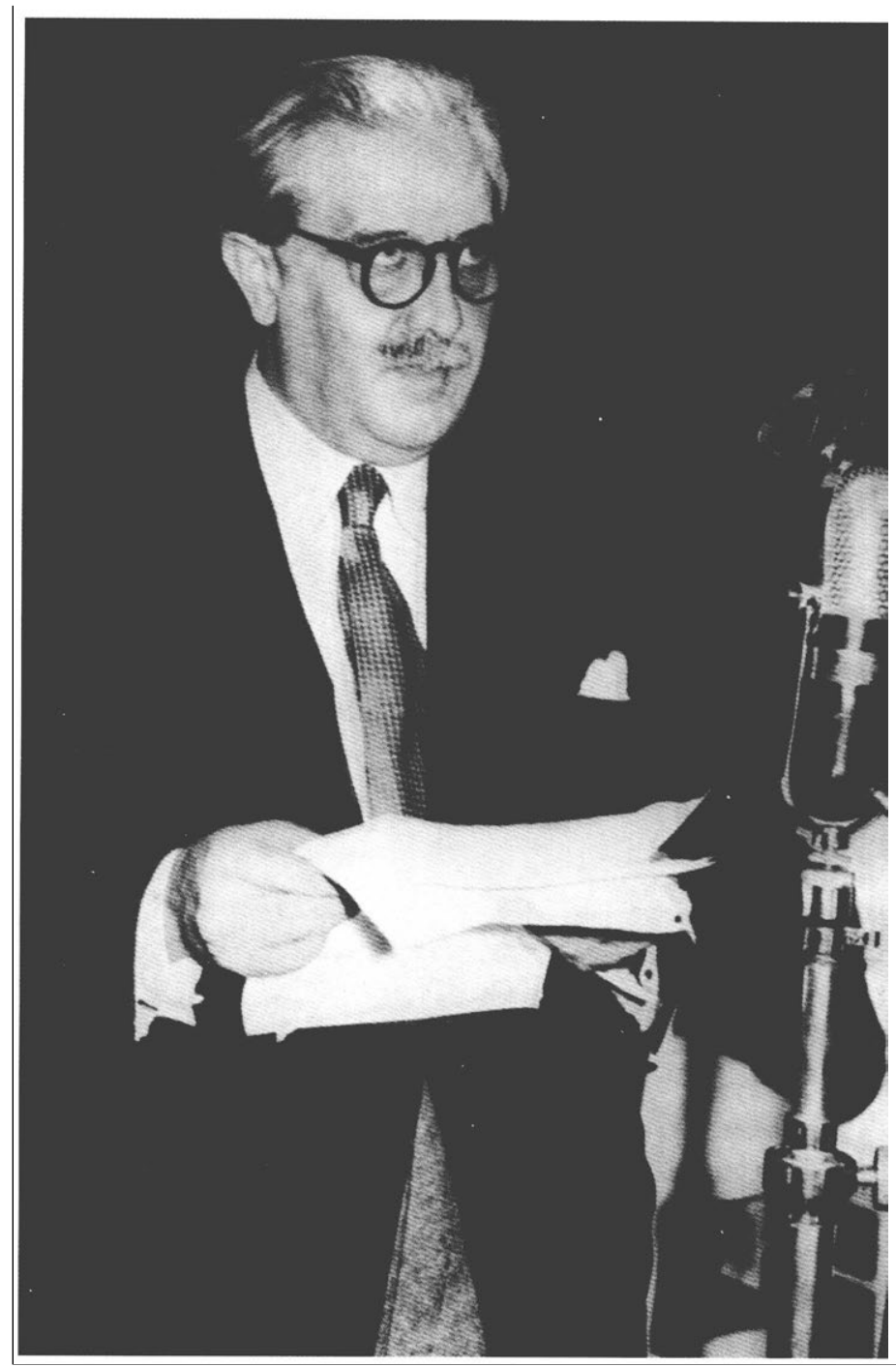

Georges Bernanos, intelectual de grande influchncia na formação católica de Carlos Chagas Filho: "escritor que trazia a poesia na alma e ardor do combate pela boa causa no coraçào, deu-me uma nova concepção de igreja, muito mais livre c compreensiva" (Milner, Max, George's Bermanos, Paris, 1)esclie e Brouwcr, 1967, p. 272) 
Álvaro Alberto, ao centro, dá posse ao professor Joaquim da Costa Ribeiro, à dir., como diretor científico do CNPq. Costa Ribeiro, "um dos mais nobres homens que encontrei na vida", participou da preparação de

Carlos Chagas Filho para o concurso de cátedra, 1951
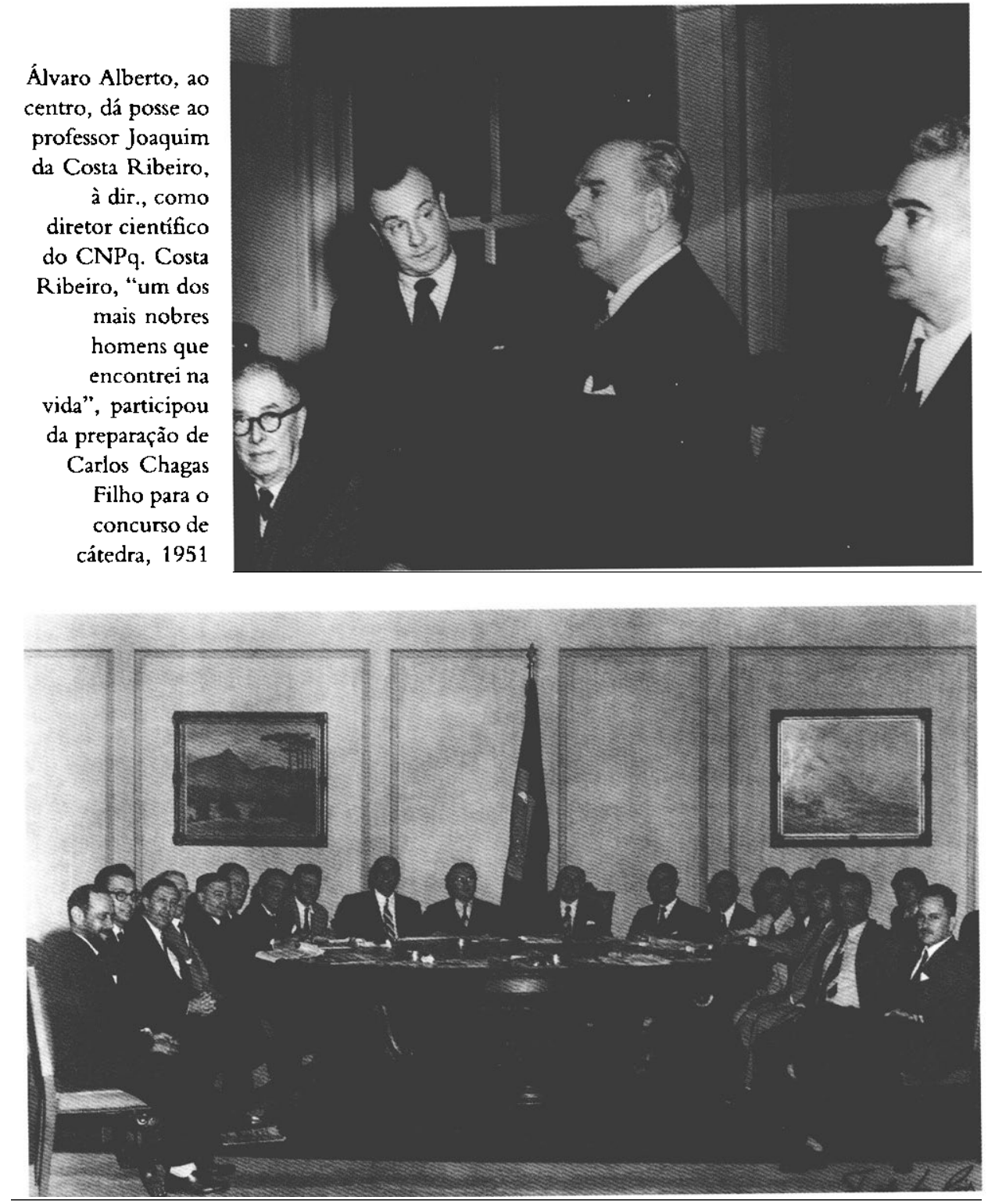

Posse do Conselho Deliberativo do CNPq. "Nunca será suficiente assinalar o que representou, para o progresso de nosso país, a presença de Álvaro Alberto, sem o qual os primeiros passos do CNPq teriam sido por demais lentos e não teriarn a eficiência que tiveram", 17 de abril de 1951 (cortesia do CNPq). Da esq. para a dir.: Sylvio Torres, Edmundo Pena Barbosa da Silva, Heitor Grillo, Alvaro Ozorio de Almeida, Olympio Oliveira Ribeiro da Fonseca Filho, Lelio Itapuameyra Gama, Luiz de Barros Freire, Cesar Lattes, Orlando da Fonseca Rangel Sobrinho, Armando Dubos Ferreira, Alvaro Humberto da Motta e Silva, Arizio Vianna, Arthur Moses, Joaquim da Costa Ribeiro, Francisco de Sá Lessa Filho, Alvaro Deffini, José Baptista Pereira, Marco Abrantes da Silva Pinto, Aécio de Albuquerque Antunes, Diamantina Ferreira da Cunha. 


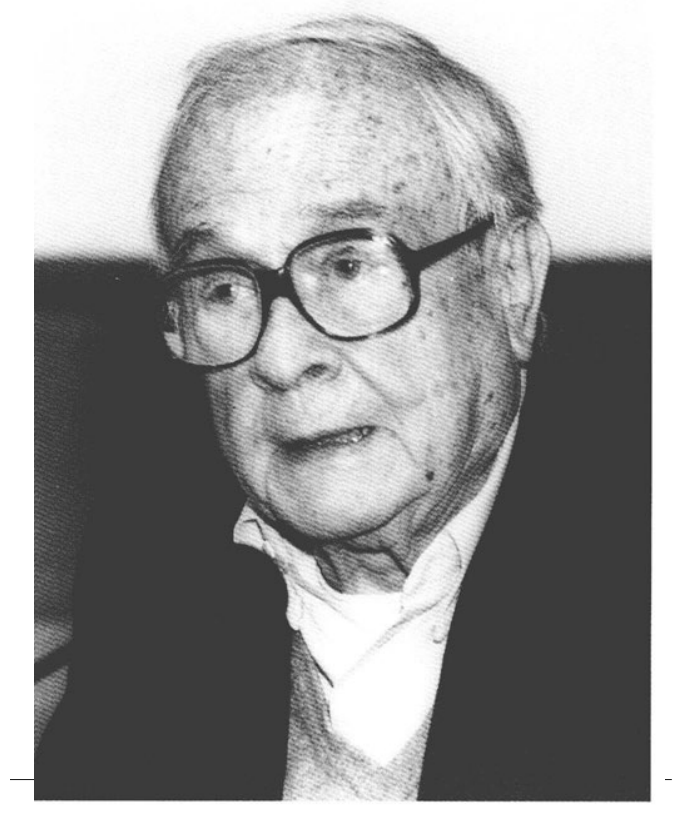

\section{Nota biográfica}

Nasceu em 12 de setembro de 1910, Rio de Janeiro, filho de Carlos Ribeiro Justiniano Chagas ( Iris Lobo Chagas e cinco anos mais moço do que seu único imão Evandro Chagas. Realizou seus primeiros estudos no Curso Lyra e no Colégio Rezende. Matriculou-se na Faculdade Nacional de Medicina da Universidade do Brasil em $1926 \mathrm{e}$, no segundo ano médico, trabalhou no Hospital São Francisco e no Instituto de Manguinhos, onde fez sua iniciação científica. Recebeu, em 1931, a Medalha Antonia Chaves Berchon des Essarts, concedida ao aluno com as melhores notas no decurso dos seis anos de Faculdade. Completou sua formação clínica em estágios, nos anos 1930 e 1931, dirigindo o Hospital de Lassance, mantido pelo Instituto de Manguinhos, na terra onde seu pai descobrira a doença de Chagas. Casouse em 1935 com Anna Leopoldina Cesario Alvim de Mello Franco, tendo quatro filhas: Maria da Glória, Silvia Amélia, Anna Margarida e Cristina Izabel.

Em 1932, prestou concurso para a livre-docência de fisica biológica e passou a assistente na Faculdade de Medicina. Em 1937, assumiu o cargo de professor titular de fisica biológica, por concurso. Trabalhou com René Wumser e Alfred Fessard, em Paris, e A.V. Hill, na Inglaterra. Ao retornar, fazendo prevalecer seu lema "A universidade é um local onde se ensina porque se pesquisa”, dedicou-se à organização de un grupo de pesquisadores para o laboratório de biofisica. En 1945, o laboratório transformou-se no Instituto de Biofisica, centro de estudos de renome internacional. Desde a fundação do CNPq (1951), participou ativamente do seu Conselho Deliberativo. Foi delegado do Brasil na I Conferência Geral da Unesco e na segunda, em Paris e na cidade do México, respectivamente. Em seguida, foi convidado para o 
Comitê de Pesquisa da Organização Pan-Americana de Saúde, nele atuando até 1962. Em 1963, organizou, como secretário especial, a $1^{\text {a }}$ Conferência das Nações Unidas para a Aplicação da Ciência e Tecnologia ao Desenvolvimento. Recebeu o título de Doutor em Ciência da Universidade de Paris. Em consequiência dos sucessos obtidos, foi nomeado presidente do Comitê Especial das Nações Unidas para Aplicação da Ciência e da Tecnologia, função que exerceu por seis anos, fundando, junto com Abdus Salam e outros, a Academia do Terceiro Mundo. Em 1966, foi nomeado embaixador do Brasil junto à Unesco. Eleito presidente da Academia Brasileira de Ciências (1965 a 1967), retomou, em 1970, a direção do Instituto de Biofisica, que passou a levar seu nome.

Em 1972, Carlos Chagas foi nomeado pelo papa Paulo VI presidente da Academia Pontificia de Ciências, cargo que exerceu durante dezesseis anos. Organizou notadamente o processo de reabilitação de Galileu Galilei pela Igreja, foi o artífice do documento da Igreja contra a guerra nuclear, promoveu a datação do Santo Sudário e a aproximação da fé e da ciência.

Recebeu dezesseis títulos de Doutor Honoris Causa em universidades nacionais e estrangeiras e dezenove condecorações, entre as quais a de Comendador da Ordre Nationale de la Légion d’Honneur (França, 1979). Foi eleito, em 1974, para a Academia Brasileira de Letras. Membro, entre outras academias científicas, da Académie des Sciences de l'Institut de France, recebeu, pelo conjunto de sua obra científica, oito prêmios, entre os quais o Prêmio Fundação Moinho Santista (1960), o Prêmio Alvaro Alberto para Ciência e Tecnologia (CNPq, 1988), o Prêmio Alfred Jurzykowski (Academia Nacional de Medicina, 1978) e o Prix Mondial Cino del Duca (1989, Paris). Foi admitido, em 1994, na Ordem Nacional do Mérito Científico, na classe de Grã-Cruz, e em 1999 recebeu a Medalha Oswaldo Cruz e o Prêmio Personalidade da Ciência do Rio de Janeiro pela Fundação de Amparo à Ciência do Estado do Rio de Janeiro (Faperj), que hoje leva seu nome.

Faleceu em 16 de fevereiro de 2000. 
Este livro foi impresso em São Paulo, em maio de 2000, pela Lis Gráfica e Editora, para a Editora Nova Fronteira e a Editora Fiocruz.

O tipo usado no miolo foi Bembo 12/15.

O papel do miolo é offset $75 \mathrm{~g} / \mathrm{m}^{2}$, o do caderno de fotos é couché matt $120 \mathrm{~g} / \mathrm{m}^{2}$ e o da capa é cartão $250 \mathrm{~g} / \mathrm{m}^{2}$.

Atendemos pelo reembolso postal.

EDITORA NOVA FRONTEIRA S.A.

Rua Bambina, 25 - Botafogo - 22251-050 - Rio de Janeiro - RJ

Não encontrando nossos títulos em livrarias, contactar a EDITORA FIOCRUZ.

Rua Leopoldo Bulhões, 1.480, térreo - Manguinhos

Rio de Janeiro, RJ. CEP: 21041-210

Tels.: (21) 598-2701 e 598-2700

Telefax: (21) 598-2509 e 598-2700 